( $)$

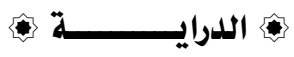

\title{
جائز الحديث عند الإمام العجلي ودلالته دراسة مقارنة
}

الدكتور

هبلد حسيز حسيز حسشز

مدرس الحلديث وعلومه بكلية أصول الدين بالثاهرة 
$(r)$

جائز الحديث عند الإمام العجلي ودلالته 


\section{ملخص البحث}

تطرقت في بحثي المى مصطلح "جائز الحديث" بعند الإمام العجلي

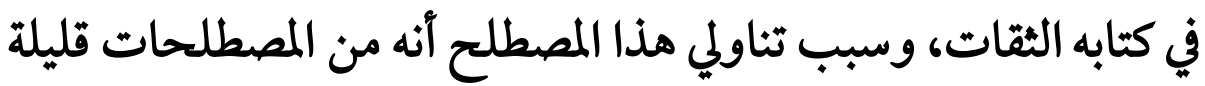

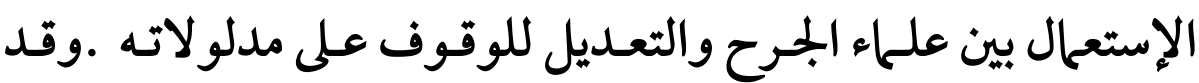

توصلنا الى أن الإمام العجلي قد سبق في استخدامه لمذا المصطلح، ولحئ وهو

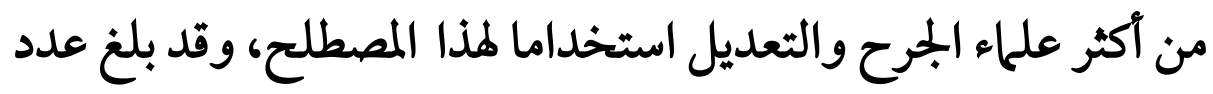

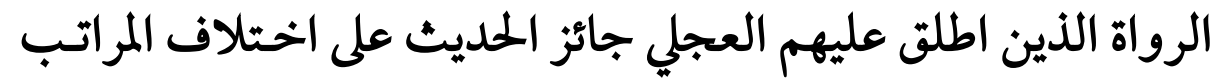

$$
\text { أحد عشر راويا من المجموع الكلي للرواة. }
$$

In this research, we refer to the term " Jaes $E$ Hadeth" in the book of Imam al-'Ajli, The reason we deal with this term is that Few terms used among wound scientists and modification, We have concluded that the Imam al-Ajli has already used this term, which is one of the most scientists GARACH AND TEA the use of this term, The number of narrators who were called al-Ajlai is permissible to talk about the difference in rank of eleven narrators from the total number of narrators. 
الحمد الله رب العالمين وآفضل الصلاة وآتم التسليم على سيدنا محمد وعلى آله وأصحابه الطيبين الطاهرين، وعلى من سار على خطاهم واتبع سنتهم إلى يوم الدين، وبعد:

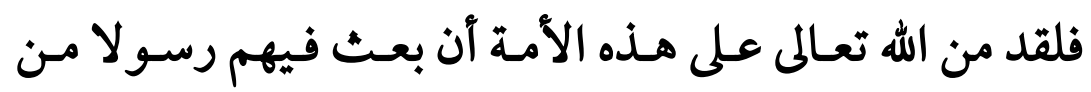

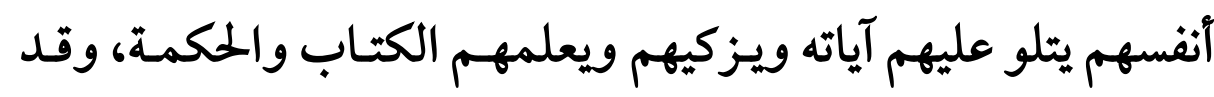

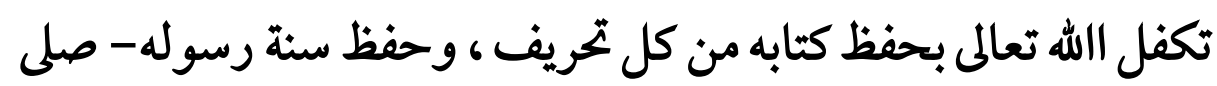

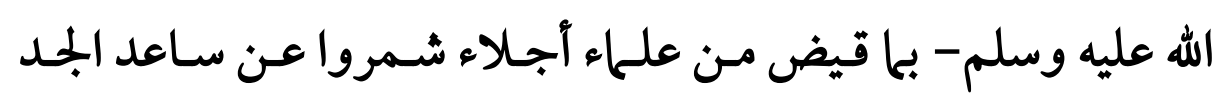

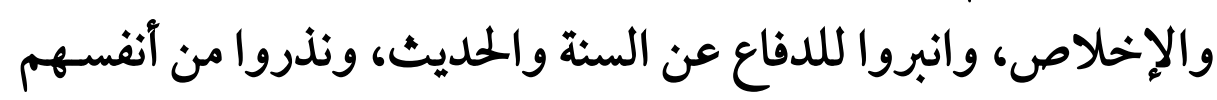

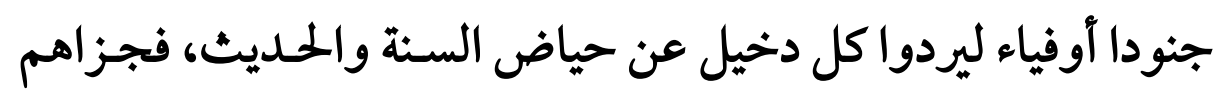
الله خير الجززاء.

ومن العلم)ء الذين كانت لهم أياد بيضاء في خدمة السنة النبوية -

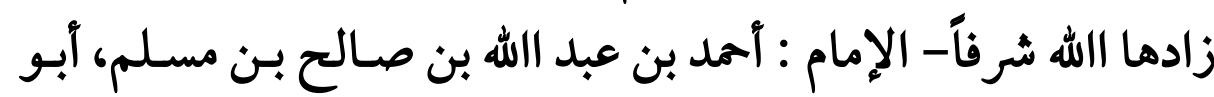

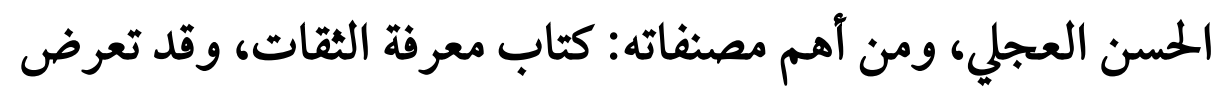

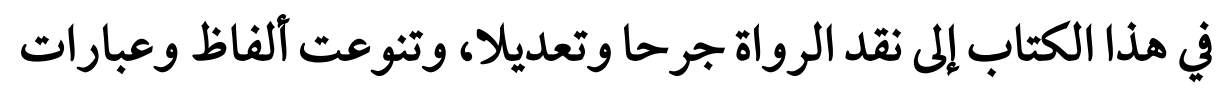

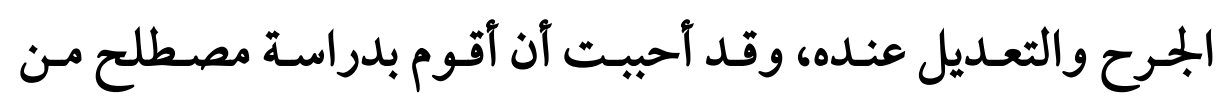

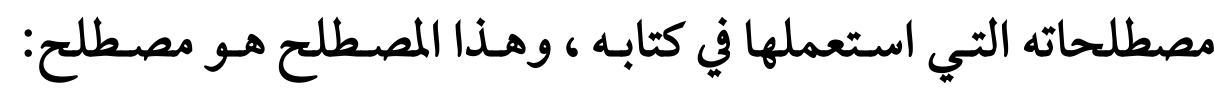

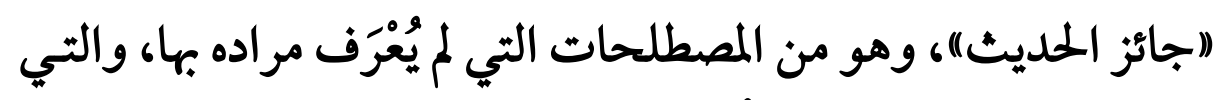

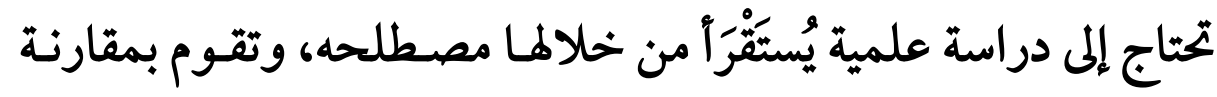

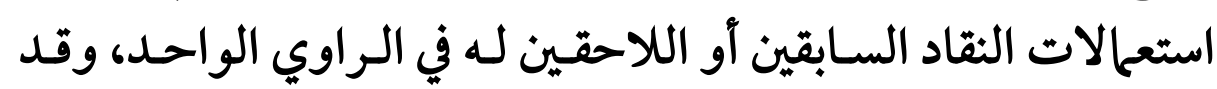


قمت باسقراء (اثثات العجلي")، واستخراج كل راو وصفه العجلي بأنه

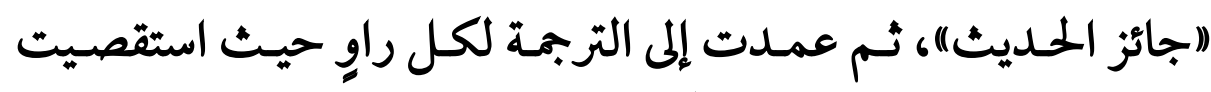

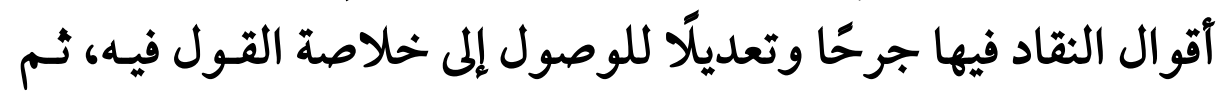

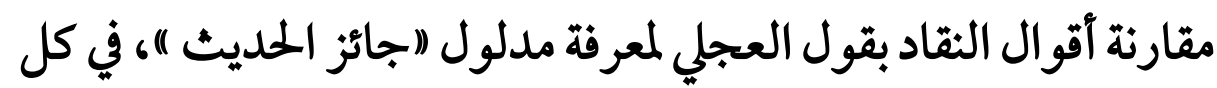
راو من رواة هذا البحث.

\section{أهمية البحث ودوافع اختياره:}

تكمن أهبية البحث فيما يلي:

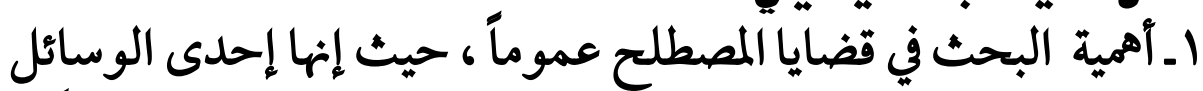

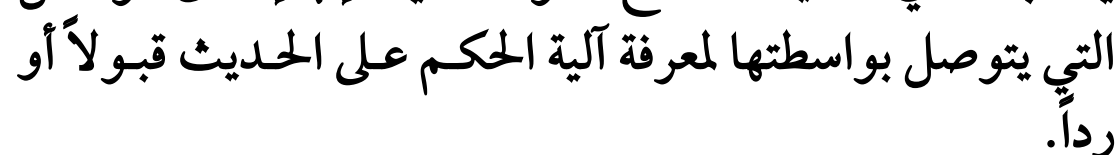

Y ـ الوقوف على مفهوم ومـدلول هـذا المصطلح عند الإمـام العجلي،

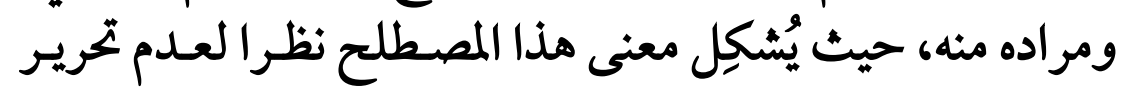

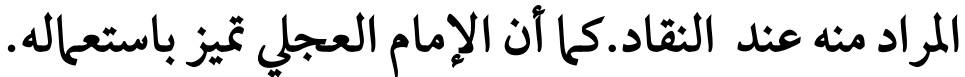

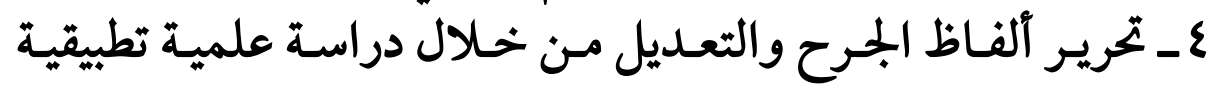

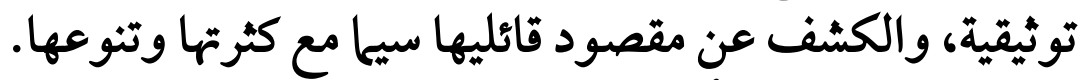

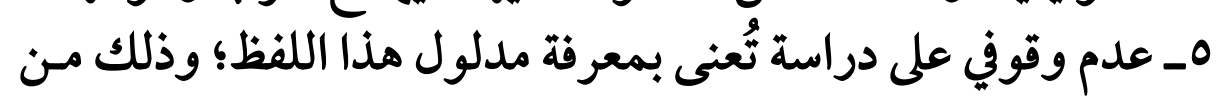
خلال ما اطلعت عليه من مصادر.

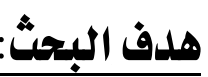

يهدف الباحث من خلال هذه الدراسة إلى الوقوف على مقصود

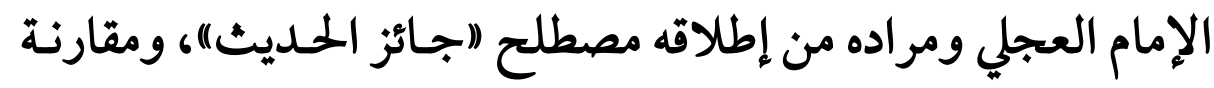
مدلول هذا المصطلح عنده مع غيره من النقاد. 
(ฯ)

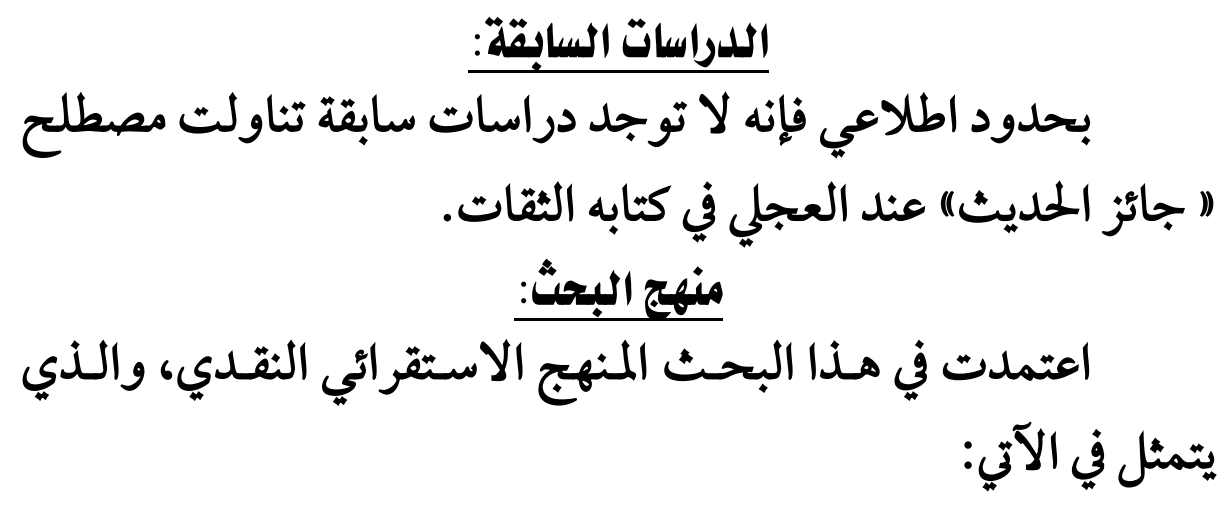
ا ـ قمت باستقراء كتاب ((معرفة الثقات))، لجمع الرواة الذين قال فيهم الإمام العجلي - رحمه الله: (جائز الحديث)".

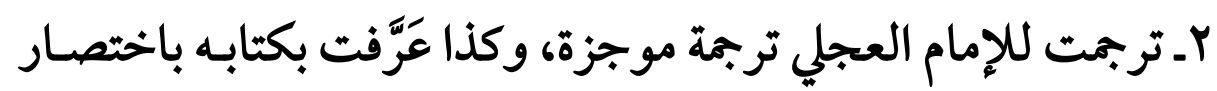
من خلال الكتب المتخصصة في ذلك. rـ قمت باستقراء آقوال النقاد الآخرين في الراوي الذي الذي وصفه العجلي بذلك الوصف (الراوي موضع البحث). عـ نقلت الرواة بحسب تريبهم في كتاب: ((معرفة الثقات))، للإمـام العجلي، وهو مرتب على حروف المعجم.

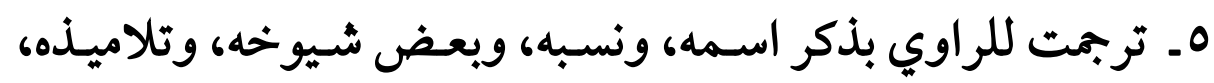
وأقوال النقاد فيه، ووفاته. 7ـ ترجمت للرواة ترجمة وافية بحسب ما اطلعت عليه من كتب التراجم

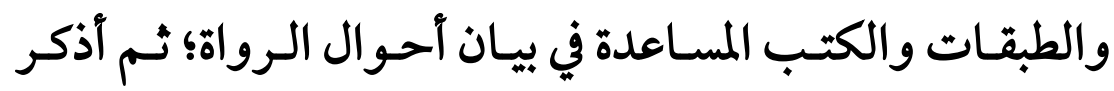
خلاصتها حسب رأي أكثر العلهاء ومحققيهم جمعـا أو ترجيحـا

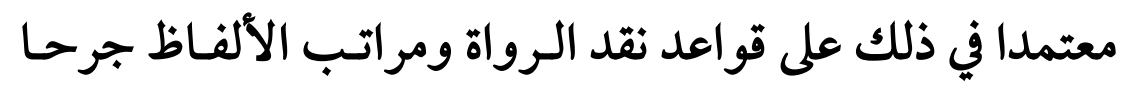


(v)

وتعديلا مع الإحالة على المصادر المعتبرة في ذلك من كتب الرجال وغيرها.

ثم ذكر القرائن التي تسـاعد على الوقـوف على مـدلول عبـارة الإمـام

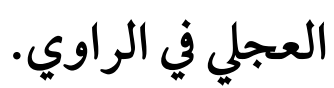

Vـ اقتصر-ت عـلى ذكر اسـم الكتـاب، والجـزءء، والصـفحة، وبـاقي التعريف بالكتاب، ذكرته في قائمة المصادر والمراجع للاختصار. ^ـ ختمت الترجمة بذكر مثال تطبيقي لحديث مروي بإسناد فيه الراوي موضع البحث، وحكم إمام عليه إن وجـد، مـع الحكـم إن كـان خارج الصحيحين.

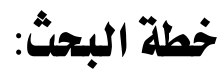

ينقسم البحث إلى مقدمة، وقسمين، وخاتمة، وفهرس:

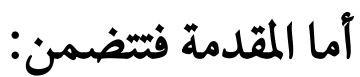

$$
\text { أهمية الموضوع، وأسباب اختياره. }
$$

القسه الأول: اللدراسة النظرية: وتتكوز من مبحثين:

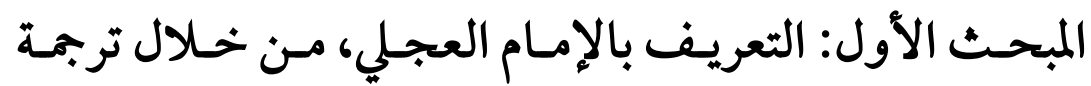

موجزة له تشتمل على المطالب الآتية:

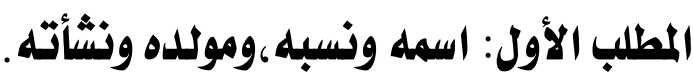

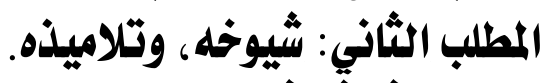

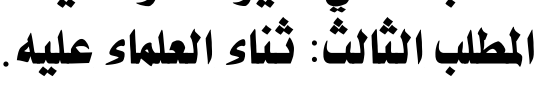
المطلب الرابع:مؤلفاته ،ووفاته. 
$(\wedge)$ جائز الحديث عند الإمام العجلي ودلالته

المبحث الثاني: التعريف بكتاب 》معرفة الثقات)، للإمام المجلي، وقد

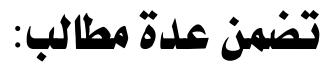
المطلب الأول: تخقيق القول في اسم المئ الكتاب.

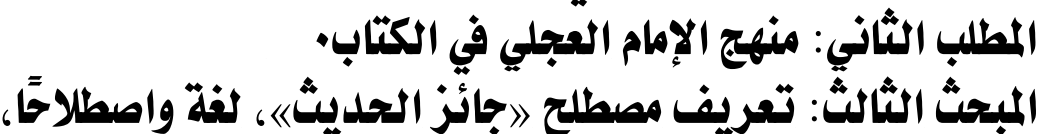
واستعمالات الإمام العجلي لهاته

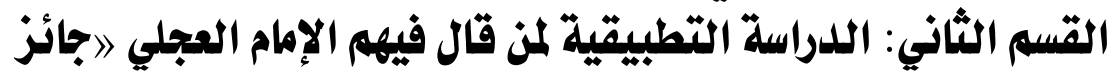

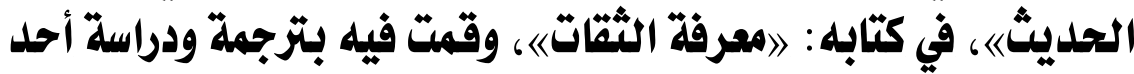
عشر راويا قدل وصفوا بذنك. الخاثمة وأهم النتائج والتوصيات. الفهارس. الباحث: د/عيد حسن حسن حسن

مدرس الحديث وعلومه بكلية أصول الدين بالقاهرة 
(9)

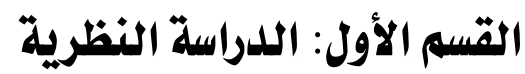

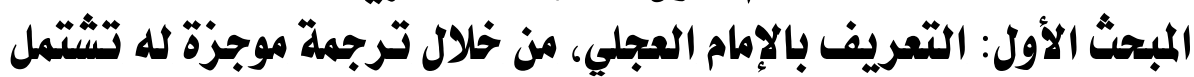

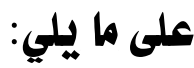
المطلب الأول: : اسمه ونسبه،ومولده ونشأته.

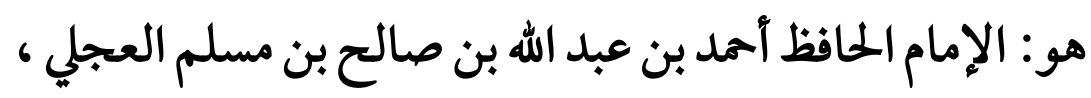
أبو الحسن الكوفي الأصل.

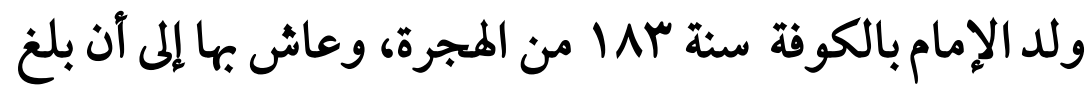

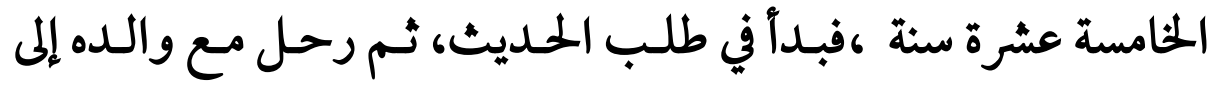
بغداد سنة ا بـ من المجرة فسمع من علمائها.

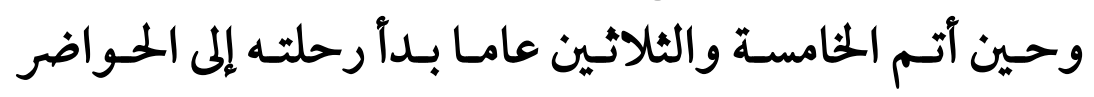

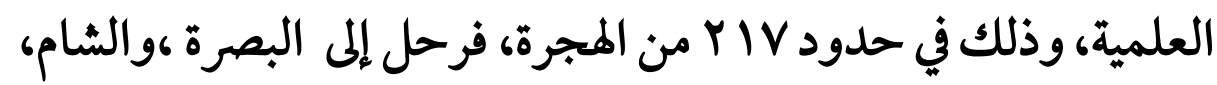

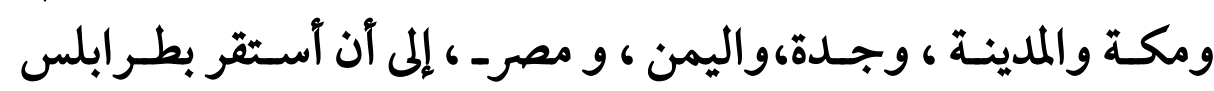
المغرب فجعلها مستقرا له رغبة في التفرد للعبادة وبعدا عن الفتن. (1). المطلب الثاني: شيوخه، وتلاميذه.

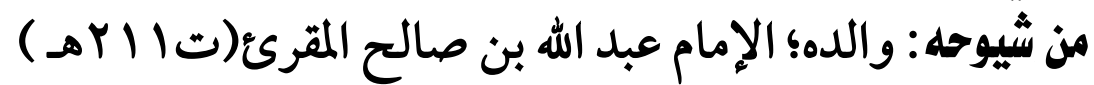

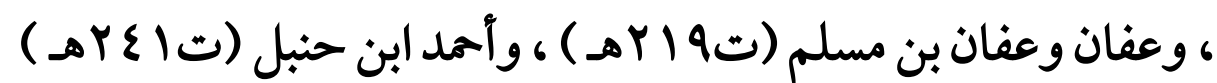
، و يميى بن معين (ت بسץ وعـ ) ، وغيرهم. 


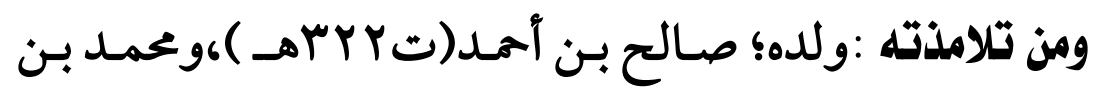

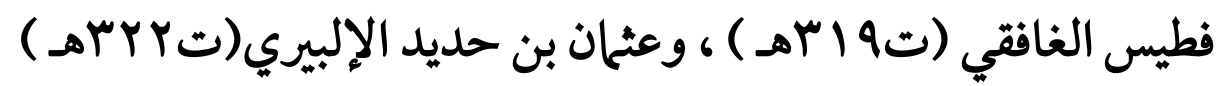
وغيرهم - وفيسن

قال الإمام الذهبي: ولم أظفر بحديث من روايته. (1).

المطلب الثالث: ثناء العلماء عليه.

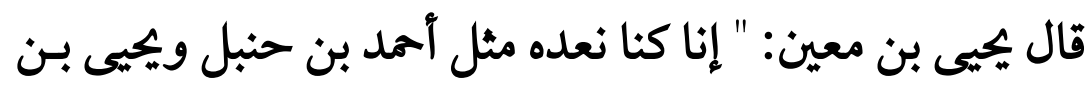

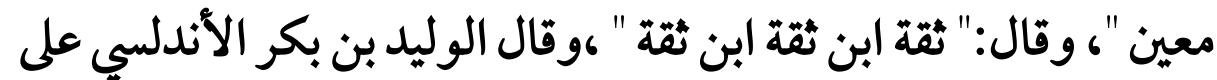

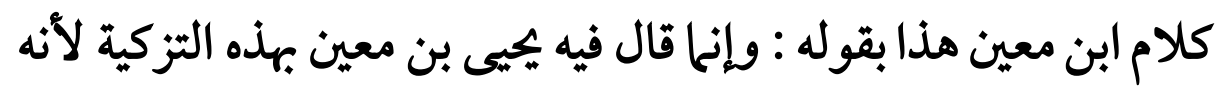

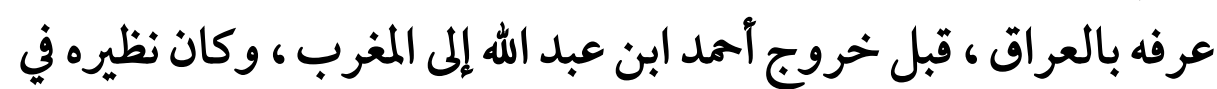

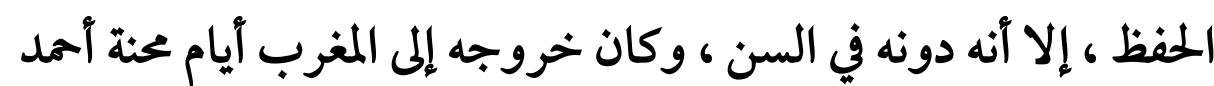

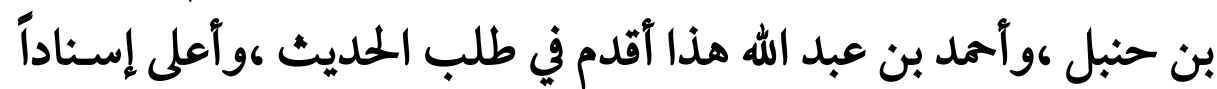

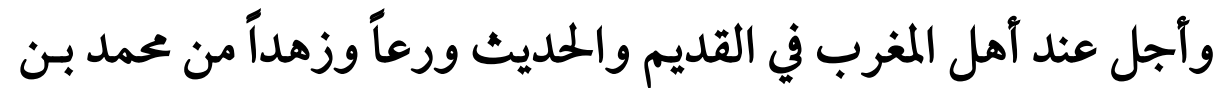

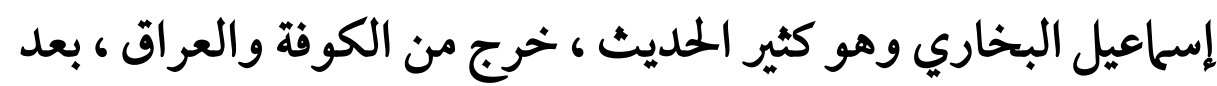
أن تفقه في الحديث (r). وقال الذهبي: " الإمام الحافظ الأوحد الزاهد "(r).

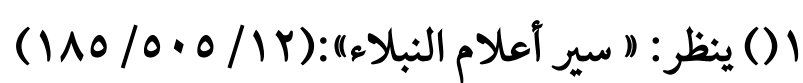

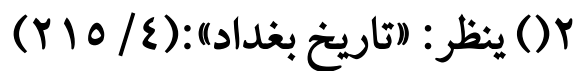

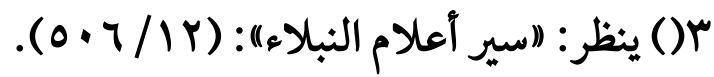


وقال ابن ناصر الدين الدمشقي : " كان إماماً ، حافظاً ، قدوة ،

من المتقنين وكان يعد كأحمد بن حنبل ويجيى بن معين "(1). المطلب الرابع:مؤلفاته ،ووفاته.

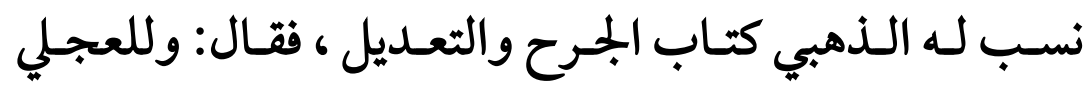

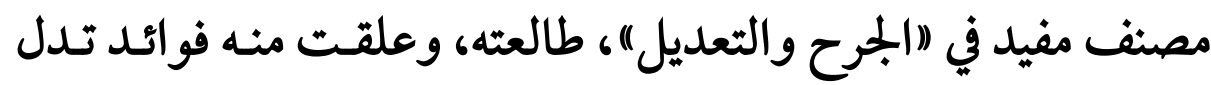
على تبحره بالصنعة، وسعة حفظه (r). وساق الحافظ ابن حجر إسناده إلى إلى

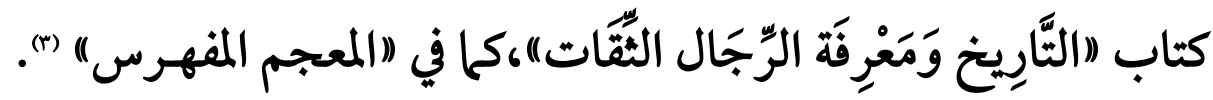

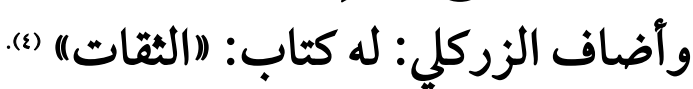
وكل هذه الأسهاء هي لكتاب واحد كما سنتعرض له له عند تحرير

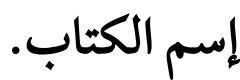
ـ وفاته. توفي الإمام العجلي بطرابلس المغرب، سنة (آY هـ ) عن تسع وسبعين سنة . ذكر آَبوُ سَعِيد بْن يونس المصري أنه مات فِي سنة إحدى وستين ومثُتين (0).

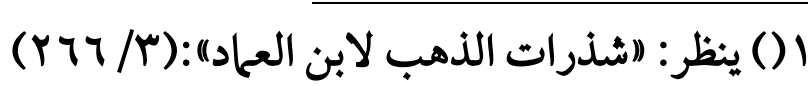

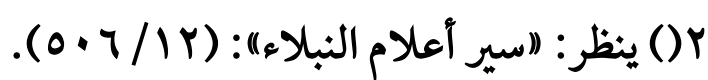

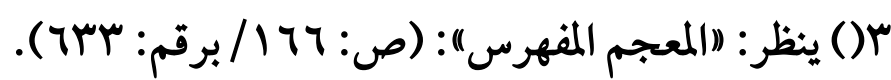

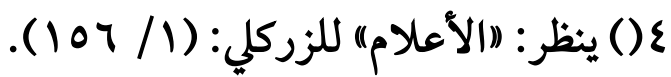

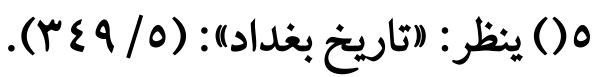


(Ir) جائز الحديث عند الإمام العجلي ودلالته

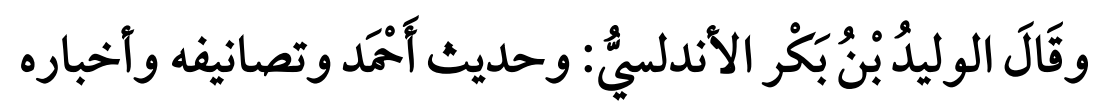

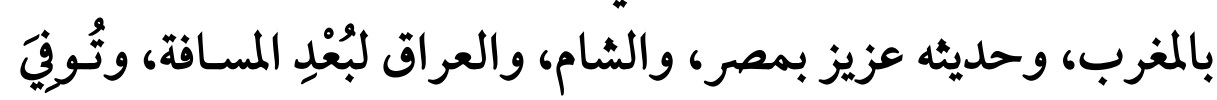
بأطرابلس المغرب، فقبره هناك على الساحل، وقبر ابنه صالح إلمَّى جنبه (1).

(() ينظر: (التاريخ بغداد): (1) (Y/0)، (اقلادة النحر في وفيات أعيان الدهر): . (T.T/Y) 
المبحث الثاني: التعريف بكتاب 》معرفة الثقاته)، للإمام المجلي: المطلب الأول: تحقيق القول في اسم الكتاب:

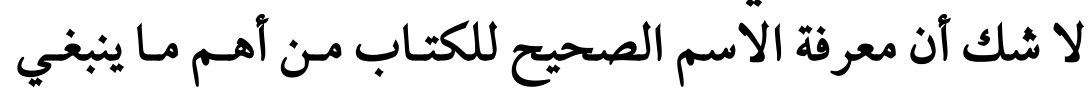

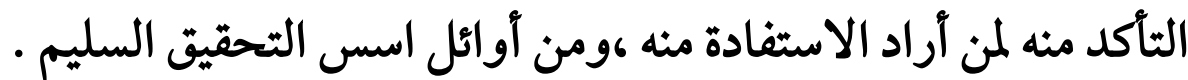

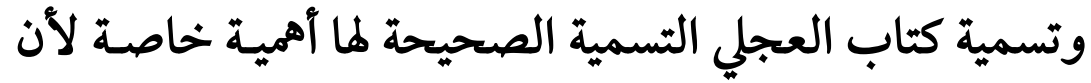

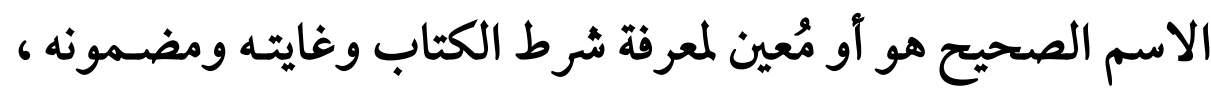

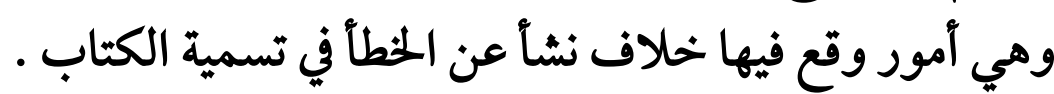
وقد طبع ترتيب كتاب العجلي عدة طبعات :

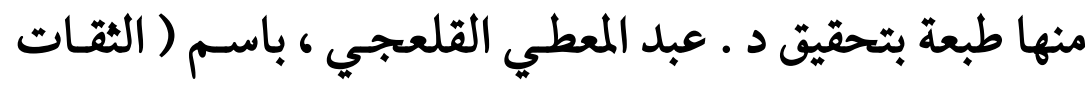

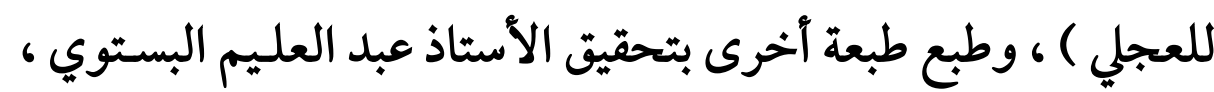

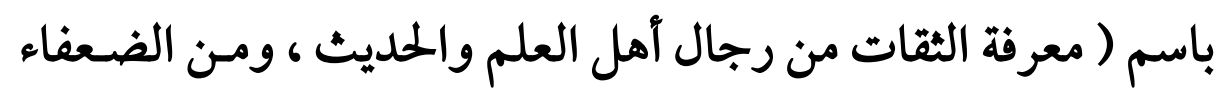

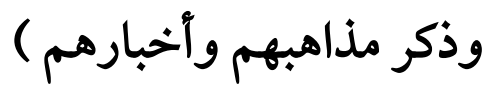
اـ "الثقات" كحا يفهم من نسخة الإمام الميثمي للترتيب فقـد في

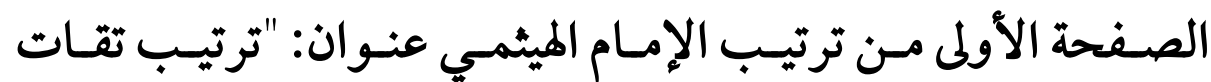

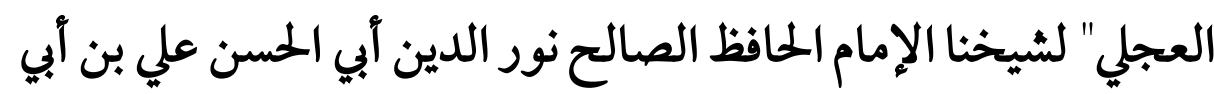
بكر بن سليهان الميثمي...الخ. rـ "كتاب سؤالات أبي مسلم صالح أباه أبا الحسن أحمد بن ء بـ بلد اللها

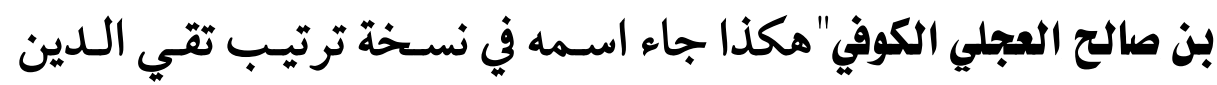


rـ "كتاب الجرح والتعديل" وصفه بذلك: الإمام الذهبي.(1)

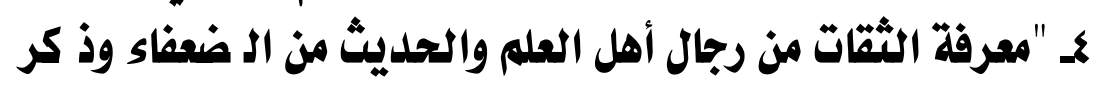

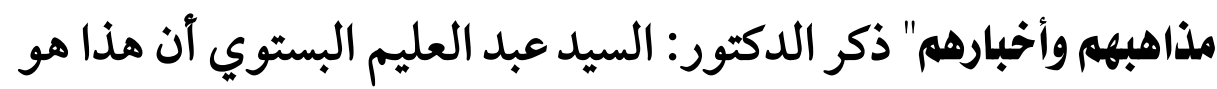

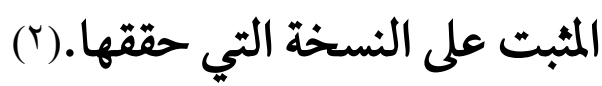

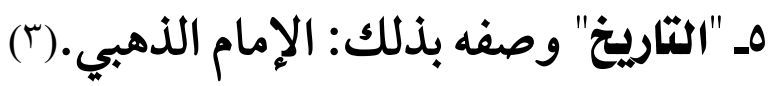

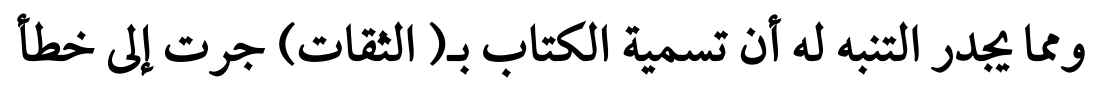

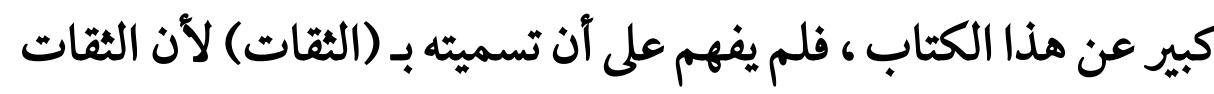

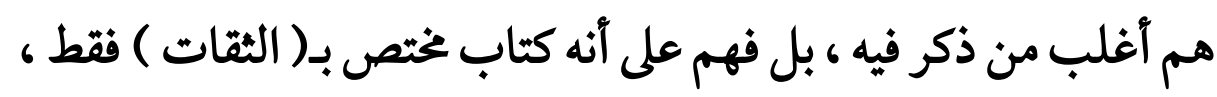

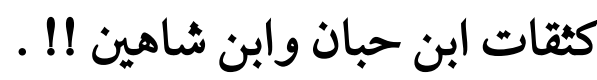

فمن الحفاظ : يقول خاتمتهم الحافظ ابن حجر في ( نزهة النظر )

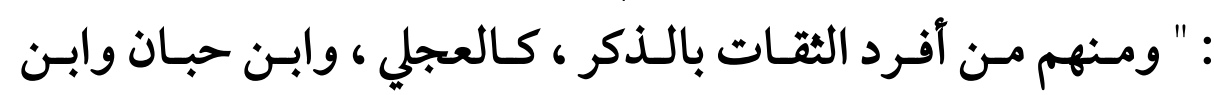

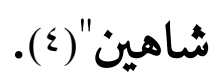
ومن المعاصرين : يقول فضيلة العلامة الأستاذ الدكتور آكرم

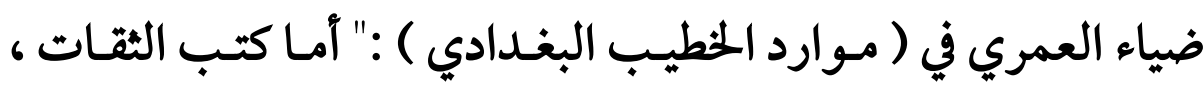

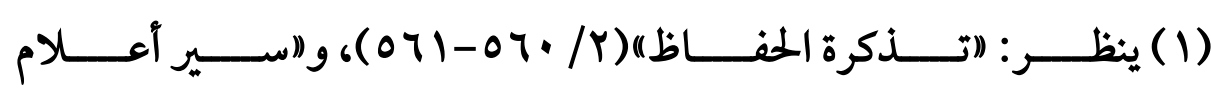

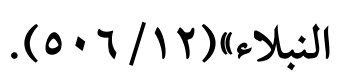

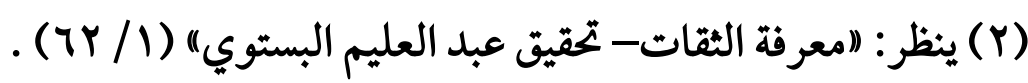

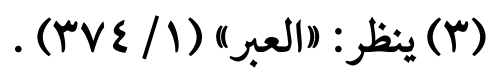

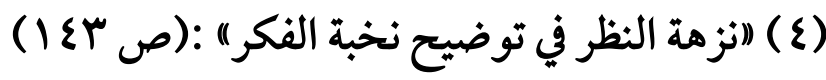


فأول من صنف فيها : أبو الحسن أحمد ابن عبد الله بن صالح العجلي

إلا أن الصواب : أن كتاب العجلي ليس مختصاً بـ الثقات ) ففيه

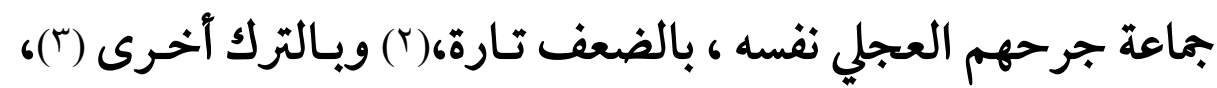

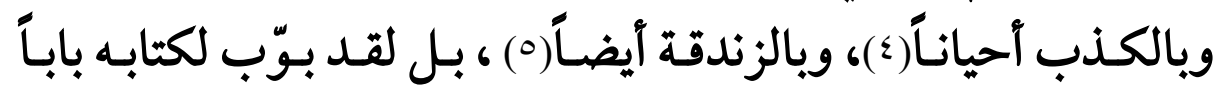

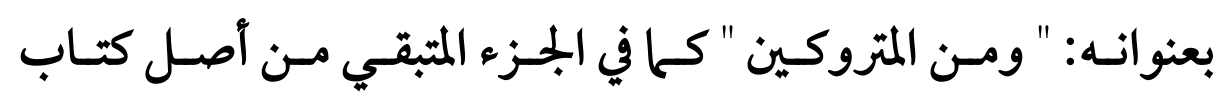

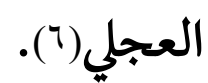

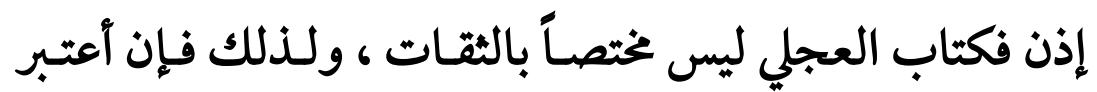

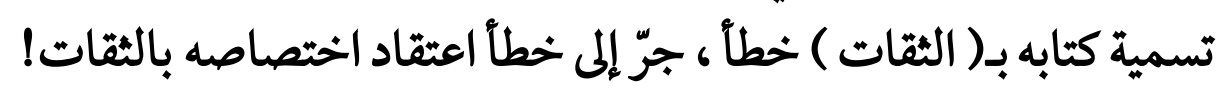

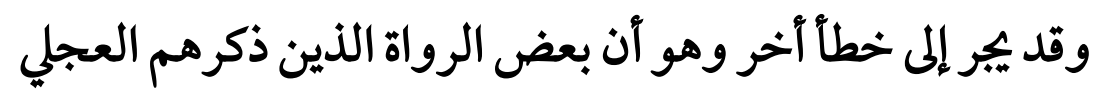

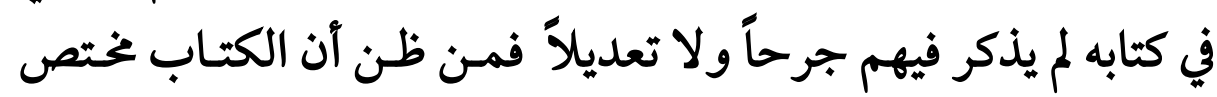

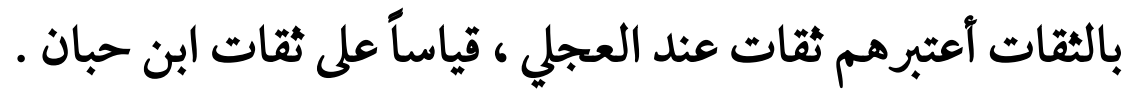

$$
\text { (1) (اموارد الخطيب للعمري)( (ص الب) . }
$$

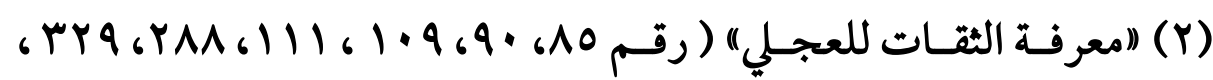
(ITYE، OT76rYq

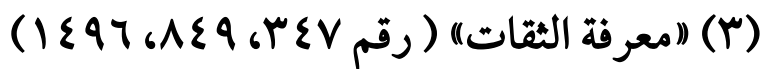

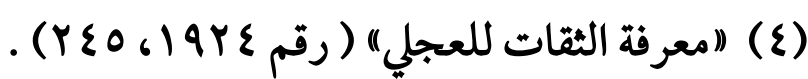

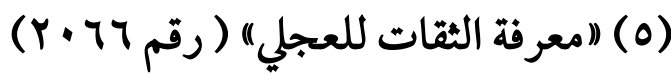
(7) (معرفة الثقات بترتيب الميثمي والسبكي - تحقيق عبد العليم البستوي")

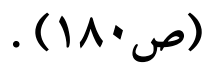


(17) جائز الحديث عند الإمام العجلي ودلالته

وأقرب الأسماء إلى الصواب : أمـا (السؤالات ) ، آو ( معرفة كنة

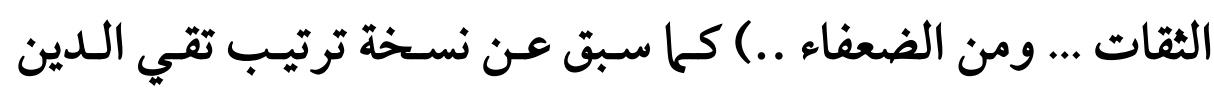
ويظهر من هذه التسمية الراجحة : آن شرط العجلي في كتابه

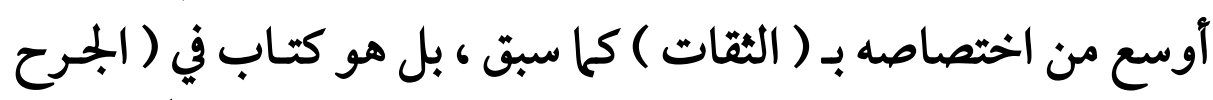

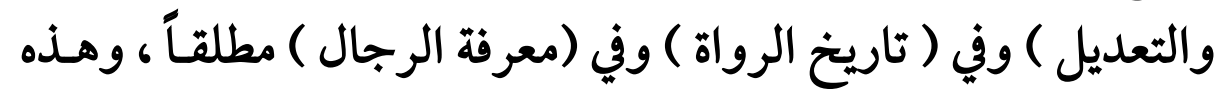

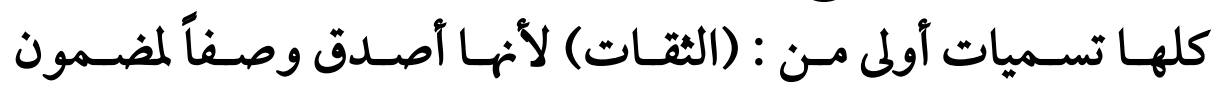

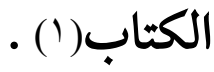

(1) (ابحث حول توثيق العجلي) للشيخ حاتم بن عارف العوني (ص ) . 
المطلب الثاني: منهج الإمام المجلي في الكتاب:

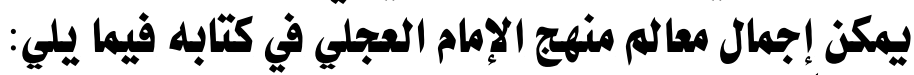

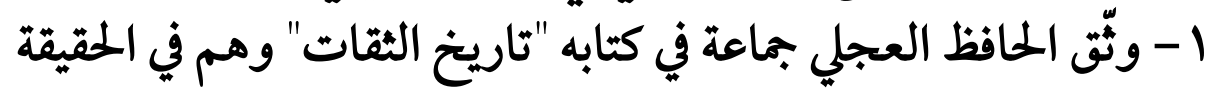

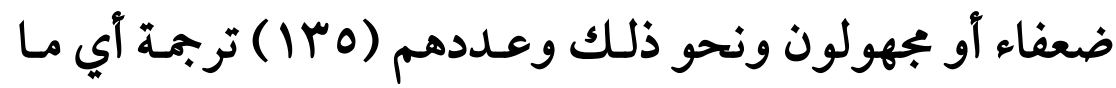
نسبته T، ب بالمائة.

r - تنـاول العجـلي في كتابـه بعـض المتروكـين والمتهمـين والكـذابين، وسكت عنهم .

rـ وصف بعض الرواة بأنه (لا بأس به) وهو في الحقيقة متروك آو متهم

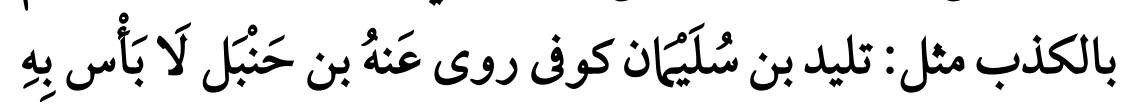

$$
\begin{aligned}
& \text { وَكَانَ يتشيع وَيُدَلس (1). }
\end{aligned}
$$

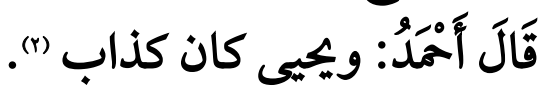

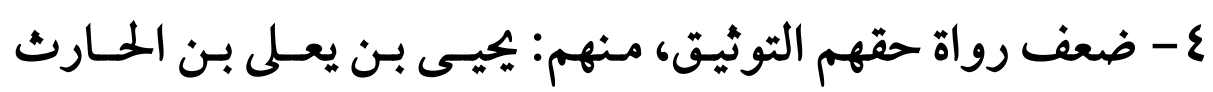
المحساربي.

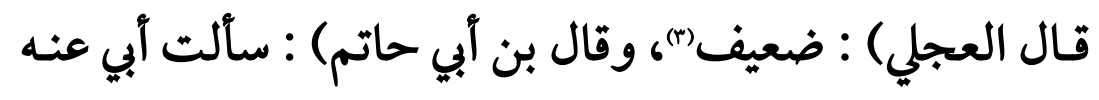
فقال: هو ثقة، وقال ابن حجر :ثقة) (8).

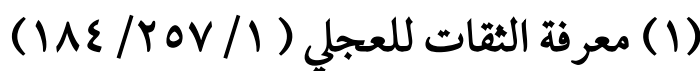

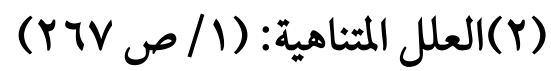

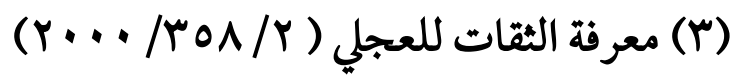

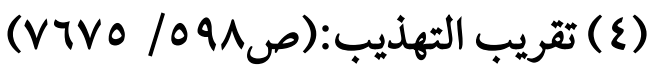


0- حرص العجلي وهو يترجم لرواة كتابه آن يذكر على نحو مختصر ما

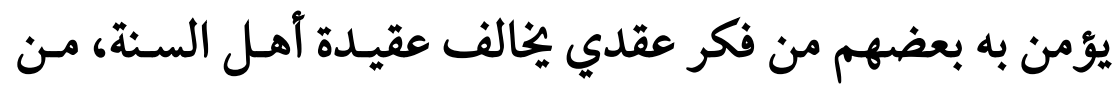

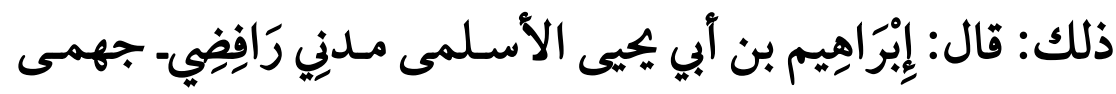

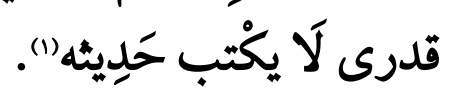

7- من الملامح البارزة في أسلوب العجلي وهو يتعامل مع الرواة جرحا

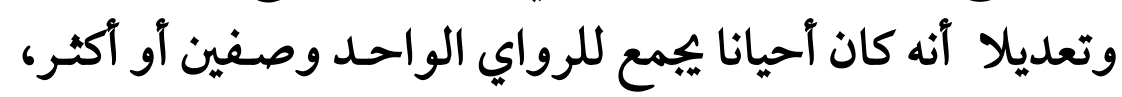

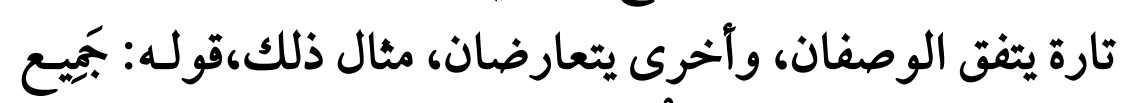

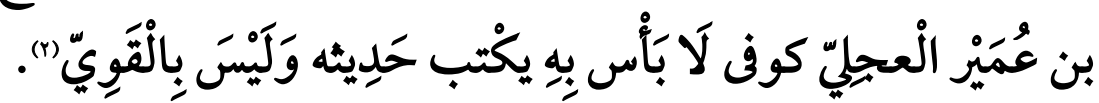

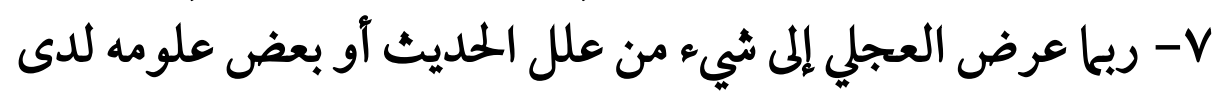

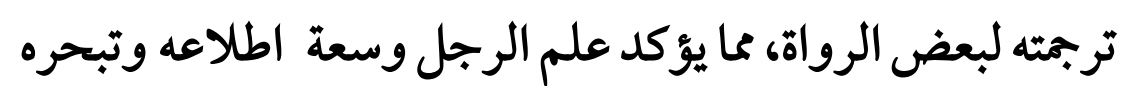

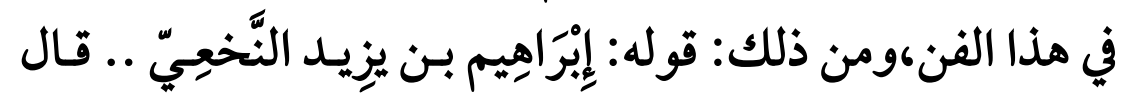

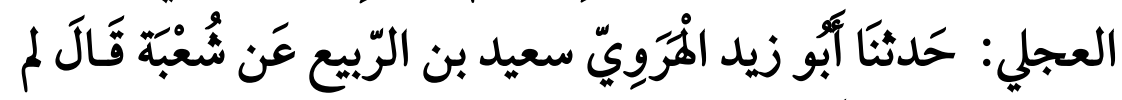

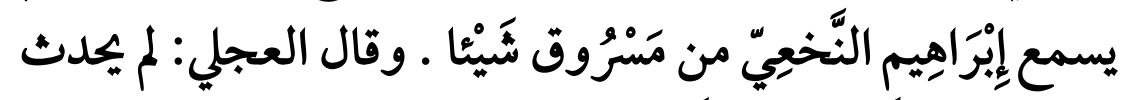

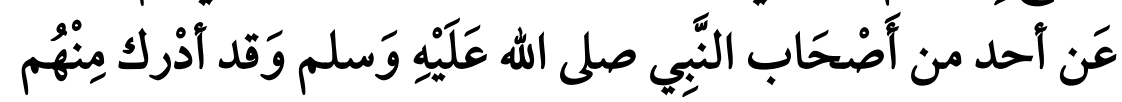

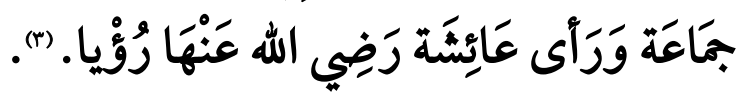

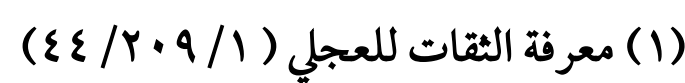

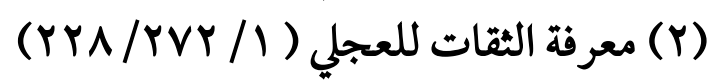

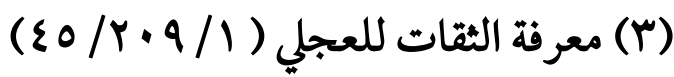




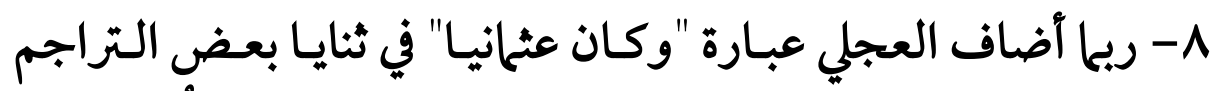

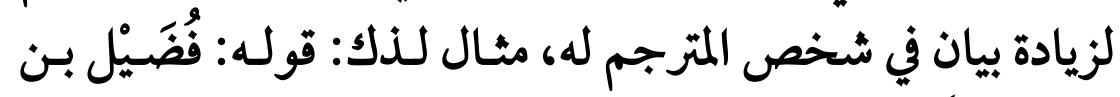

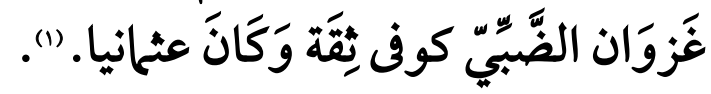

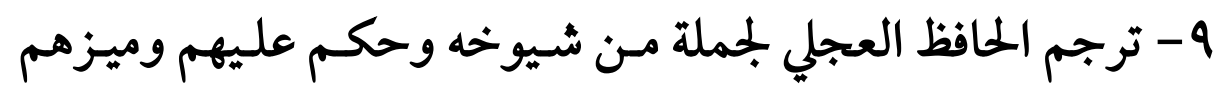

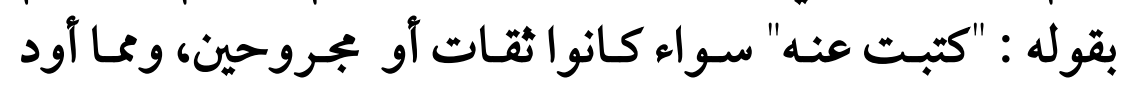

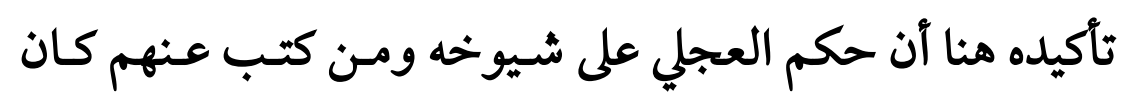

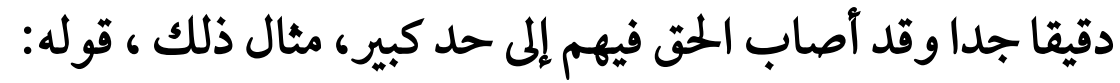

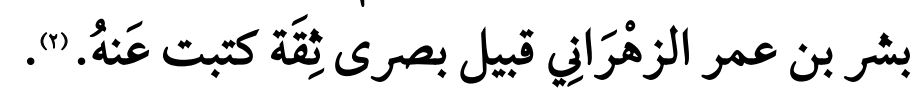

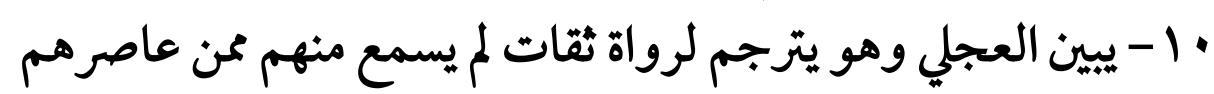

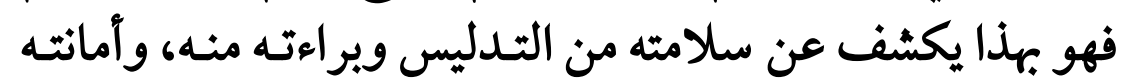

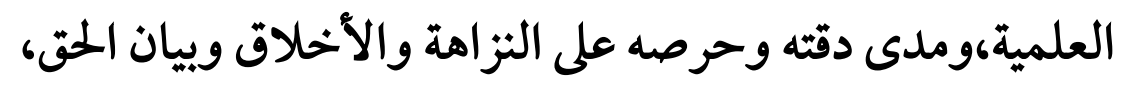

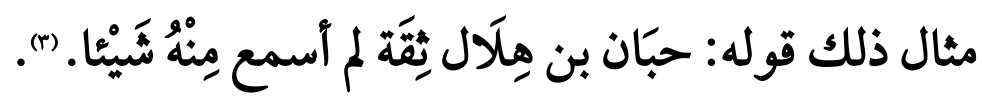

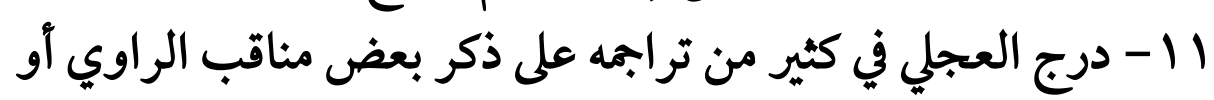

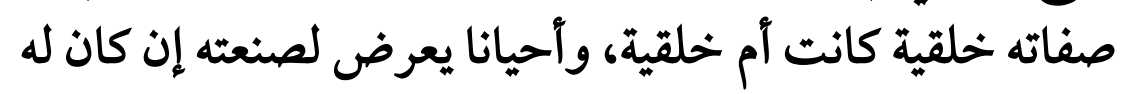

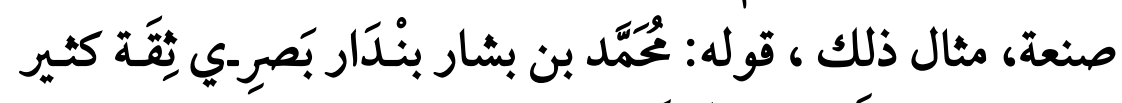
الحدِيث يكنى أَبا بكر وَكَانَ حائكا.

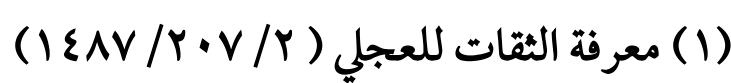

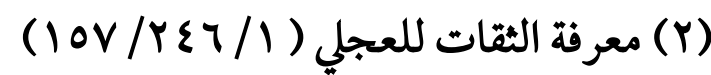

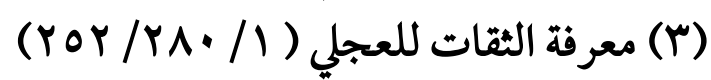

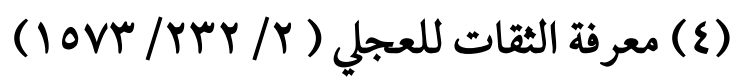


r ا - عادة العجلي أن يختصر الحكم على الراوي بكلمة أو كلمتين، لكنه

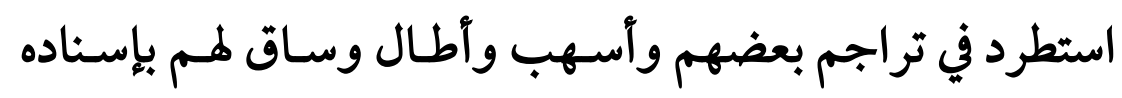

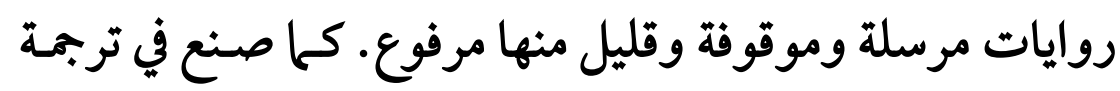
الأعمش (1) ، والربيع بن خثيم" (1) ، وجماعة.

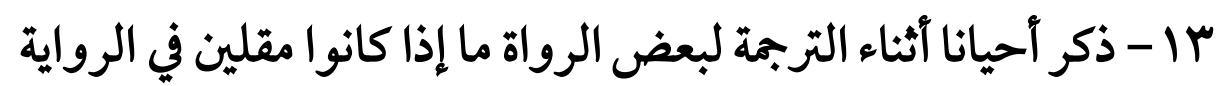

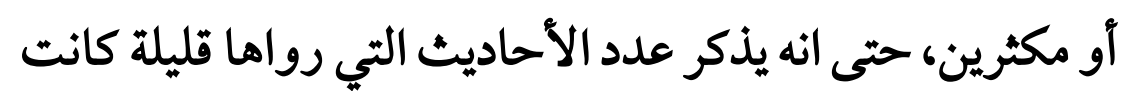

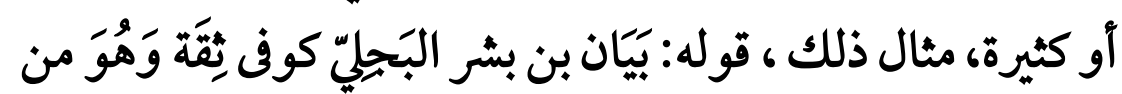

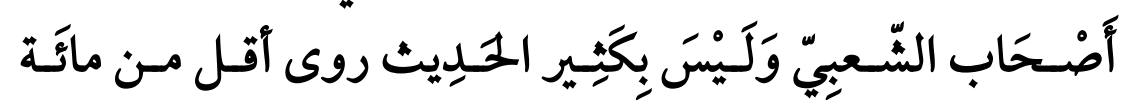
حَدِيث. (")

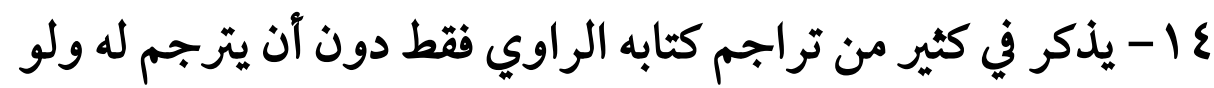

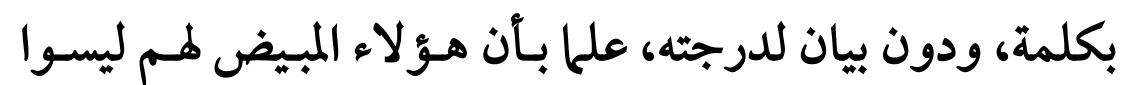

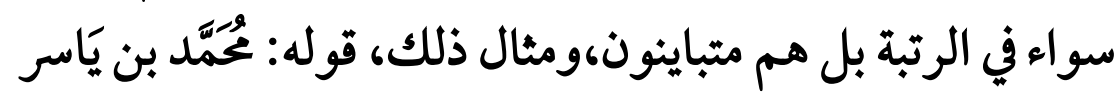
يكنى بِأبي الْيَّظَّان (8).

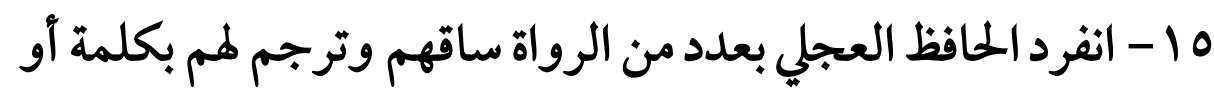

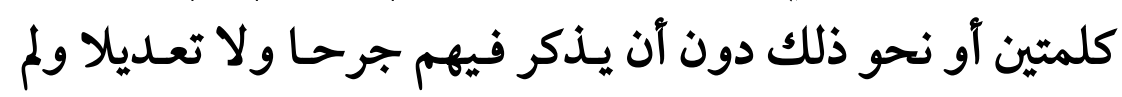

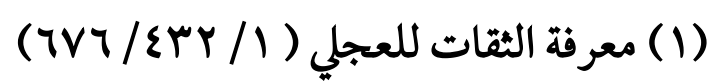

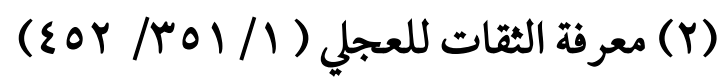

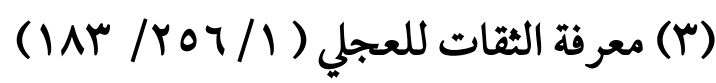

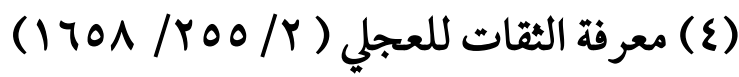


(Y)

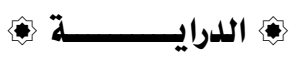

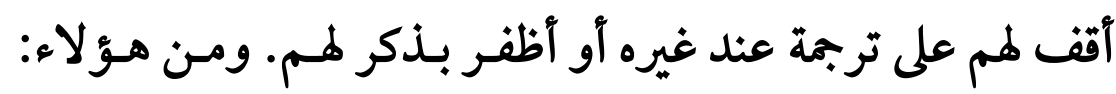

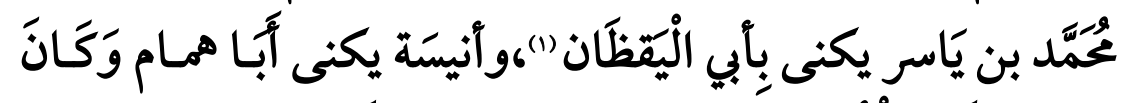

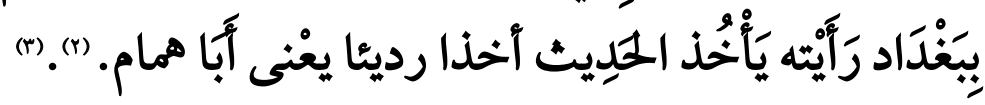

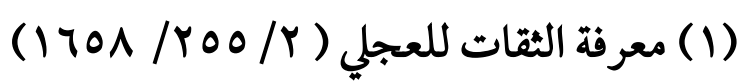

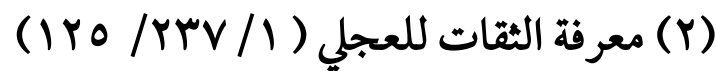

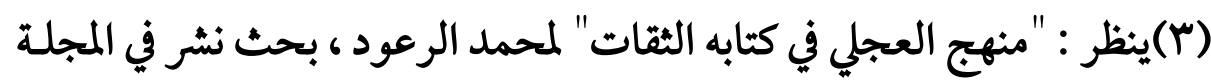

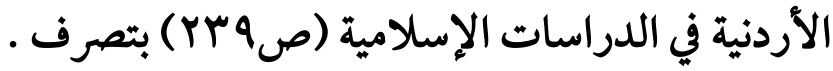


المبحث الثالث: تعريف مصطلح 》جائز)، لفة واصطاحًا، واستعمالات الإمام

ألفـاظ وعبـارات الجمـرح والتعـديل لهـا دلالـة لغويـة باعتبـار

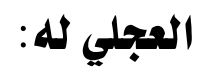

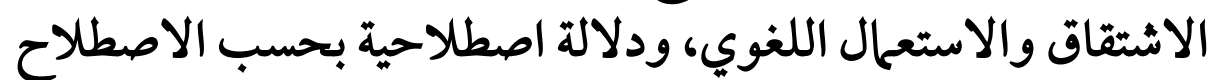

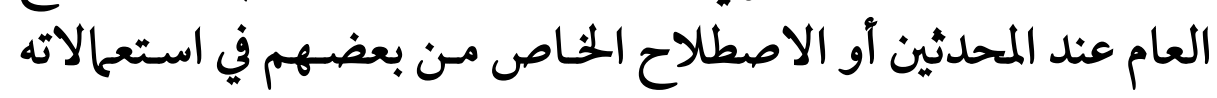
الثقدية .

وقـد يتفـق المعنى الاصطلاحي مـع معنى أو أكثر مـن المعـاني

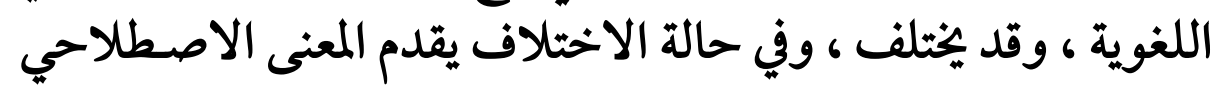
لكونه هو المقصود بالاستعال.

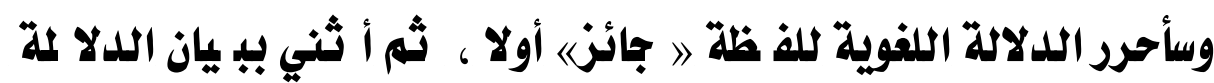

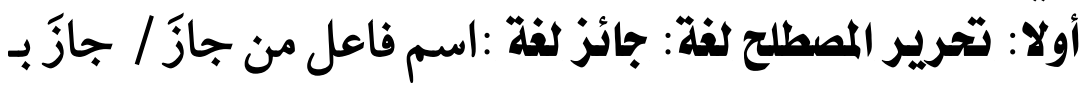

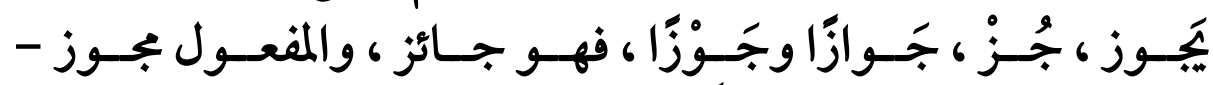

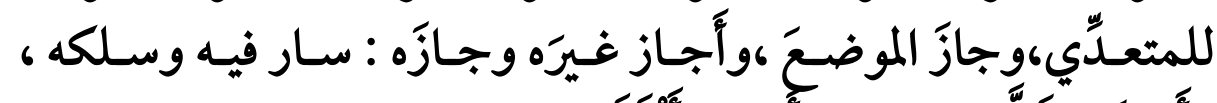

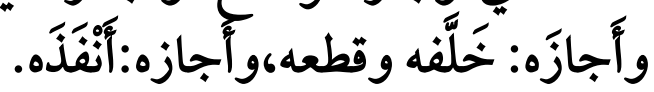

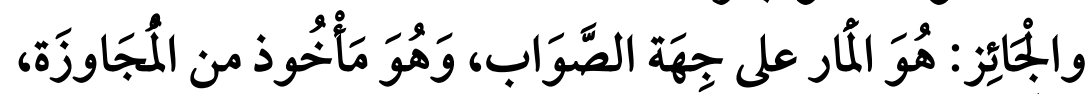

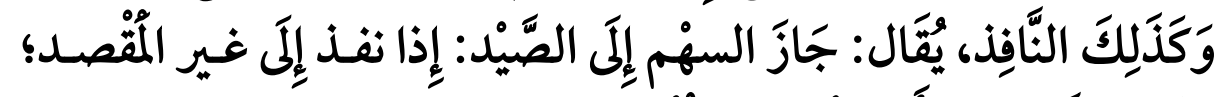

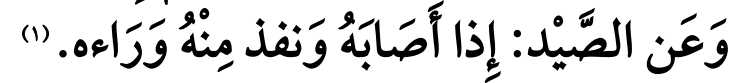

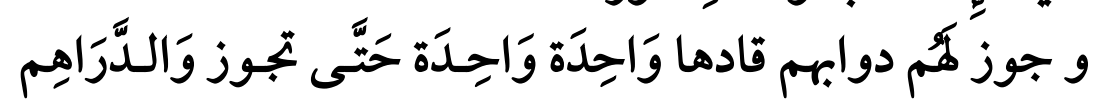

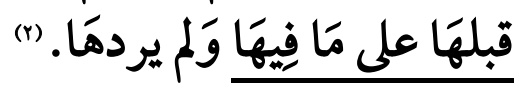

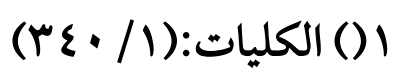

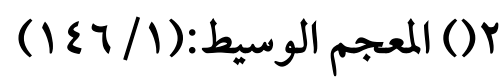




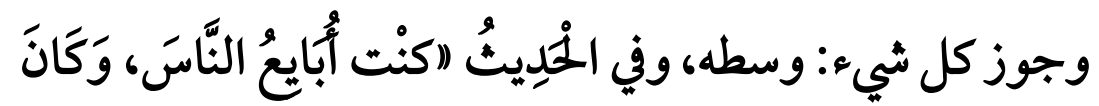

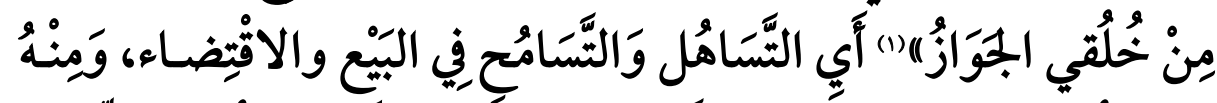

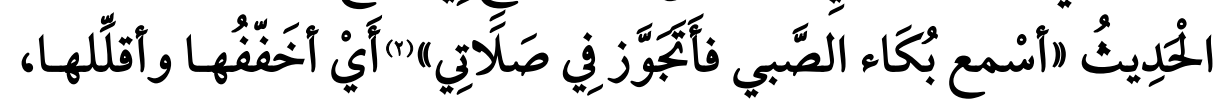

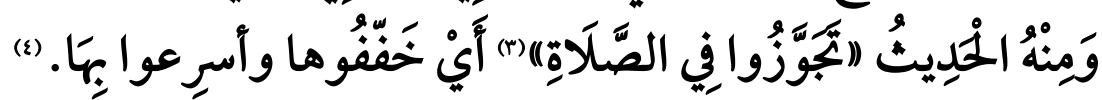

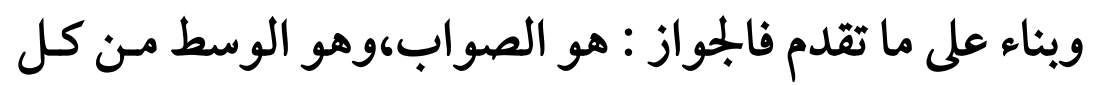
شيء، أو المقبول منه على ما فيه من قصور.

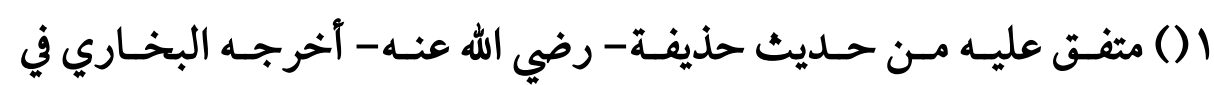

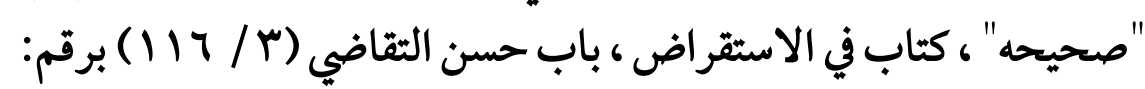

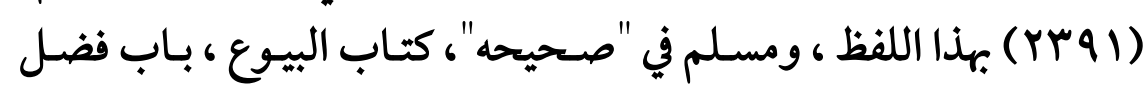

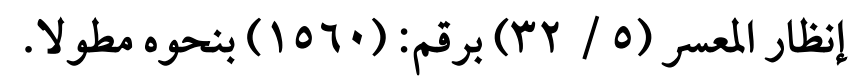

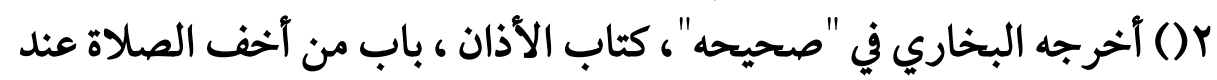

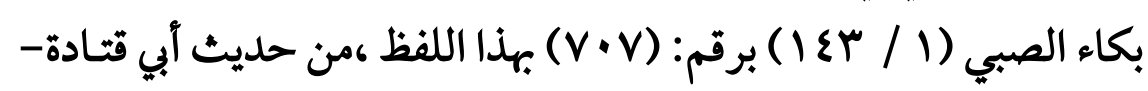
رضي الله عنه- بكاء الهي

r() أخرجه البخاري في "صحيحه" ،كتاب الأذان ، باب إذا صلى لنفسه فليطول

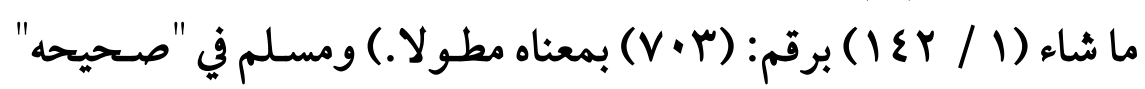

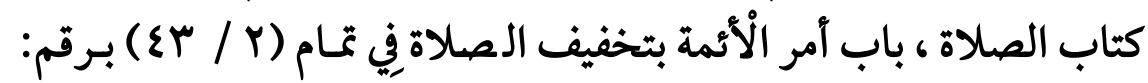

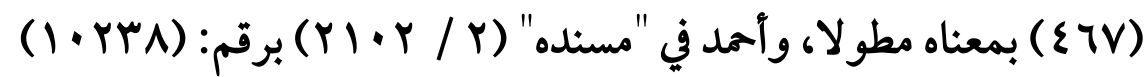
بذا اللفظ.

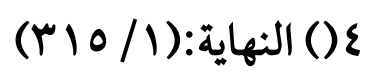


ثانيا: ملدول مصطلح 》جائزن عند أئمة الجرح والتعديل:

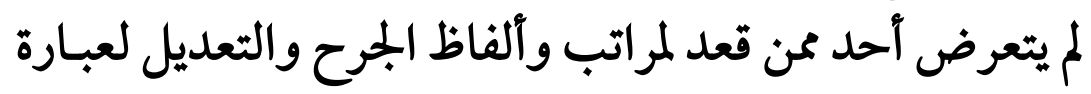

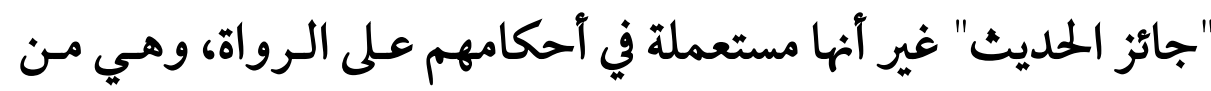

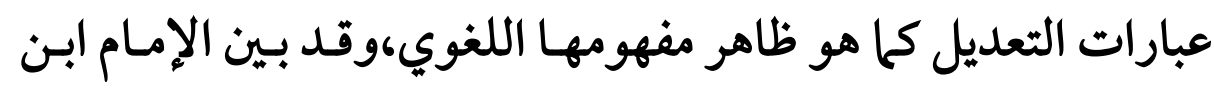

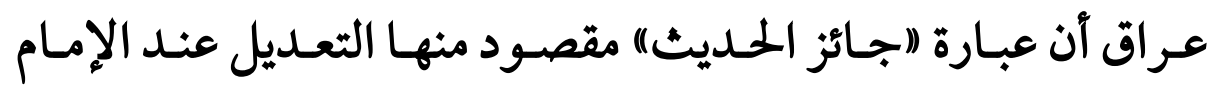
العجلي، فقال: بعد نقل كلام العجلي في مندل بن علي "ا"جَائز الحَدِيث

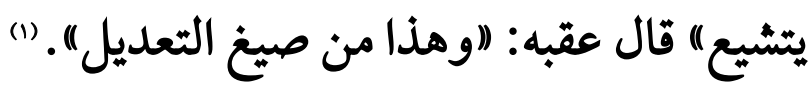

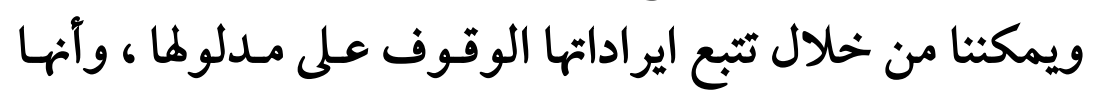

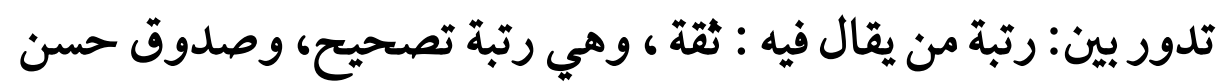

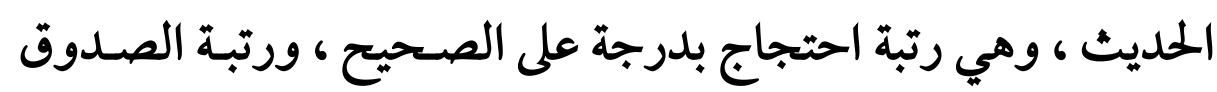
الذي له أوهام معدودة، ورتبة المعتبر به. وقد إستعملها الإمـام العجلي في تلك المراتب لكن لكن في سـياق التركيب و الإفراد فمن ذلك استعحال هذه اللفظه مع قرنها بكلمة (اثقة)"

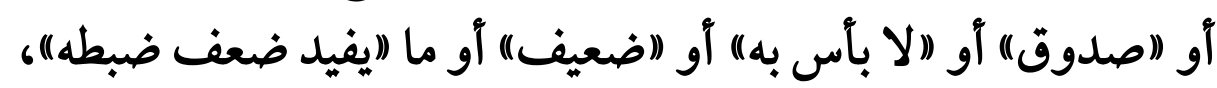

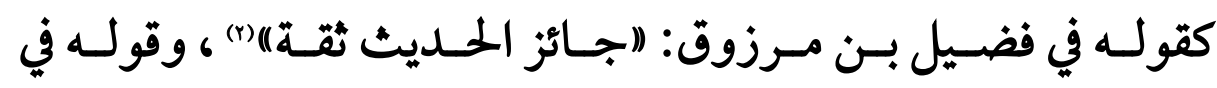
عبدالرحمن بن إسحاق بن سعد الواسطي قال: (اضعيف جائز الحديث

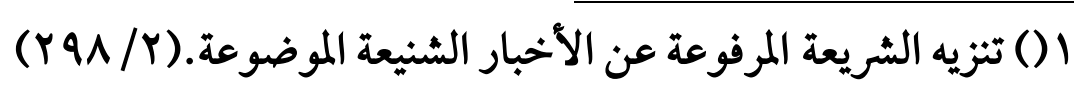

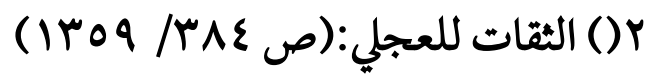


يكتب حديثه)|(1)،وقال في صالح بن حبان: ((جائز الحديث يكتب حديثه

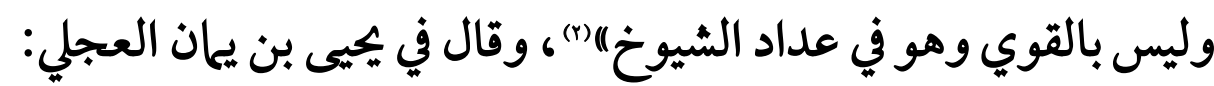

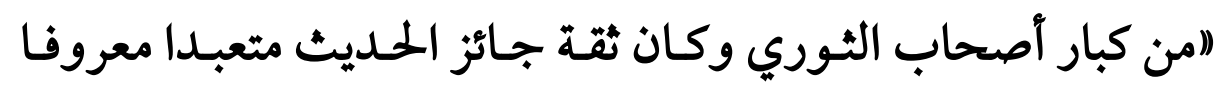
بالحديث صدوقا إلا أنه فلج بآخره فتغير حفظه وكان فقيرا صبور ا(ا)(r). وكذا قال ابن معين في قابوس بن أبي ظبيان الجنبي: (اثقـة جـائز

() (الحديث)

فمن إستع|لما في مرتبة الصدوق حال الإفراد:

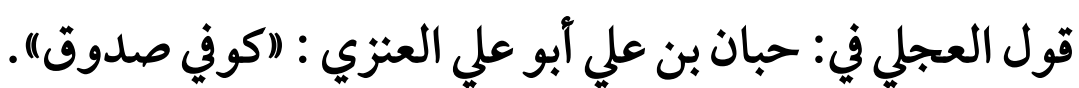

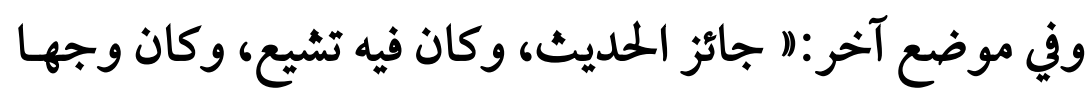

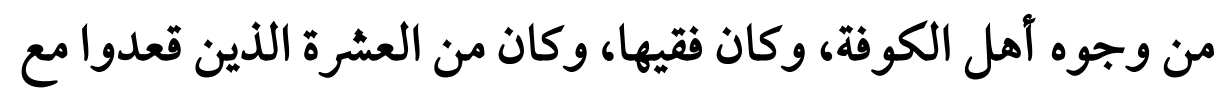
أبي حنيفة ثم عاداه وتركها. هكذا نقله مغلطاي مفرقا وليس مركبا كا وقع في إكحال تهذيب

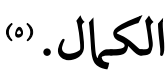

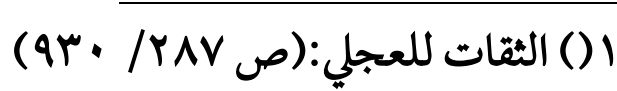

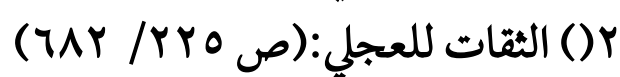

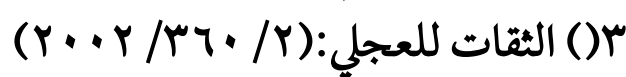

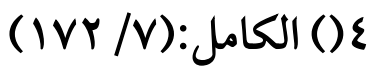

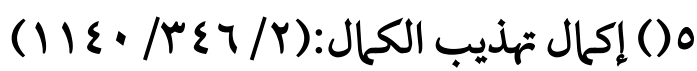


وقد وقع في مطبوع العجلي (1) الجمـع بـين اللفظتين في عبارة

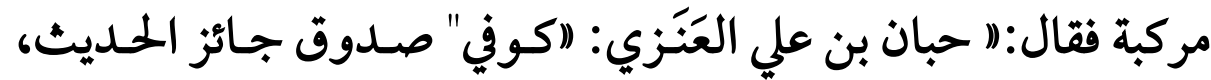

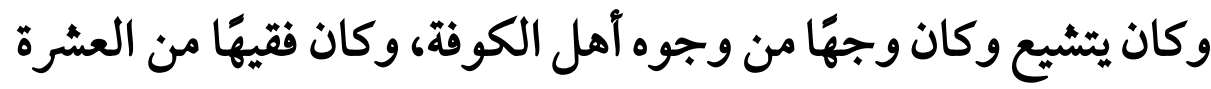

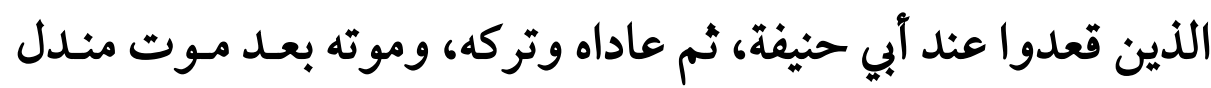

$$
\text { آخيه. " آنين قعد }
$$

وهذه قرينة على تسـاوي اللفظتين في هـذا الراوي عند الإمـام

العجلي ،وليس تغير لاجتهاد العجلي فيه.

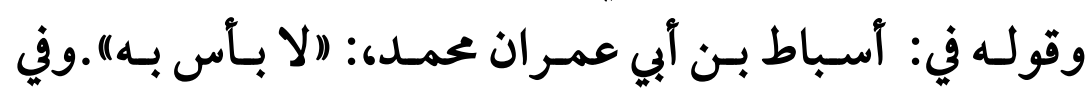

$$
\text { موضع آخر: (اجائز الحديث)) (r)(r). }
$$

وقوله في:عباد بن منصور الناجي: (لا بأس به يكتب حديثه)"،

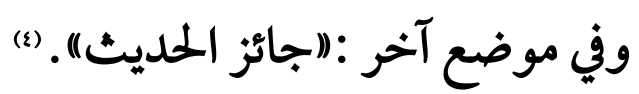

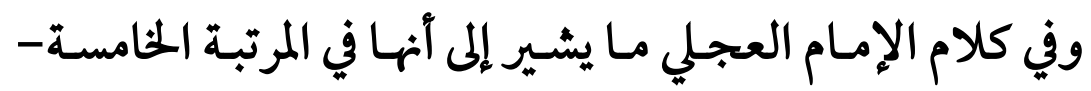

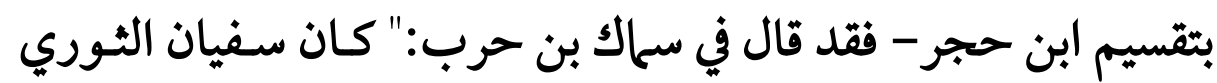

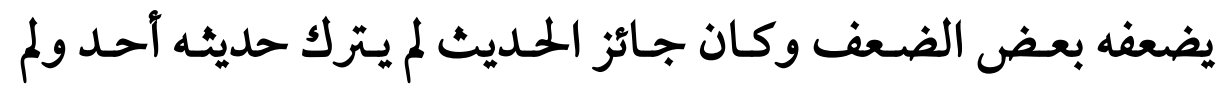
يرغب عنه أحد" ومثل هذا ينطبق على من كان صدوقاً فيه ضعف.

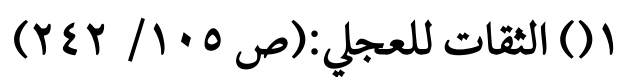

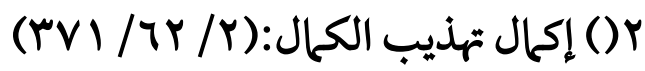

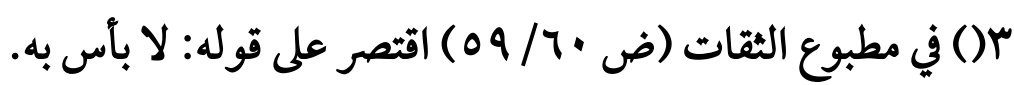

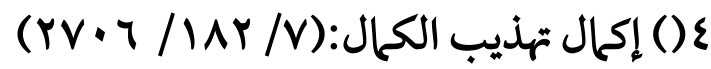


كما قال ابن التركماني في الليث بن أبي سليم: قال العجلى: "جائز

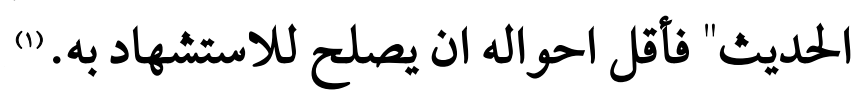

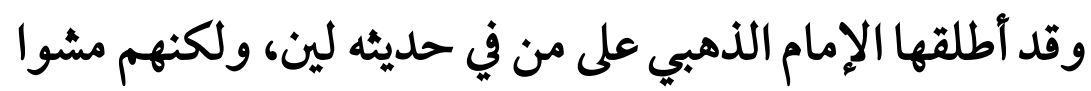

حديثه، ولم يتركوه و جاز على ما فيه من الضعف:

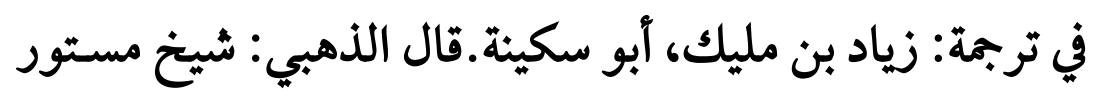

$$
\text { ما وثق ولا ضعف فهو جائز الحديث. (") }
$$

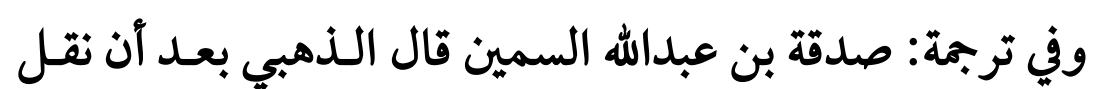

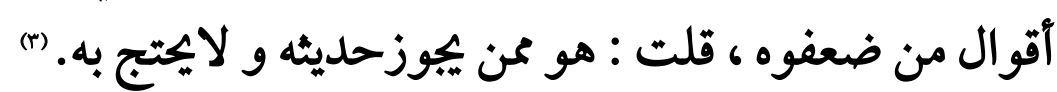

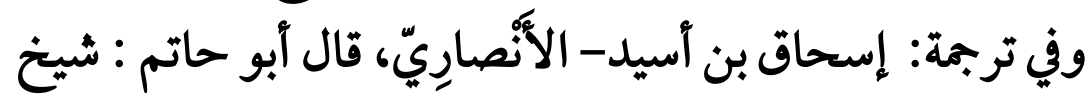

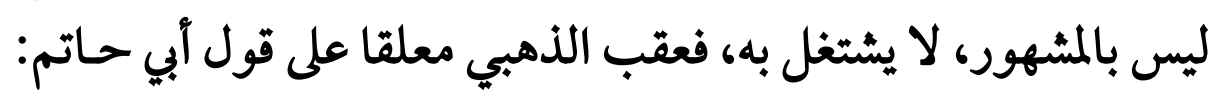

حدث عنه يميى بن أيوب والليث، وهو جائز الحديث.

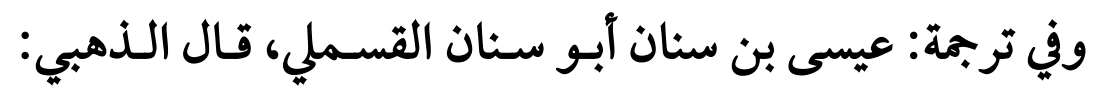

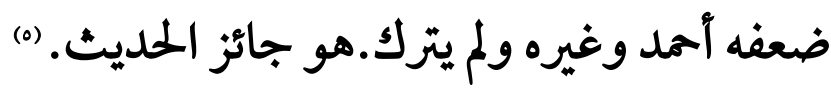

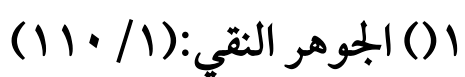

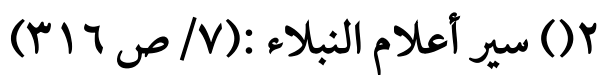

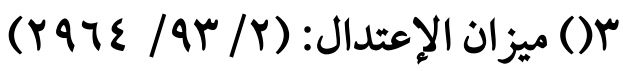

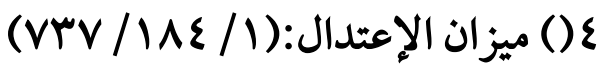

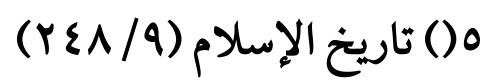


وفي ترجمة:منصور بن سعد البصري اللؤلؤي، قال الذهبي:

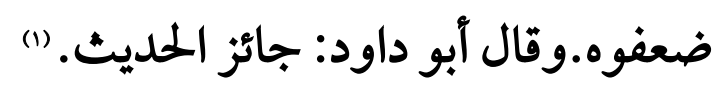

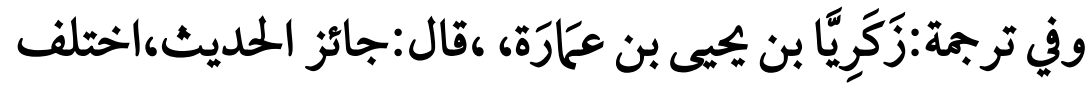

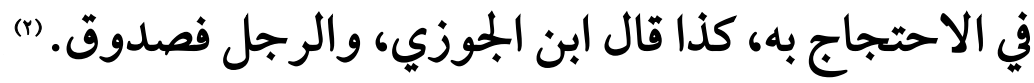

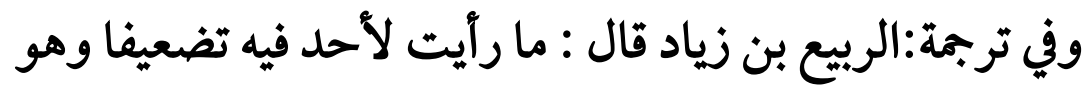

جائز الحديث . (r)

وفي ترجمة:ســعيد بــن عمارة،قــال الــذهبي: قــال الأزدي:

متروك.قلت: روى عنه بقية، وعلي بن عباس، وجماعة.جائز الحلديث.

وفي ترجمة:محمد بن عبد الله بن ميمون،قال الذهبي: له حـديث

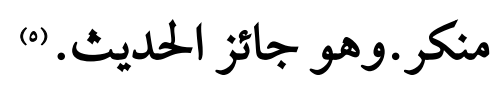

فيستفاد من ذلك أن جائز الحديث عند الإمام الذهبي يطلق على فلى

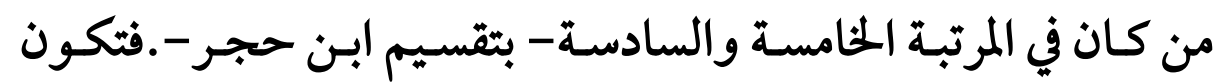

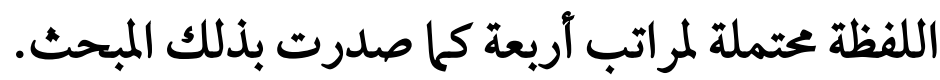

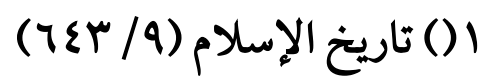

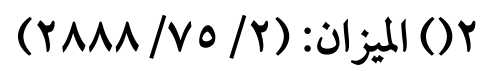

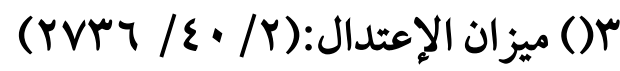

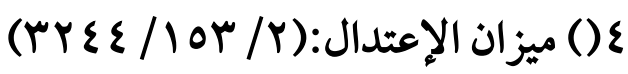

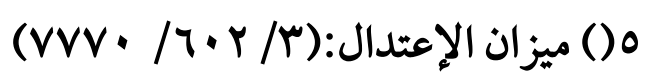


ولمعرفة أي المراتب أقـرب إلى مقصـود الإمـام العجـلي في كل

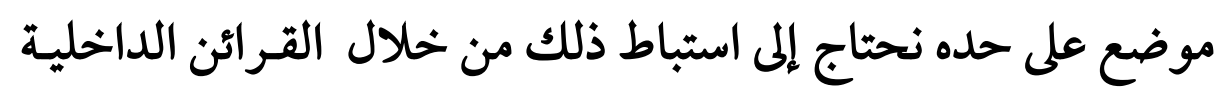
والخارجية.

والمقصود بالقرائن ما يدل على المراد دون تصريح به ، وذلك مما

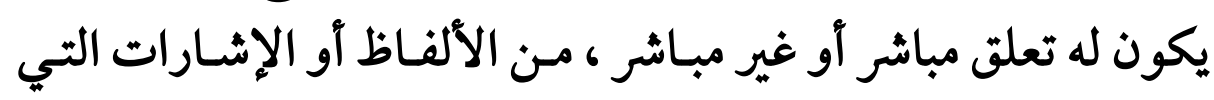

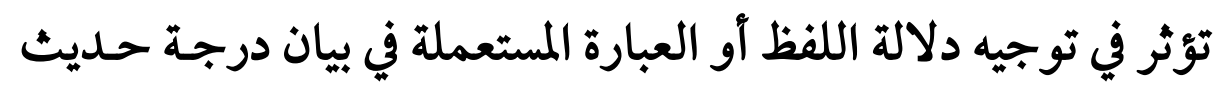
الراوي ، أو بيان حاله جرحا أو تعديلا.

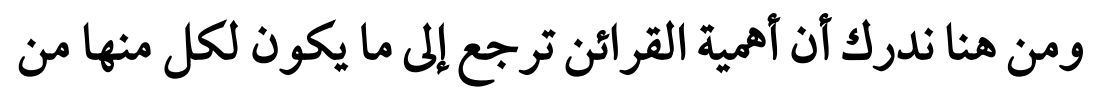

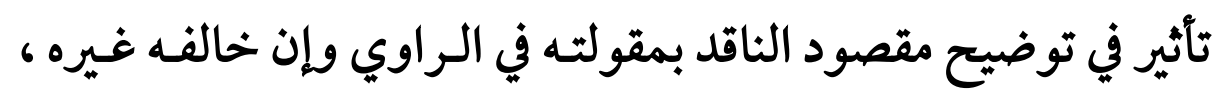

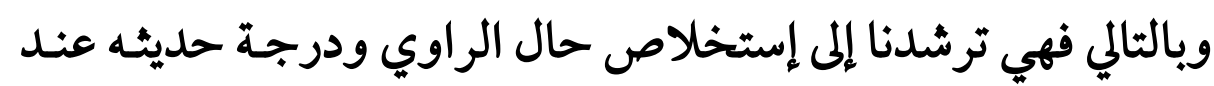

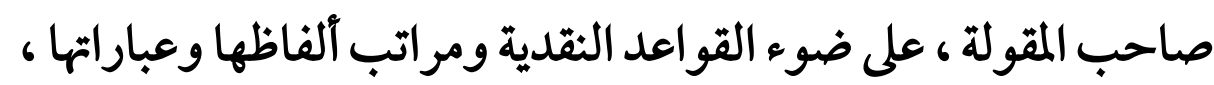

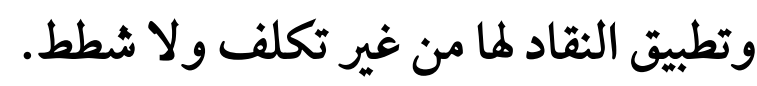
ويمكن تقسيم القرائن إلى قسمين:

القسم الأول:القرائن الداخلية أو المباشرة ، وهي: ولقئ ما يستفاد من

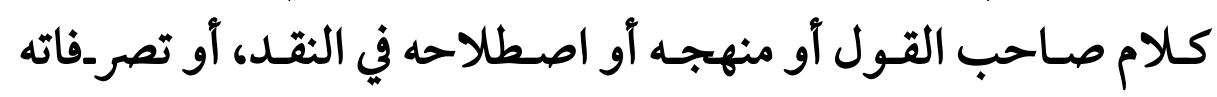

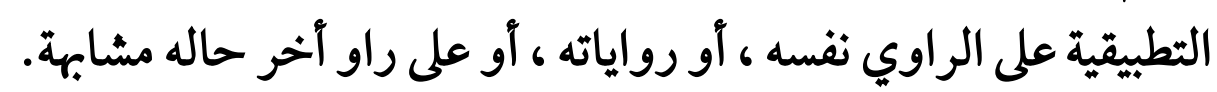

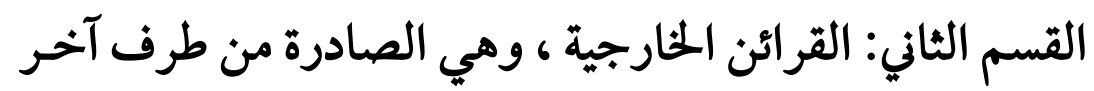

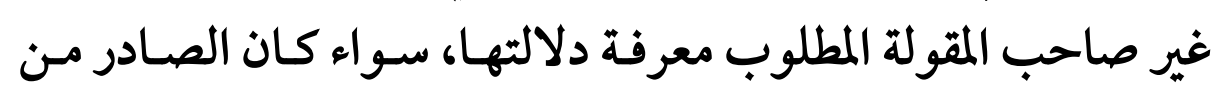
الطرف الآخر متعلقا بذات الراوي المتكلم فيه آو بمروياته. 
$(r \cdot)$

وهذا القسم آقل تأثيرا من الأول لكن عند إفتقاد قرينة داخلية

فإنه يمكن الاستئناس بلا تفيده القرينة الخارجية (1).

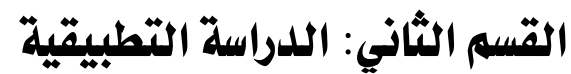

ملدول مصطلح 》جائز الحديث/ عند الإمام العجلي في كتابه 》معرفة الثقاته

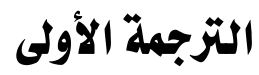

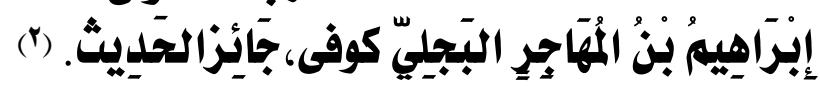

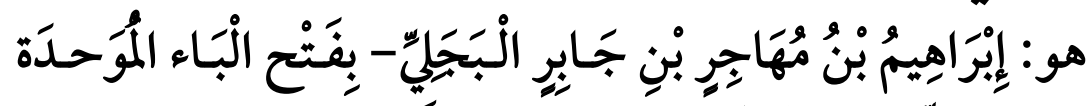

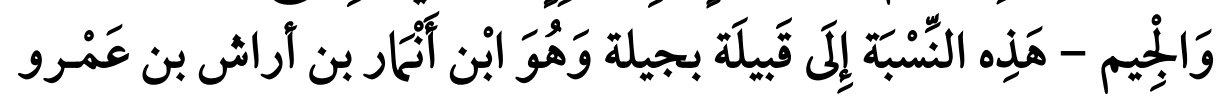

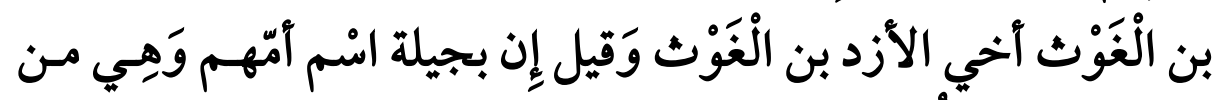

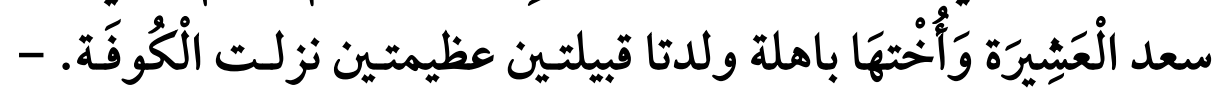

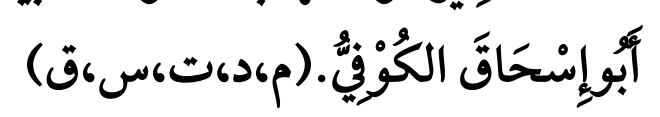

روى عـن :الشعبي، وإبـراهيم النخعي ، وزيـاد بـن حسدير،

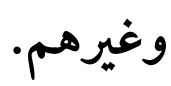

روى عنه :شعبة، وسفيان الثوري ، وشريك ، وغيرهم .

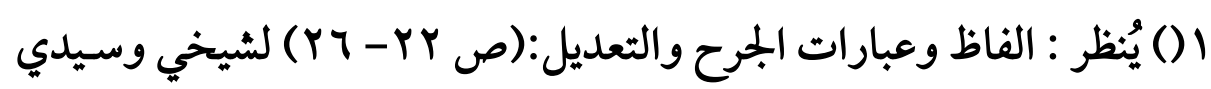
فضيلة الأستاذ الدكتور أمحد معبد.

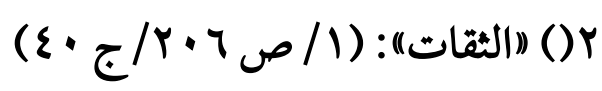


قال ابن سعد : ثقة،وقال الذهبي مـرة : صدوق، وقال: ثقة،

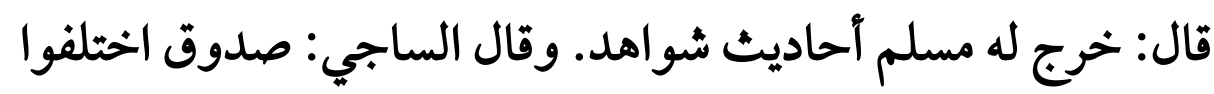

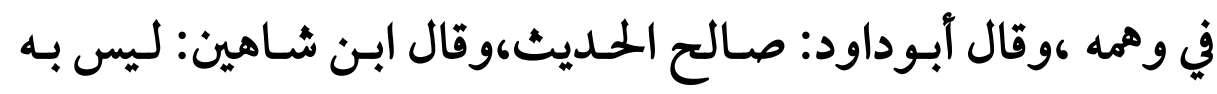

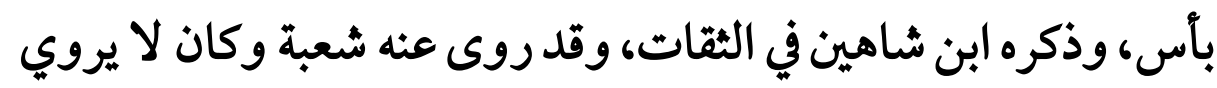

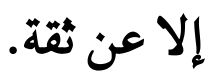

وقال الثوري ،وأحمد بن حنبل: لابأس به ،وقال المروذي: سألثه

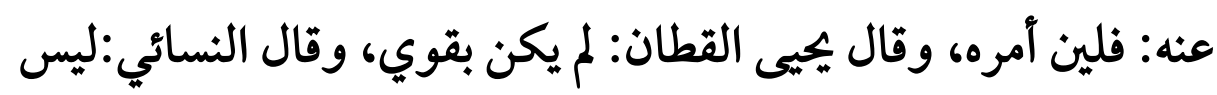

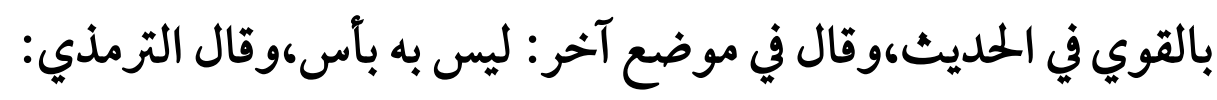
لم يكن بالقوي.وقال البيهقي: غير قوي.

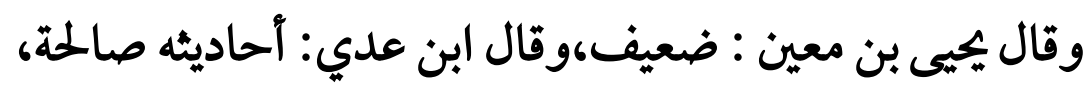

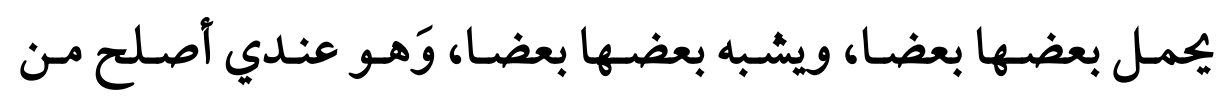

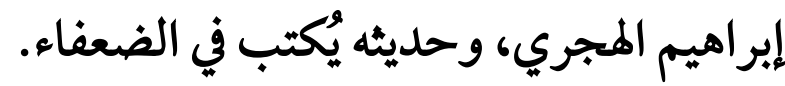

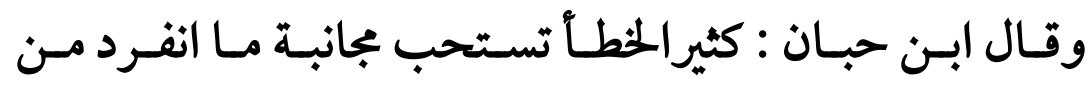

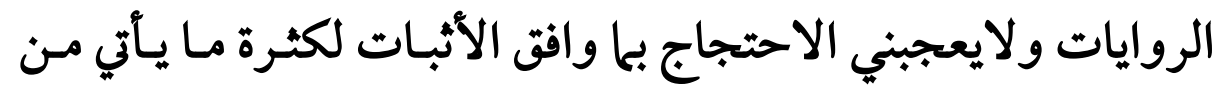

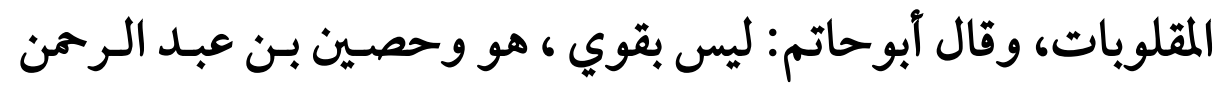

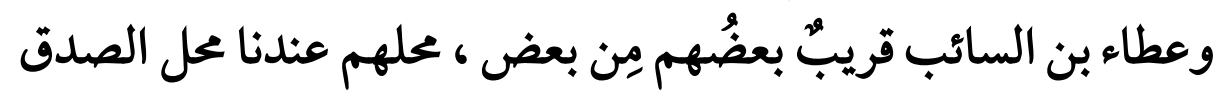

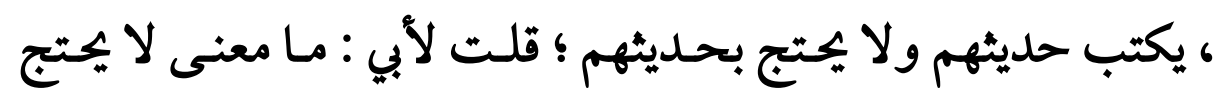

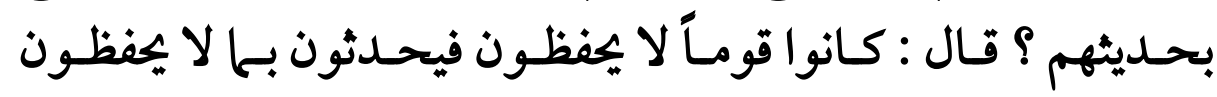
فيغلطون ترى في أحاديثهم اضطراباً ما شئت. 
وقـال الحاكم:قلـت للـدارقطني فـإبراهيم بـن مهـاجر؟ قـال:

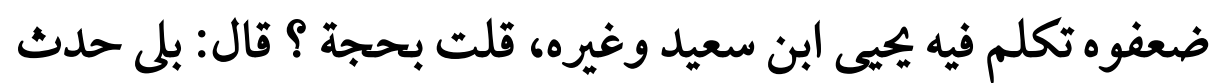

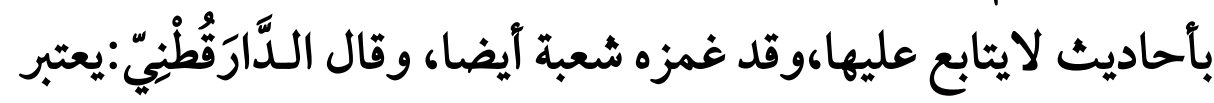
به. وقال ابن حجر : صدوق لين الحفظ ، من صغار التابعين. (1)

\section{المناقشة والتزجيح}

من خلال مراجعة أقوال النقـاد في إبـراهيم بـن مهاجر، يظهر إختلاف الأئمة في بيان حالة والرتبة التي يندرج فيها تعديلا أو تجريها،

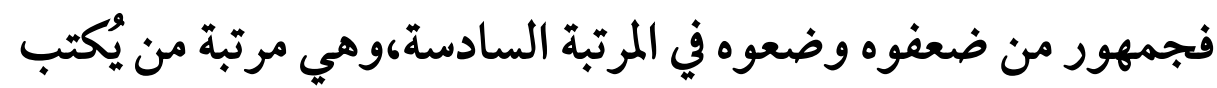

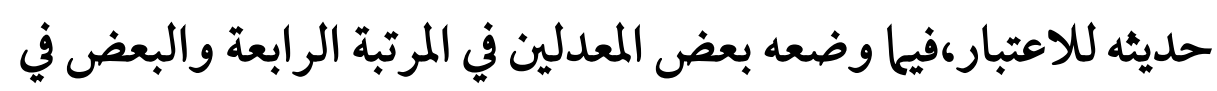

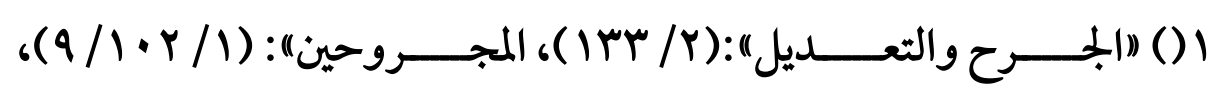

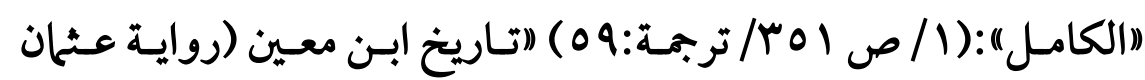

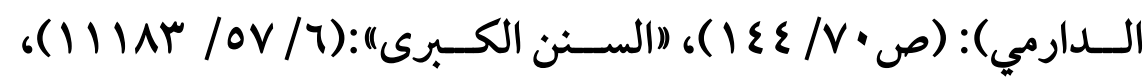

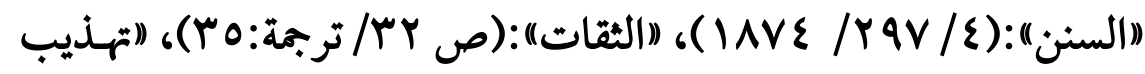

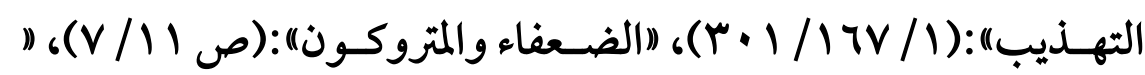

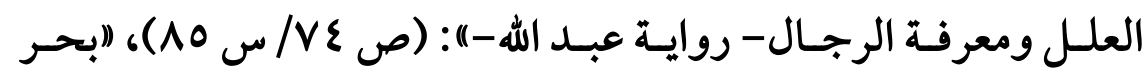

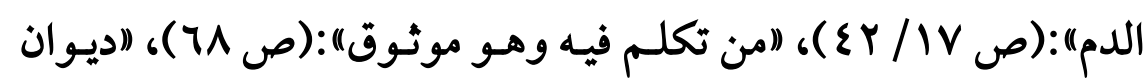

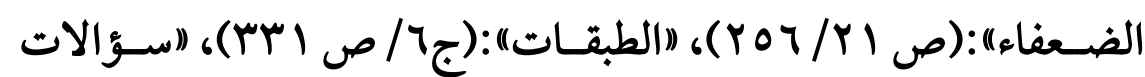

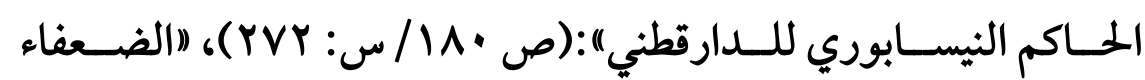

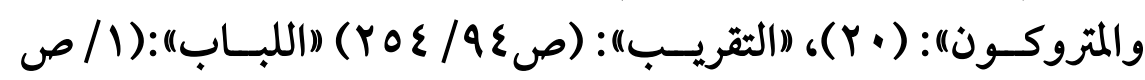


المرتبة الخامسة،وأطلق البعض القول بتوثيقة وهو متعقب بـا لإبراهيم

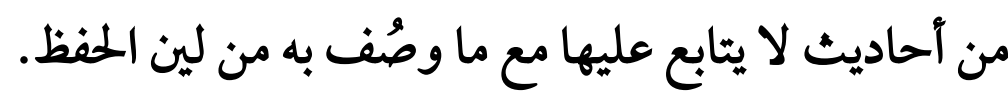
ولعل الأقرب في حال إبراهيم عده في أدنى مراتب التعديل فهو ماته صدوق يهم، إن وافق الثقات فحديثه حسن وإن خالفهم فضعيف.

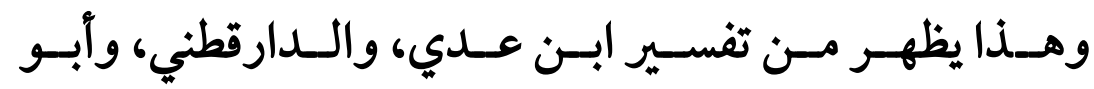

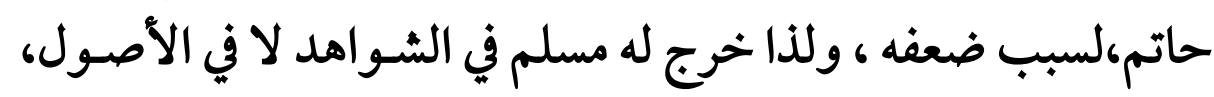

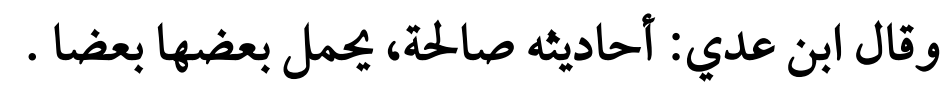

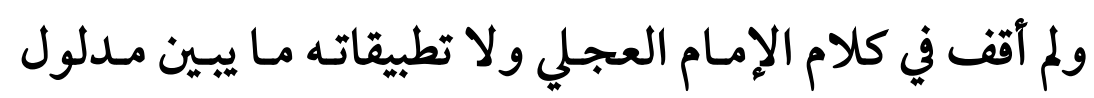

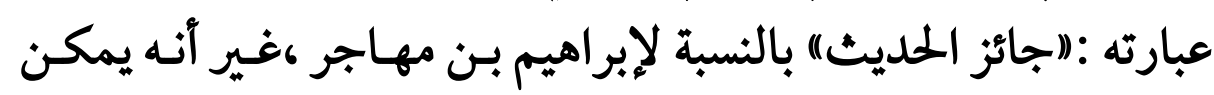

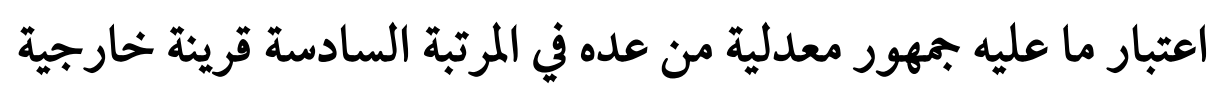

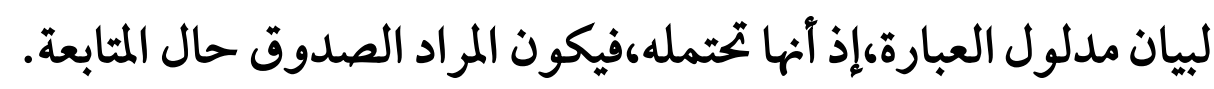

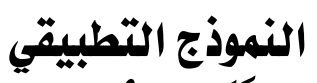

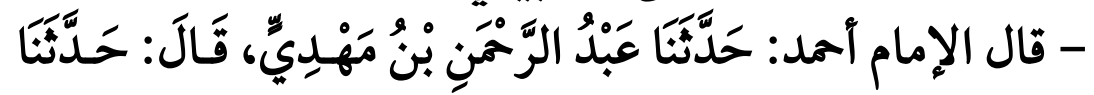

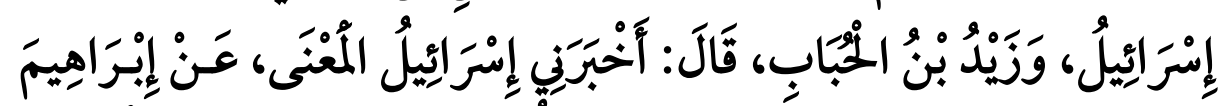

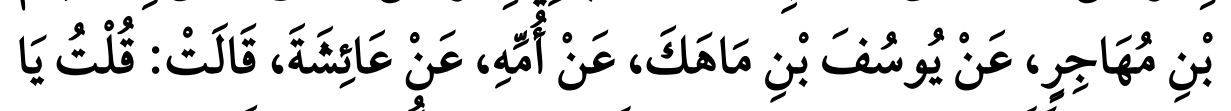

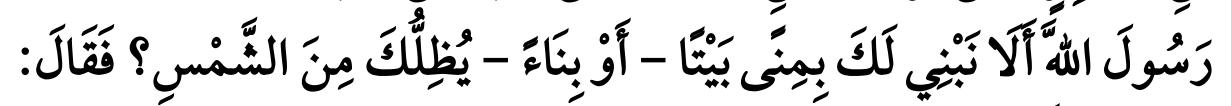

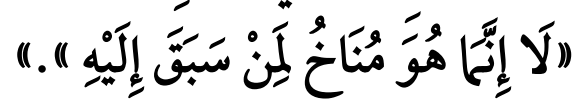

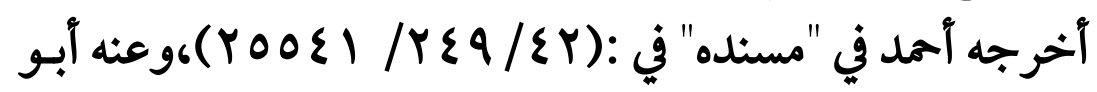

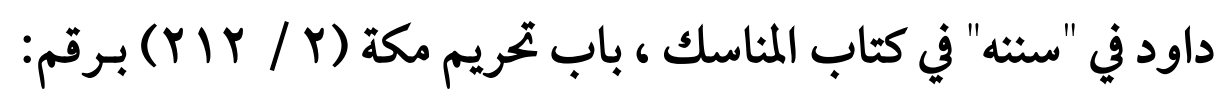
(19 ( 19 ) عن عبد الرحمن بن مهدي، عن إسرائيل، به. 


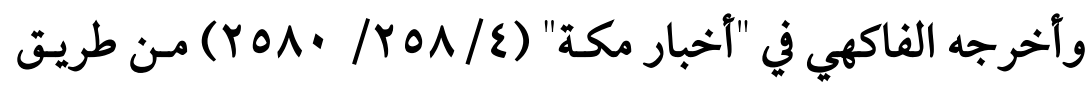

عبد الرحمن بن مهدي، به.

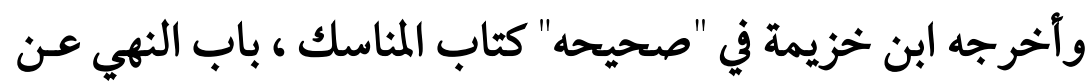

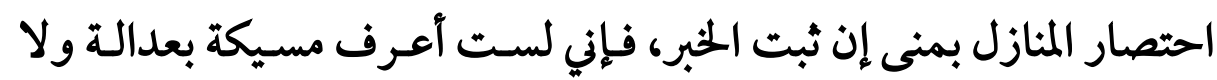

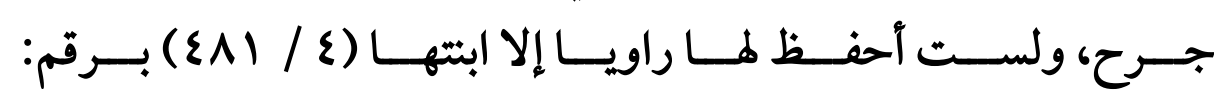

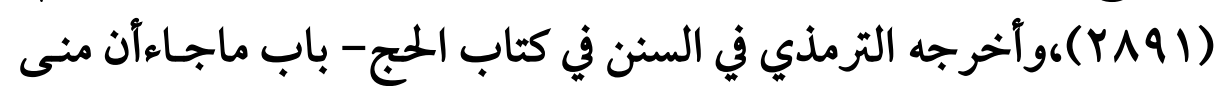

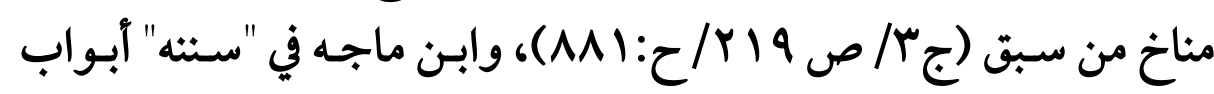

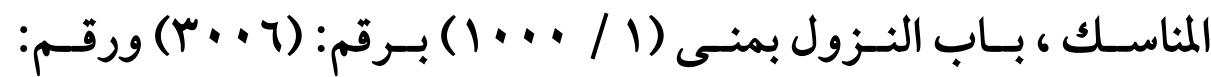

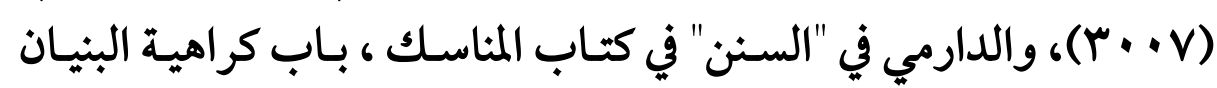

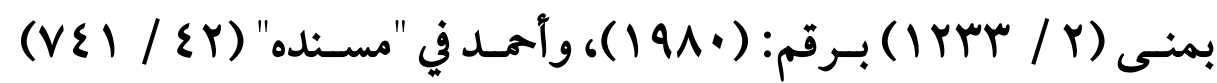

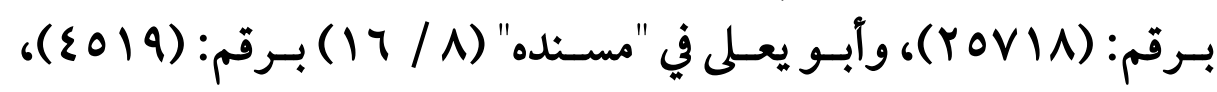
جميعهم من طرق عن وكيع، عن إسرائيل ، بـه. وقال الترمـذي عقبه: ("هَذَّا

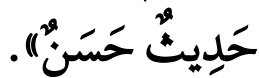
وآخرجه الحاكم في "مستدركه" كتاب المناسك ، منى مناخ من سبق

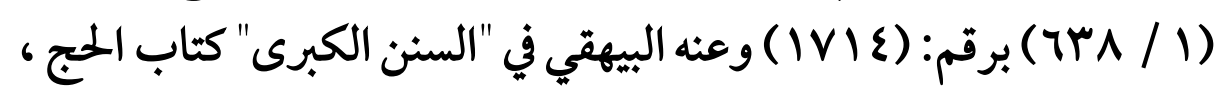

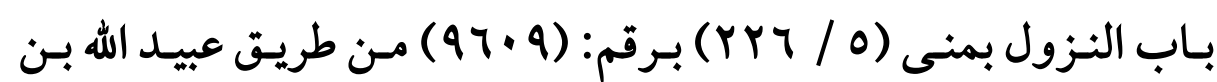

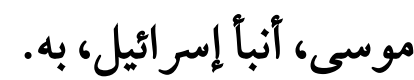
وقال الحاكم: هذا حديث صحيح على شرط مسلم، ولم يخرجاه " 


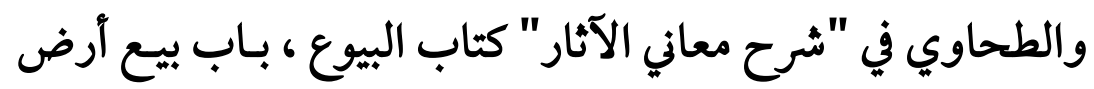

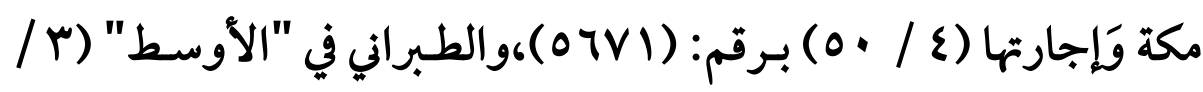

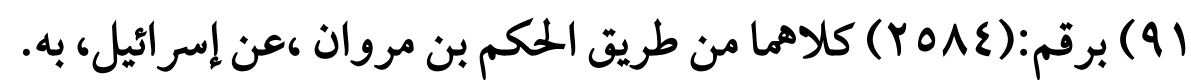

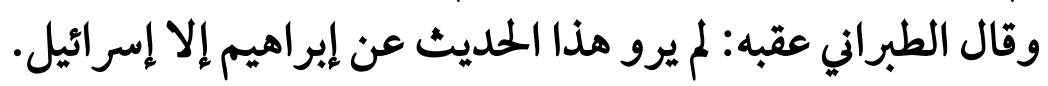

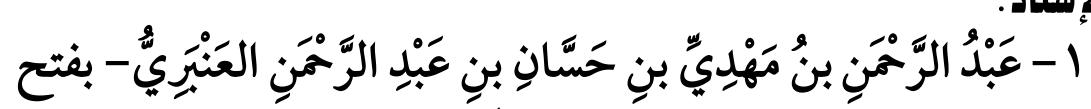
دراسة الإسناد:

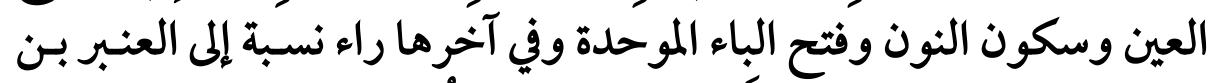

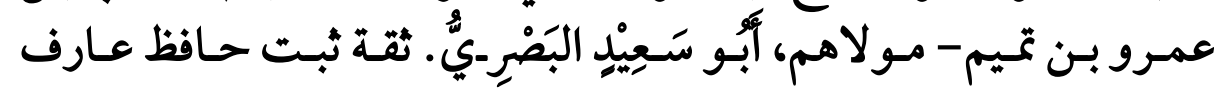

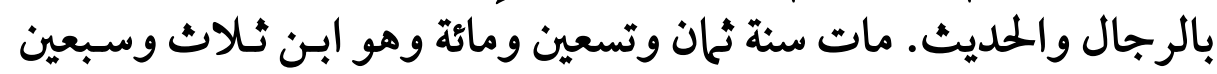

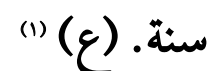

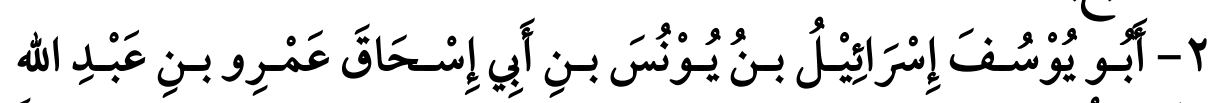

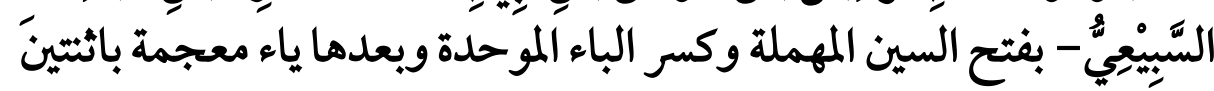

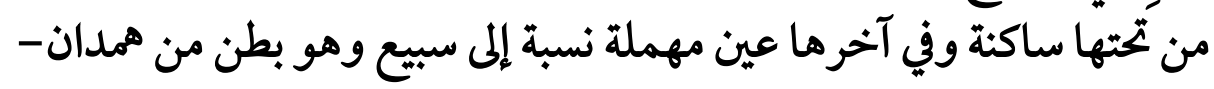

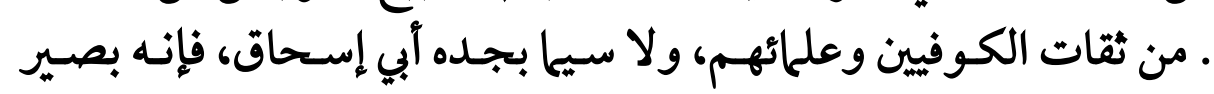

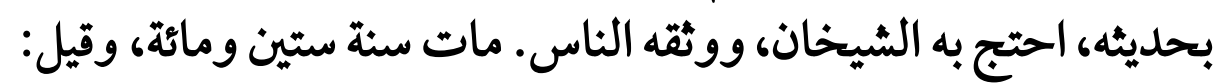

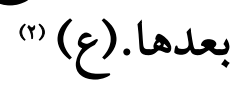

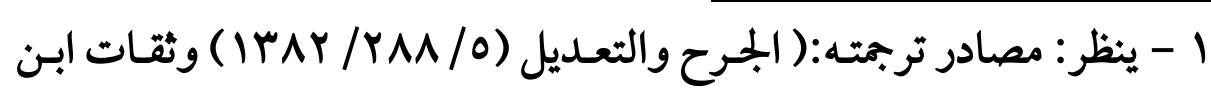

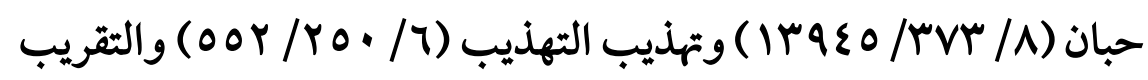

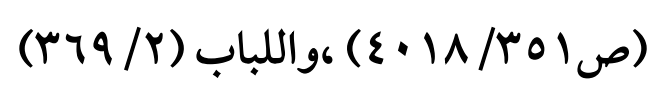

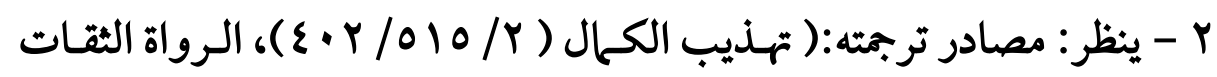

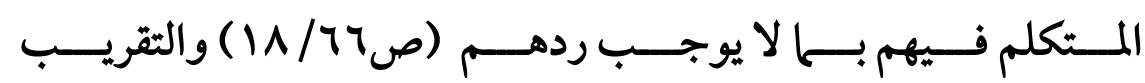

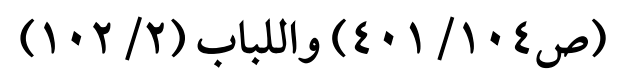




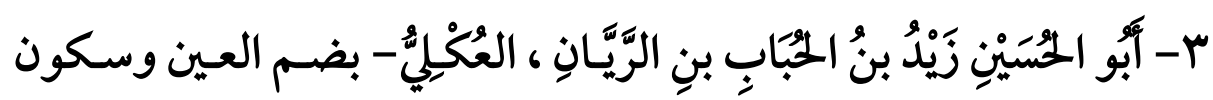

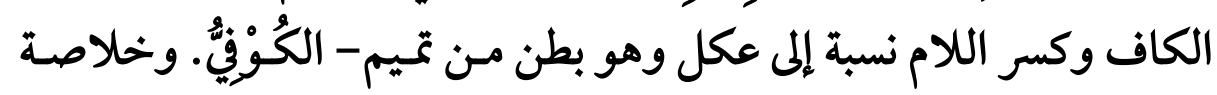

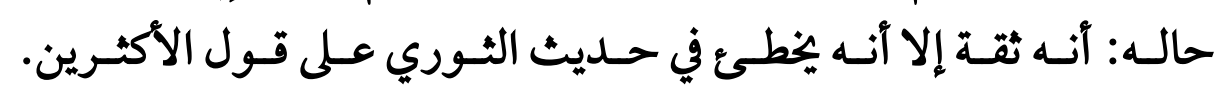

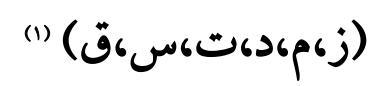

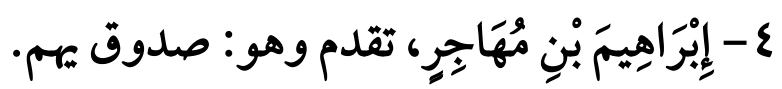

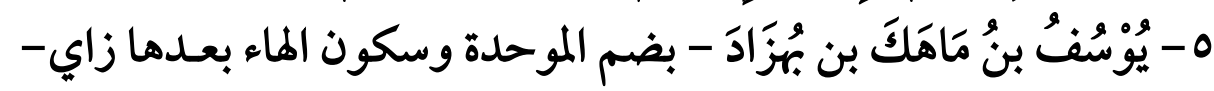

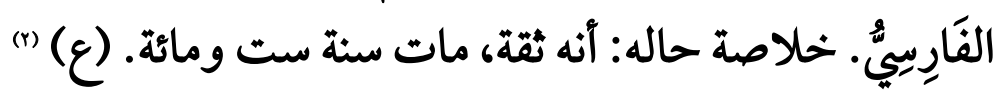

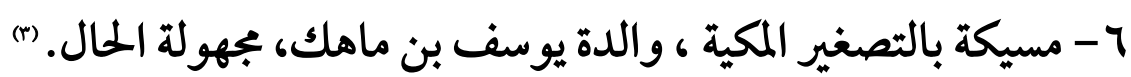

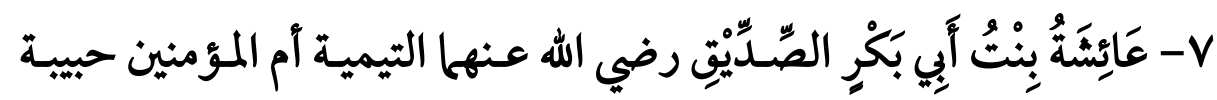
النبي صلى الله عليه وسلم، تزوجها رسول الله صلى الله عليه وسـلم بمكـة

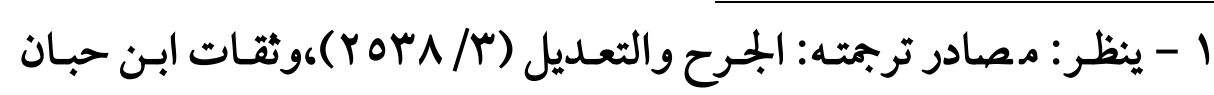

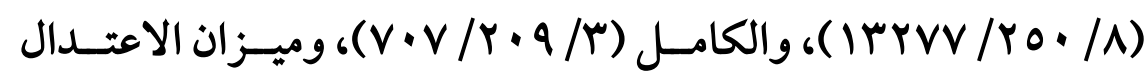

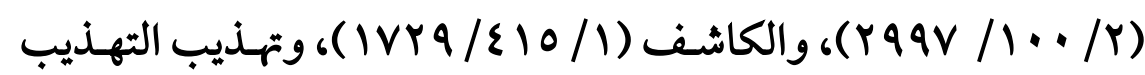

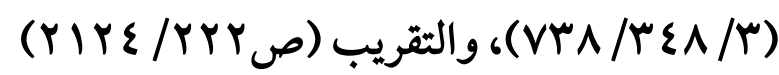

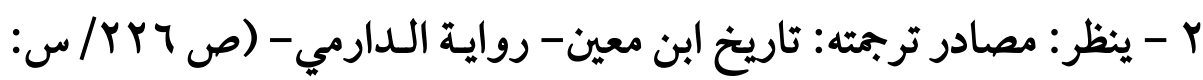

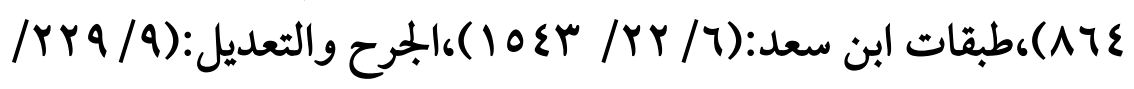
( ) (

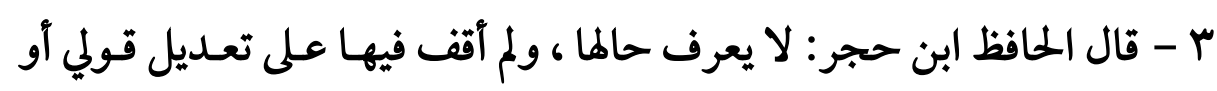

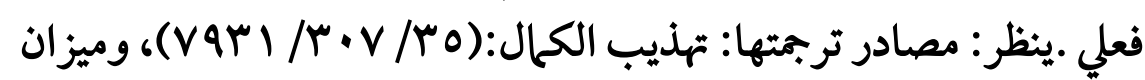

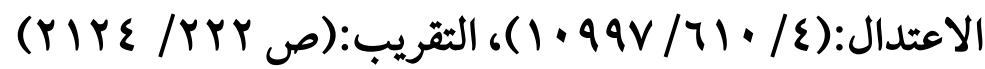


قبل المجرة بسنتين ،وهى بنت ست سنين، وبنى بها بالمدينة بعد منصرفه

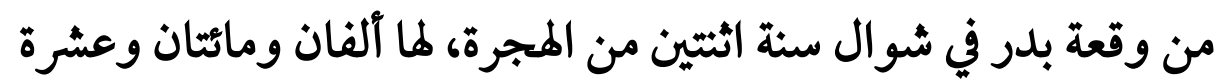

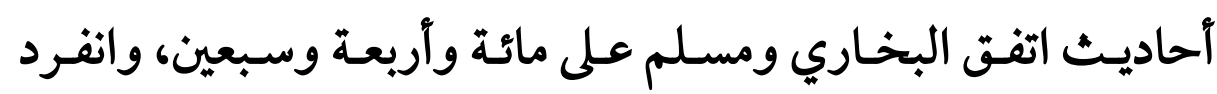

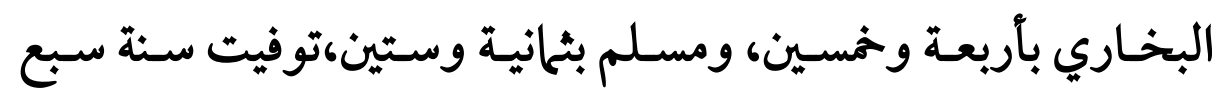
وخمسين ودفنت بالبقيع. (1) وللحديث شواهد لا تخلوا من ضعف في آسانيدها ؛ولذا حسن

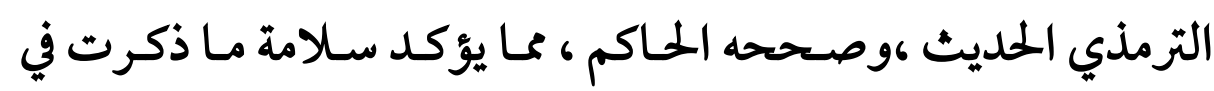
الترجمة الثانية ترجيح حال إبراهيم.

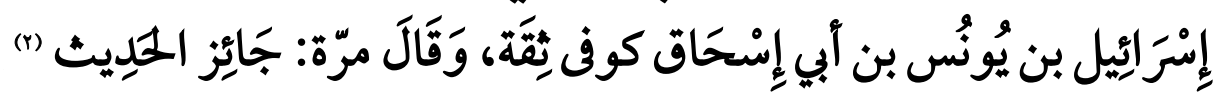

أقوال النقاد فيه:

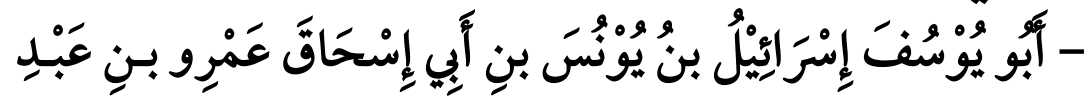

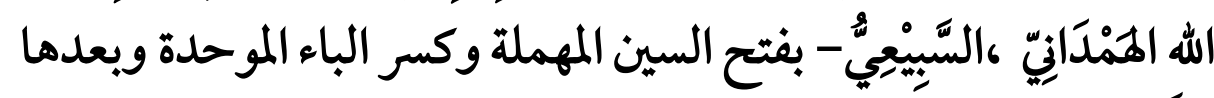

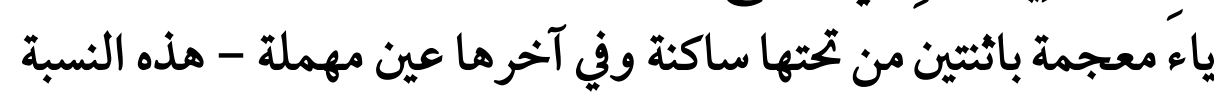

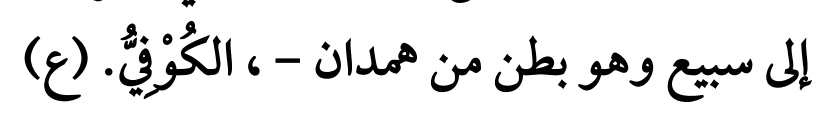

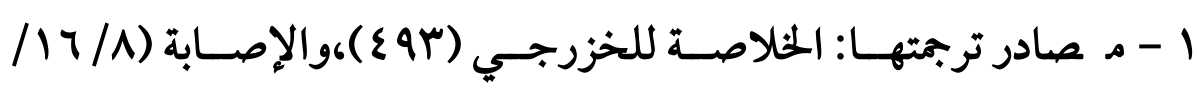

(I) $\varepsilon 0 \mathrm{~V}$

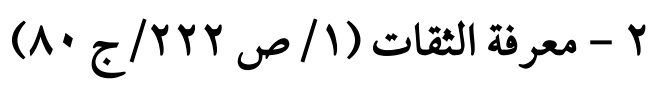


*روى عن: ميسرة بن حبيب ، والركين بن الربيع ، وإسـاعيل

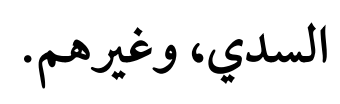

* روى عنه: الحسن بن عطية، وعبد الرمن بن مهدي، وعيسى

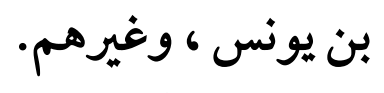

قال أبو حاتم : ثقة صدوق من من أتقن : أصحاب أبي إسحاق.وقال

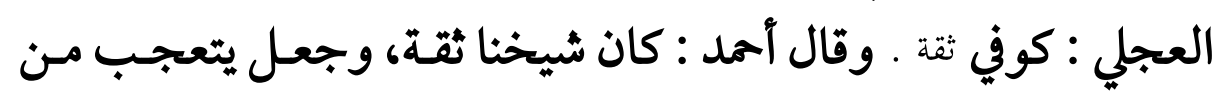

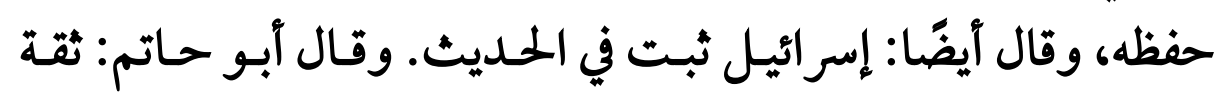

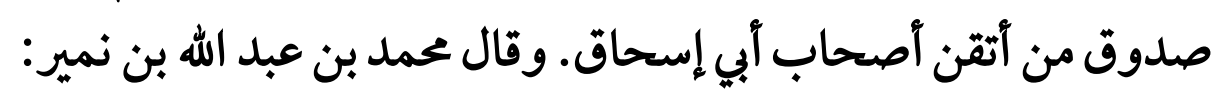

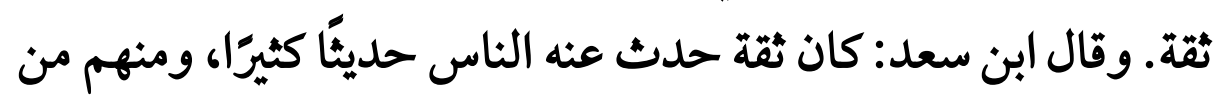

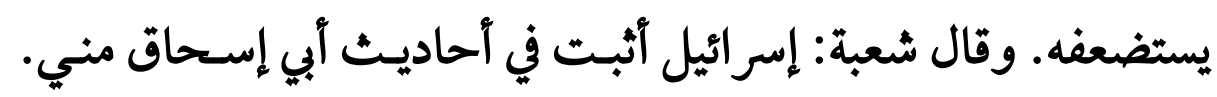

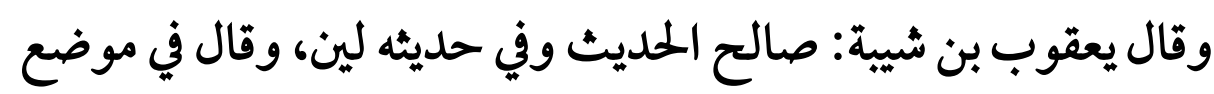
آخر: ثقة صدوق. وليس في الحديث بالقوي ولا بالساقط.

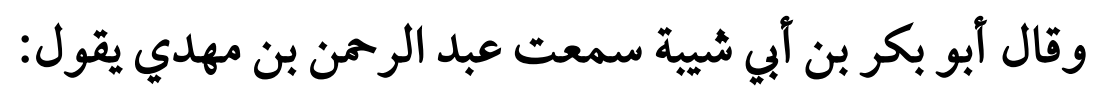

كان اسرائيل في الحديث لصا؟ يعني آنه يتلقف العلم تلقفا.

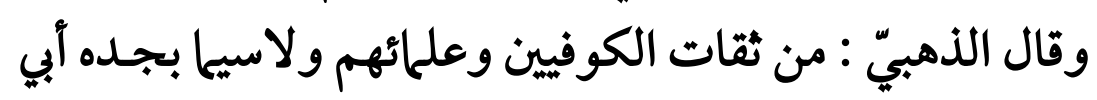
إسحاق، فإنه بصير بحديثه، احتج به الشيخان، ووثقه الناس .

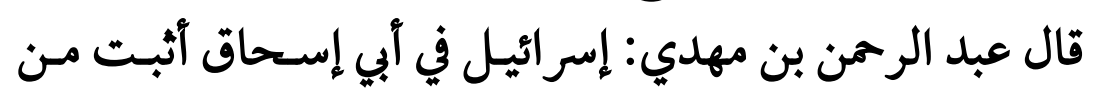
شعبة والثوري، يعني في أبي إسحاق. 
وقال حجاج الأعور قلنا لشعبة حـدثنا عـن أبي إسـحاق فقـال

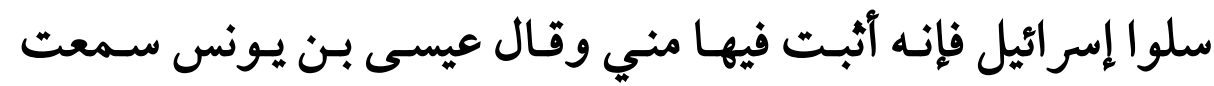

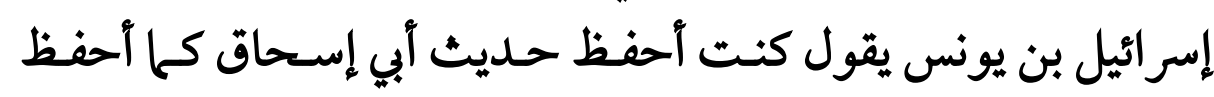
السورة من القرآن.

وقال أحمد كان القطان يحمل عليه في حال أبي يحيى القتات قال روى عنه مناكير.

وقد بين بن أبي خيثمة علة تضعيف القطان لإسرائيل، فقـال:

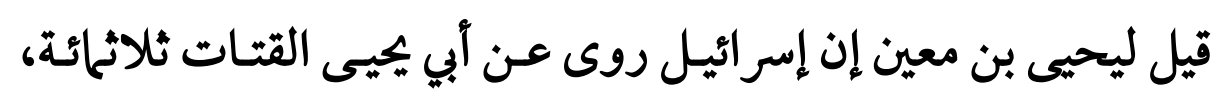

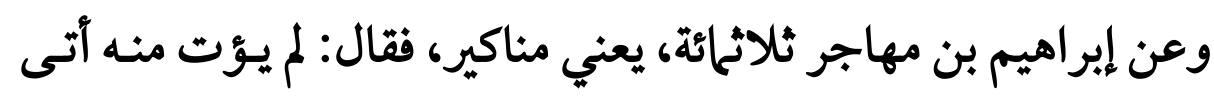

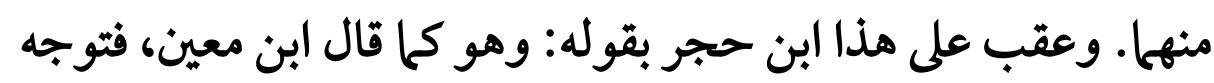

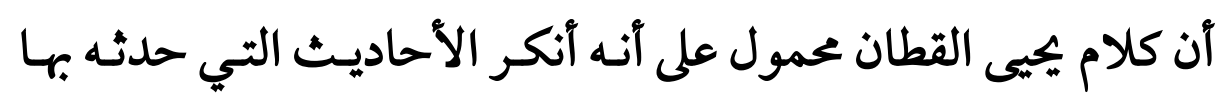

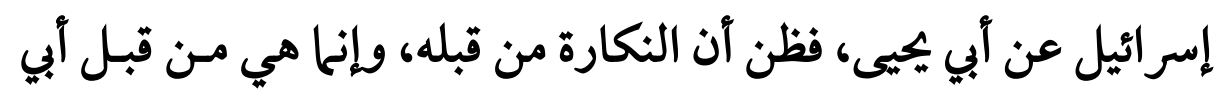

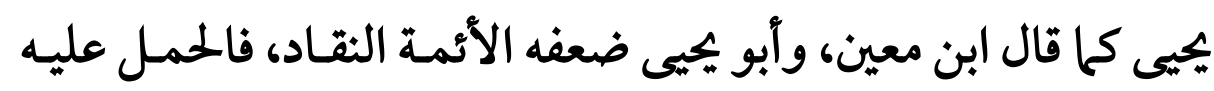

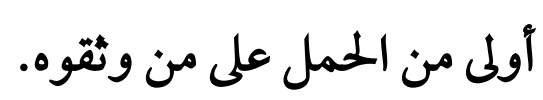

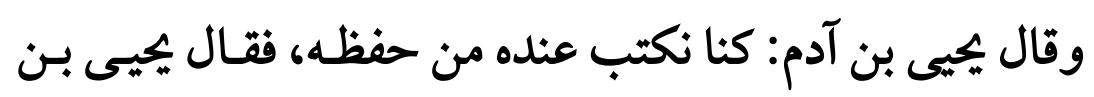

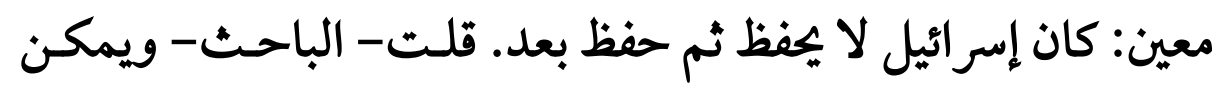
من خلال هذا الثقل الوقوف على سبب تضعيف من ضعفه من العلماء خلافا للجمهور. وقال النسائي: ليس به بأس. وقال ابن المديني: ضعيف. 
وعقب الذهبي- في السير - على قول ابن المديني بقوله: مشىى

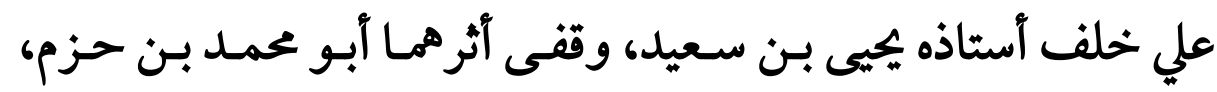

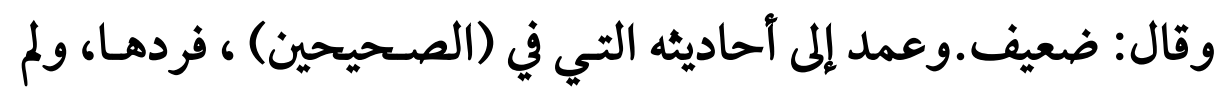

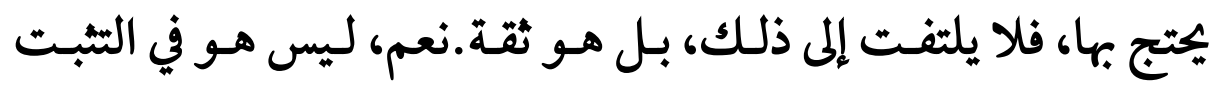

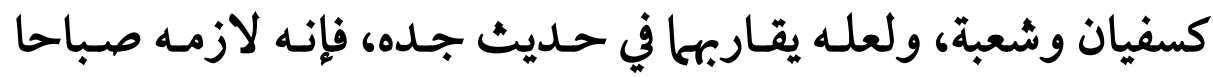

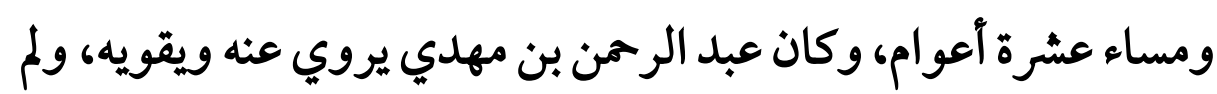
يصنع يجيى بن سعيد شيئا في تركه الرواية عنه، وروايته عن بجالد.

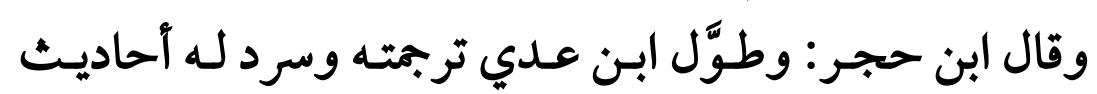

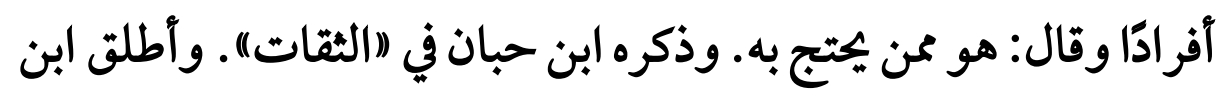

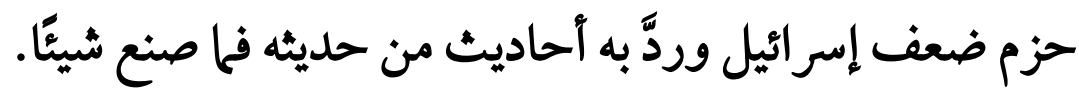

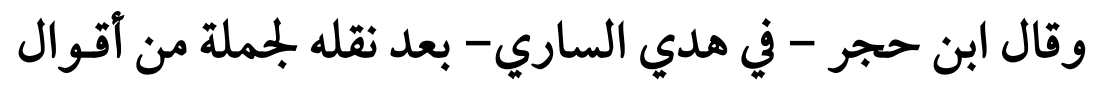
الموثقين: وبعد ثبوت ذلك، واحتجاج الشيخين به، لا يحمل من متأخر

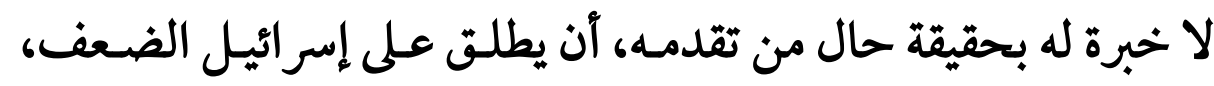
ويرد الأحاديث الصحيحة التي يرويها دائح)، لاستناده إلى كون القطان إنسان

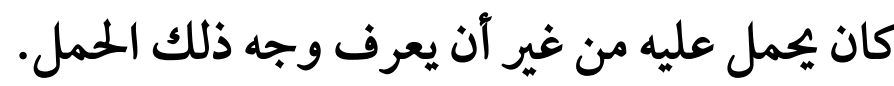

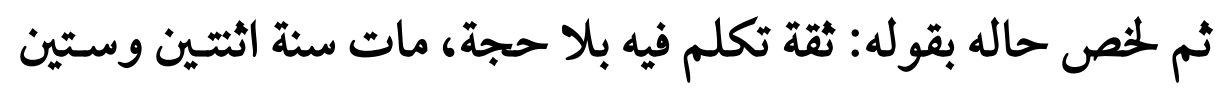
ومائة. (1).

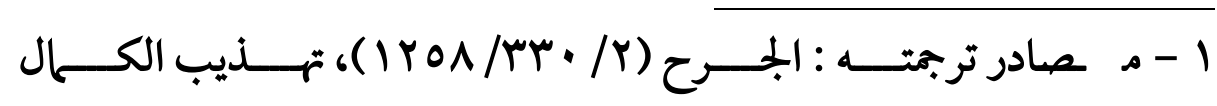

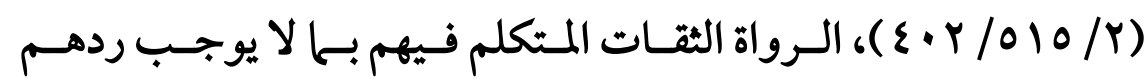




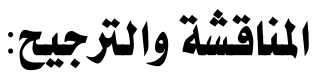

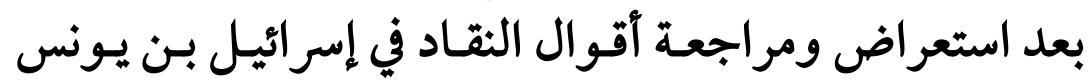

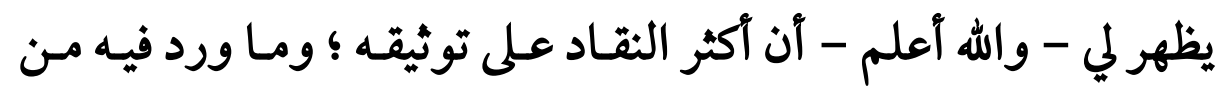
جرح فقد بين أهل العلم سببه وردوه ،ما يجعله بلا حجة معتبرة.

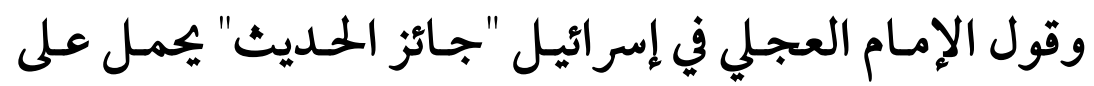
التوثيق المطلق ،ومما يدل على ذلك:

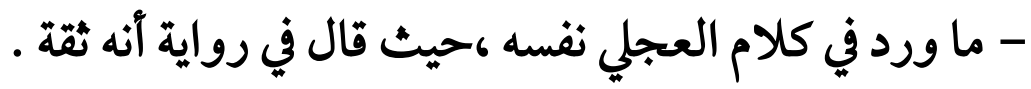

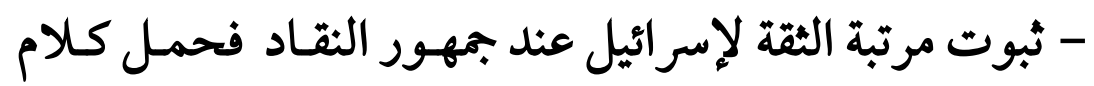

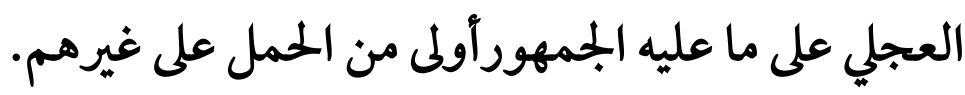

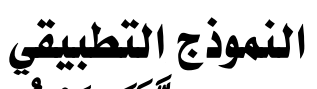

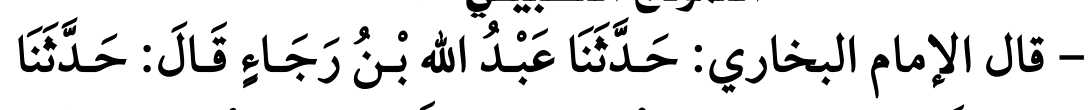

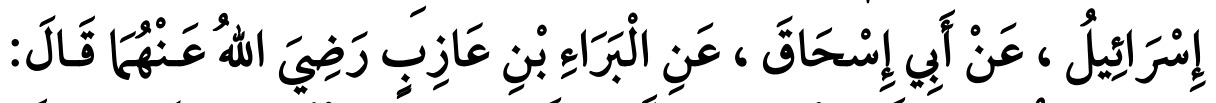

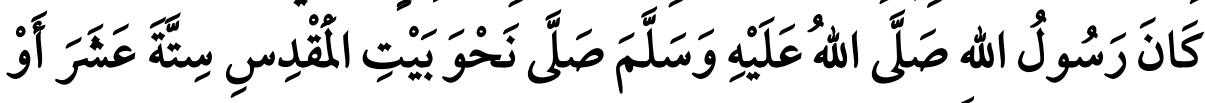

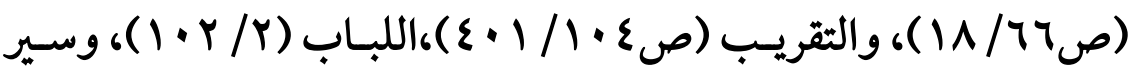

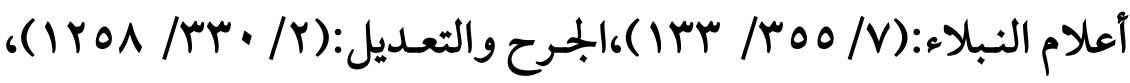

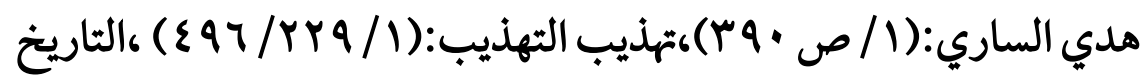

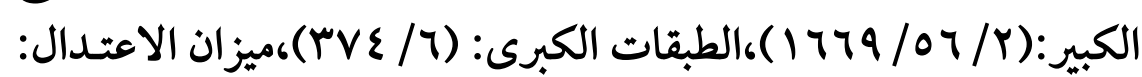

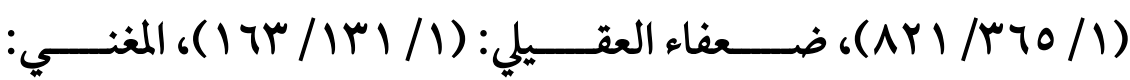




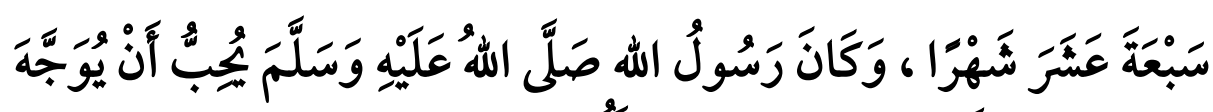

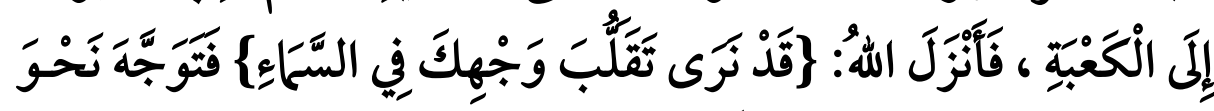

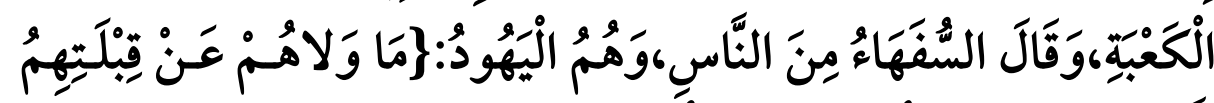

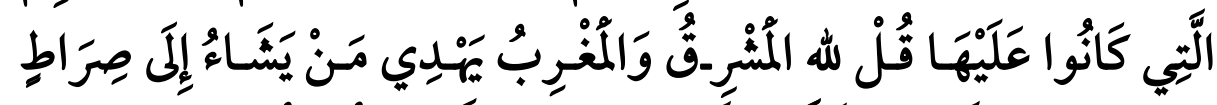

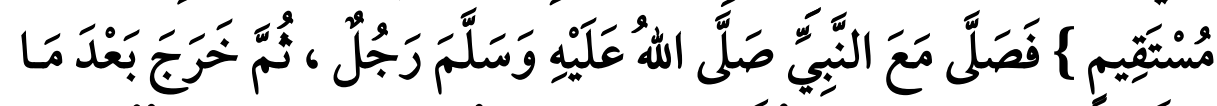

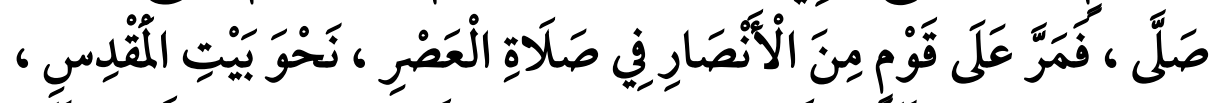

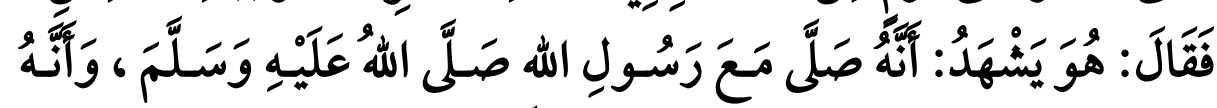

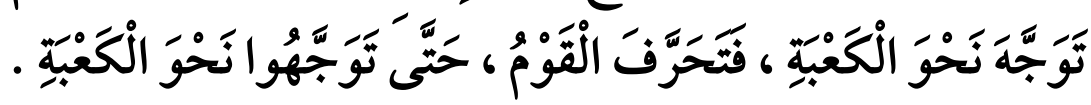

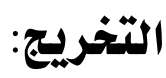

أخرجه البخاري في "صحيحه" في: كتاب الصلاة ، باب الثوجه

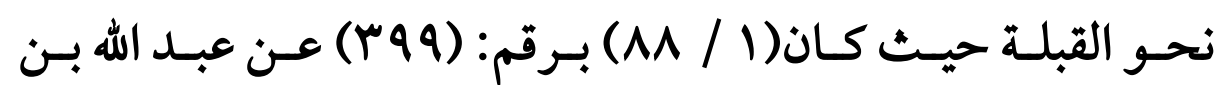

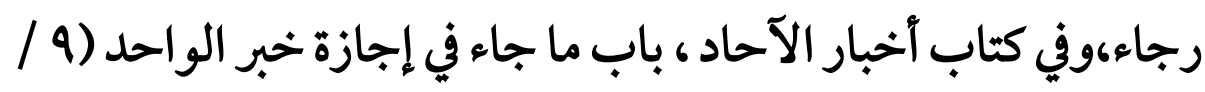

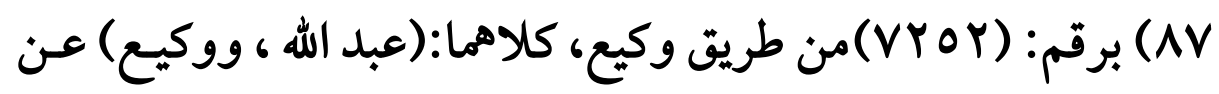

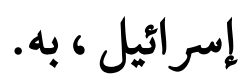
وأخرجه البخاري في "صحيحه" كتاب الإيلان ، بـاب الصلاة

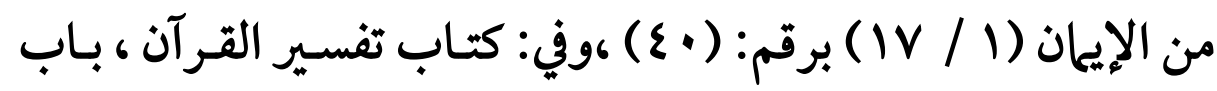

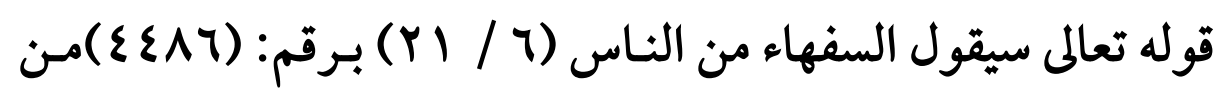

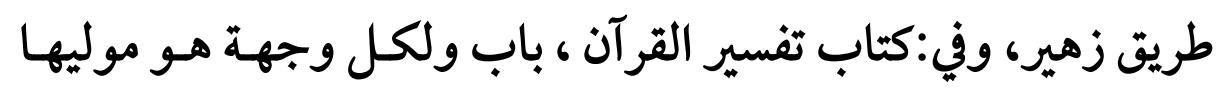

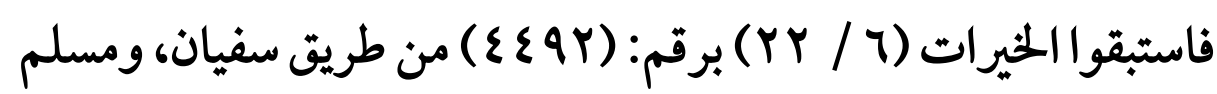

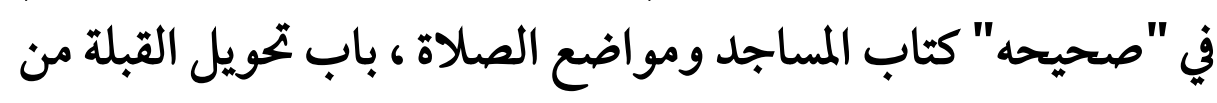




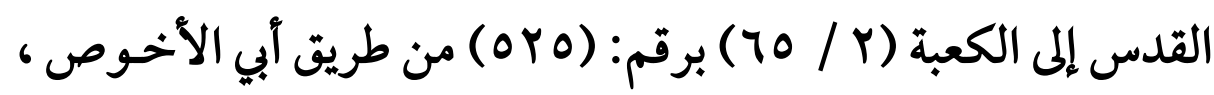

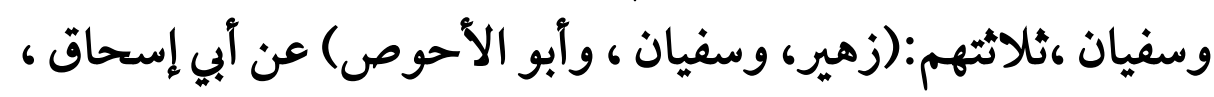

\section{التترجمة الثالثة}

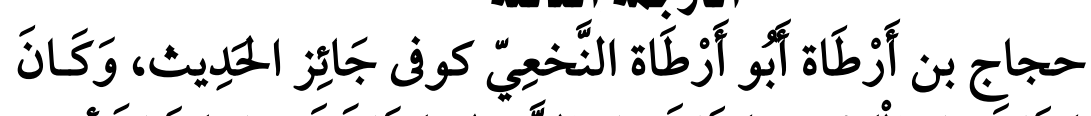

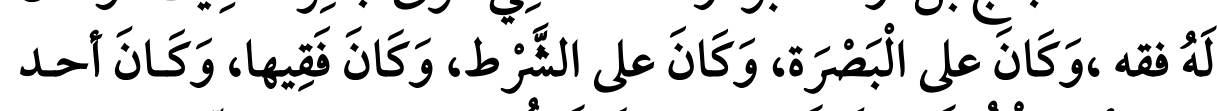

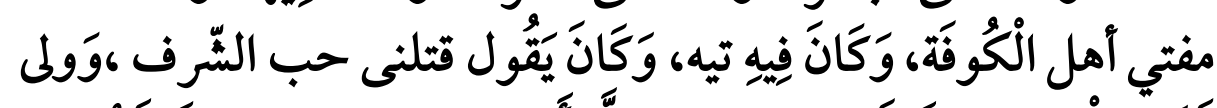

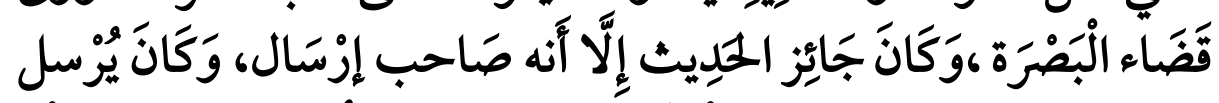

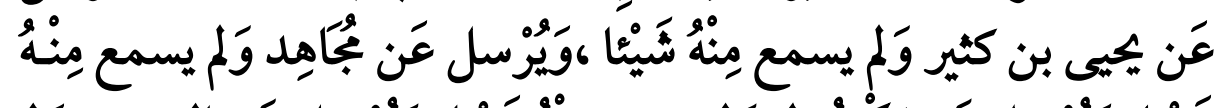

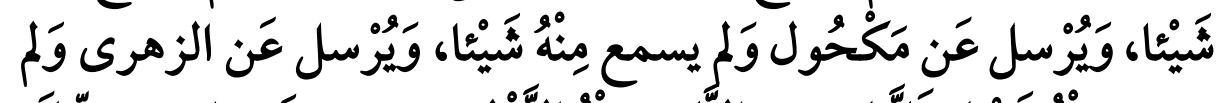

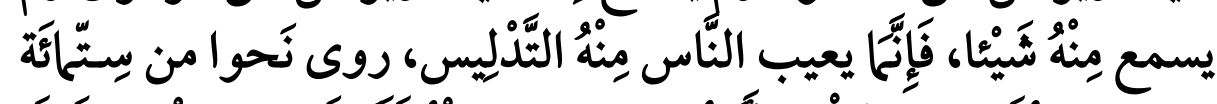

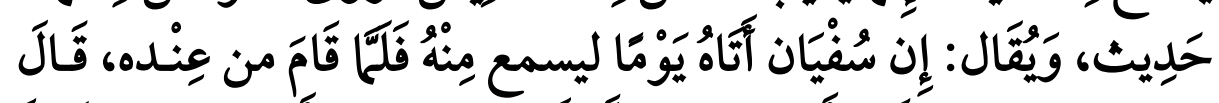

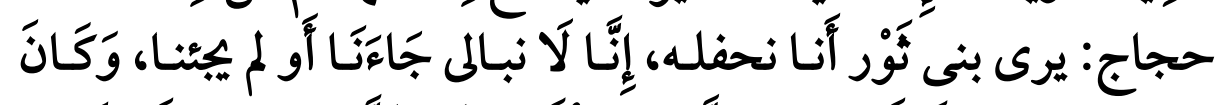

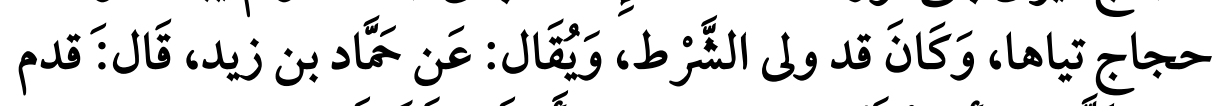

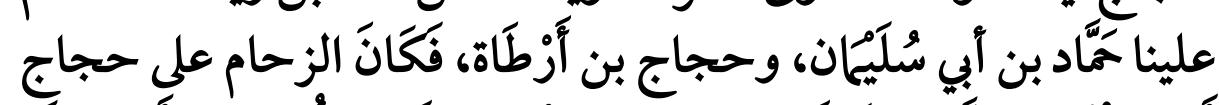

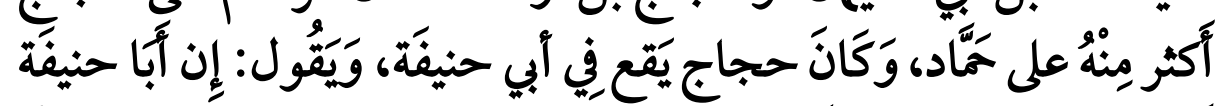

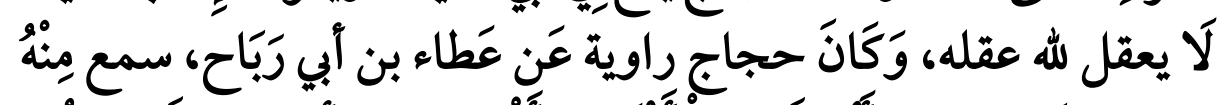

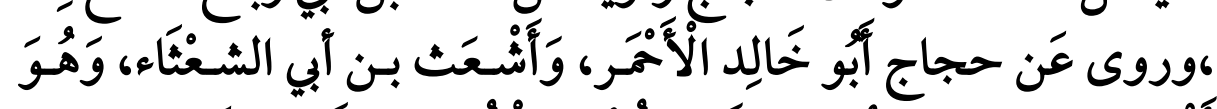

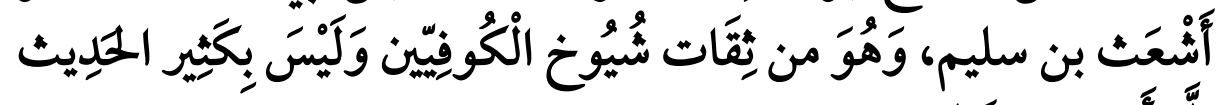

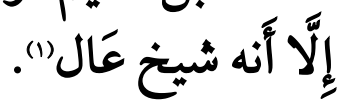

1 - معرفة الثقات (I/ص ع 


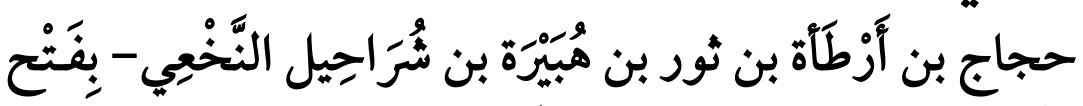

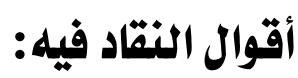

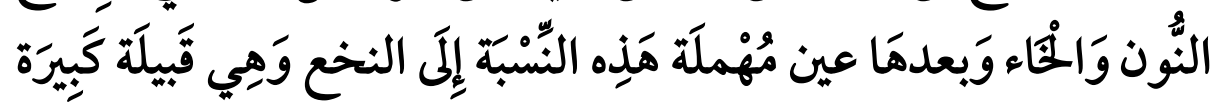
، أبو أَزٌَّْة الكوفي القاضي.

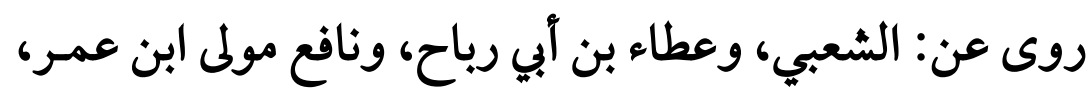

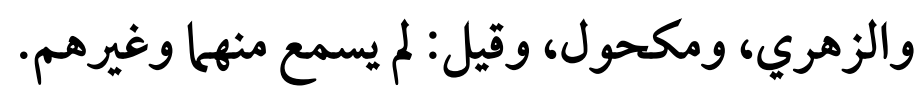

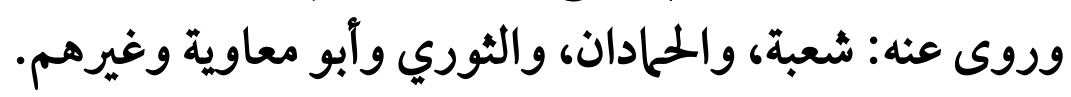

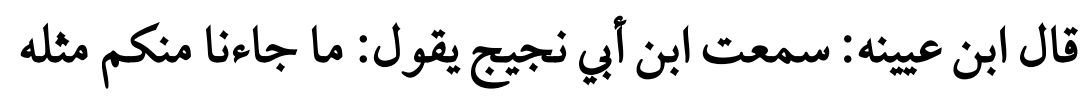

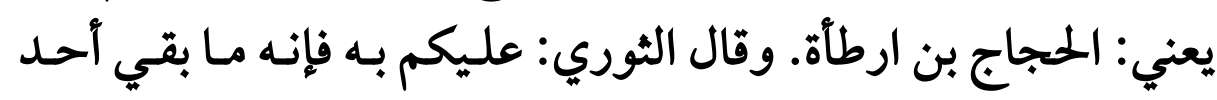

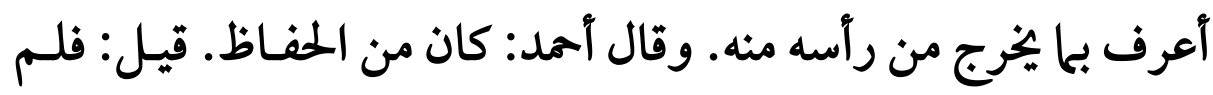

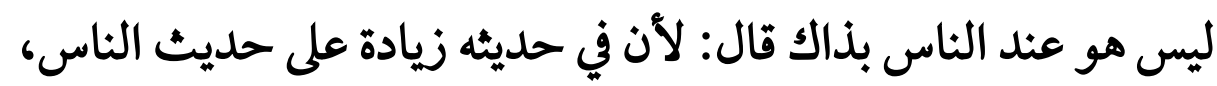

$$
\text { ليس يكاد له حديث إلا فيه زيادة. }
$$

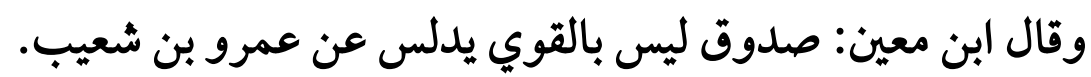

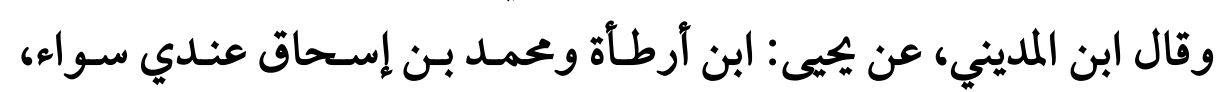

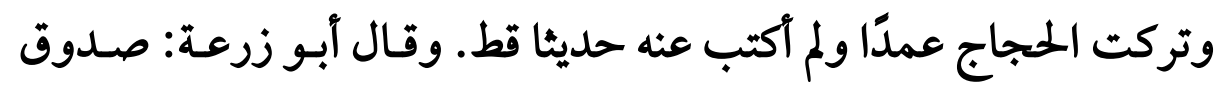

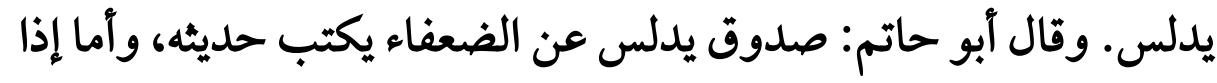

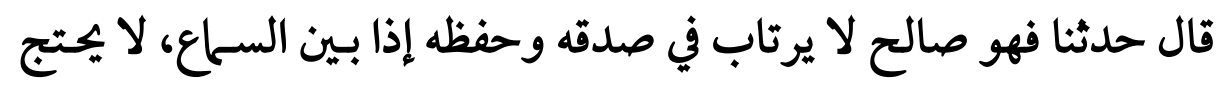

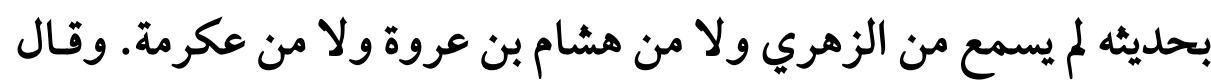
أبو داود: الحجاج سمع من مكحول. 
وقال الخليلي: عالم ثقة كبير، ضعفوه لتدليسه. وقال أبو حساتم

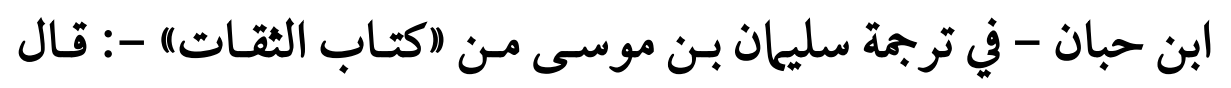

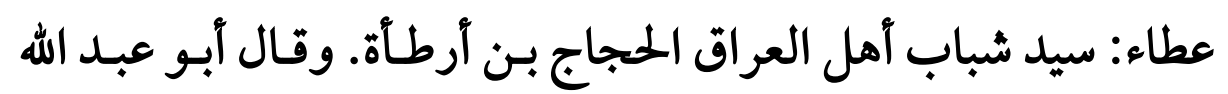

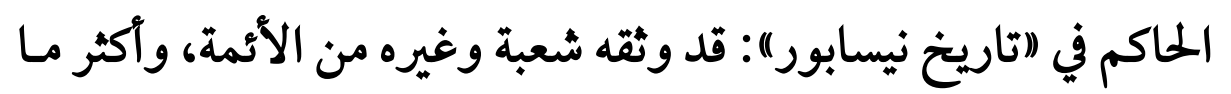

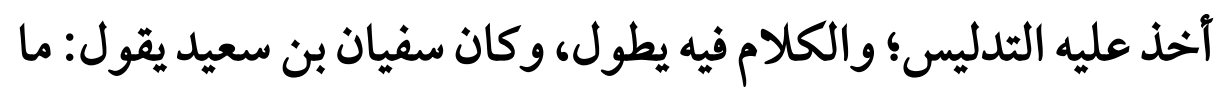

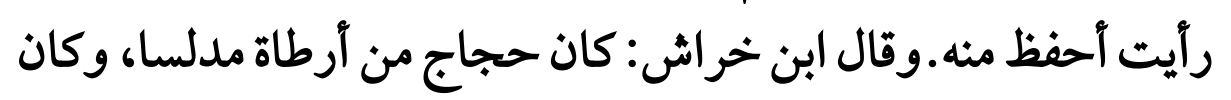

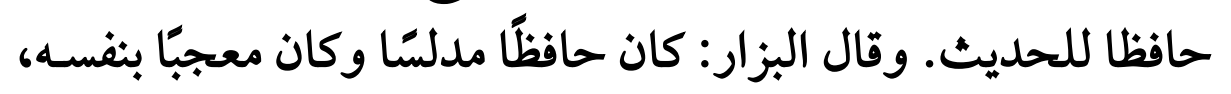

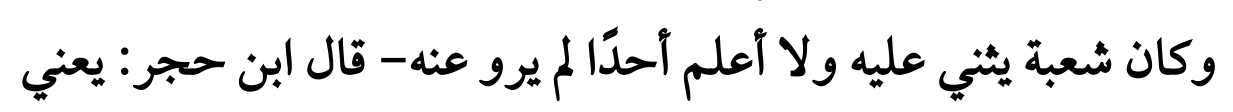
من لقيه- الا عبد الله بن إدريس. وفي (اكتاب) ابن أبي خيثمة عن يحيى بن معين: ليس هو من أديد آهل

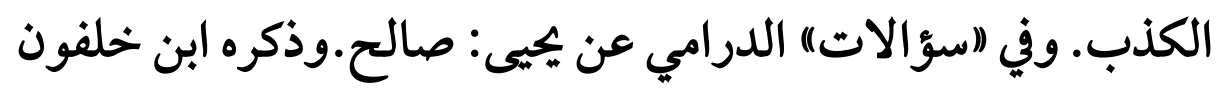
في (الثقات) وقال: هو عندهم صـدوق. وقال البخـاري في "(التاريخ

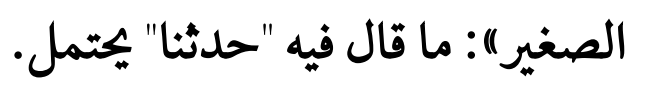

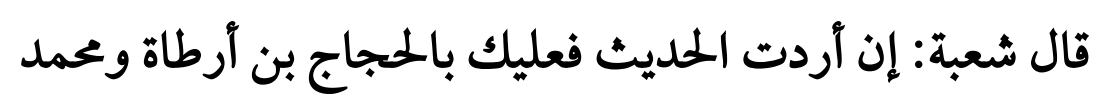
بن إسحاق. وقال : اكتبوا عن حجاج وابن إسحاق ، فيإنها حافظان. حفص بن غياث قال:سمعت سفيان الثوري يقـول: مـا تأتون أحسدا أحفظ من حجاج بن أرطأة. وقال يحي بن آدم، حدثنا حماد بن زئ زيد قال: حجاج أسد حديثا من سفيان الثوري. 


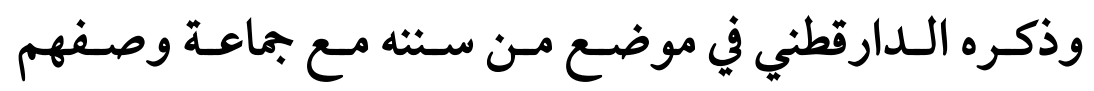

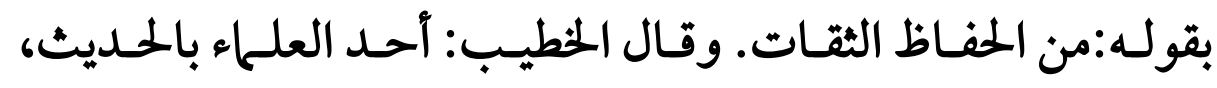

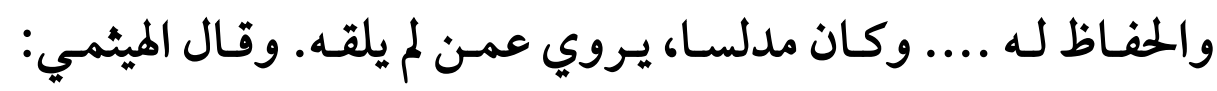
مدلس صدوق،يكتب حديثه، وليس ممن يتعمد الكذب ، وقال: هو ثئة

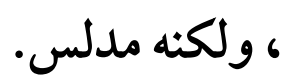
وقال هشيم: قال لي الحجاج بن أرطأة: صف لي الزهري فإني لم

وقال الإمام أمد فيها حكاه ابنه: هو مضطرب الحلديث.وقال:

كان يروي عن رجال لم يلقهم. وكأنه ضعفه. وقال البهال البخاري في في التاريخه

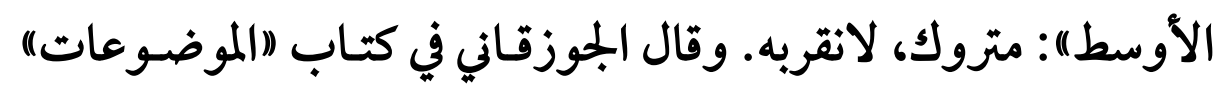
تأليفه: ضعيف. وقال منصور: الحجاج، كتب عنه على الحتى سبيل الإنكار.

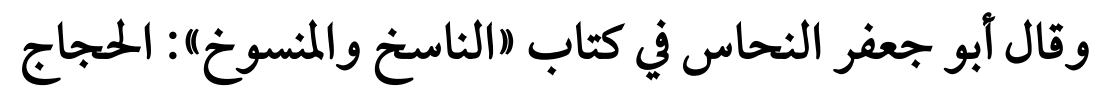

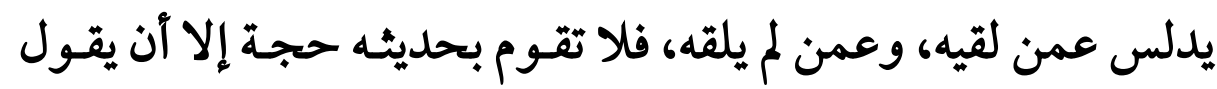

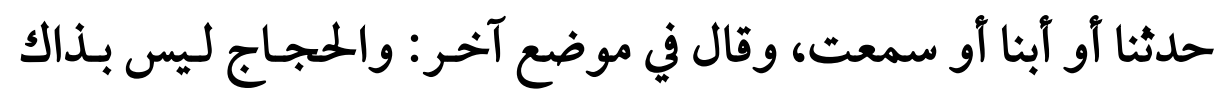

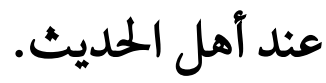

وقال ابن معين: صدوق وليس بالقوي في الحديث ،وقال مرة:

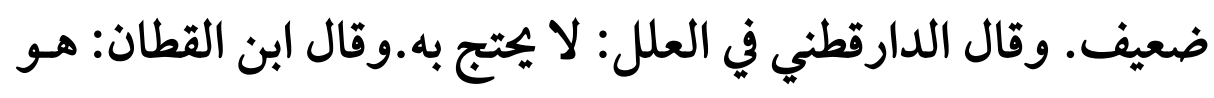
دائم يضعفه ويضعف به، والحوض فيه طويل. 
وقال ابن سعد: كان شريفًا وكان ضعيفًا في الحديث. وقال أبـو

أحمد الحاكم: ليس بالقوي عندهم. وقال مسعود السجزي عن الحاكم:

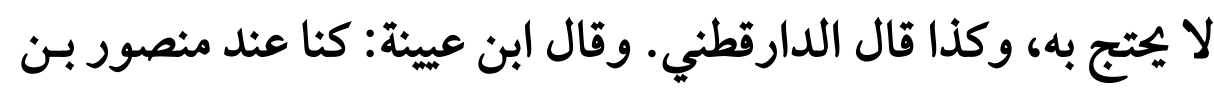

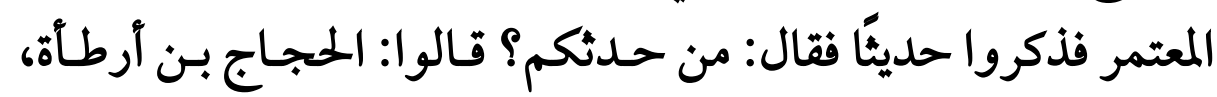

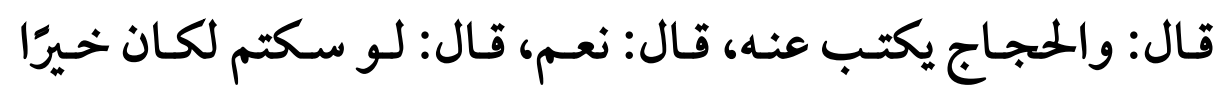

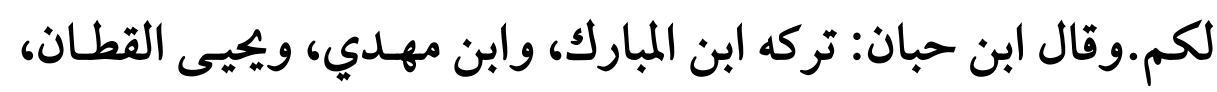
وييحى بن معين، وأحمد بن حنبل.

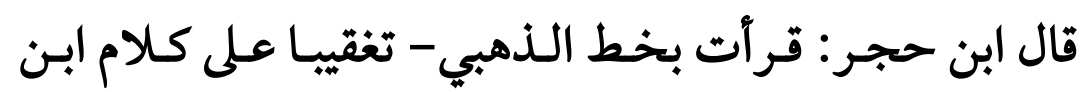
حبان- هذا القول فيه بجازفة وأكثر ما نقم عليه التدليس وكان فئ فيه تيه لا

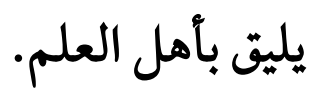
وقال أبو بكر بن خزيمة، لا أحتج به إلا فيها قال أنبا آو سمعت. وذكره أبو القاسم البلخي، وأبو جعفر العقيلي، وأبو محمد بن الجمارود

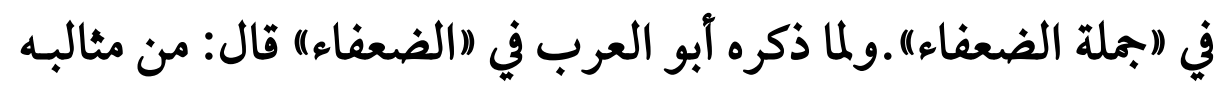

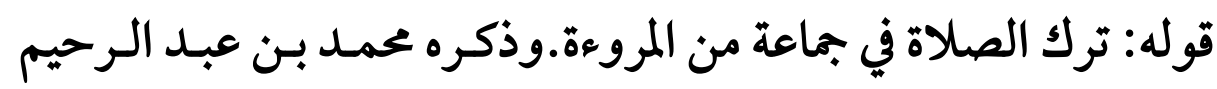
البرقي في (باب: من نسب إلى الضعف) .وقال له داود الطائي يوما: إني

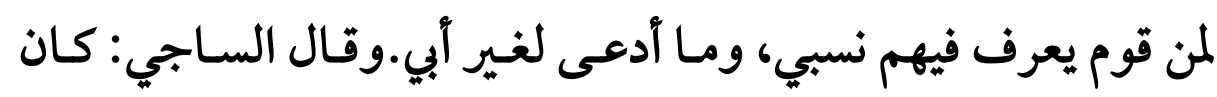

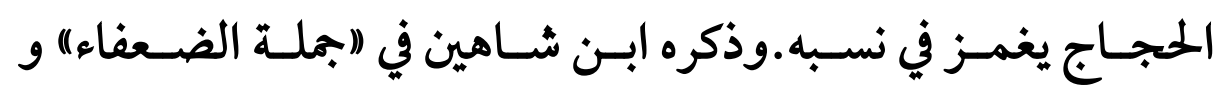

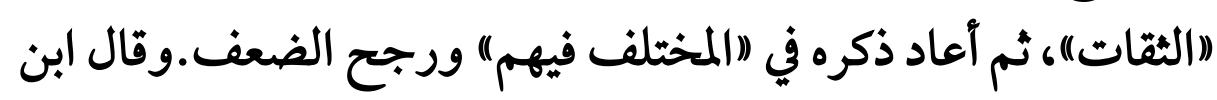

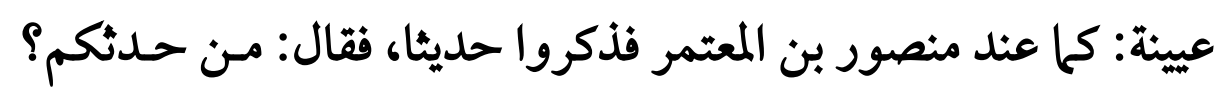


قالوا: حجاج بن أرطاة. قال: والحجاج يكتب عنه؟ قالوا: نعم.قال: لو

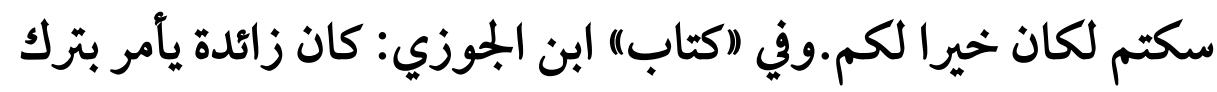
حديثه.وقال النسائي: ليس بالقوي،ورقال: ضعيف لا يحتج به،وذكره في

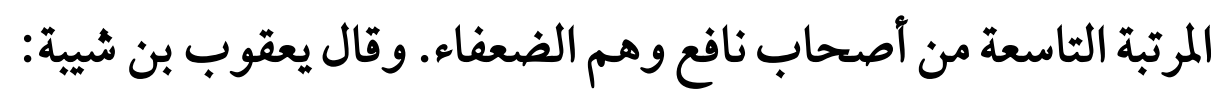

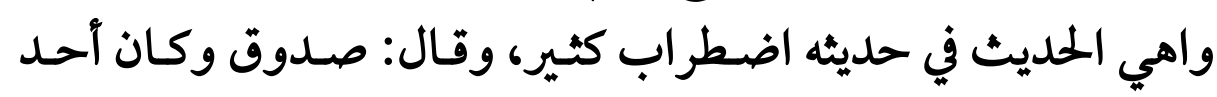

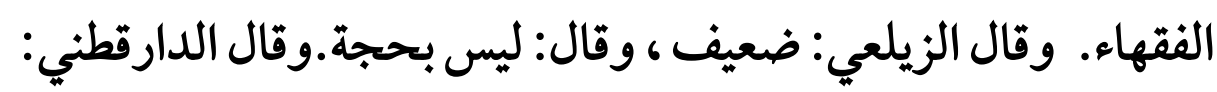

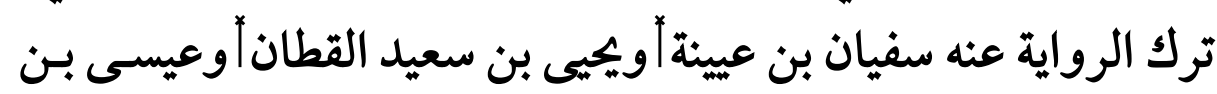

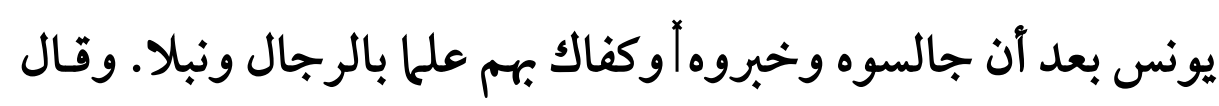

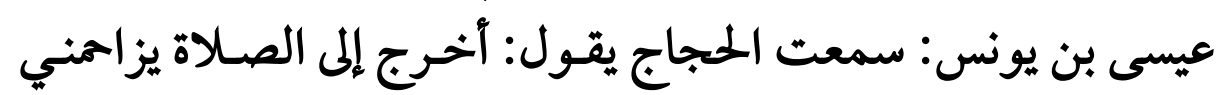

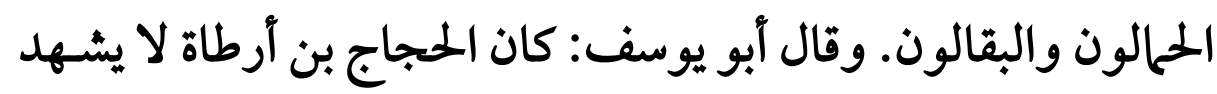
جمعة ولا جماعة ويقول: أكره مزاحة الأنذال.

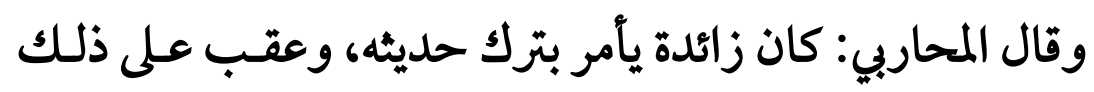

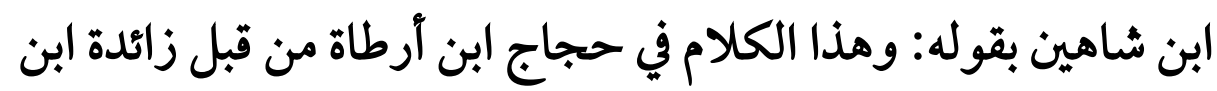
قدامة عظيم وقد وافقه على ذلك يميى بن معين في أحد قوليه، وأما مـا

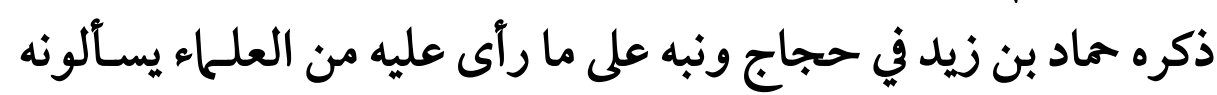

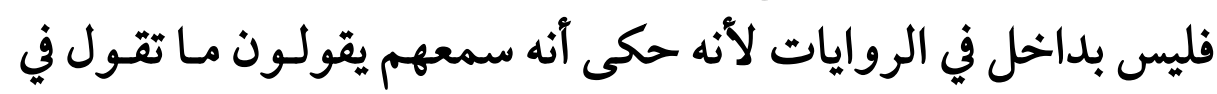

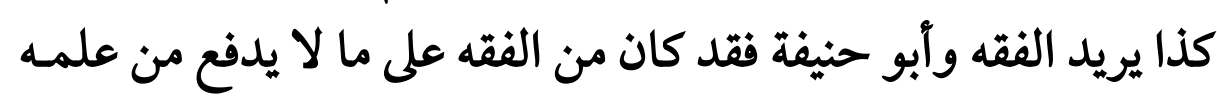

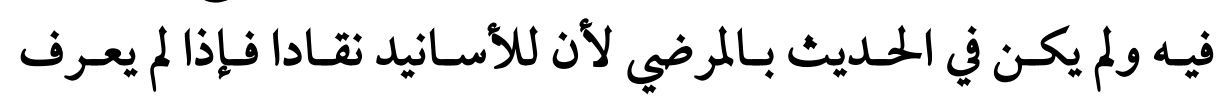
الإنسان ما يكتب وما يحدث به نسب إلى الضعف والله أعلم بذلك. 
وقال ابن المديني: قال علي: لم يحمل يميى - القطان- عن حجاج

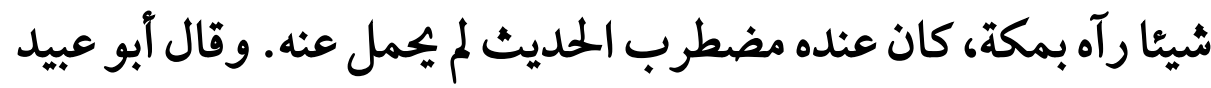

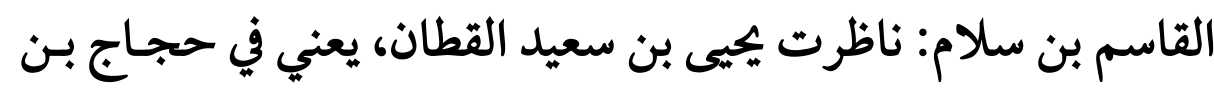

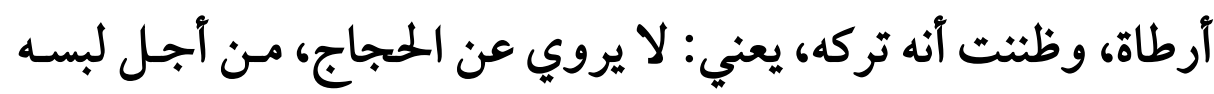

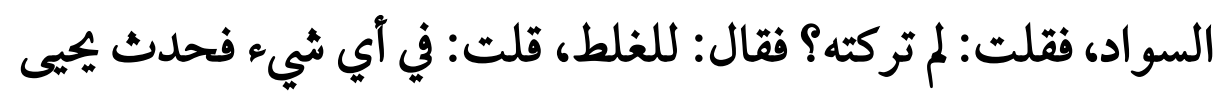
بغير حديث.

وقال إسهاعيل القاضي:مضطرب الحديث لكثرة تدليسه. وقال ابن حزم: ساقط لا تحل الرواية عنه، وقال: هالك.

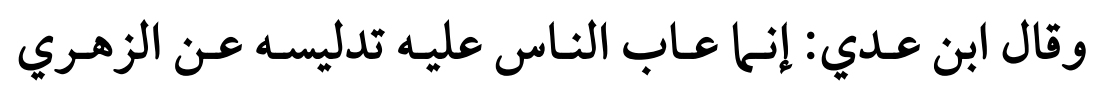

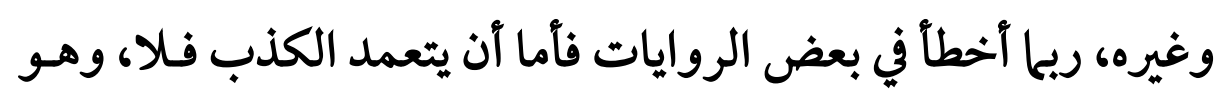

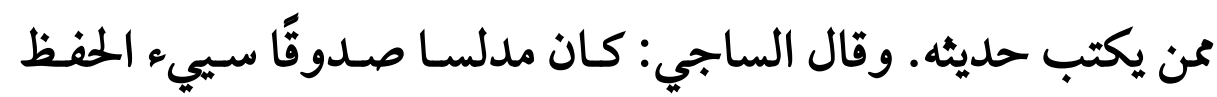
ليس بحجة في الفروع والآحكام.

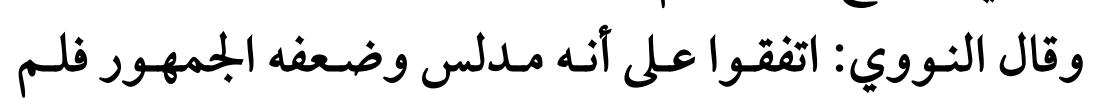
يحتجوا به، ووثقه شعبة وقليلون وكان بارعا في الحفظ والعلم.

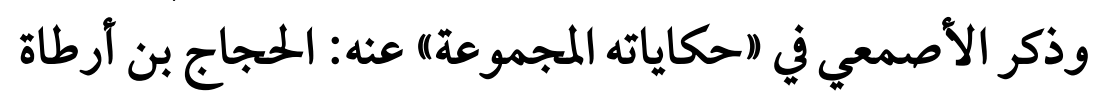

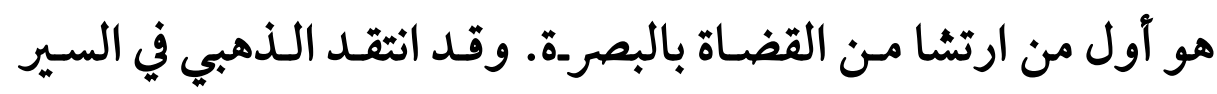
تصحيح الترمذي لحجاج ، وقال : ليس بجيد. 
وقال الذهبي: أحد الاعلام على لين فيه. وقال ابن حجر: أحد الفئه الفهاء

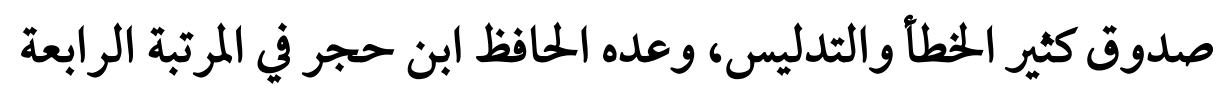
من مراتب المدلسين. (1)

بعد استعراض ومراجعة أقوال النقاد في حجاج بن أََّّْاة يظهر

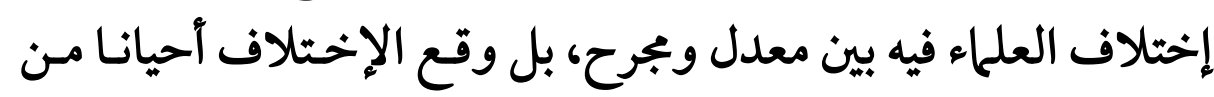
الإمام الواحد، ومرد ذلك للفرق في الحكم عليه بين ما عنعن فيه وما فيا

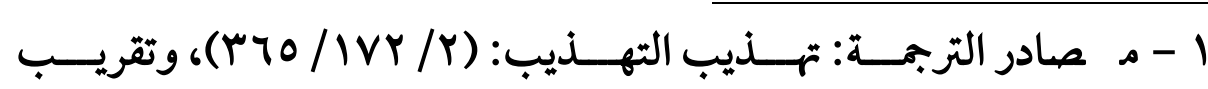

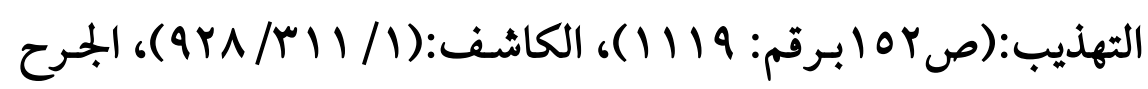

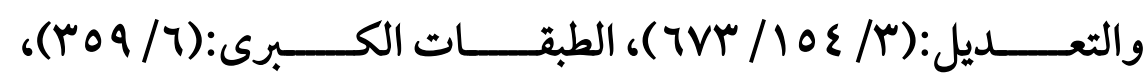

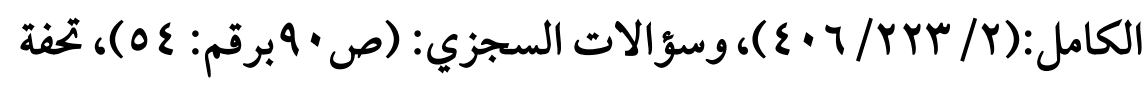

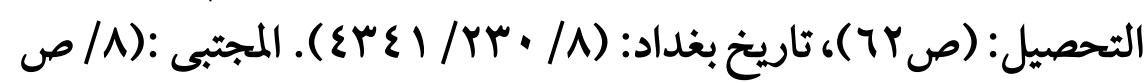

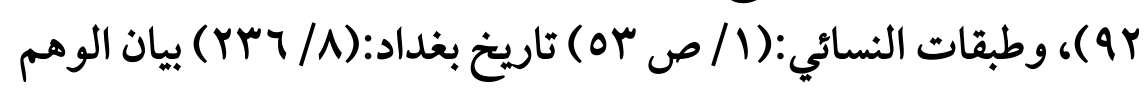

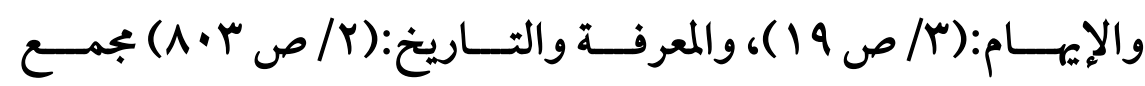

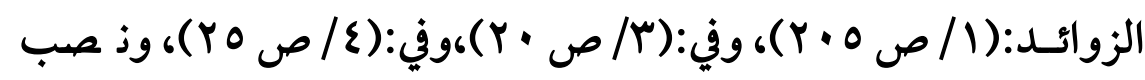

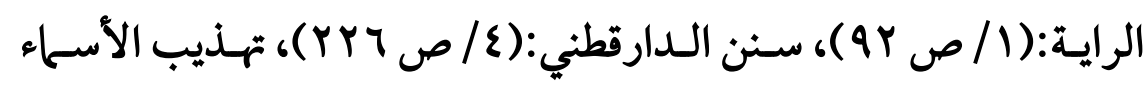

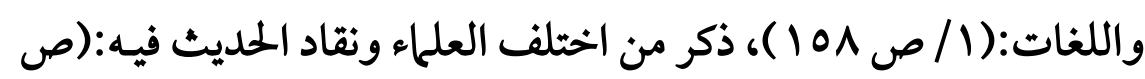

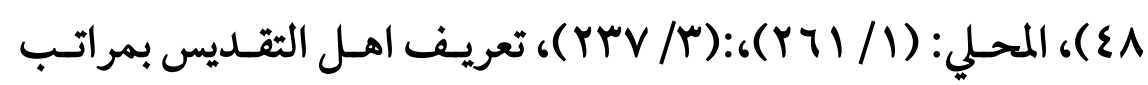

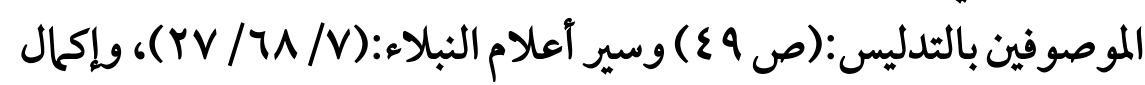

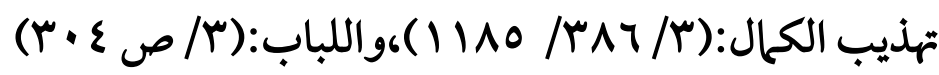


صرح فيه بالتحديث، وذلك لما اشتهر عنه من التدليس والإرسال ،ولذا

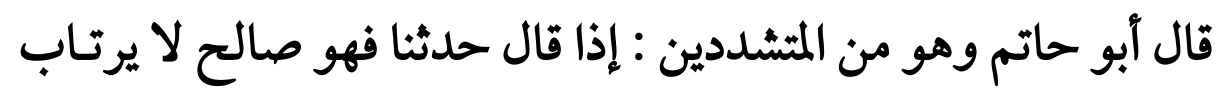

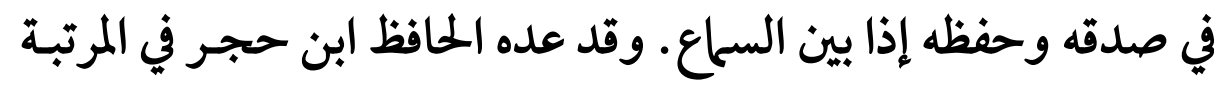

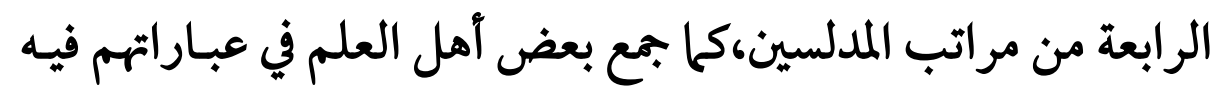

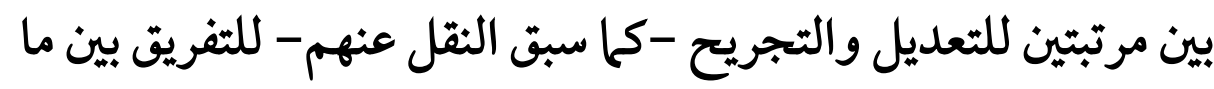
صرح فيه بالتحديث ويين ما عنعن فيه. وعليه يمكن تلخيص حاله: بأنه صدوق فيه فيها صيا صرح فيه بالتحديث

$$
\text { ضعيف كثير الخطأ فيها عنعن فيه. }
$$

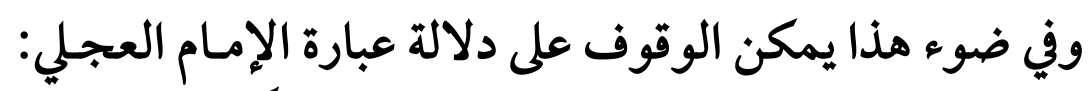

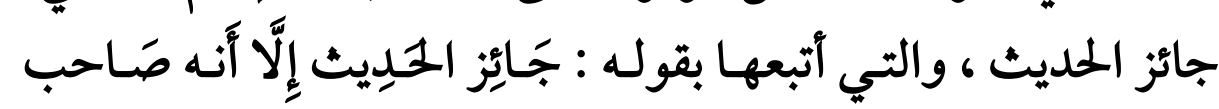

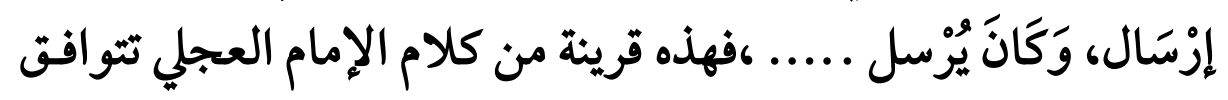

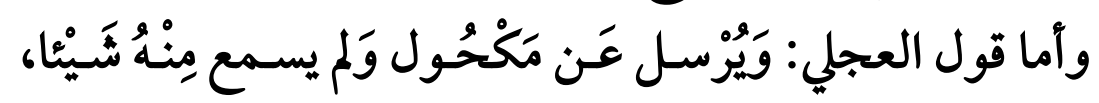

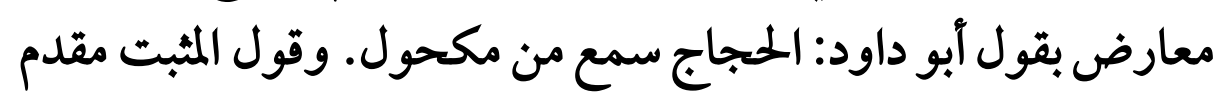

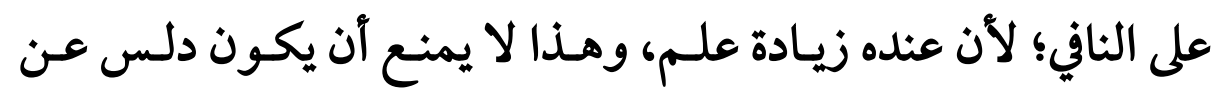

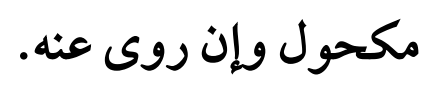

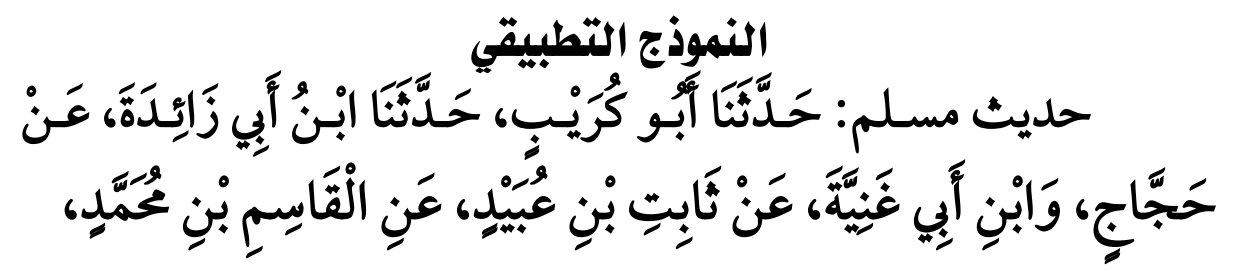




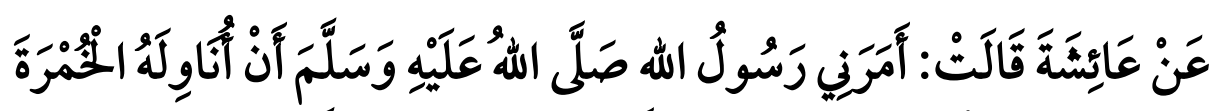

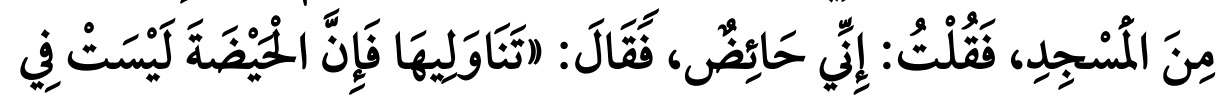

أخرجه مسلم في "صحيحه" كتاب الحيض ، بـاب جـواز غسل

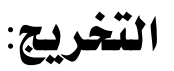

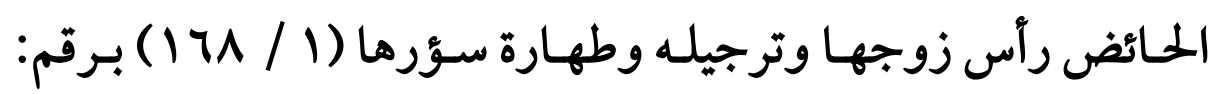

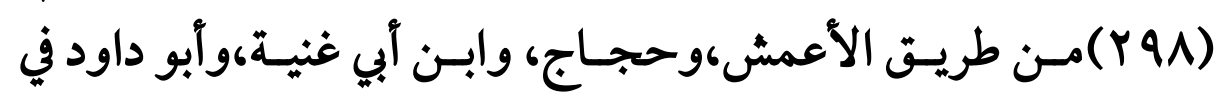

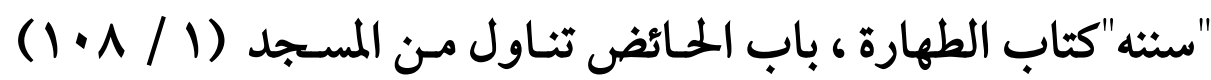

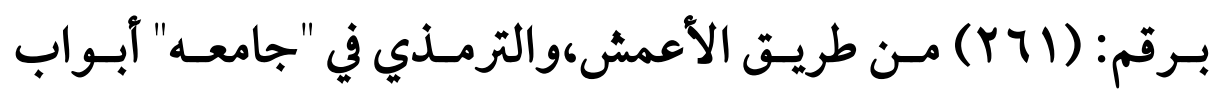

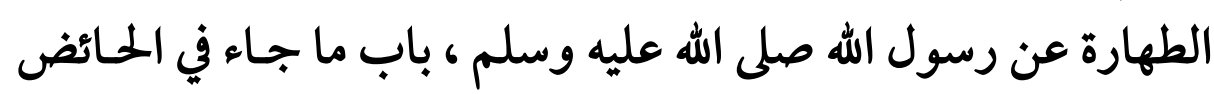

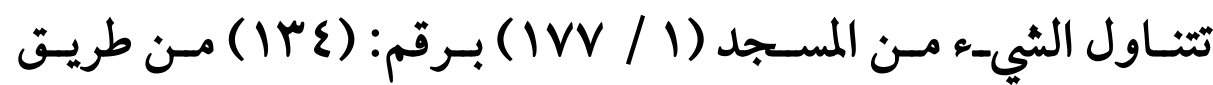

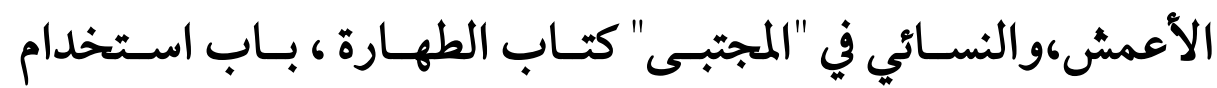

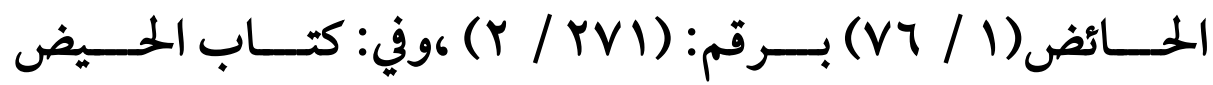

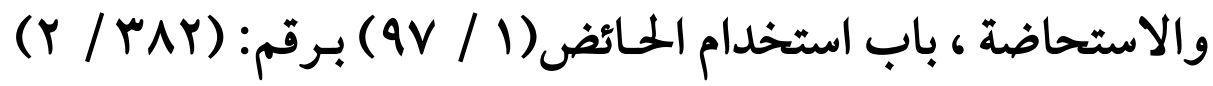

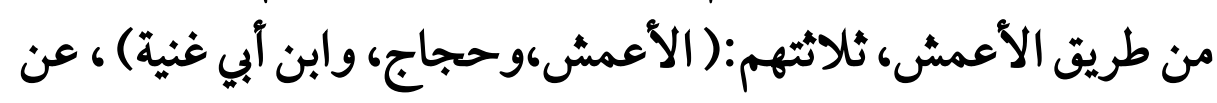

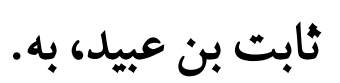
وقال الترمذي: حديث عائشة حديث حسن. 


\section{التزجمة الرابعة}

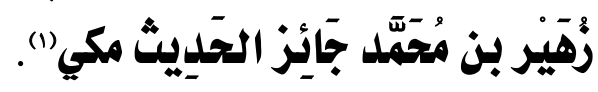

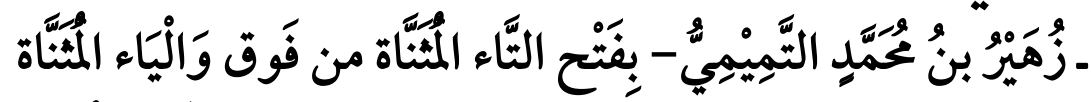

أقوال النقاد فيه:

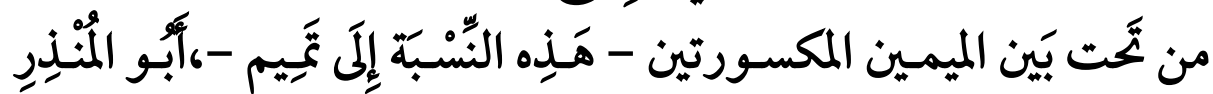

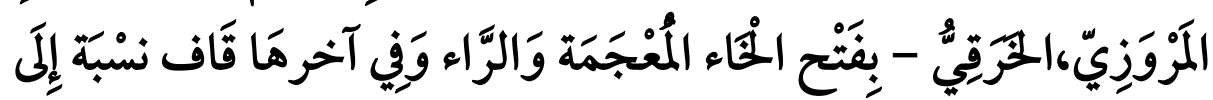

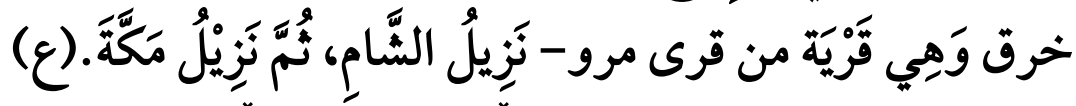
روى عن: عاصم الأحولأ وزيد بن آسلم|ّوغير هما. روى عنه: أبو داود الطيالسيأوأبو عامر العقديأوغير هما.

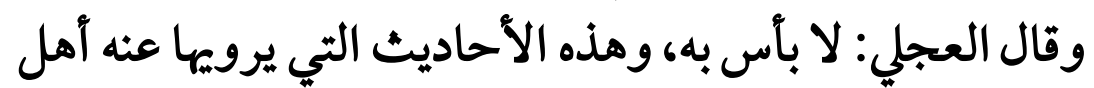

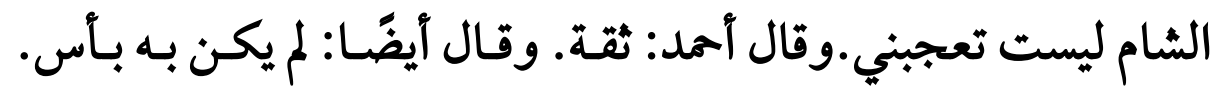

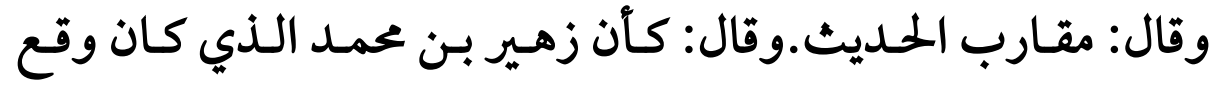

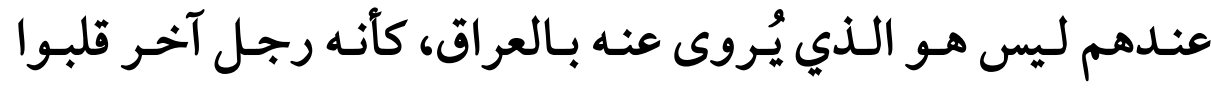

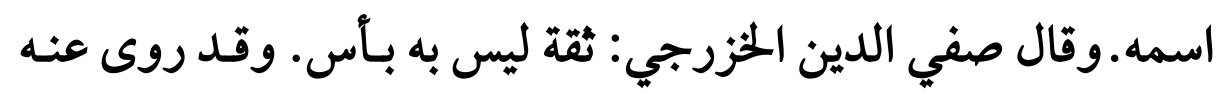
ابن مهدي، وكان لا يروي إلا عن ثئة.

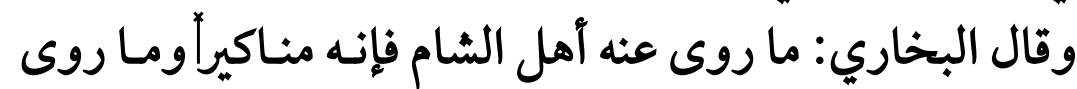

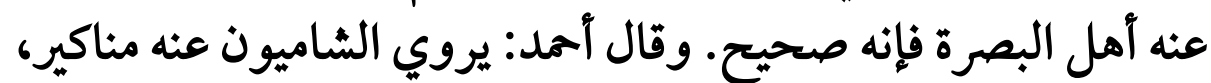

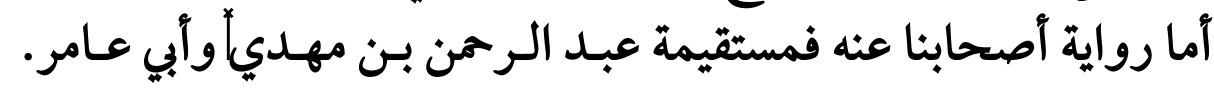

$$
1 \text { - معرفة الثقات (1/ص آV/ ج r (0) }
$$




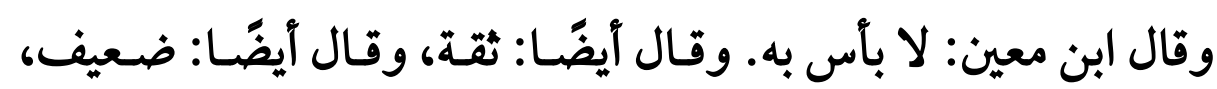

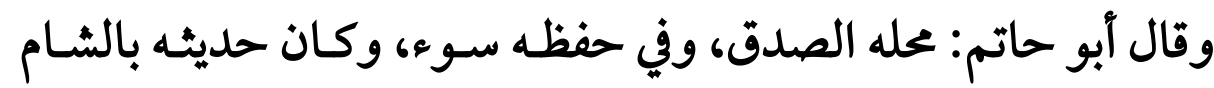

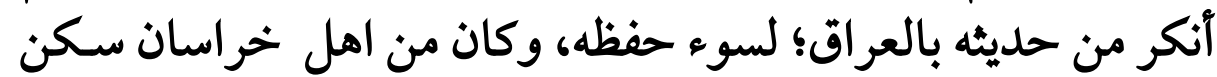

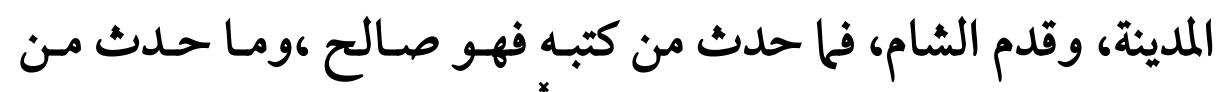

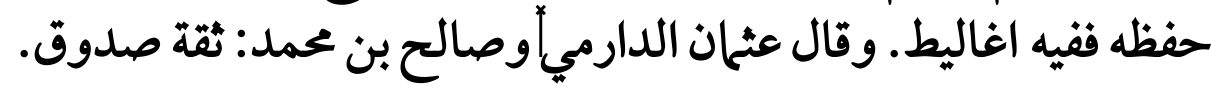

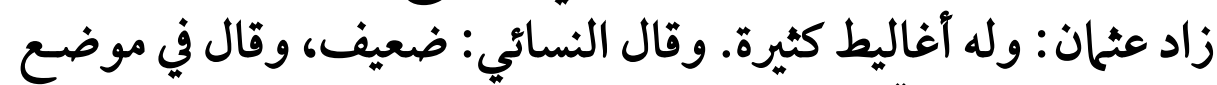

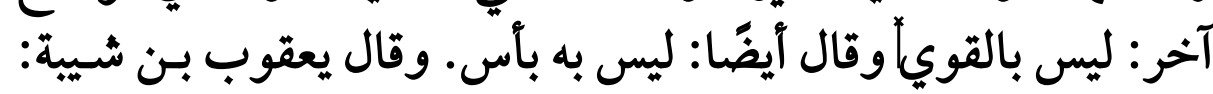

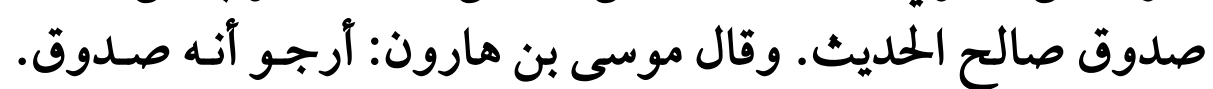

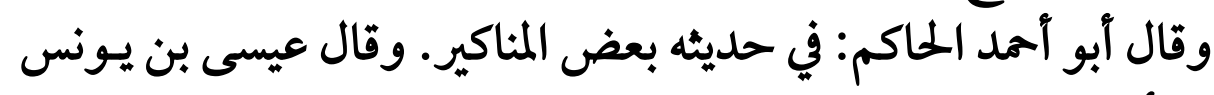

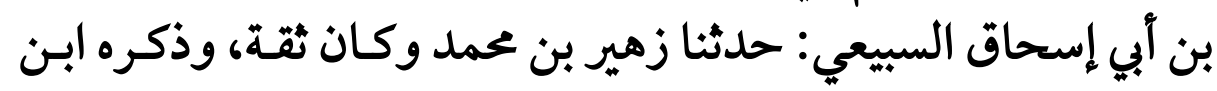

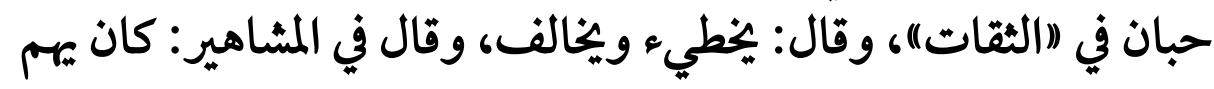

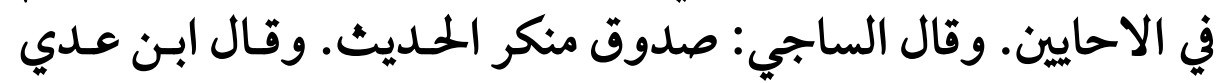

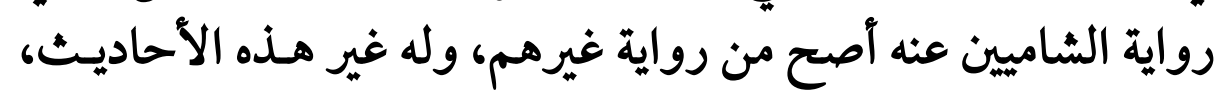

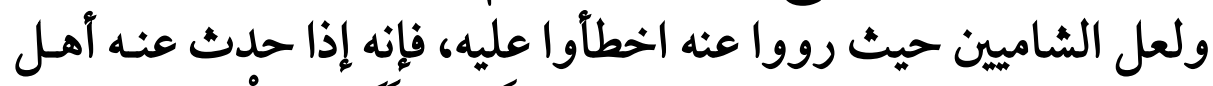

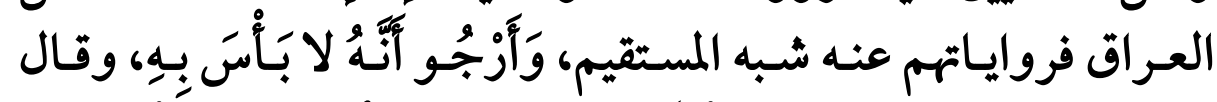

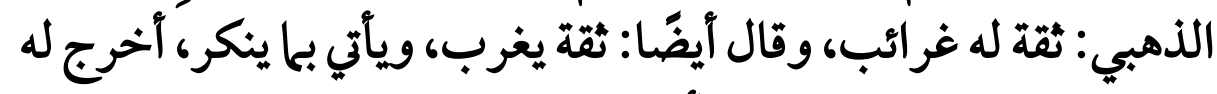

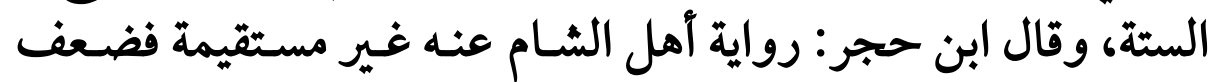

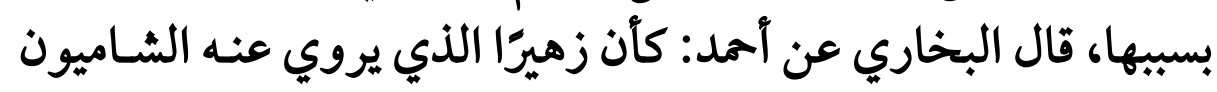
آخر،مات سنة اثنتين وستين ومائة .(1).

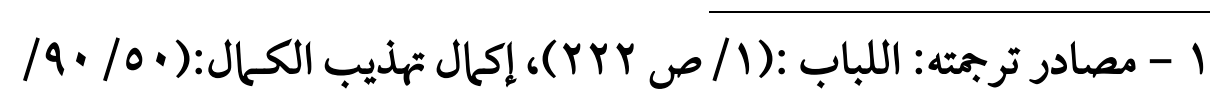

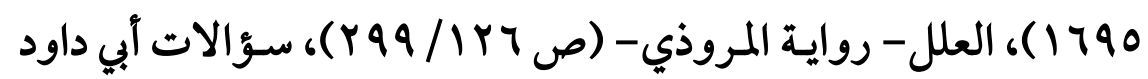




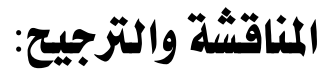

للوقوف على دلالة عبارة العجلي "جائز الحـديث)" في زهـير بـن

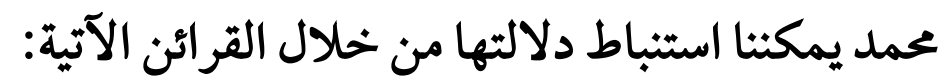

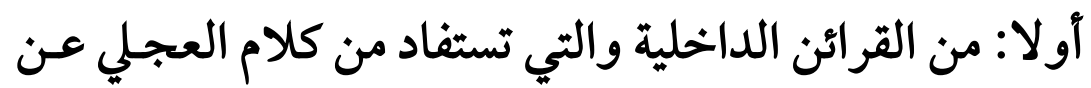

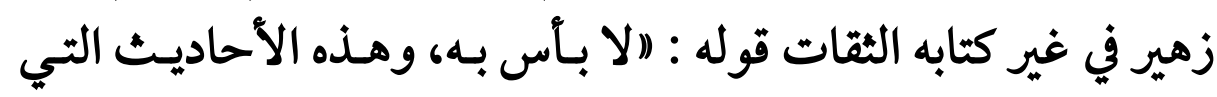

يرويها عنه أهل الشام ليست تعجبني")، فظاهر هذه العبارة تفيد القصور

عن مرتبة الثقة إلى الصدوق مع رد رواياته عن أهل الثام لئام خحاصة.

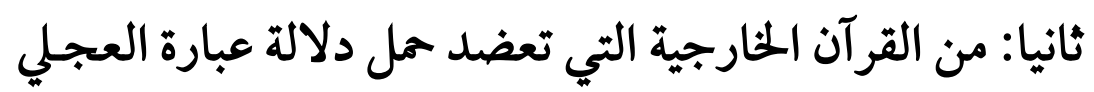

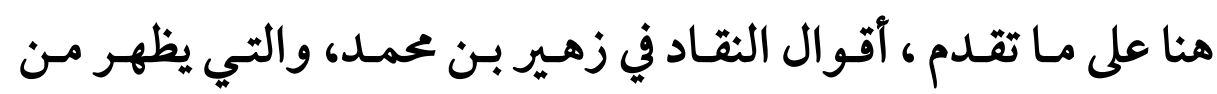

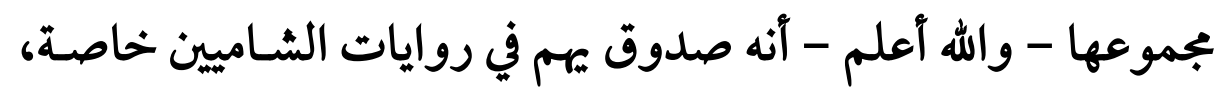
ومن أطلق فيه الضعف وسوء الحفظ، فبسبب ما وقع في حديثه بالشام

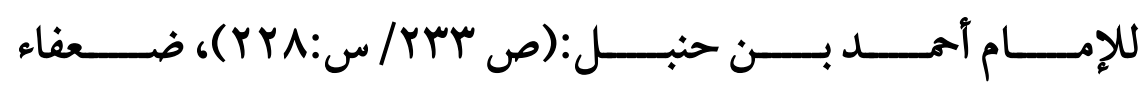

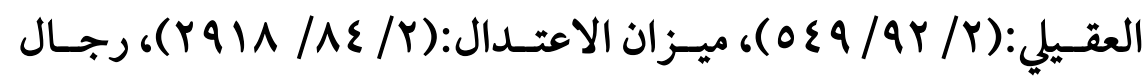

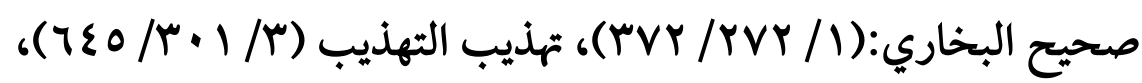

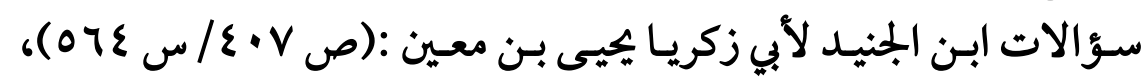

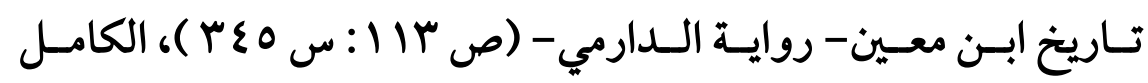

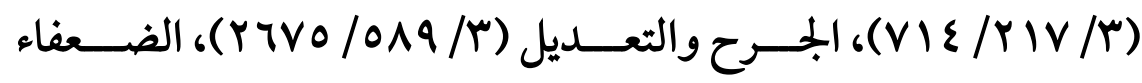

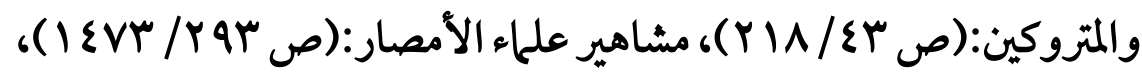

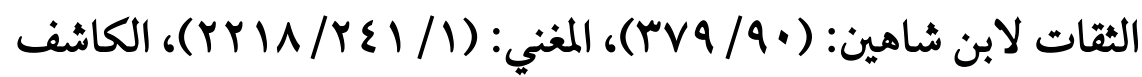

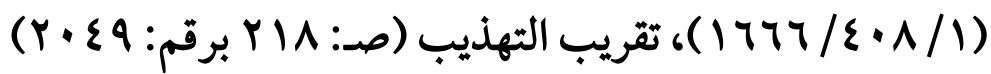




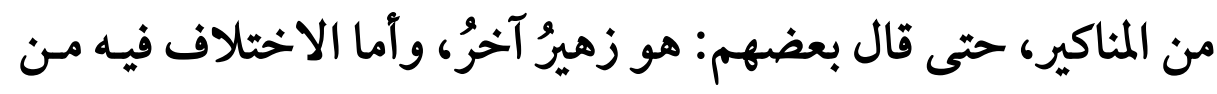

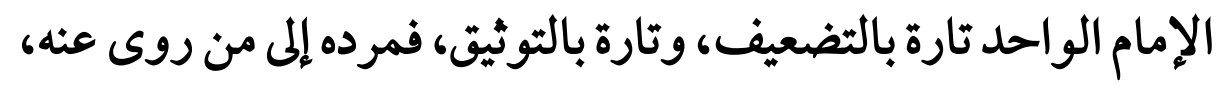

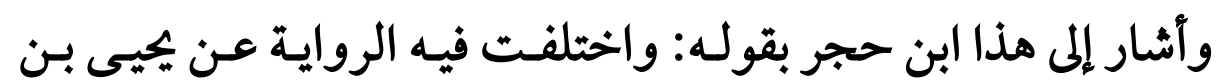

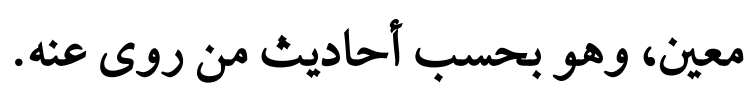

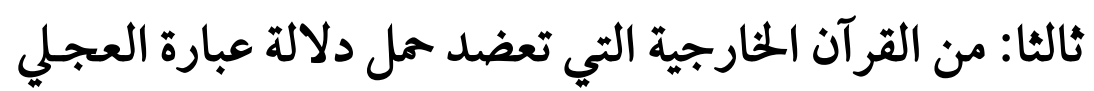

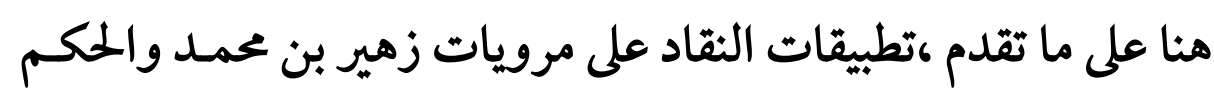

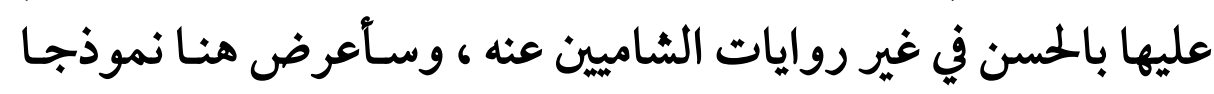

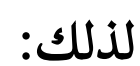

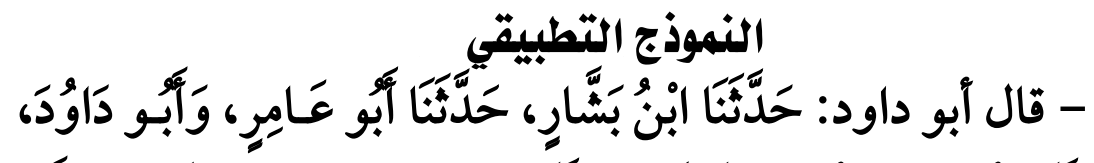

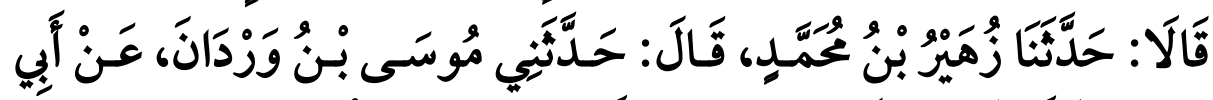

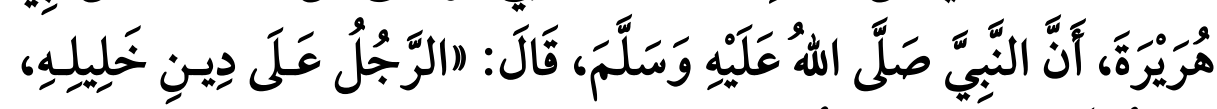

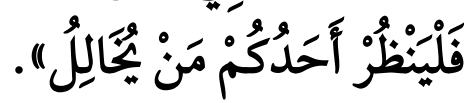

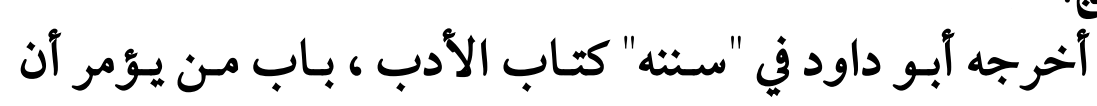

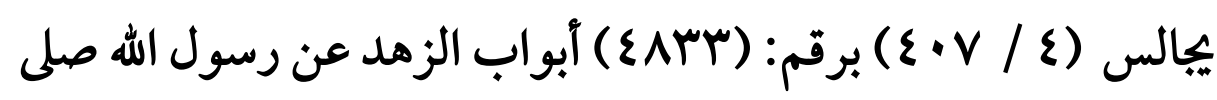

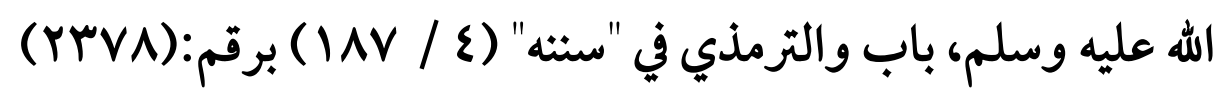

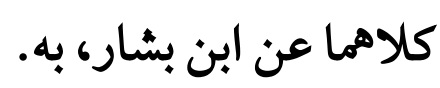
وقال الترمذي: : (هذا حديث حسن غريب). 


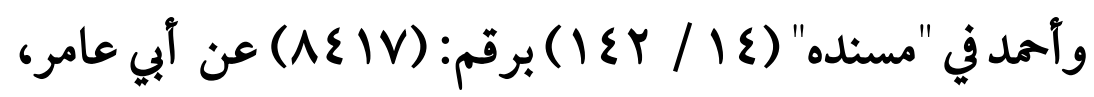
حدثنا زهير، به.

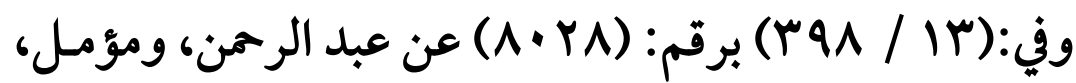
قالا: حدثنا زهير بن محمد، به.

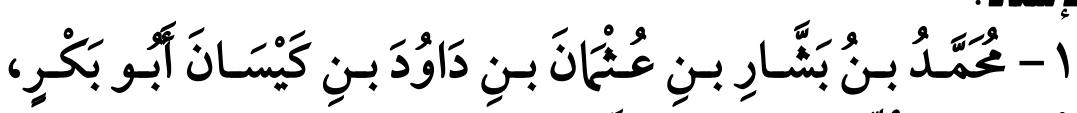

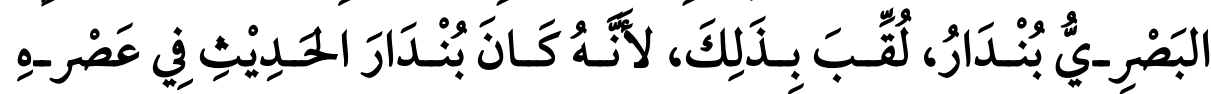

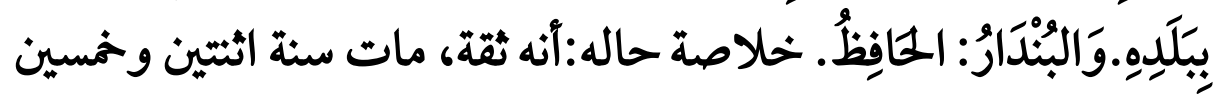

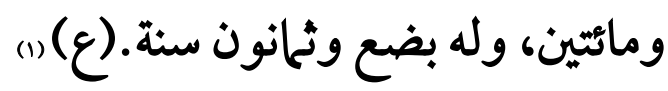

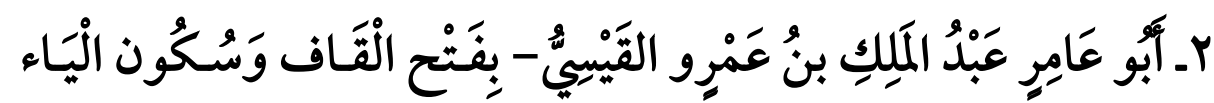

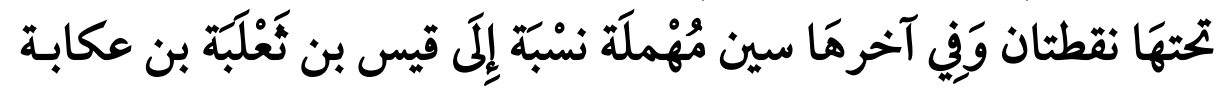

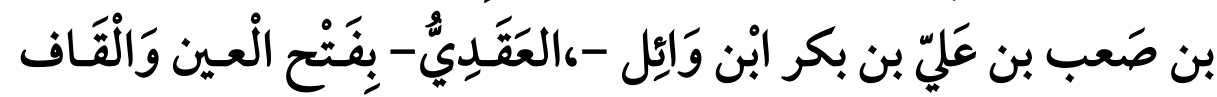

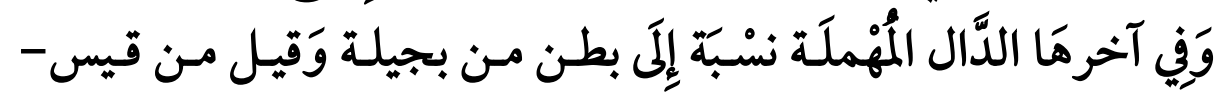

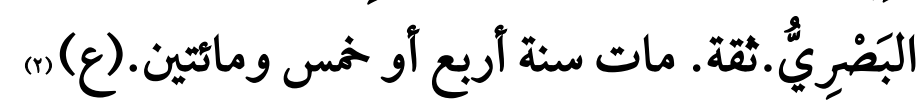

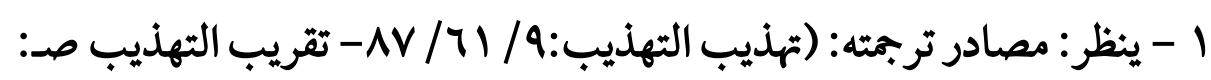

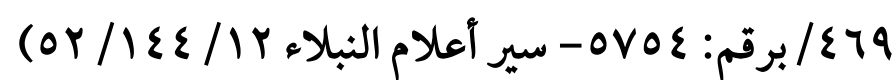

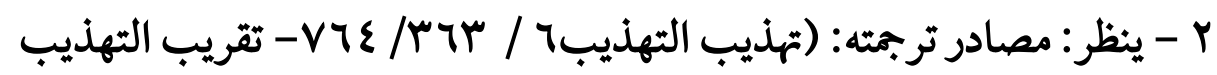

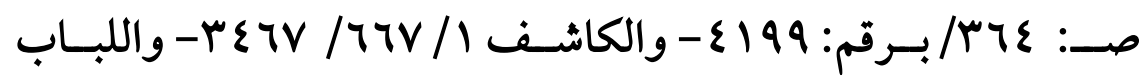

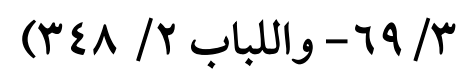




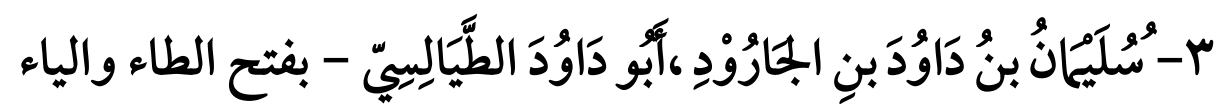
المثناة من تحتها وسكون الألف وكسر اللام ويعدها سين مهملة نسبة إلى دالى

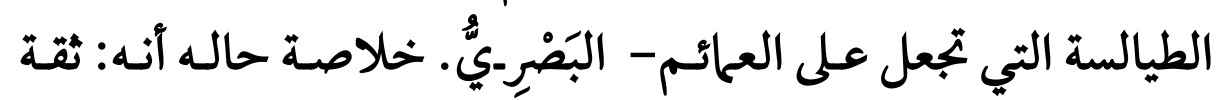

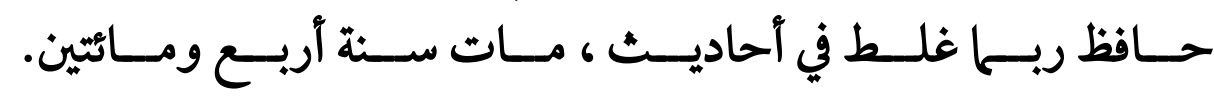
(1)( ) (1)

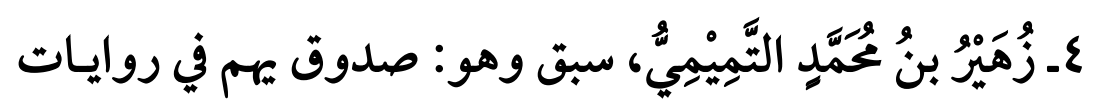
الشاميين خاصة.

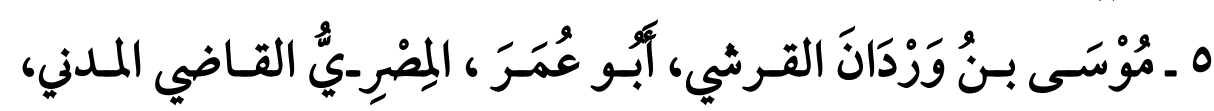

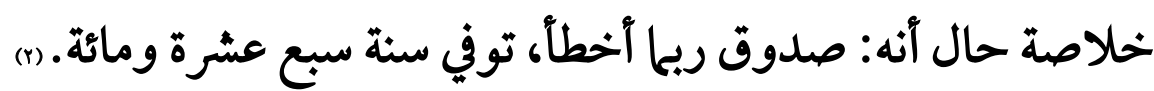

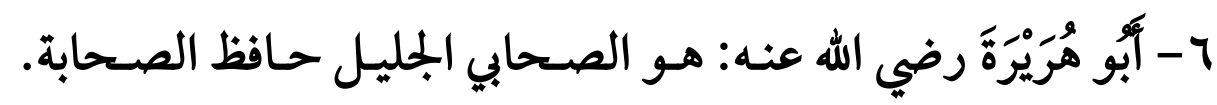

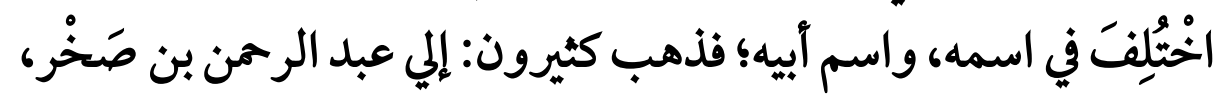

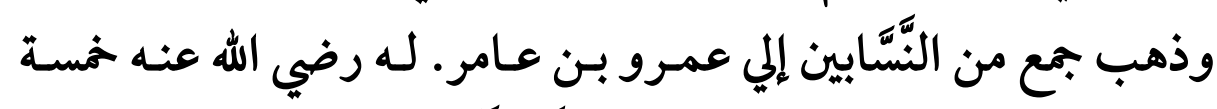

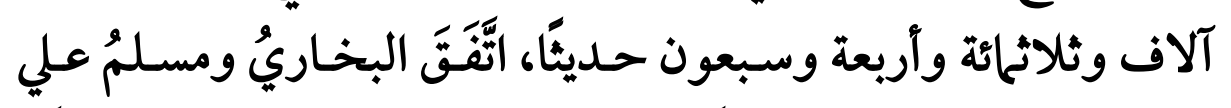
ثلانثائة وخمسة وعشرين حديثًا، وانفرد البخاري بتسعة وسبعين حديثانة

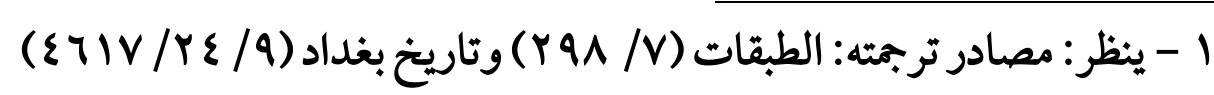

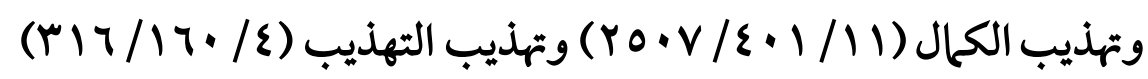

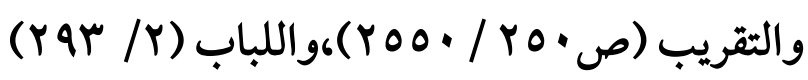

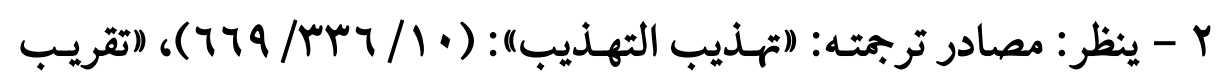

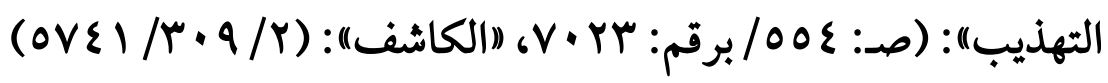


ومسلم بثلاثة وتسعين حديثًا، مات سنة سـبع وقيل : سـنة ثـان وقيل

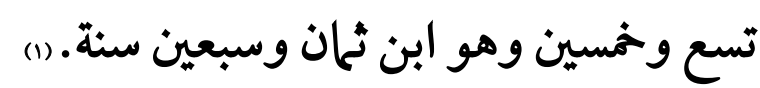

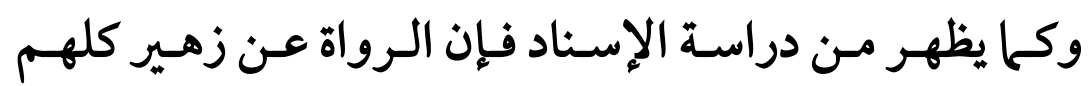

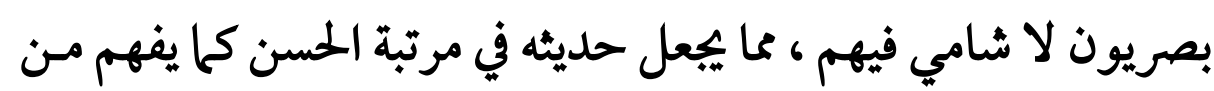
كلام العجلي، وكما طبق الإمام الترمذي فحكم علئم عليه بالحسن.

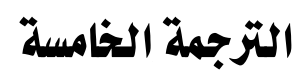

سعيد بن سناز كوفي جائز الحديث. (r).

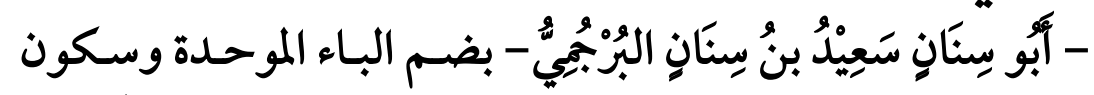

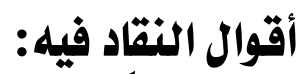

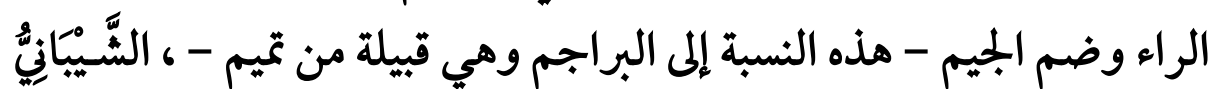

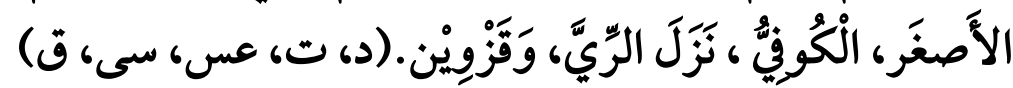

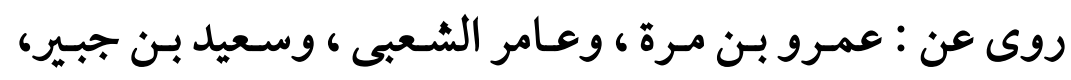

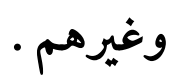
روى عنه : إسحاق بن سليان ،وبكر بـن بكار، وحكام بـن

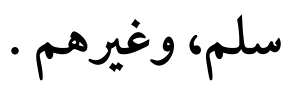

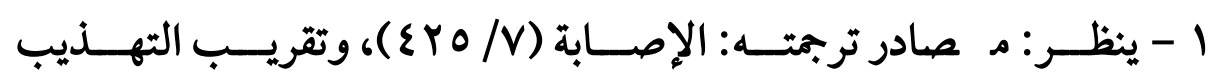

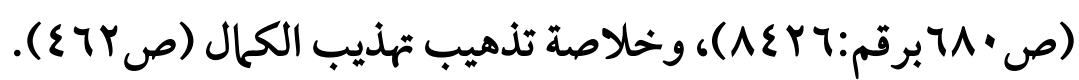

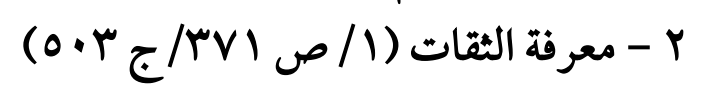


قال أبـو طالب عـن أمـد: كـان رجـلا صـالحا ولم يكن يقيم

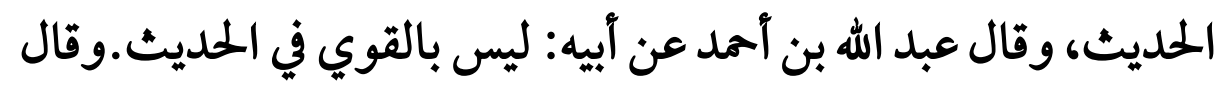

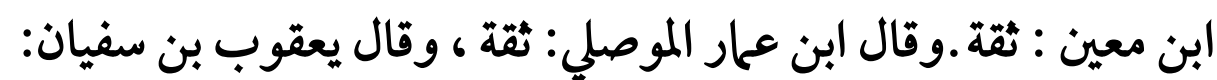

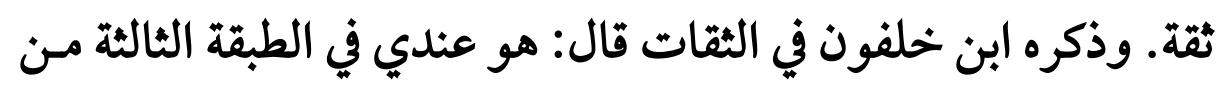

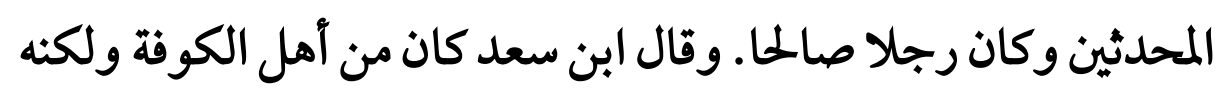
سكن الري وكان يحج كل سنة وكان سيء الخلق .وقال سفيان بن عيينة:

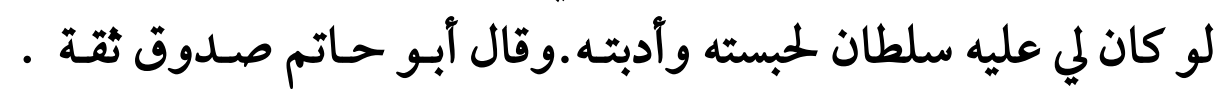
وذكره ابن حبان في الثقات وقال: كان عابدا فاضلا ، وقال وقال في المشاهير:

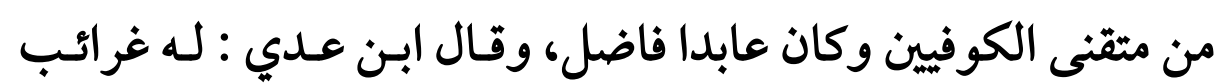

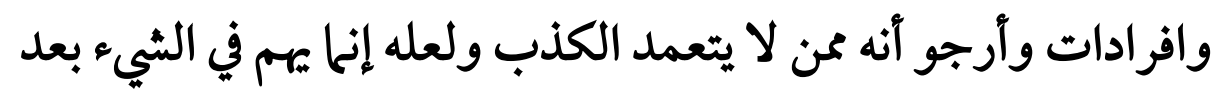

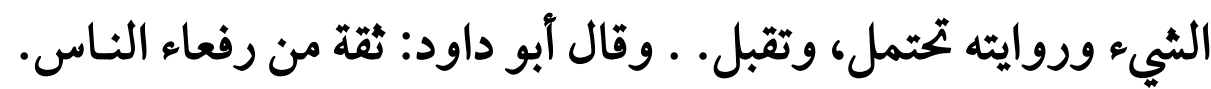

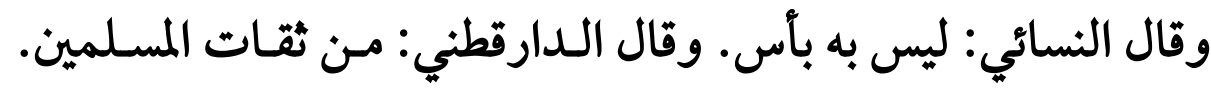

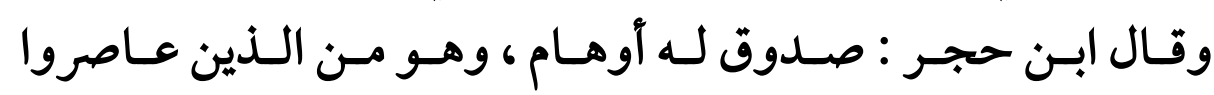

صغار التابعين (1)

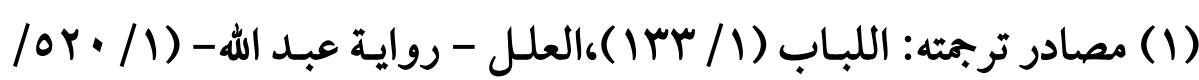

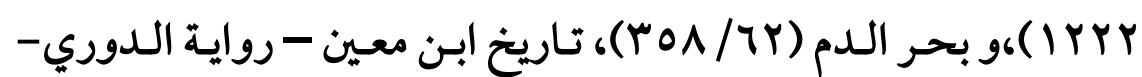

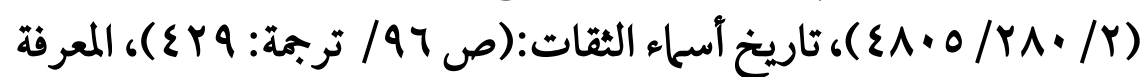

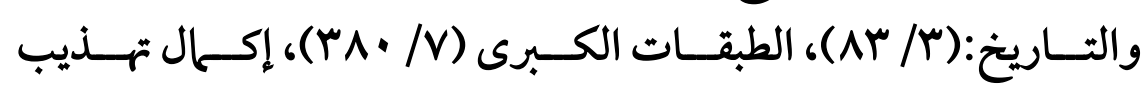

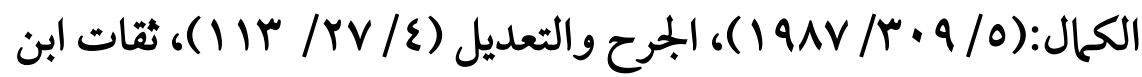




\section{المناقشة والترجيج}

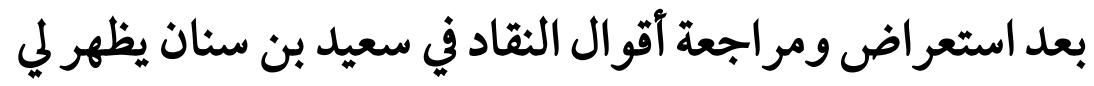

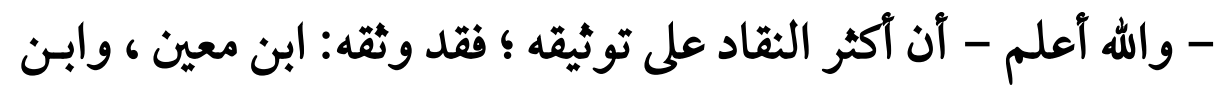
عمار، ويعقوب، توأبو حاتم ، وابن حبـان،وأبو داود، والدارقطني،فئيا

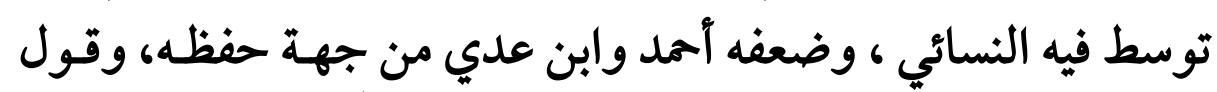

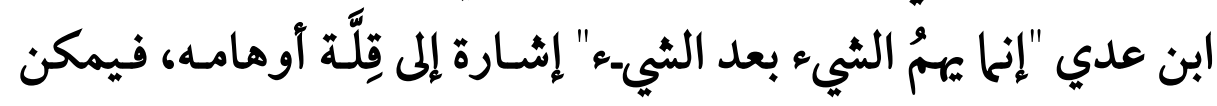
إعتبار ما سبق نقله عن جماهير الإئمة قرينة خحارجية لتوجيه دلالة قول إلها

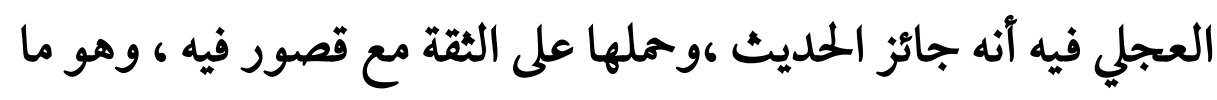

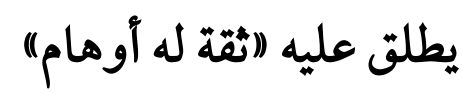

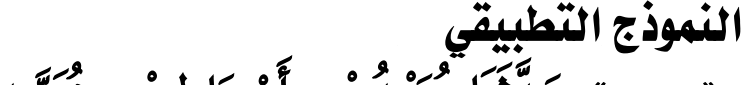

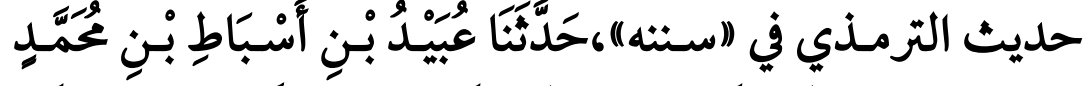

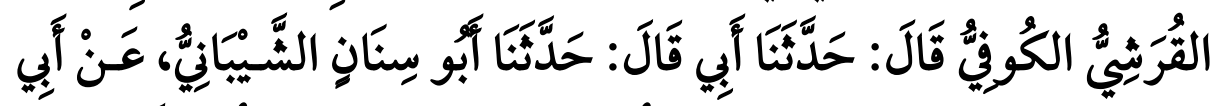

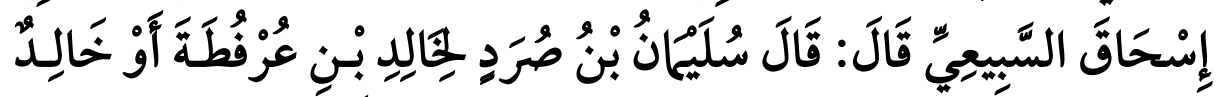

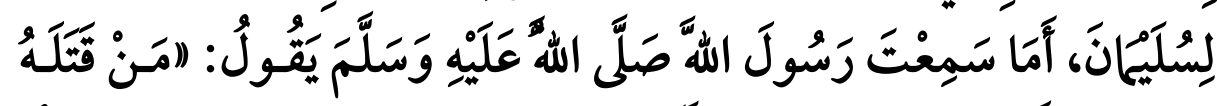

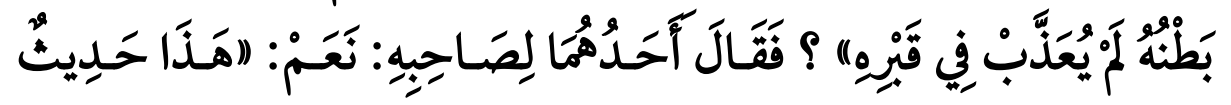

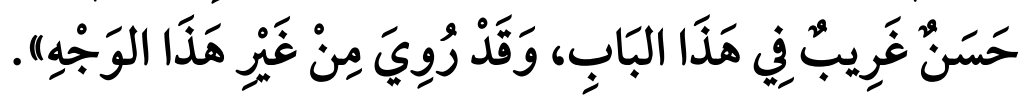

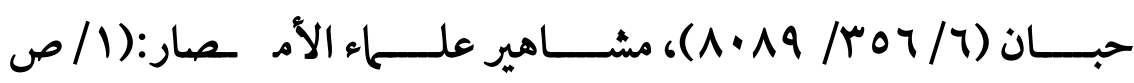

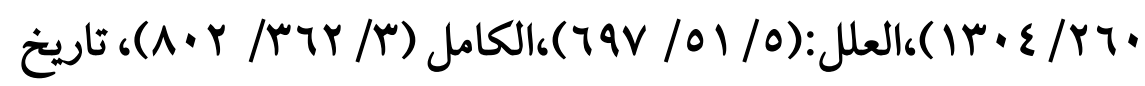

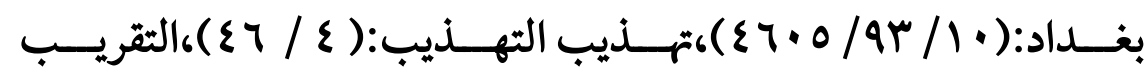

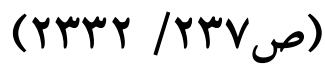


أخرجه الترمذي في "سننه" أبواب الجنائز عـن رسول الله صلى

الله عليه وسلم ، باب ما جاء في الشـهداء مـن هـم (Y / 70 بر) بـرقم:

أخرجه ابن حبـان في "صحيحه" كتـاب الجنائز ومـا يتعلق بها

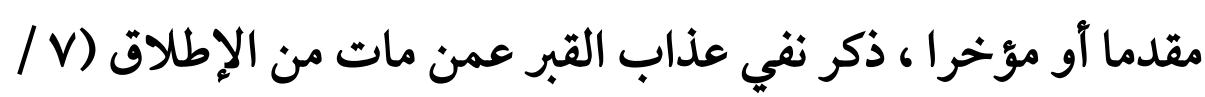

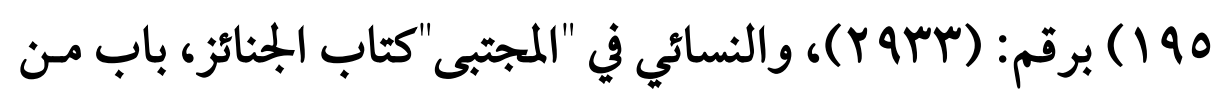

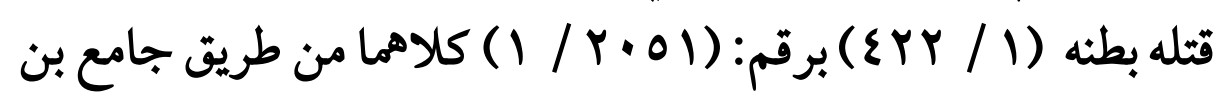

شداد، به، بنحوه مطولا. دراسة الإسناد:

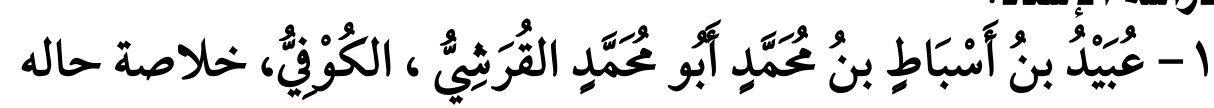
أنه: صدوق من الحادية عشرة مات سنة خحسين وماتتين. (1)

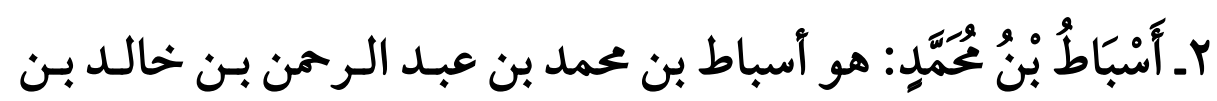

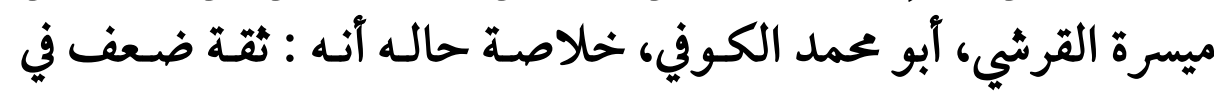

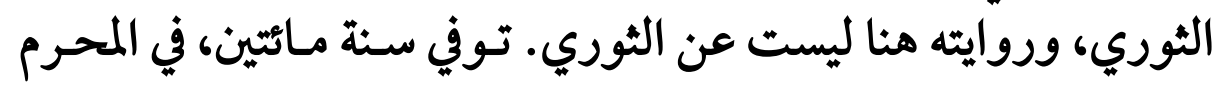

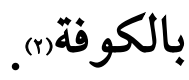

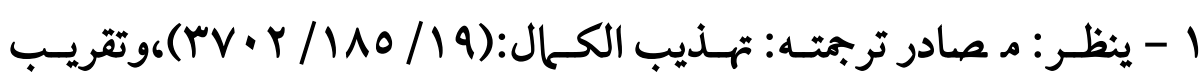

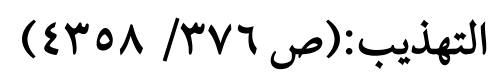

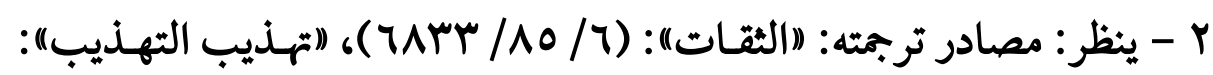

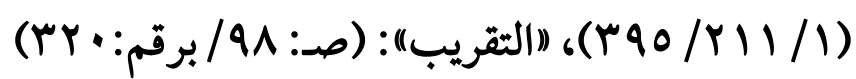




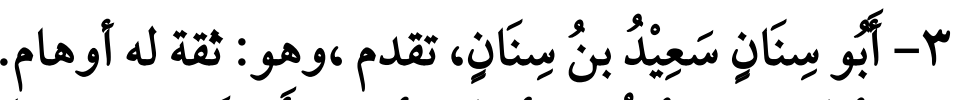

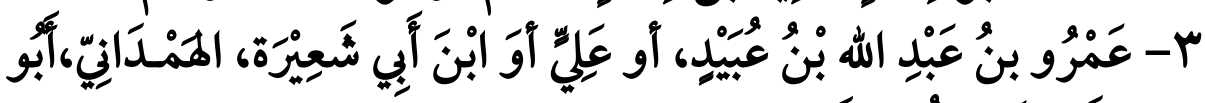

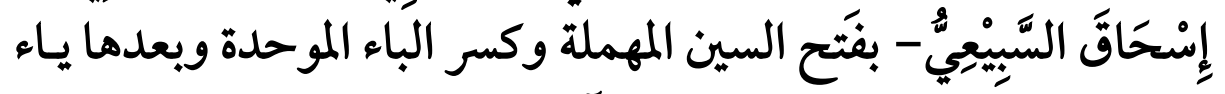

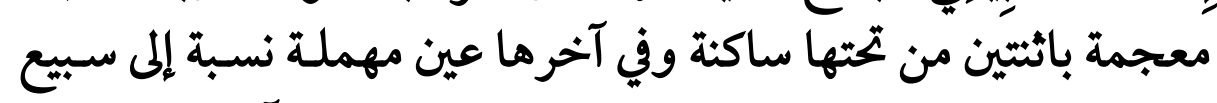

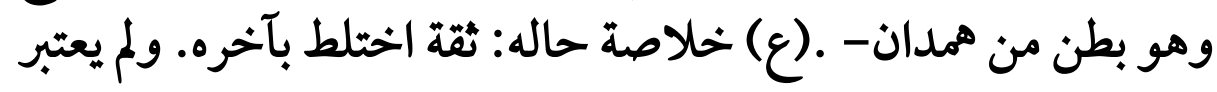

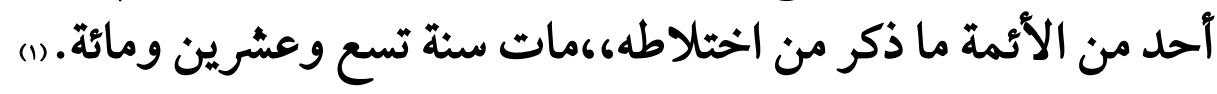

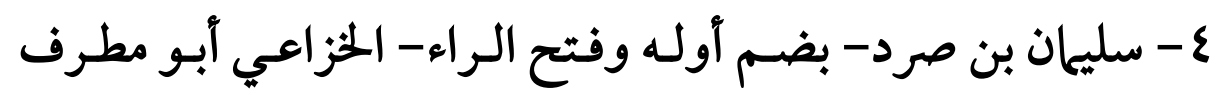

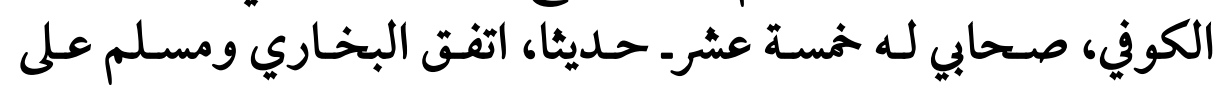

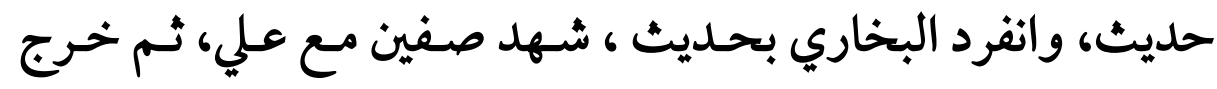

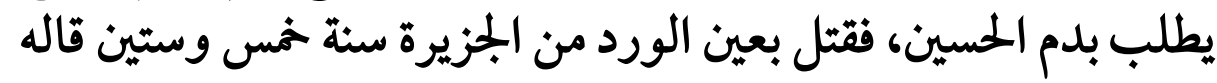
ابن سعد، وكان حبرا صالحا شريفا في قومه. ((r).

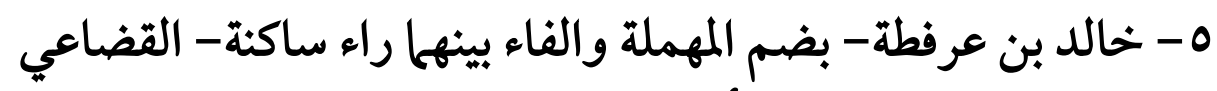

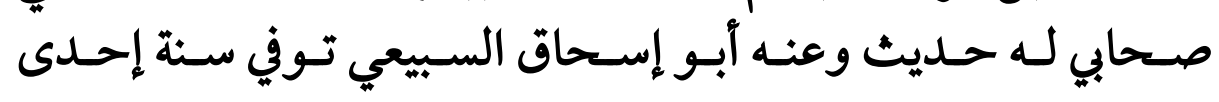

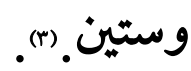

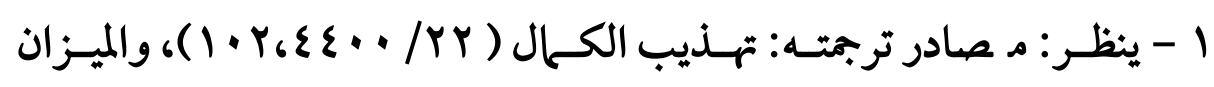

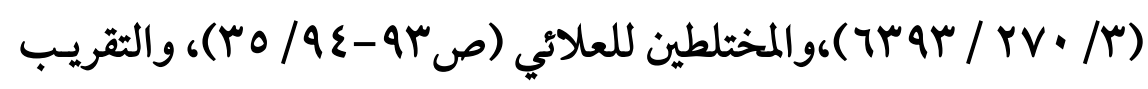

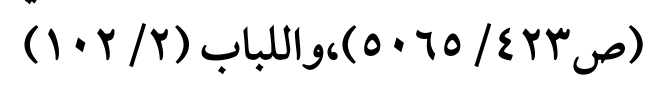

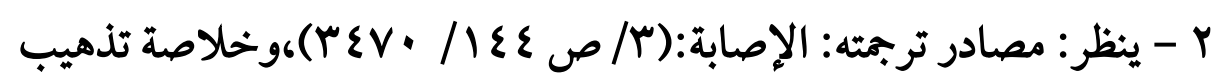

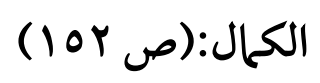

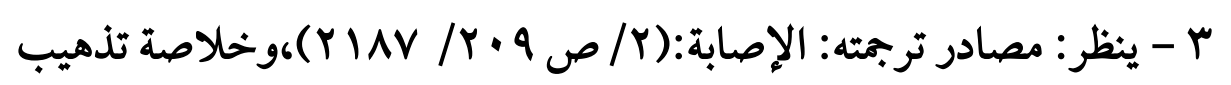

$$
\text { الكمال:(ص r (1) }
$$


الحكم على إسناد الترمذي:

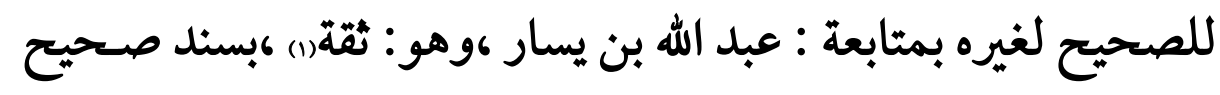
كما سبق تخريجه عند النسائي في المجتبى. التزجمة السادسة

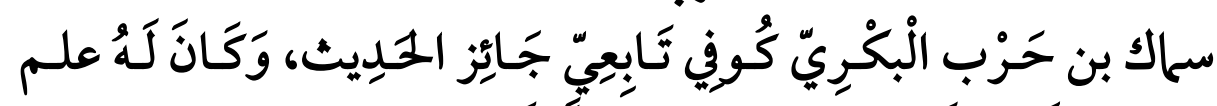

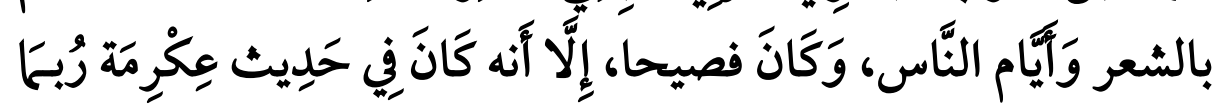

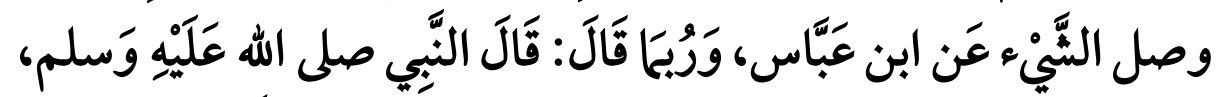

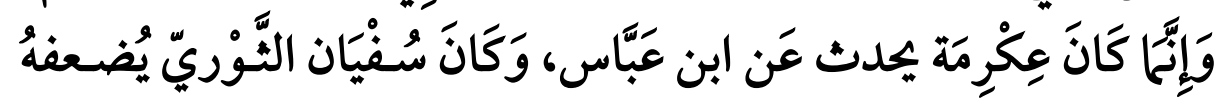

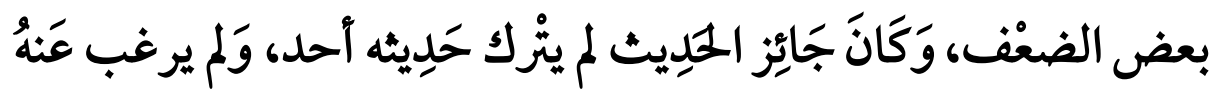
أحد..(1).

أقوال النقاد فيه:

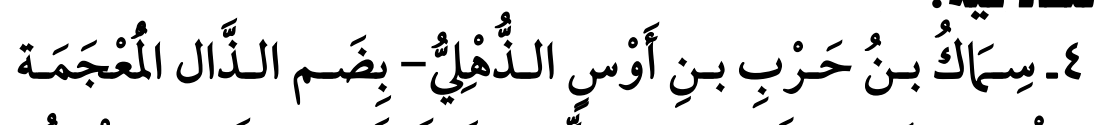

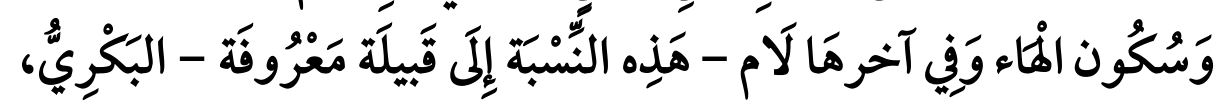
أبو المغيرة الكوفي.

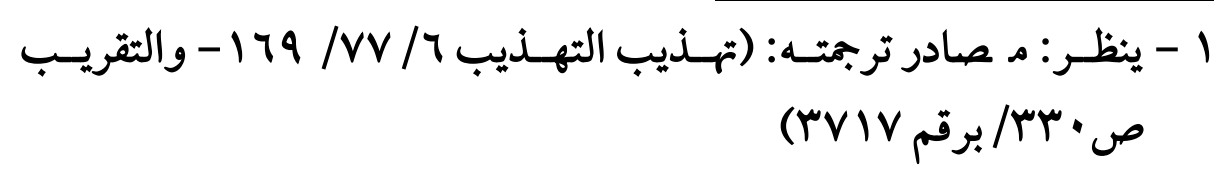

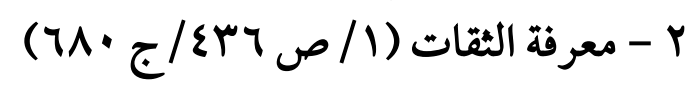


روى عن أنس بن مالك، وإبراهيم النخعي، وحَنَشِ بنِ المُعتنَمِرِ

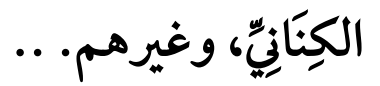

وروى عنه الأعمـش، وزائـدة بـن قدامـة، وشـبة، والثهوري، وعي،

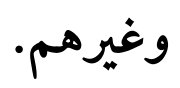

قال ابن شاهين: ثقة.قال حماد بن سلمة عنه: أدركت ثُانين مـن

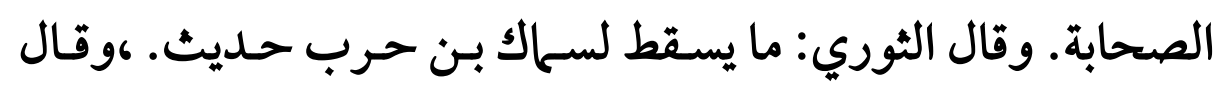
أحمد: سهاك أصح حديث من عبد الملك بن عمير.

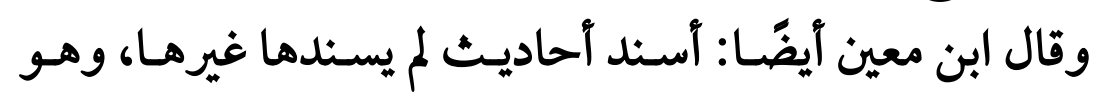

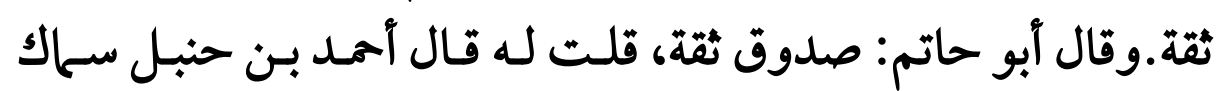

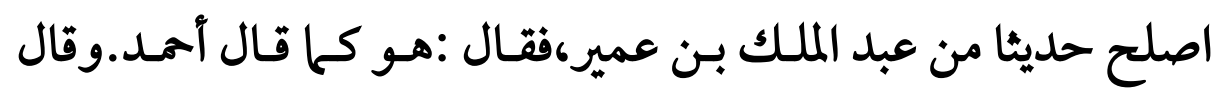

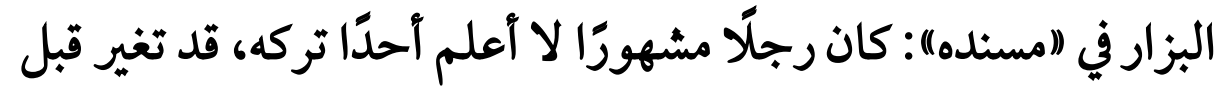
موته. وقال ابن عدي: ولسماك حديث كثير مستقيم إن شاء الله وهو من

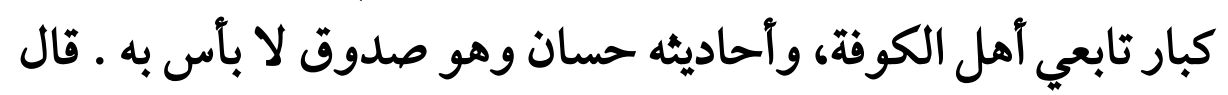

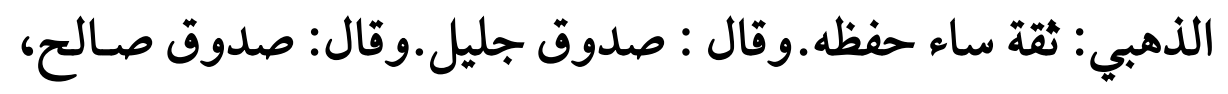
من أوعية العلم، مشهور.

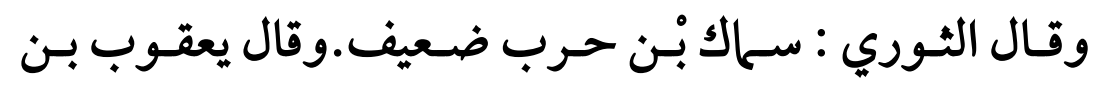

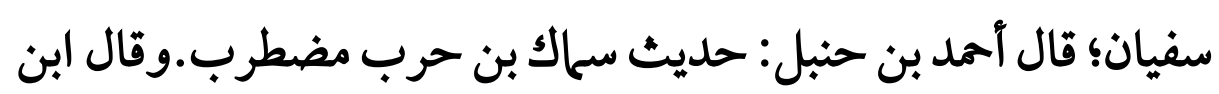

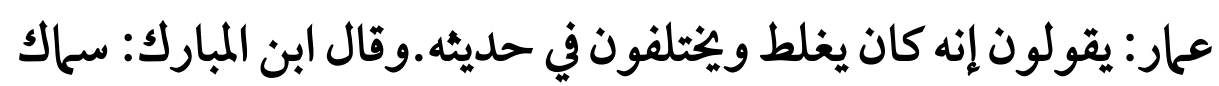
ضعيف في الحديث.وقال النسائي: ليس بالقوي وكان يقبل التلهينين. 


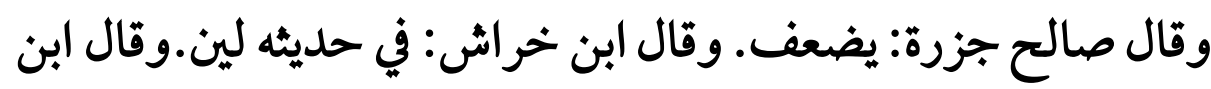

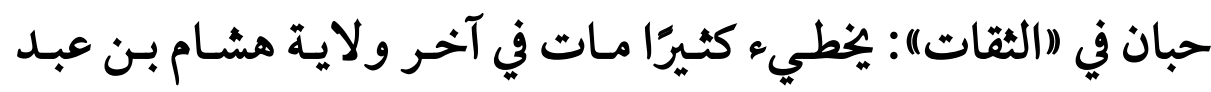

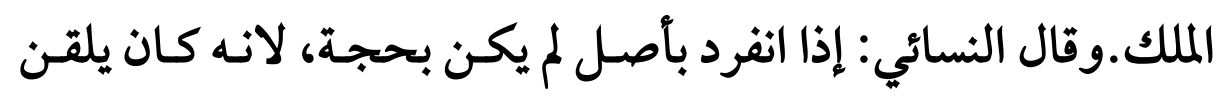
فيتلقن..وقال الدارقطنى: سيء الحفظ.

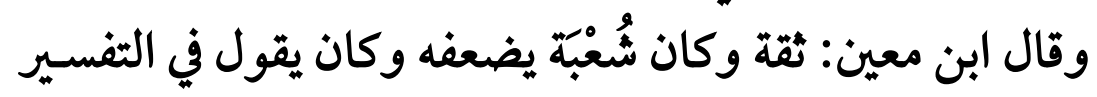

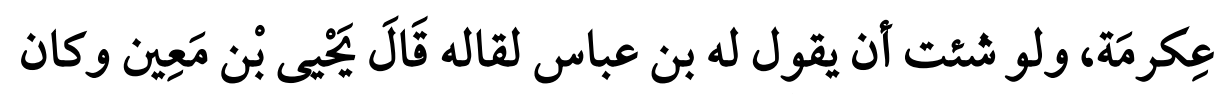

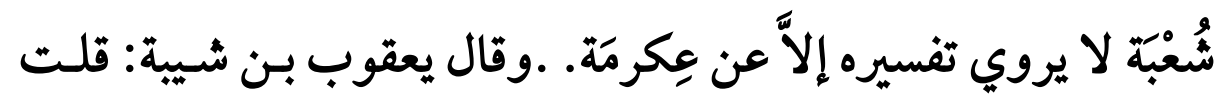

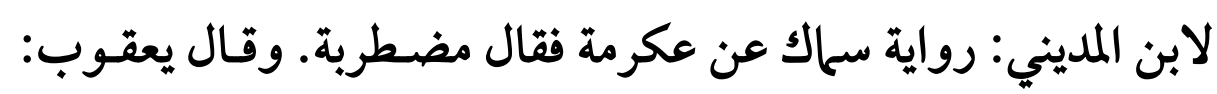

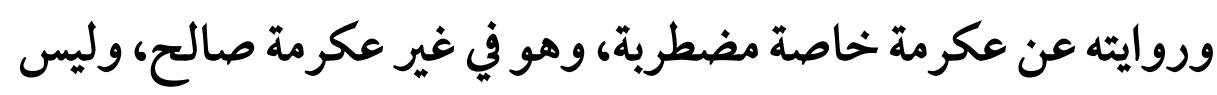

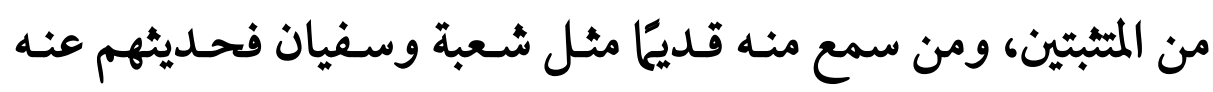

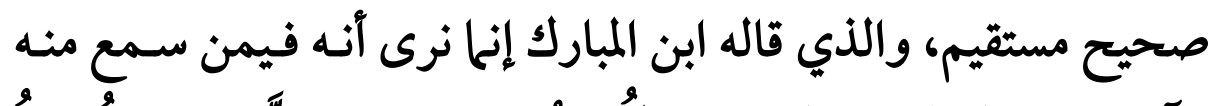

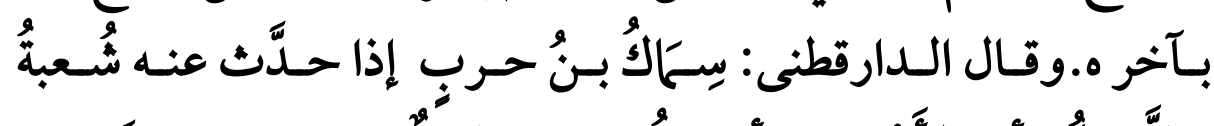

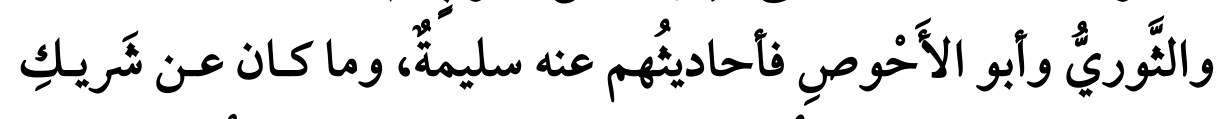

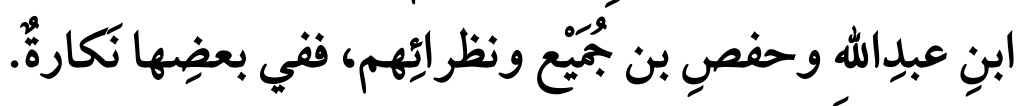

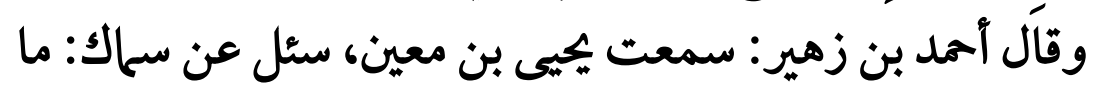

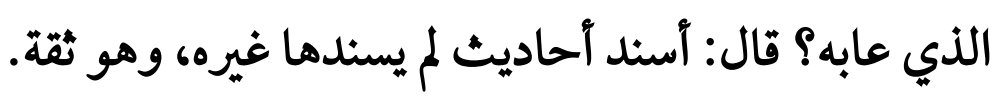

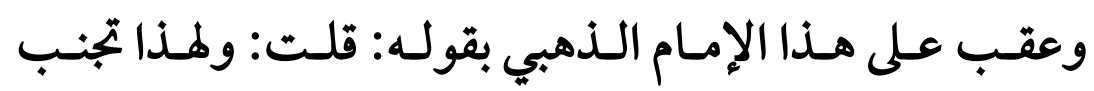

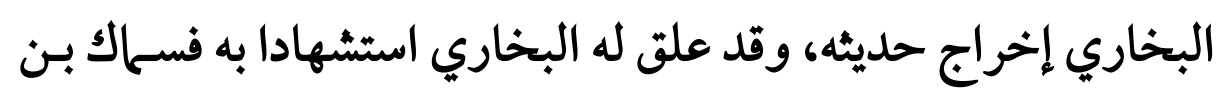

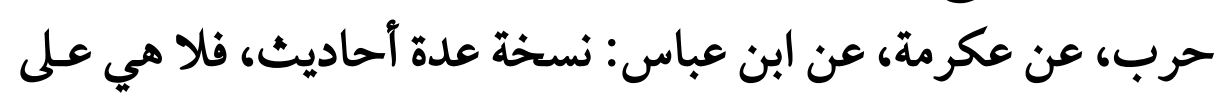


شرط مسـلم؛ لإعراضـه عن عكرمة، ولا هي على شرط البخـاري؛ لإعراضه عن سماك، ولا ينبغي أن تعد صحيحة؛ لأن سماكا إنها تكلم فيه من أجلها.

وقال ابن حجر: صدوق، وروايته عن عكرمة خاصة مضطربة، وقدان

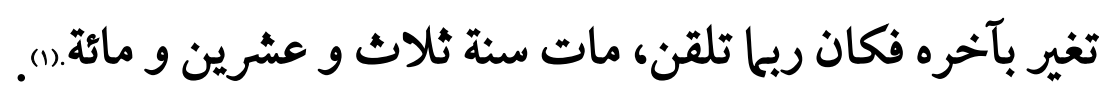

\section{المناقشة والترجيح}

بعد استعراض ومراجعة أقوال النقاد في سعيد بن سنان يظهر اختلاف النقاد في حاله ما بين من يضعف بإطلاق، ومن يوثق باطلاق،

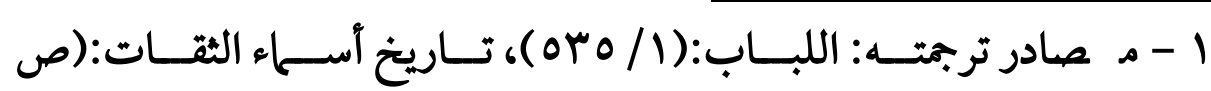

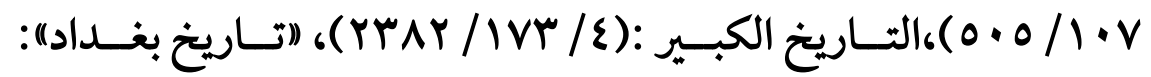

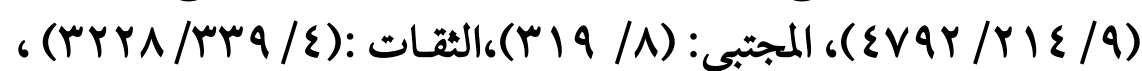

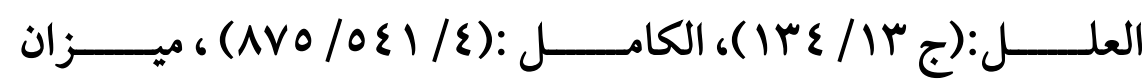

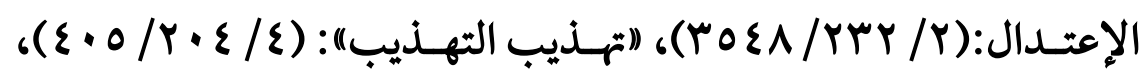

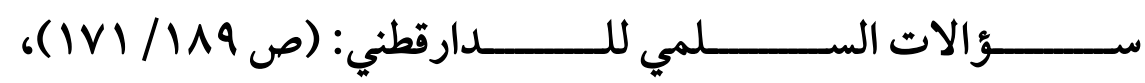

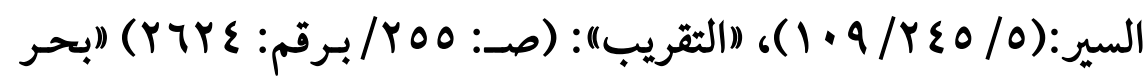

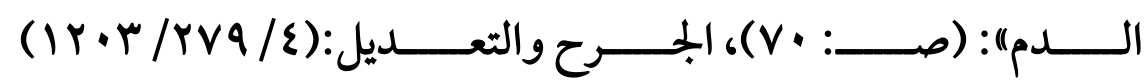

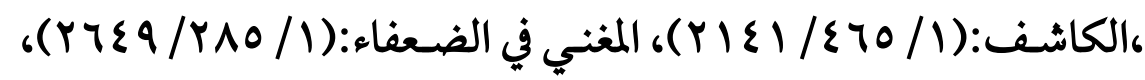

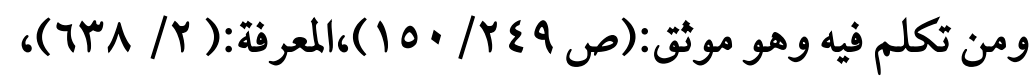


ومن يفصل القول في حاله، فيحمل حـال التضعيف على غير حال

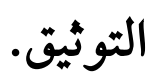

ويمكن الوقوف على دلالة عبارة (جائز الحديث) عند العجلي هنا ومملها على صدوق يضعف في عكرمة خاصة ، من خلالال القرائن

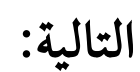
1- من القرائن الداخلية: مـا ورد في كـلام الإمام العجلي مـن

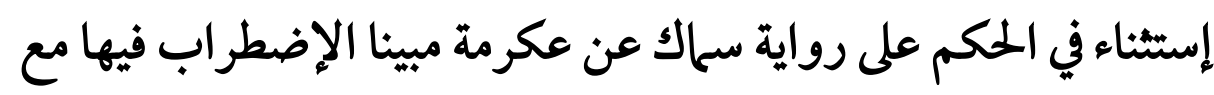

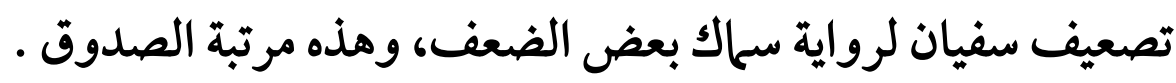

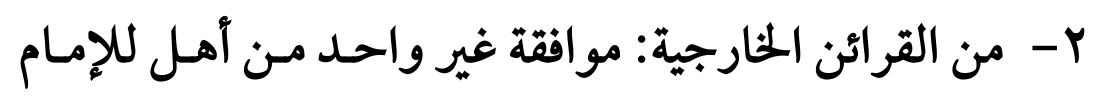
العجلي فيا ذهب إليه من تفصيل، حتى قال الذهبي: فسماك بن بن حرب،

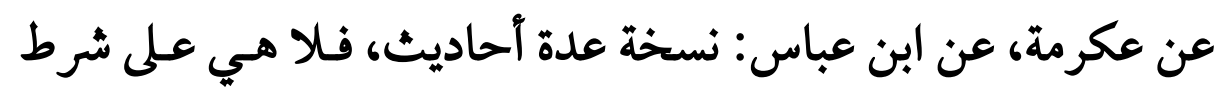

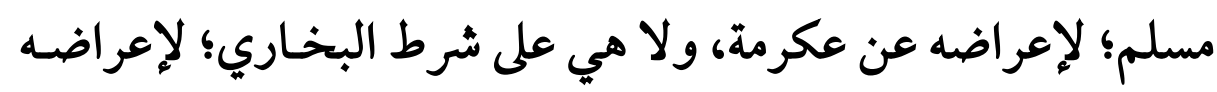

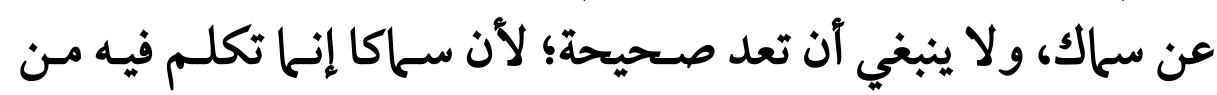

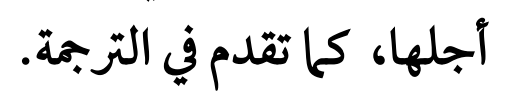
ويلتقي هذا مع قول الحافظ ابن حجر فيه: صدوق، وروايته عن

عكرمة خاصة مضطربة.

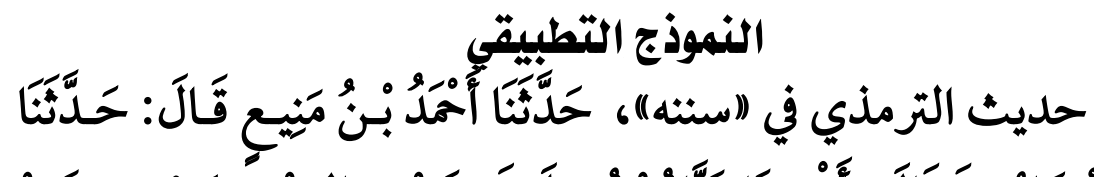

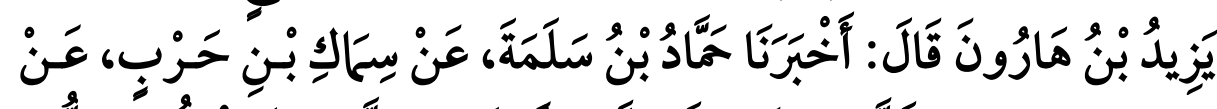

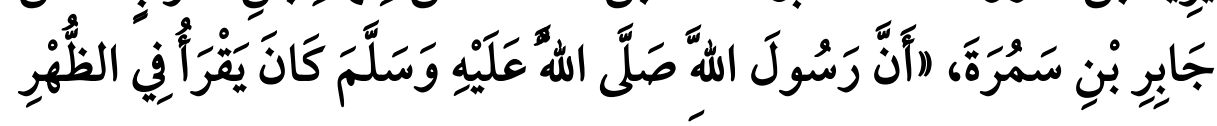




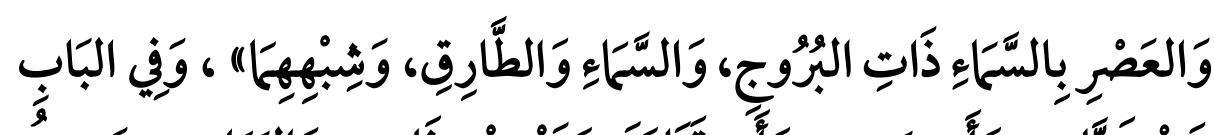

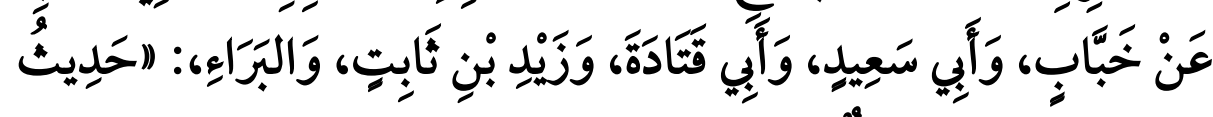

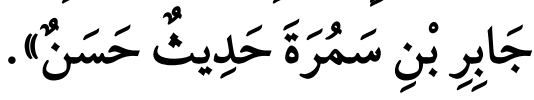

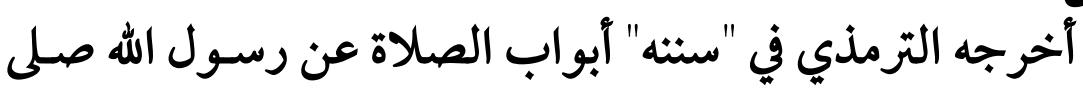

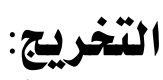

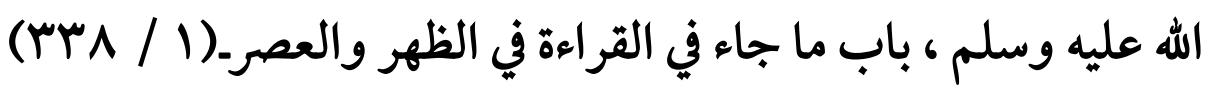
برقم: (r·v)

وأخرجه أبو داود في "سننه" كتاب الصلاة ، باب قدر القراءة في

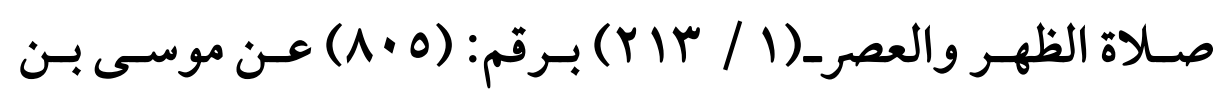

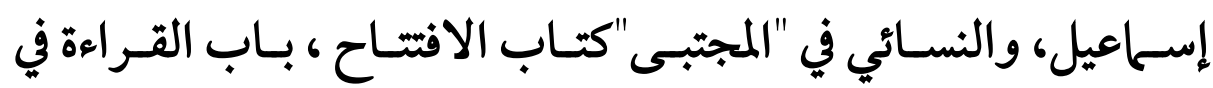

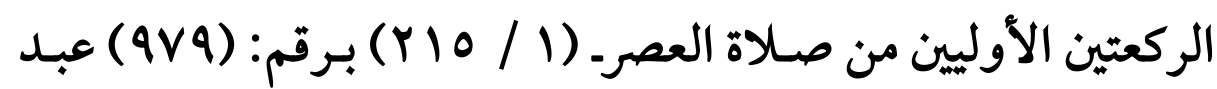
الرممن بن مهدي ، كلامما:( موسى، وعبد الرممن) عن حماد،به.

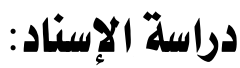

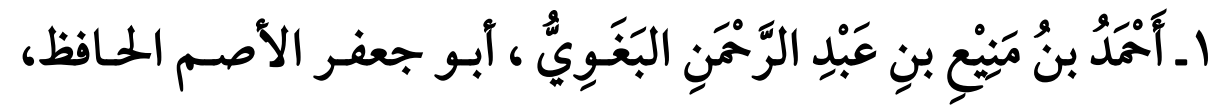

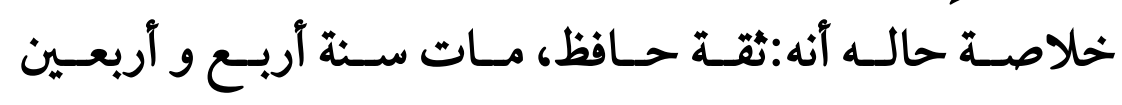
ومائتين(ع). (1)

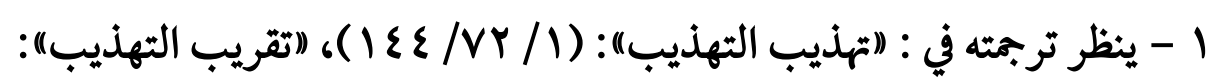

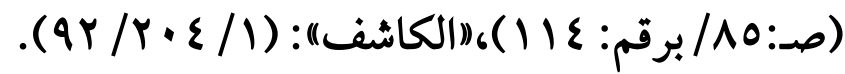




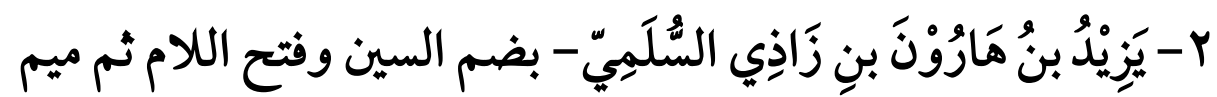
نسبة إلى سليم بن منصور بنُ عكرمة بن خصفة بن قيس عيلان

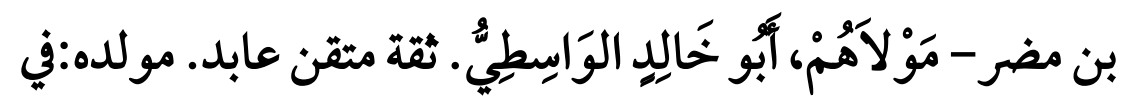
سـنة ثُهان عشرـة ومائة،وومات سـنة سـت ومـائتين وقـد قـارب

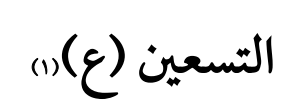

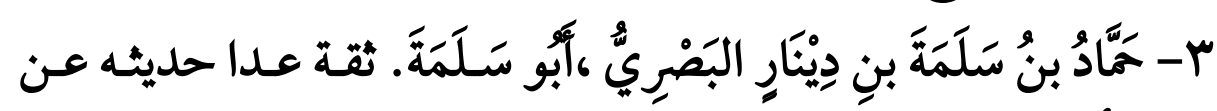

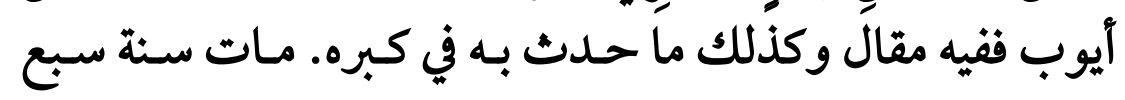

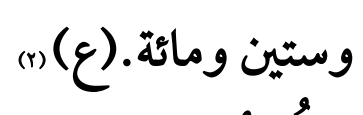

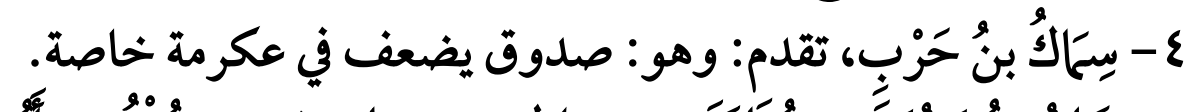

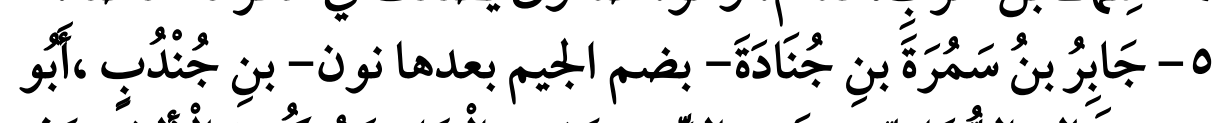

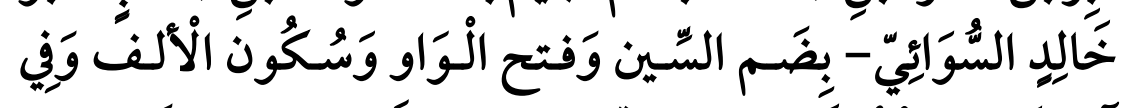

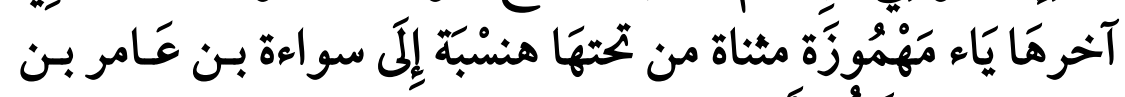

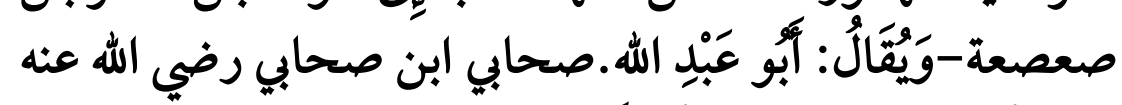

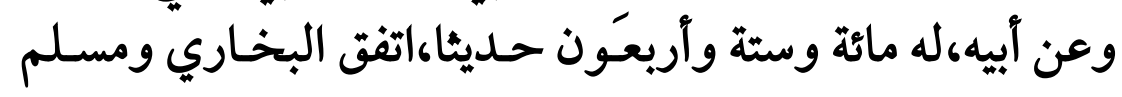

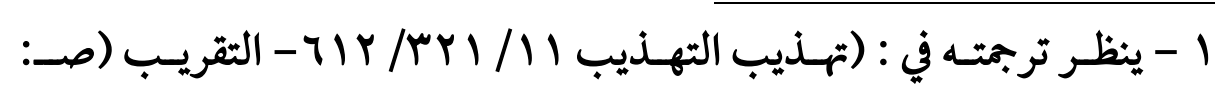

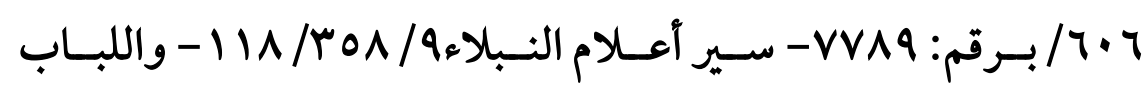

$$
\text { (I } Y \wedge / r
$$

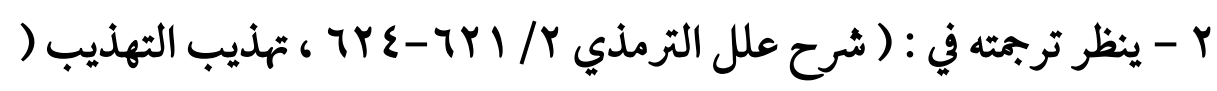

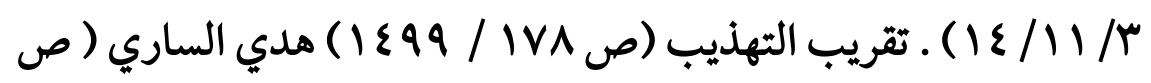


(VI)

على حديثين،وانفرد مسلم بثلاثة وعشرين،نزل الكوفة ومات بها

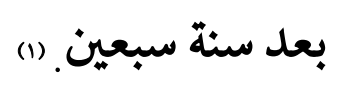

الحكم على الإسناد: حسن لاأجل سماك بن حرب، وهو صدوق

في غير روايته عن عكرمة فضعيف.

الترجمة السابعة

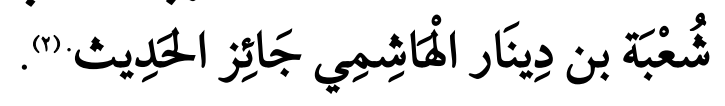

أقوال النقاد فيه:

شُعْبَة بن دِينَار الْهاشِمِي مولاهم، أبو عبد الله، ويقال: أبو يهيى

مدني.) مد: (د)

روى عن: مولاه عَبد اللهَّْن عباس.

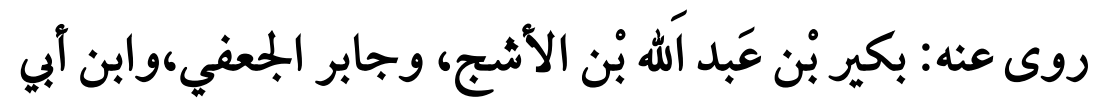

قال أحمد: ما آرى به بأس قال مالك لم يكن يشبه القراء.وقال أبو

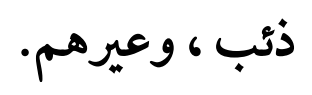
داود: قال سمعت أممد قيل له شعبة مولى ابن عباس فقال قال مالك لمالم مالم

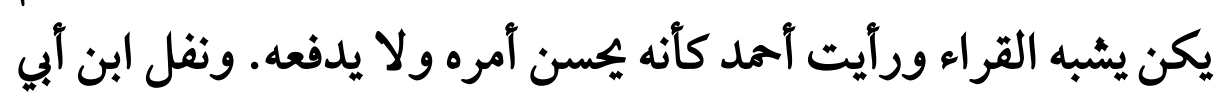

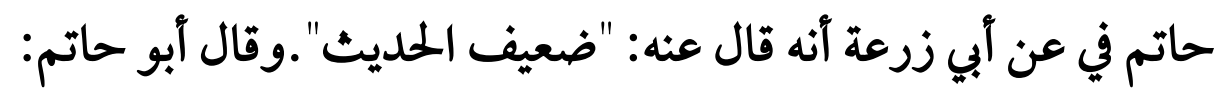

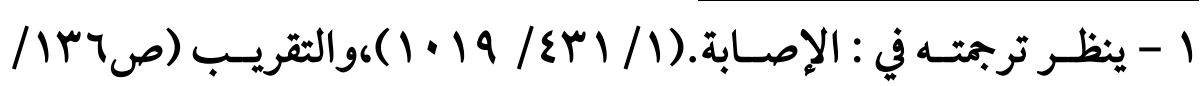

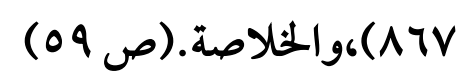

$$
\begin{aligned}
& \text { r - معرفة الثقات (I/ ( }
\end{aligned}
$$


ليس بقوي. وقال ابن حبان: يروي عن بن عباس مالا أصل له كأنه بن عباس آخر.

وقال ابن سعد: قال يحيى بن سعيد القطان: فقلت لمالك بـن

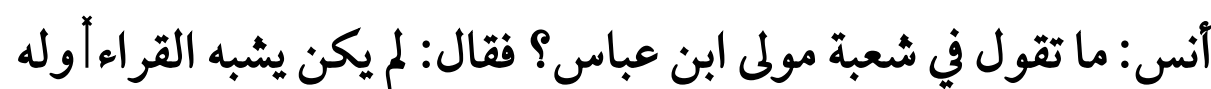

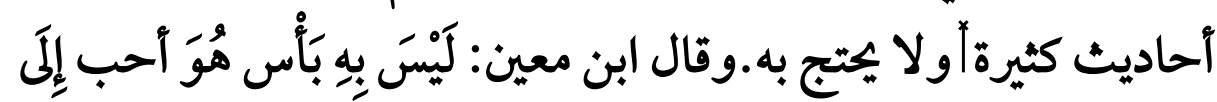

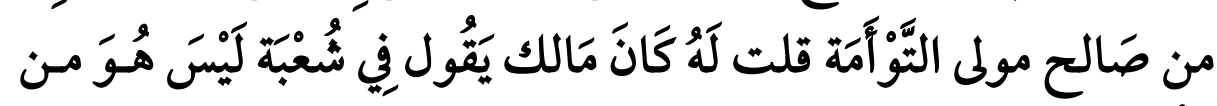
الْقَُّاء.

وقال الجوزجاني: ليس بالقوي في الحديث. وقال ابن أبي خيثمة:

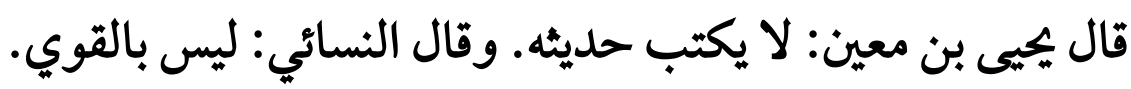

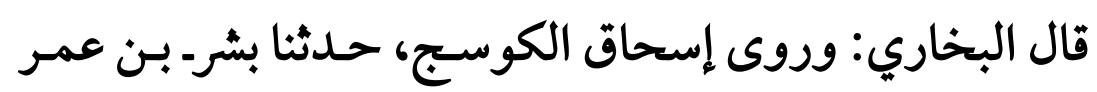

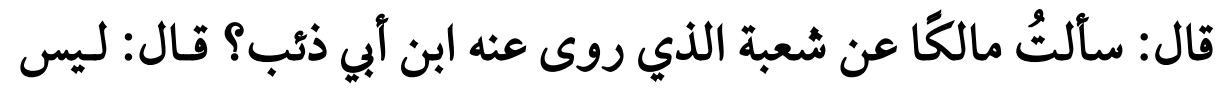
بثقة.وفي رواية ابن عدي عن مالك زاد فيها: فلا تأخذن عنه شَّيًَّا.

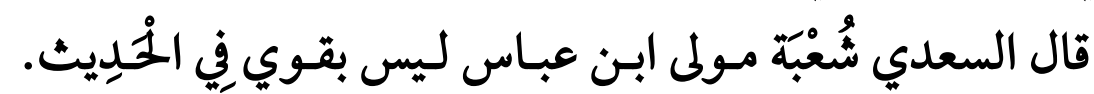

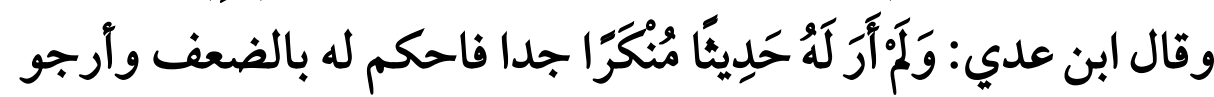

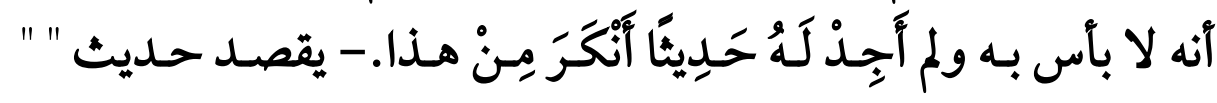

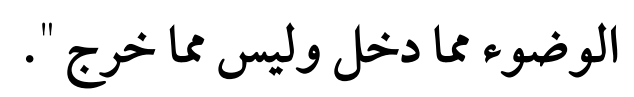

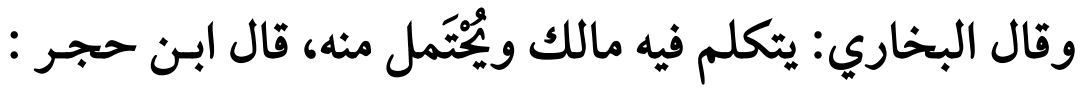

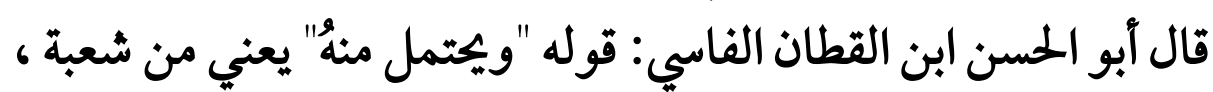

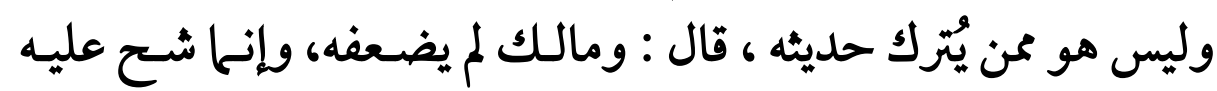


بلفظة ثقة . قلت : هذا الثأويل غير شائع، بـل لفظة (ليس بثقة) في الاصطلاح توجب الضعف الشديد قلت- الباحث- ومما يمكن الاستدلال بـه لما ذهـب إليه ابن الئن

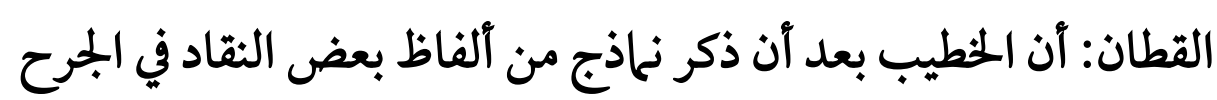

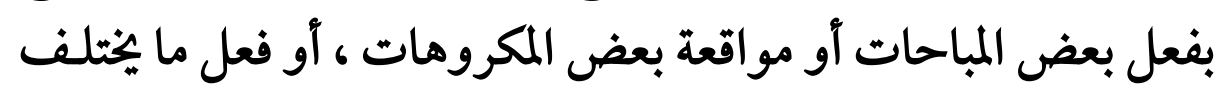

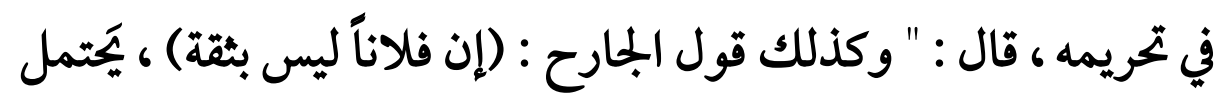
أن يكون لمثل هذا المعنى ، فيجب أن يفسَّر سببه.

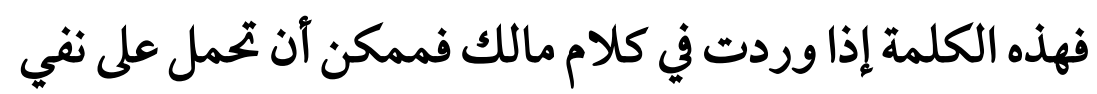

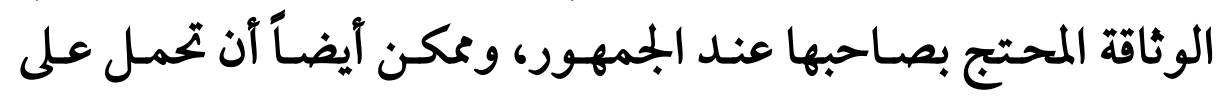
المتروكين عند مالك، ولو كان فيهم من هو ثقة عند جمهور النقدة، وهنا يجب مراعاة القرائن ليستبين المراد.

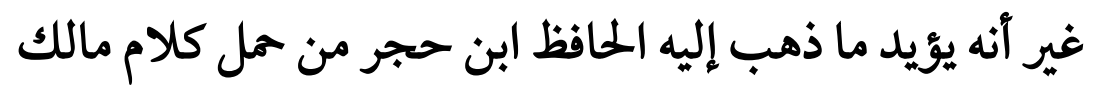

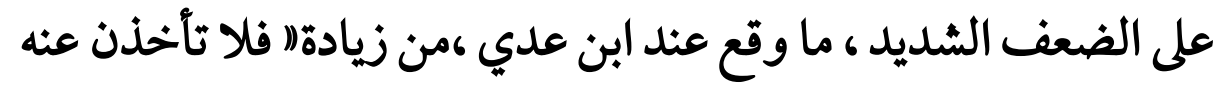

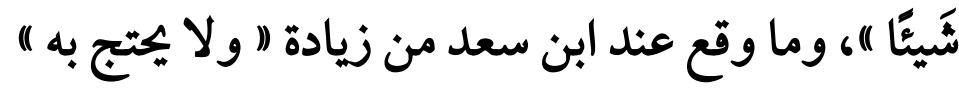

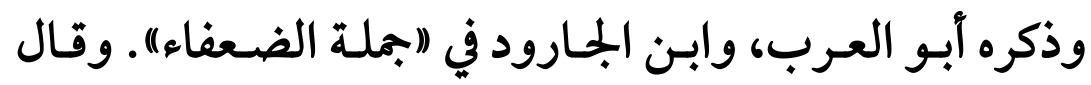

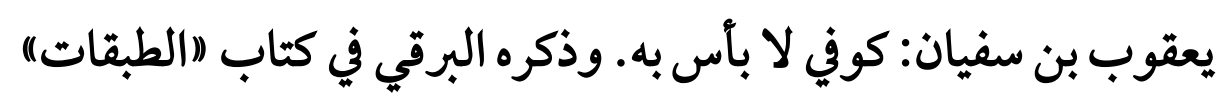

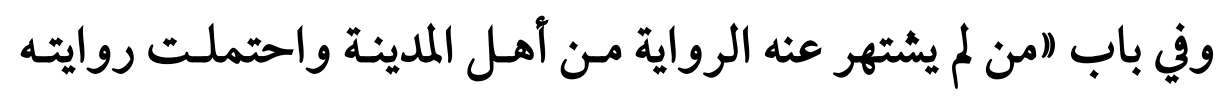

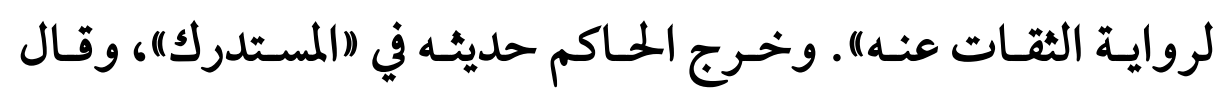

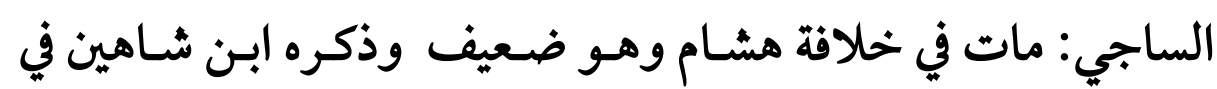


(الثقات)، وقال ابن حجر : صـدوق سيء الحفظظ مـن الرابعة مـات في وسط خحلافة هشام. (1).

\section{المناقشة والترجيح}

بعد استعراض ومراجعة آقوال النقاد في شعبة بـن دينـار يظهر

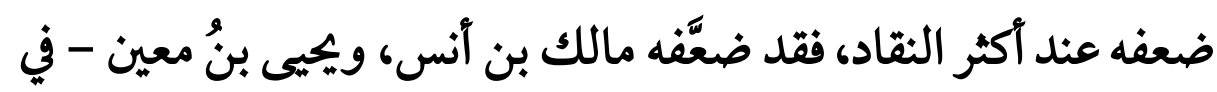

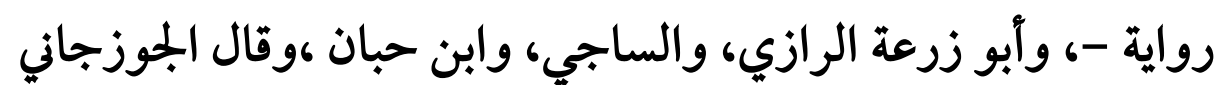

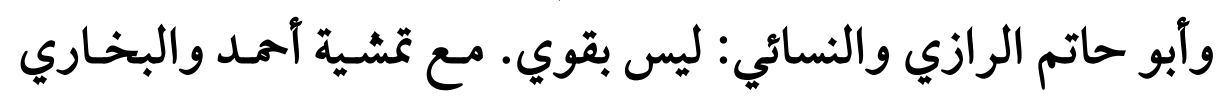

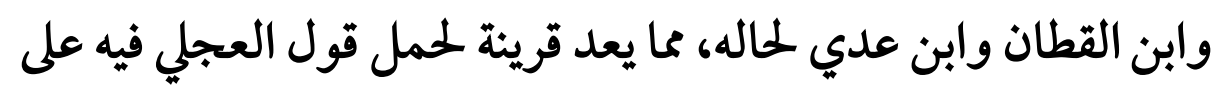

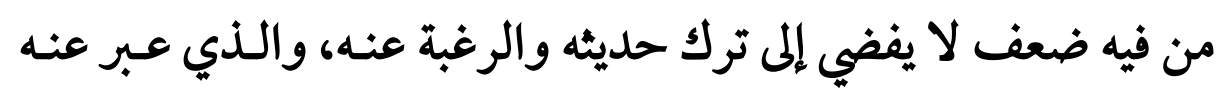
الحافظ ابن حجر: بقوله: صدوق سيء الحفظ.

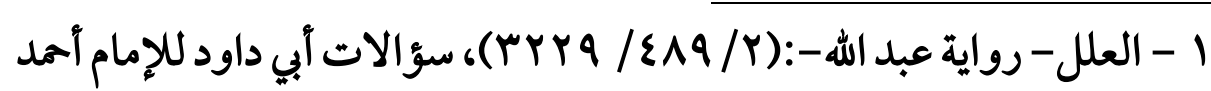

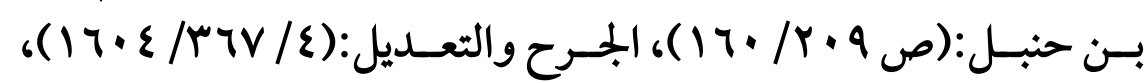

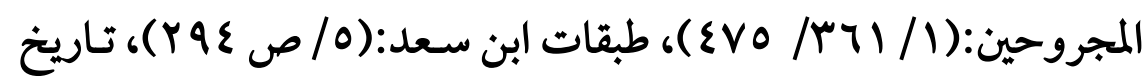

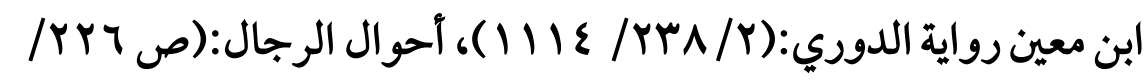

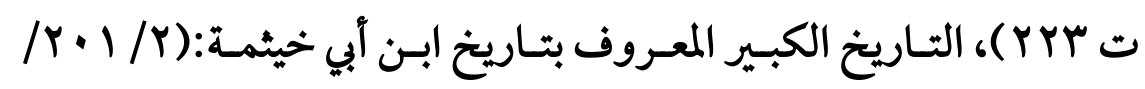

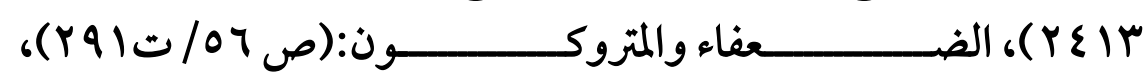

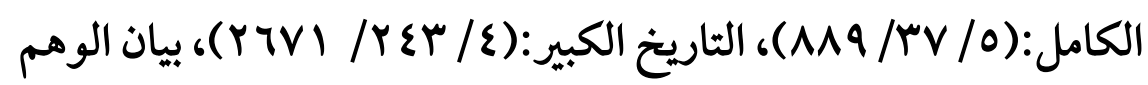

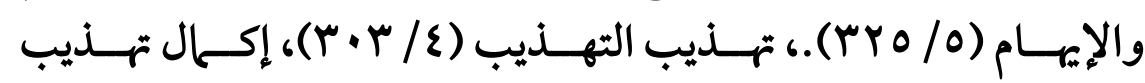

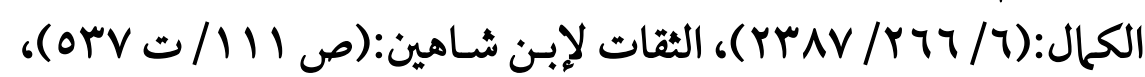

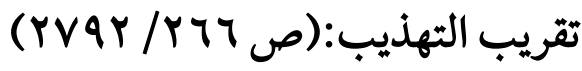




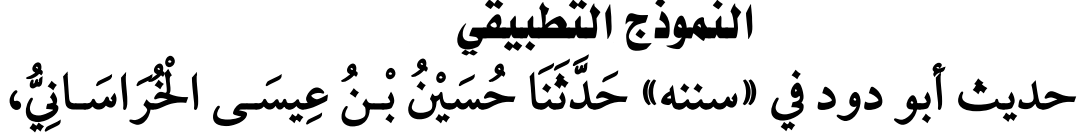

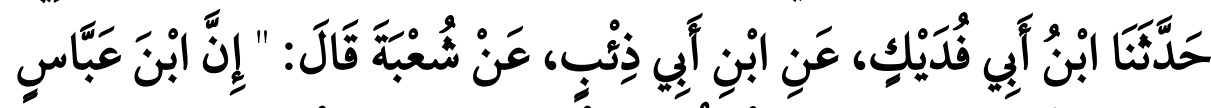

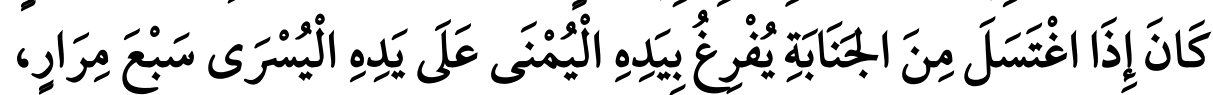

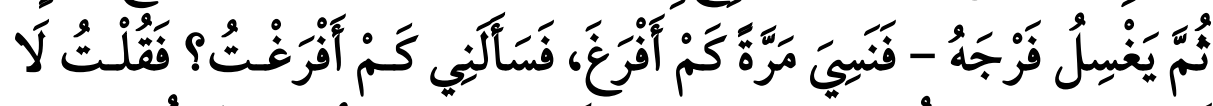

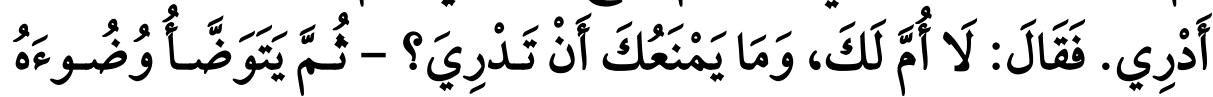

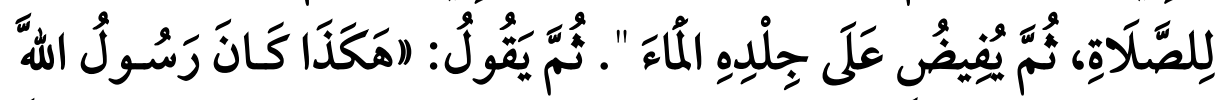

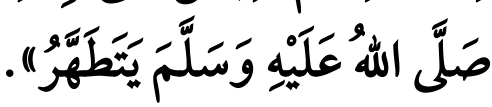

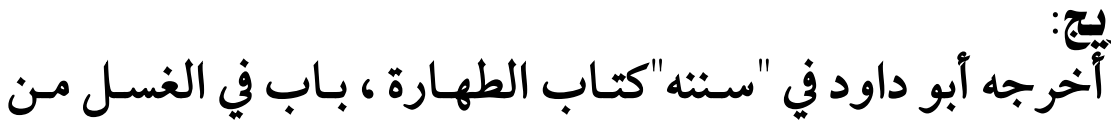

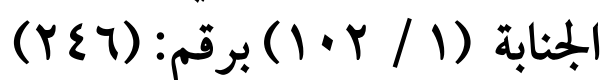

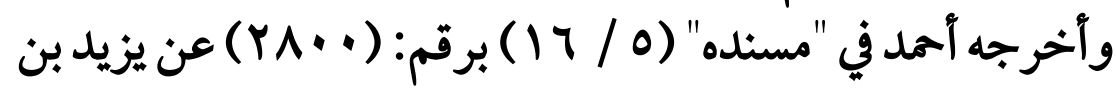

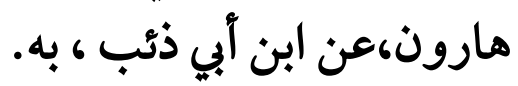

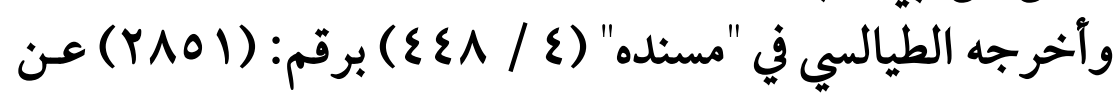

$$
\text { ابن أبي ذئب،هبه. }
$$

دراسة الإسناد:

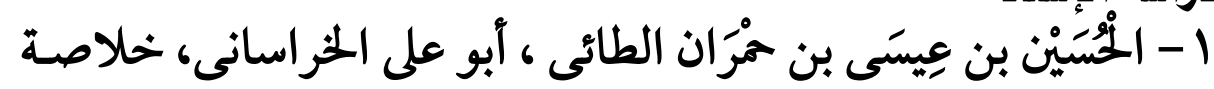

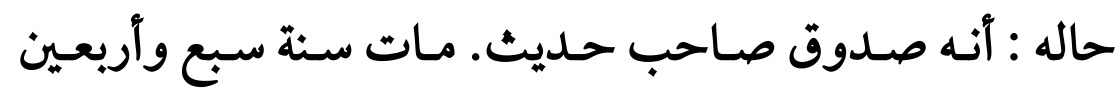
ومائتين. (1)

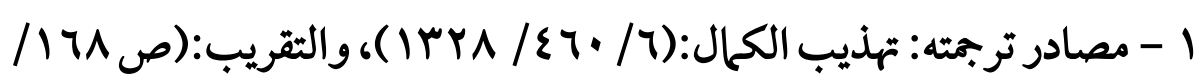


( $\vee \checkmark)$ جائز الحديث عند الإمام العجلي ودلاتله

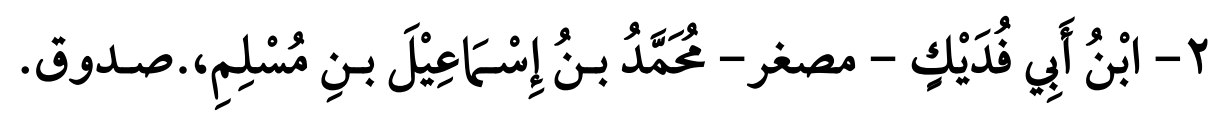

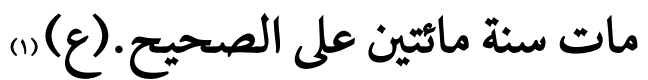

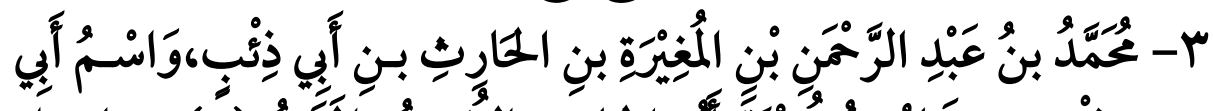

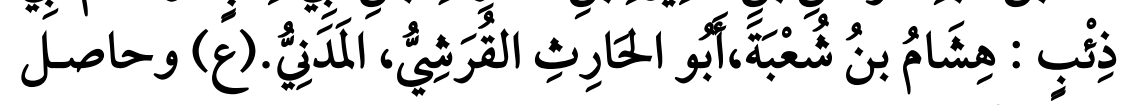

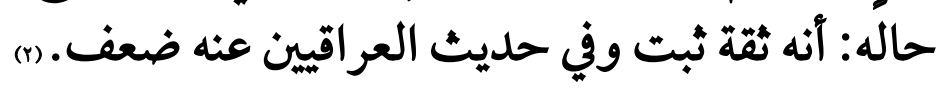

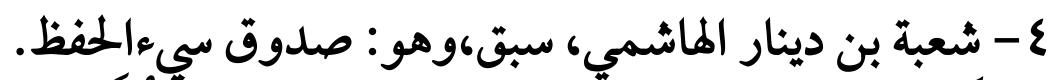

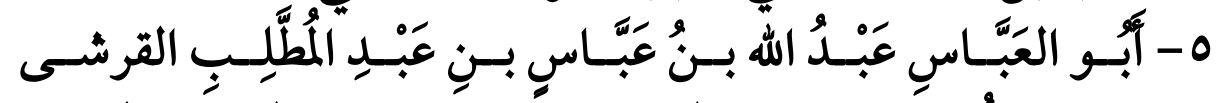

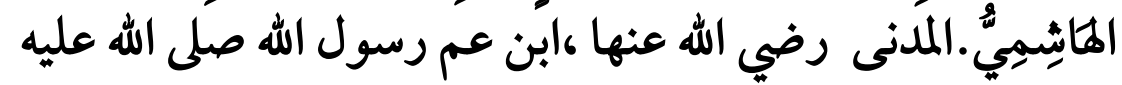

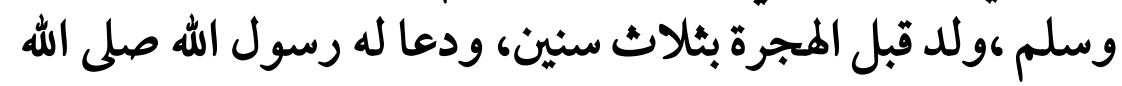

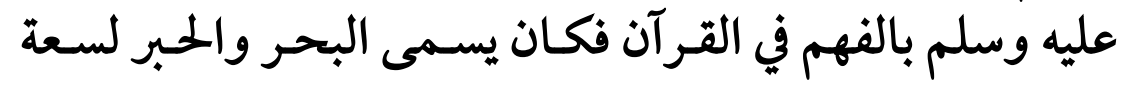

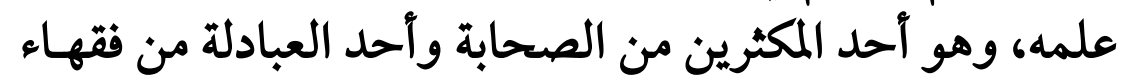

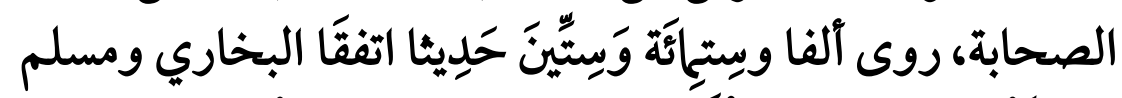

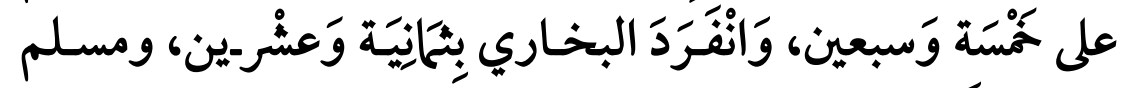

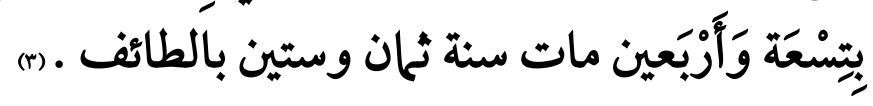

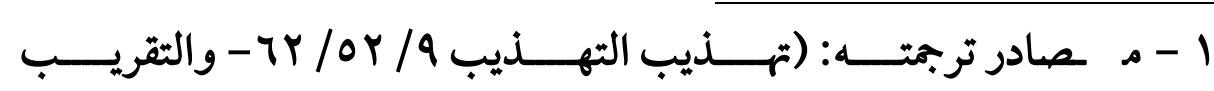

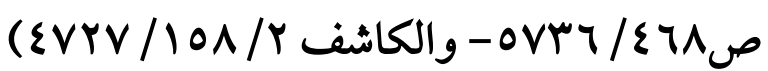

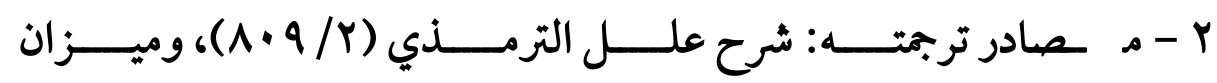

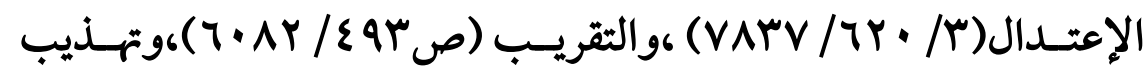

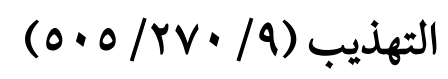

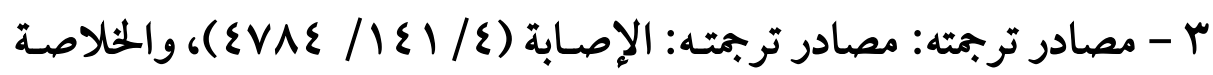
(ص r.r) 
$(\mathrm{v})$

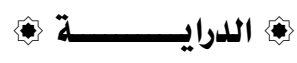

الحكم على الإسناد: ضعيف ، لضعف شعبة ولم أقف له على

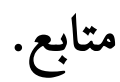

\section{التوجمة الثامنة}

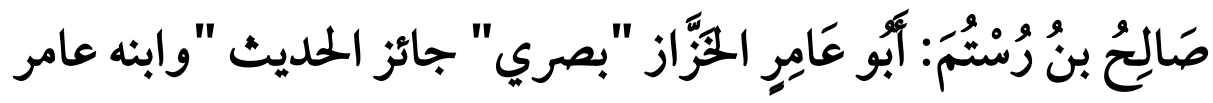

$$
\text { بن صالح: ثقة" (1). }
$$

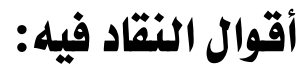

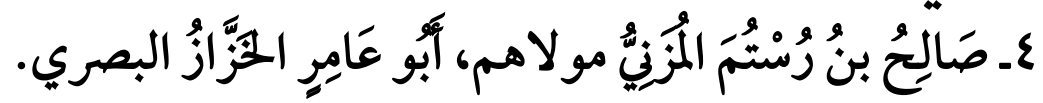

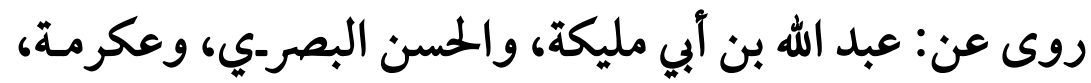

وروى عنه: أبو داود الطيالسي، ومعتمر بن سليان، وأبو عاصم

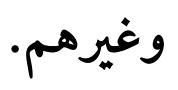

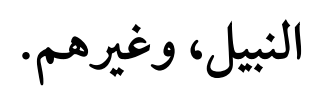

قال ابن معين: ضعيف وقال أيضًا: لا ثبيء. وقال الدارقطني:

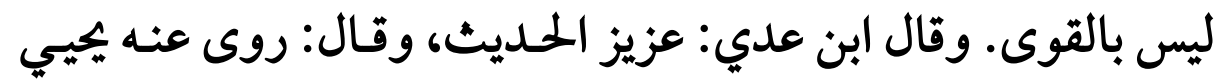

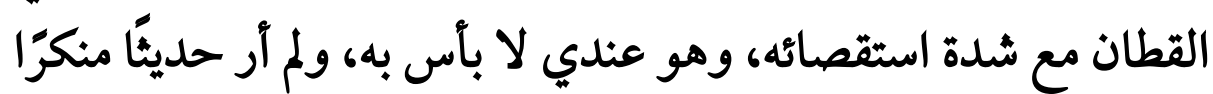

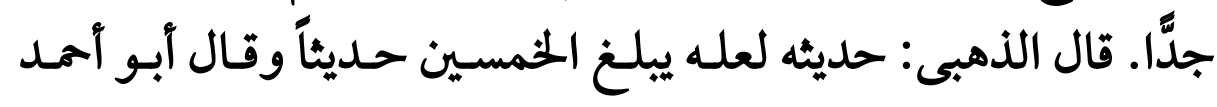

$$
1 \text { - معرفة الثقات (I/ص OrOT }
$$


$(\vee \wedge)$

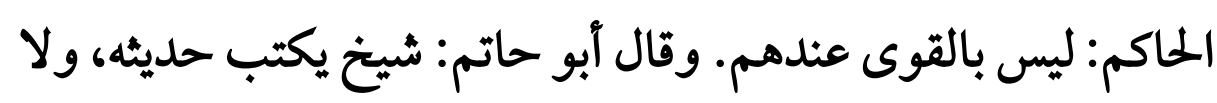

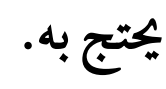

وذكره أبو العرب، والعقيلي، وابن البرقي في "(جملة الضعفاء).

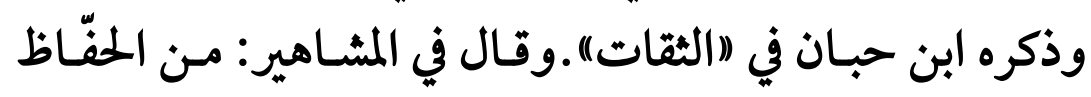

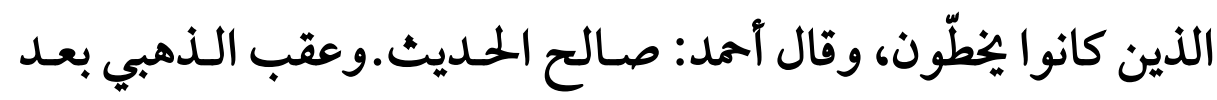

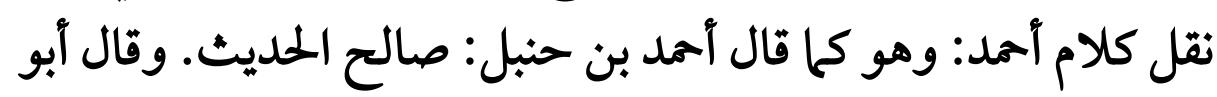

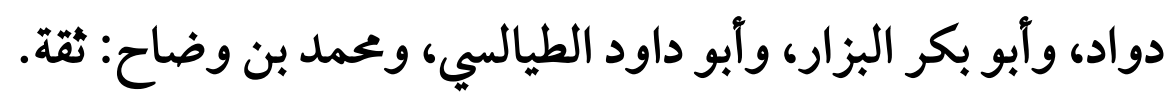

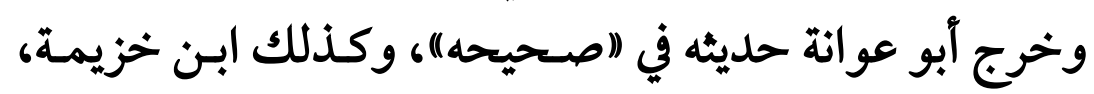

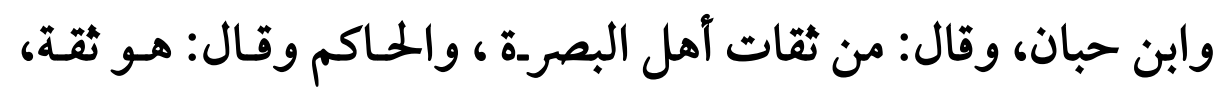

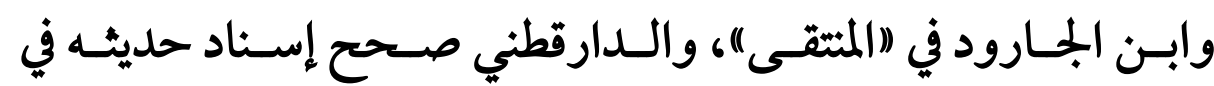
"(السنن)، ووذكره ابن خلفون وابن شاهين في ("جملة الثقات)، ز زاد ابن

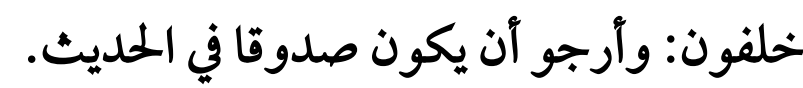

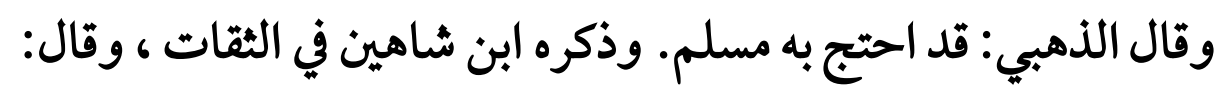

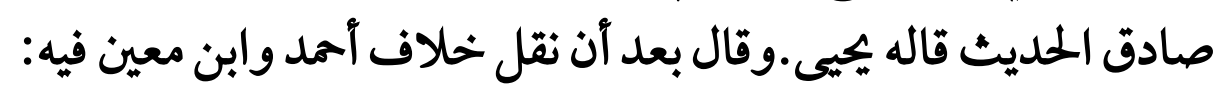

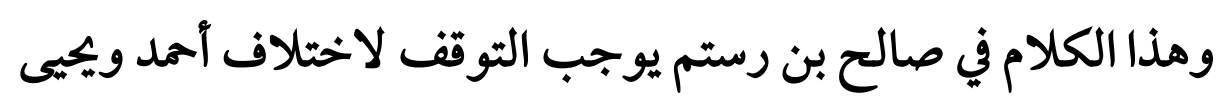

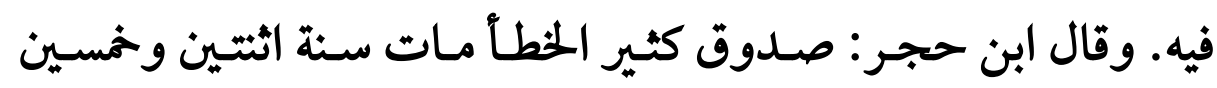
ومائة ونان

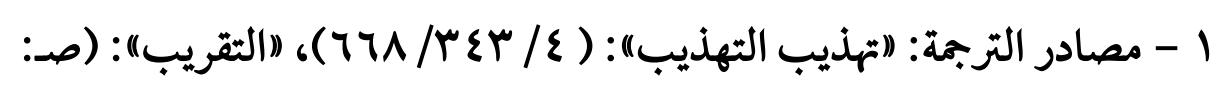
ا 


\section{المناقشة والترجيح}

بعد استعراض ومراجعة أقوال النقاد في صالح بن رستم يظهر اختلاف النقاد فيه،فقد وثقهه جماعة وضعفه جماعة من آهل العلم مع قلة

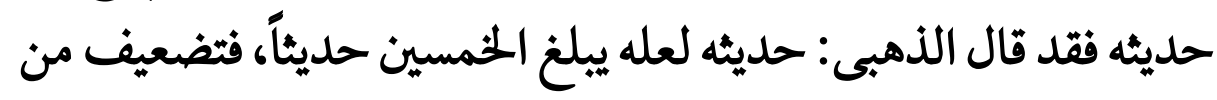

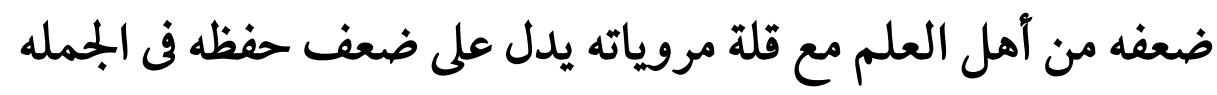
مع ثبوت عدالته. ومذا يعد قرينة خارجية للوقوف على دلالة عبارة الإمام العجلي

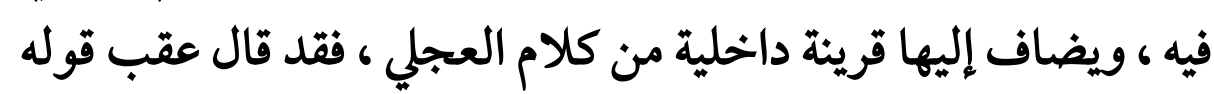

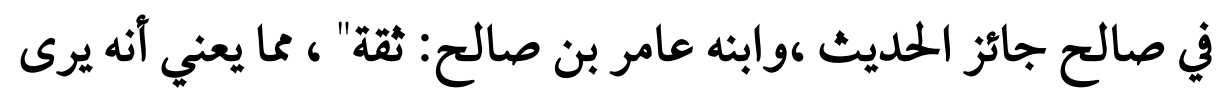

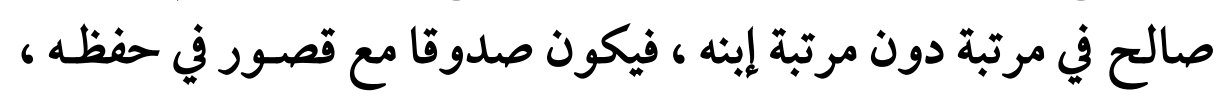
ويلتقي هذا مع قول الحافظ ابن حجر: صدوق كثيه دوريه الخطأ.

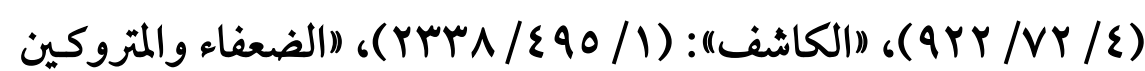

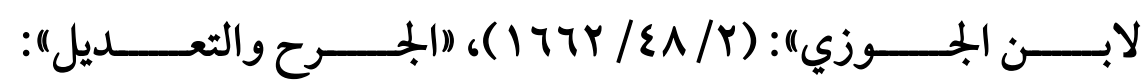

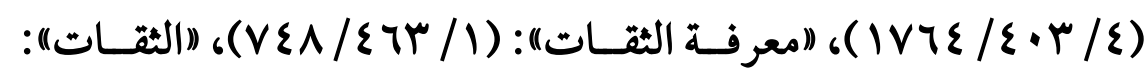

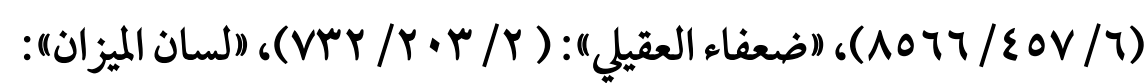

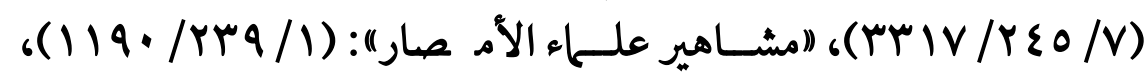

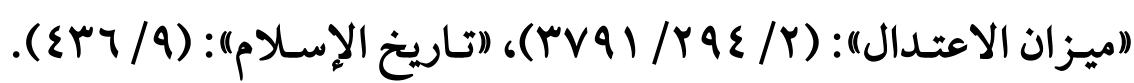

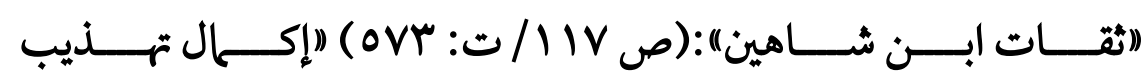

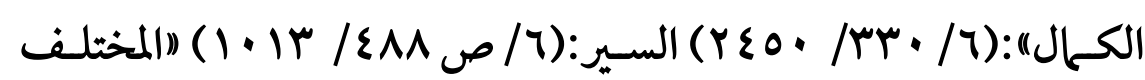

$$
\text { فيهم):(ص (V^) }
$$




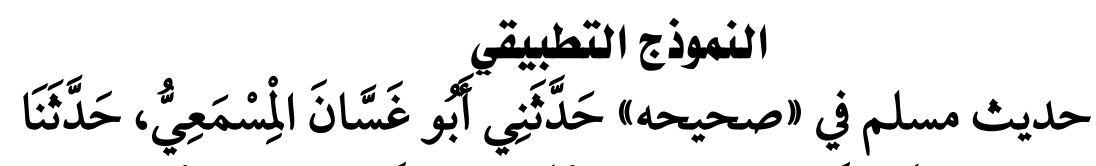

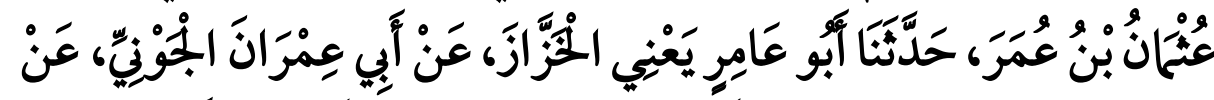

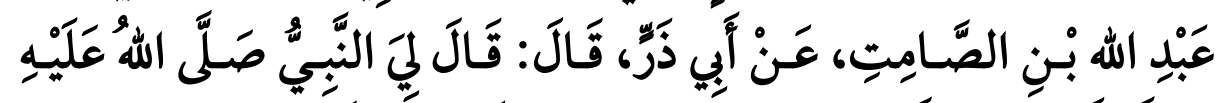

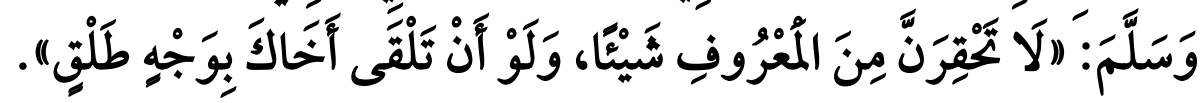

آخرجه مسلم في "صحيحه" كتاب البر والصلة والآداب ، باب

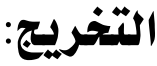

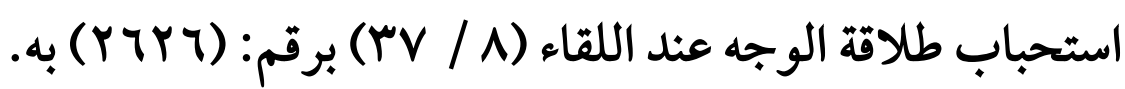
أخرجه مسلم في "صحيحه" كتاب البر والصلة والآداب ، باب لوناب

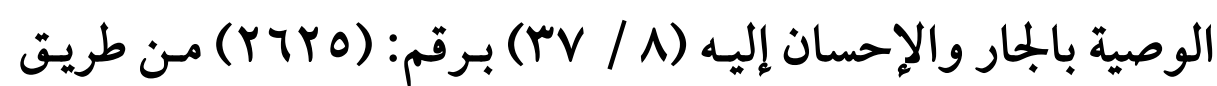

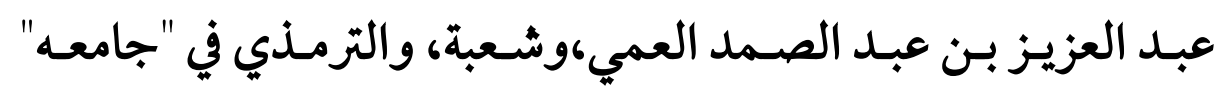

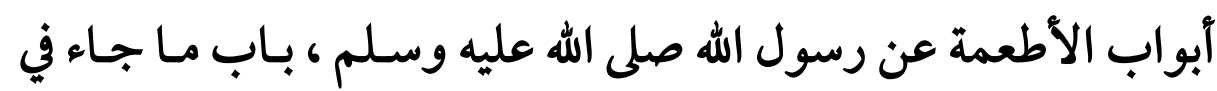

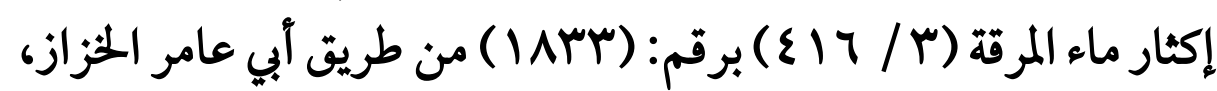

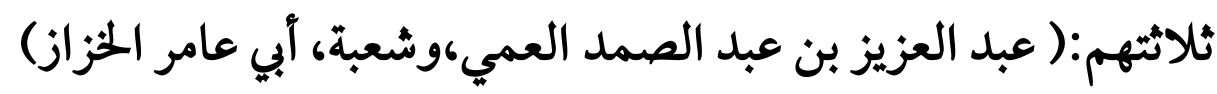

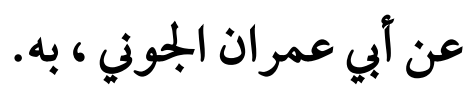
وقال الترمذي: هَذَا حَدِيثُ حَسَنْ صَحِيحُ وَقَدْ رَوَى شُعْبَةُ، عَنْ

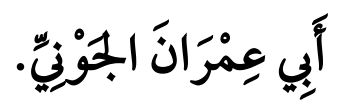


$(\wedge)$

\section{التزجمة التاسعة}

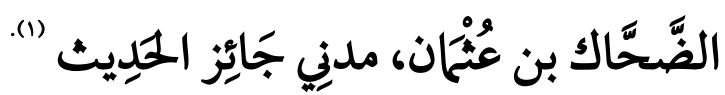

\section{أقوال النقاد فيه:}

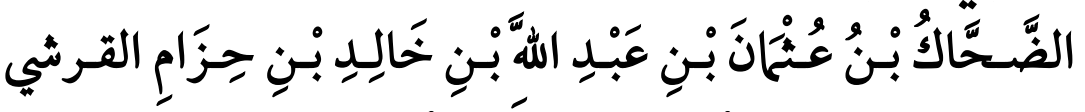

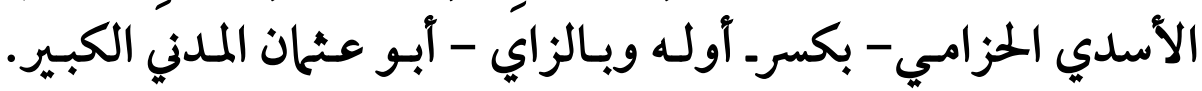

$$
(\varepsilon, p)
$$

روى عن: نافع مولى ابن عمر، وزيد بن أسلم وسعيد المقبري،

وغيرهم.

روى عنه: ابنه عثمان، وابن ابنه الضحاك، والثوري ، وغيرهم.

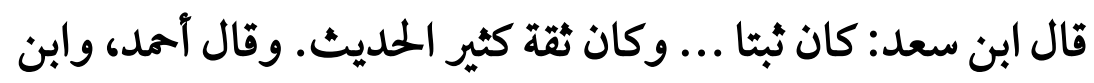
معين، وعلي بن المديني ،ومصعب الزبيري، ابن بكير: ثقة، وفي رواية عثئان

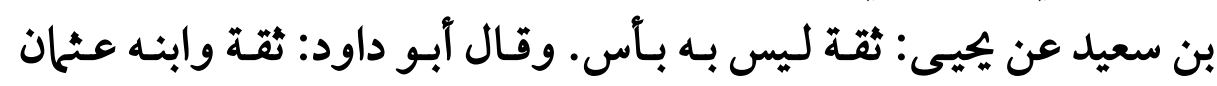
ضعيف.

وذكره ابن حبان في الثقات ، وقال في المثـاهير: مـن المتقنين وآهـل

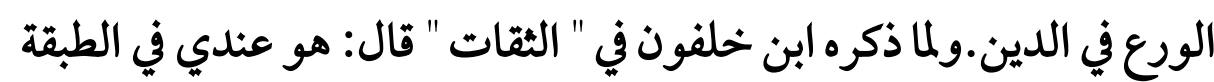
الثالثة من المحدثين، وقال ابن نمير: لا بأس به جاتئز الحديث.

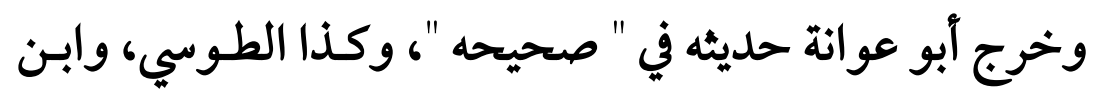

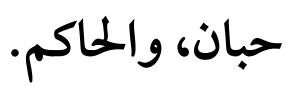

$$
1 \text { - معرفة الثقات (I/ص }
$$


$(\wedge r)$

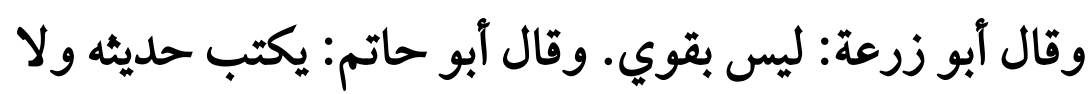

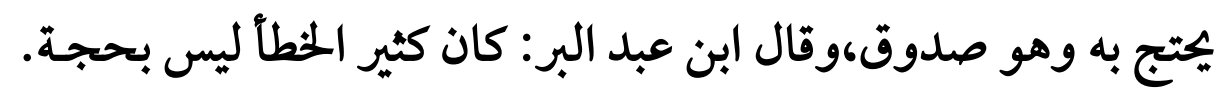

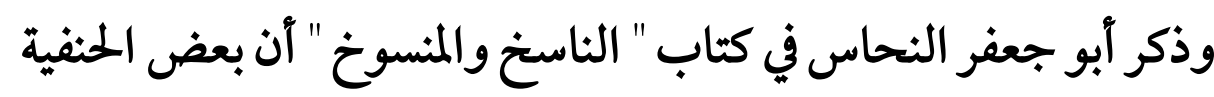
قال: هو بجهول ورد ذلك عليهم. وقال ابن حجر: صـدوق يهم. ومدردات بالمدينة سـنة ثلاث وخمسين ومائة ونال

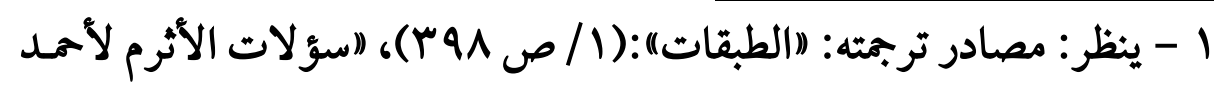

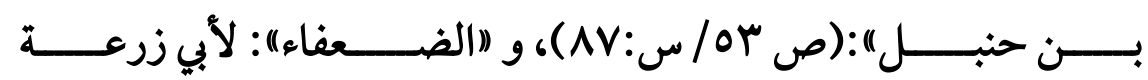

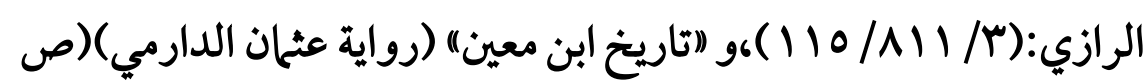

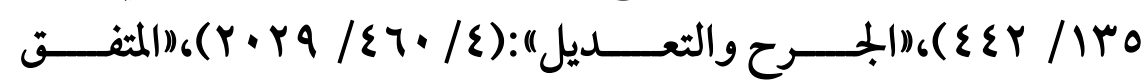

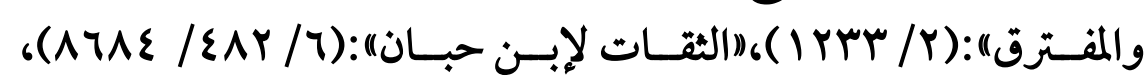

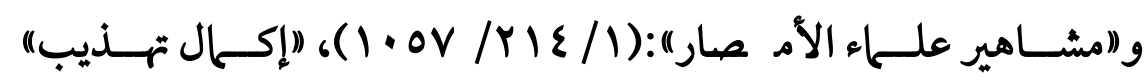

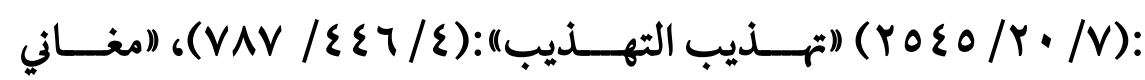

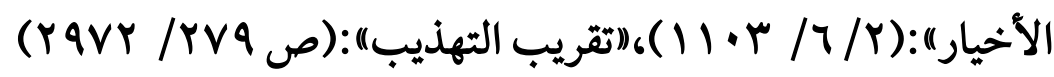




\section{المناقشئة والتزجيح:}

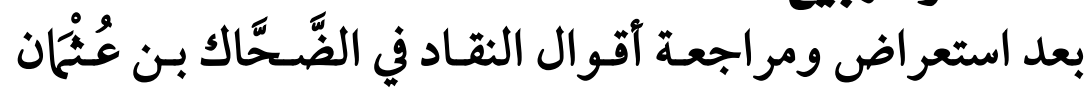

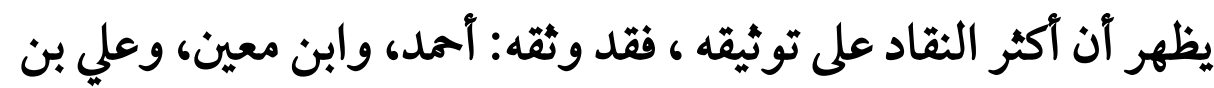

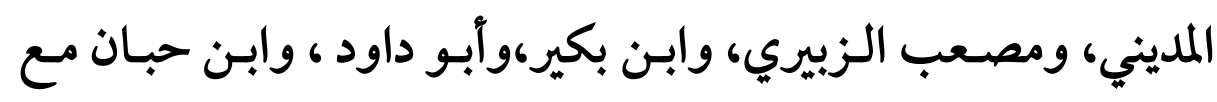
تشدده.

وقول أبو زرعة: ليس بقوي ، ليس بجـرح مفسـد ، فقـد قال

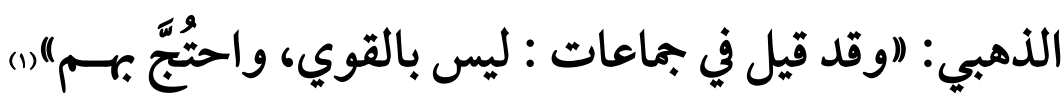
وقول أبو حاتم: يكتب حديثه ولا يحتج بـه وهـو صـدوق، مـن

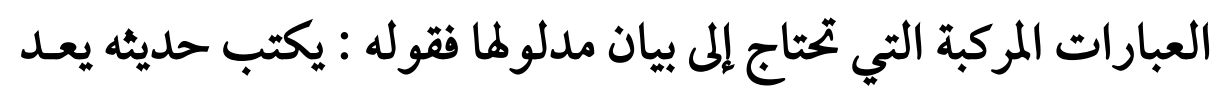
من المرتبة السادسة من مراتب التعديل، وهي أدنى مراتبه(r)، وقد ذكر ليكر

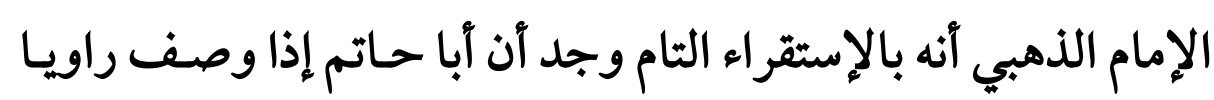

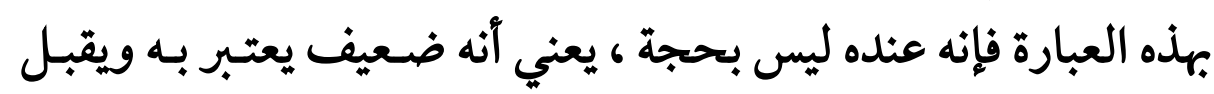

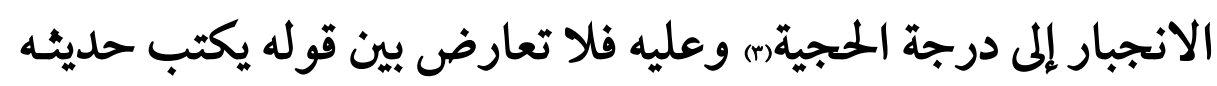

$$
\begin{aligned}
& \text { 1 - الموقظة (صrr-Ar) }
\end{aligned}
$$

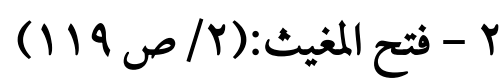

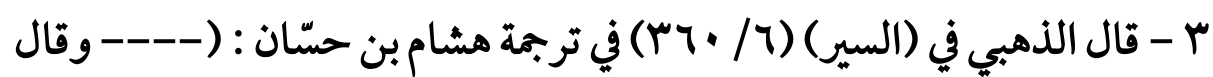

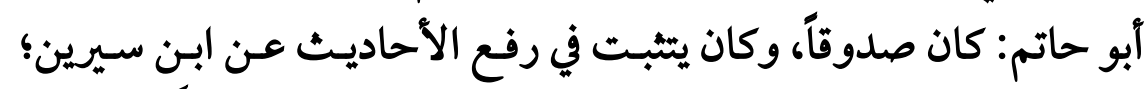

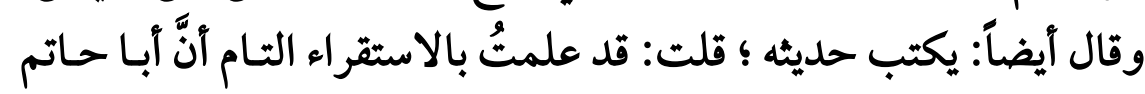

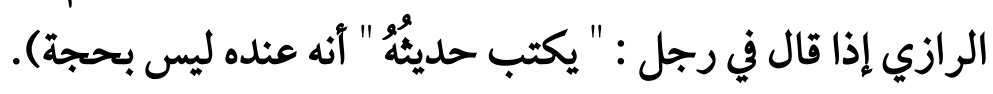


وقوله لا يحتج به ، وأما صدوق: فقد جعلها ابن أبي حاتم( (1)في المرتبة

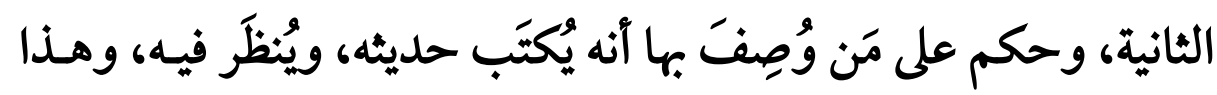

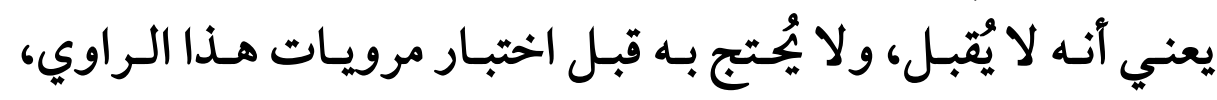

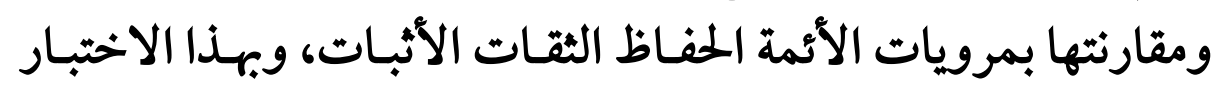

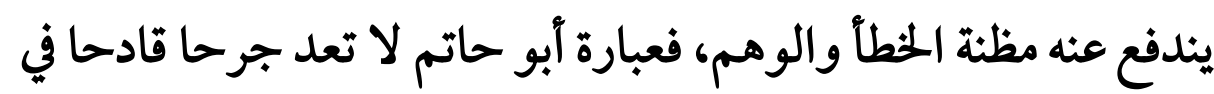

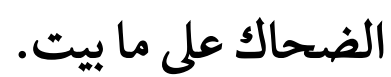

وأما قول: ابن عبد البر: كان كثير الخطأ ليس بحجة، فلم آقف

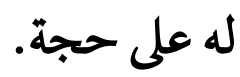
وعليه يمكن حمل حال الضحاك على الصدوق في روايته، ومي مرتبة حسن الحديث عند الجمهور،،وتفسر عبارة العجلي هنا بالصدوق

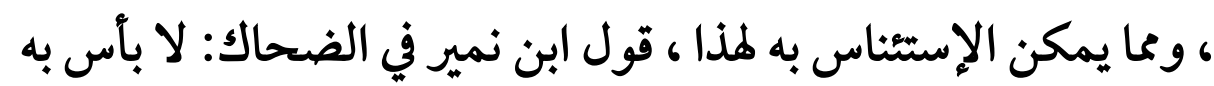

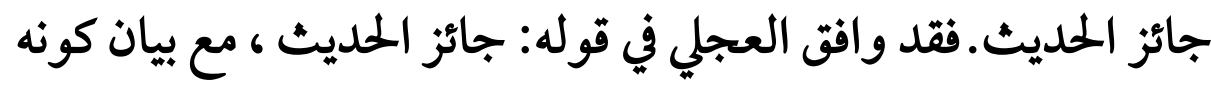
لا بأس،وهي مرتبة حسن الحديث مما يرجح تفسير جائز الحديث فيث هنا

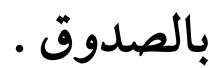

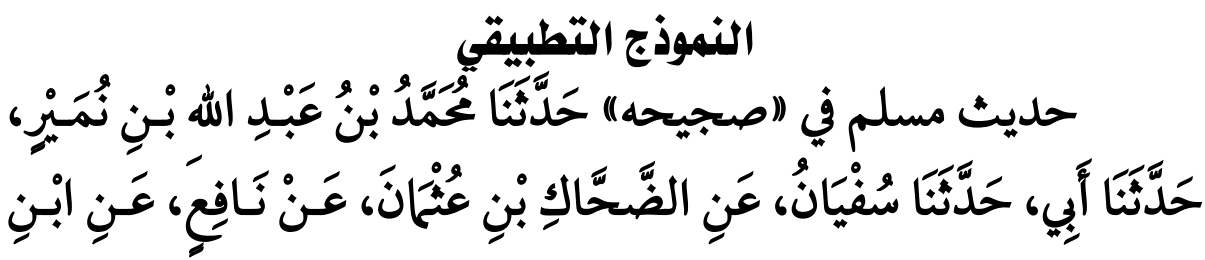
() ينظر: (الجرح والتعديل): (Y) (YV). 
(^०)

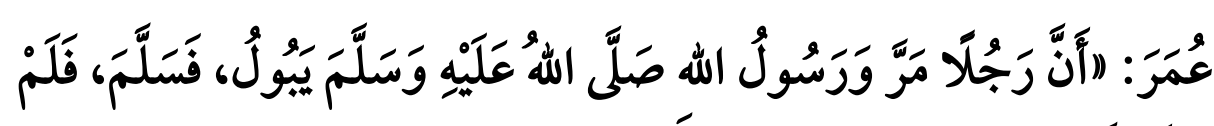
يَرِدَّ عَلَيْهِهِ.

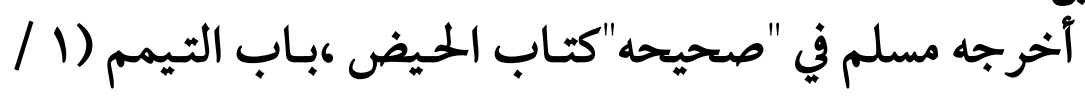

التخريج:

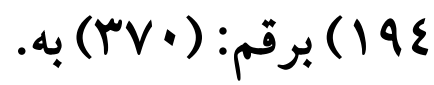

وآخرجه أبو داود في "سننه"كتاب الطهارة ، باب في الرجل يرد

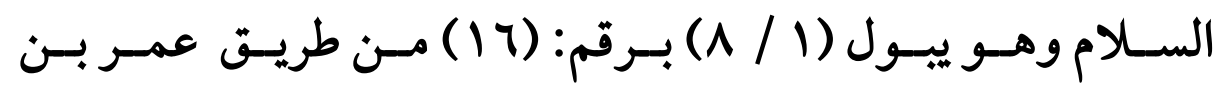
سعد،والترمذي في "سننه" أبواب الطهارة عن رسول الله صلى الله عليه

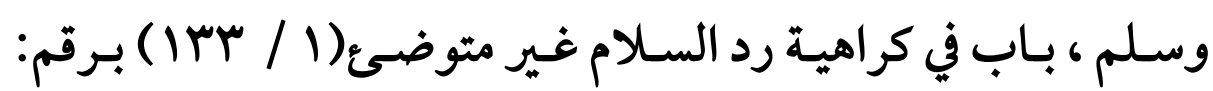

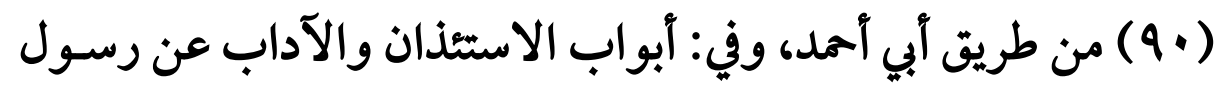

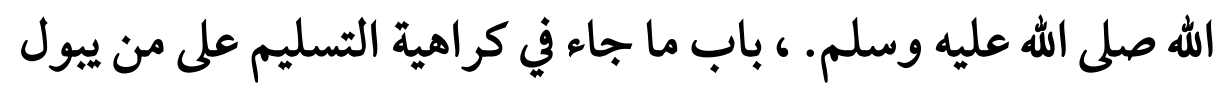

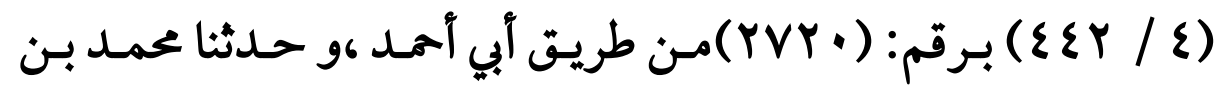

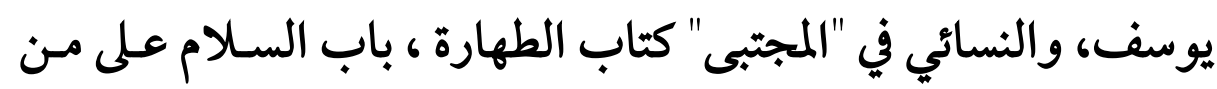

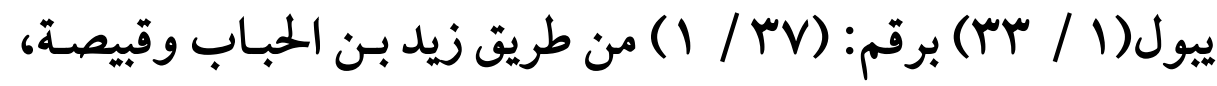

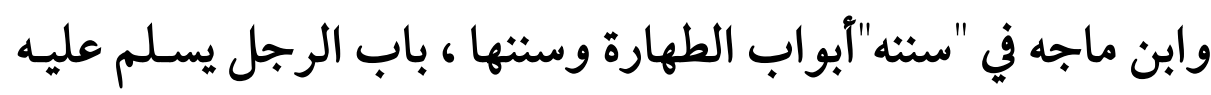

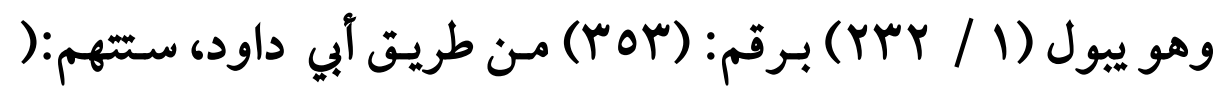

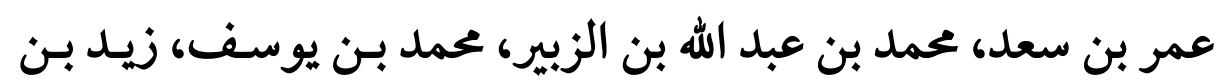
الحباب وقبيصة، أبو داود)عن سفيان ، به.

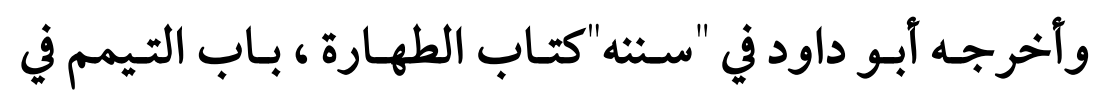

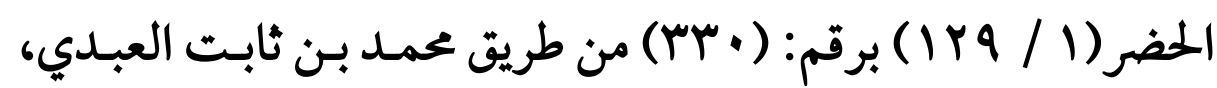


(^५)

جائز الحلديث عند الإمام العجلي ودلالته

ويرقم: (اسMr) من طريق ابن الماد،كلامما: (محمد بن ثابت، وابن الماد)

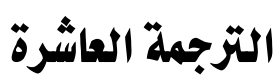

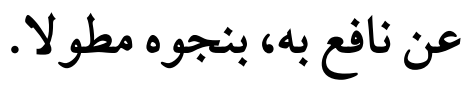

يَزِيدُ بْنُ عَطَاءٍ "الواسطي" جائز الحلديث، وأبو عوانة أرفع

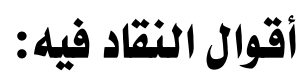

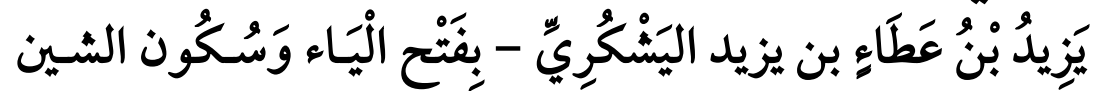

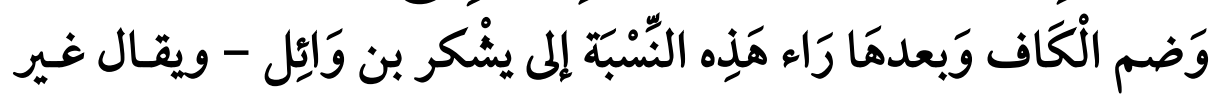

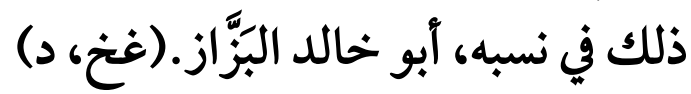

روى عن: سماك بن حرب، وإسماعيل بن أبي خالد، وييان بن

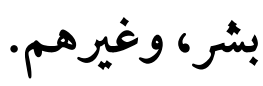

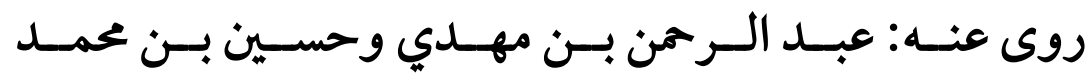

المروزي،وعبد القدوس بن الحجاج، وغيرهم.

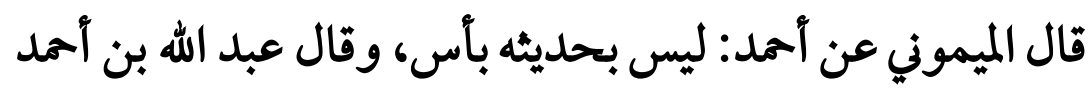

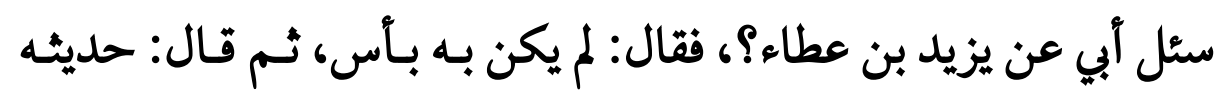

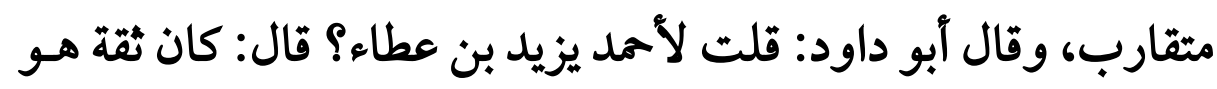

1 - معرفة الثقات (1/ص •1^/ج 
مولى أبي عوانة من فوق مقارب الحديث، وقال أحمد بن أبي يجيى ،عن أمد: ليس بقوي في الحديث.

وقال الدوري عن ابن معين: ليس بقوي، وقئ وقال مـرة عن ابن

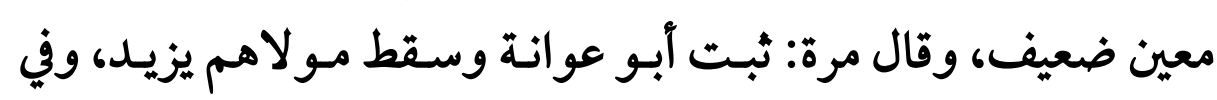

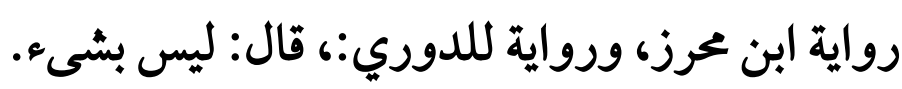

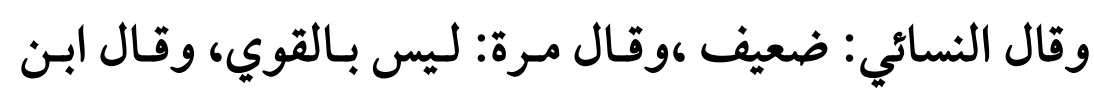

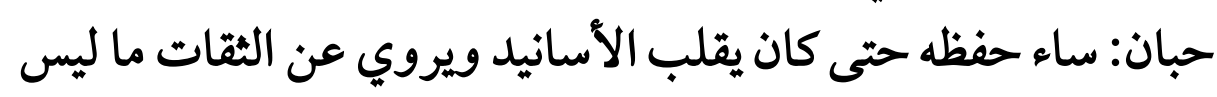

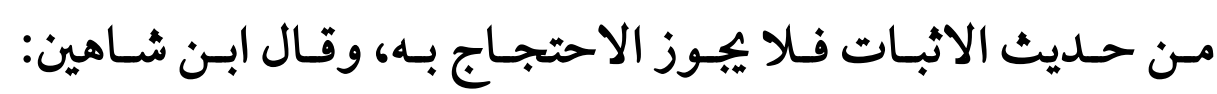

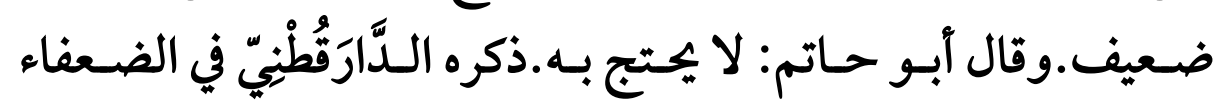

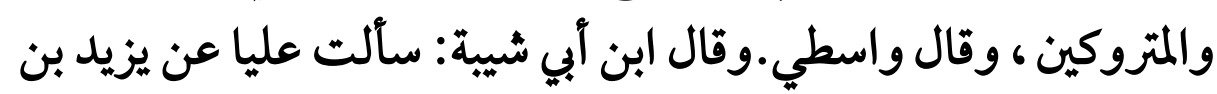
عطاء فقال كان ضعيفا وهو من موالي أبي عوانه. وقال ابن سعد: يزيد بن عطاء البزاز مولى أبي عوانة مـن فوق، أبعانه

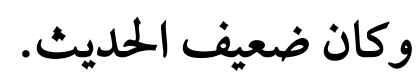
وقال ابن عدي: ويزيد بن عطاء مع لينه حسن الحديث الحيث وعنده

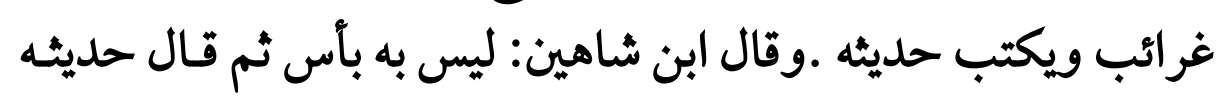

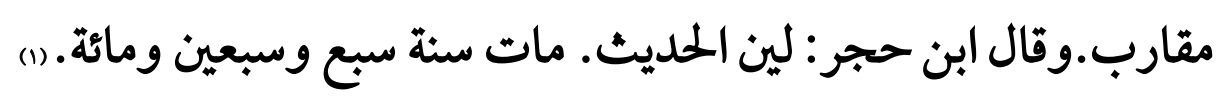

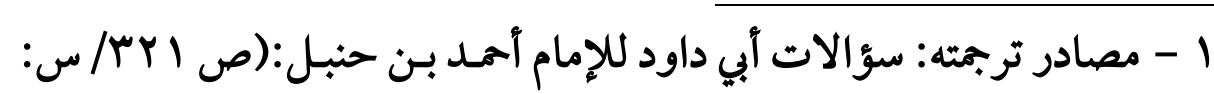

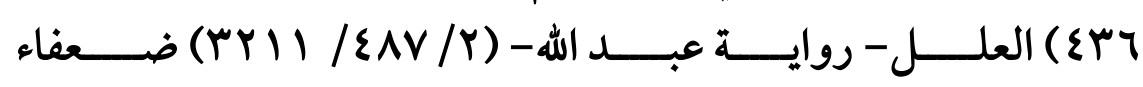

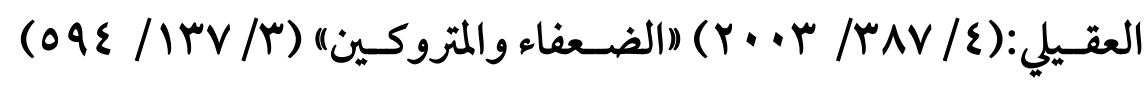




\section{المناقشة والترجيح}

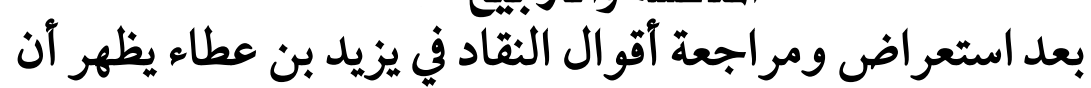

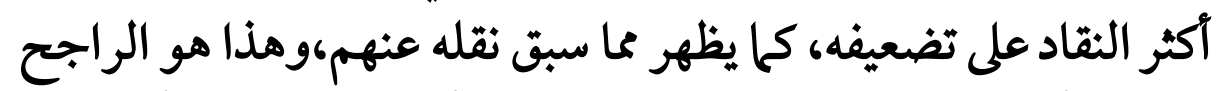

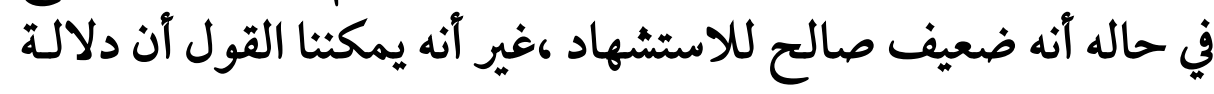

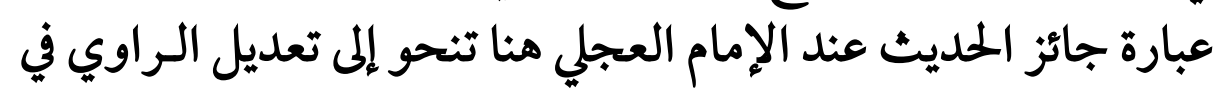

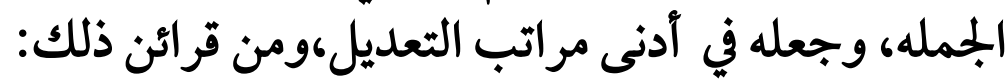

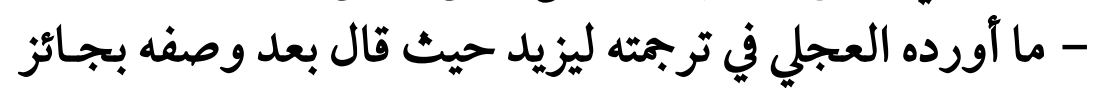

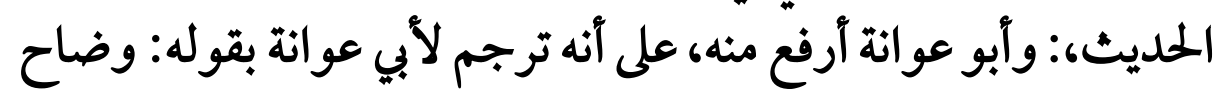

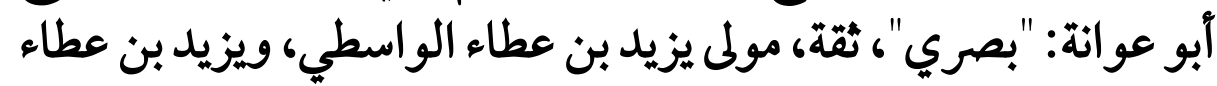

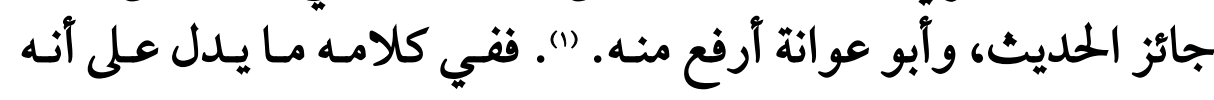
مقارب لمرتبة الثقة.

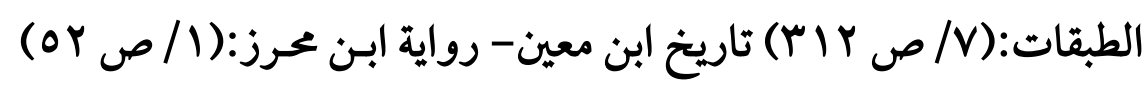

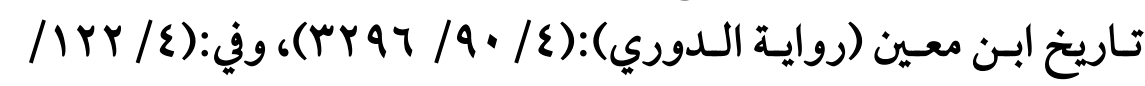

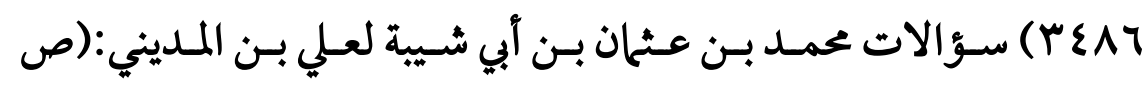

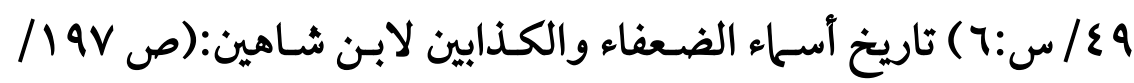

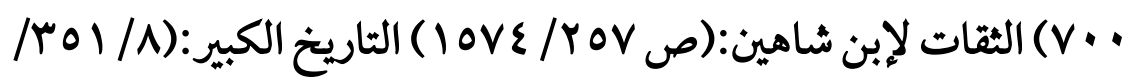

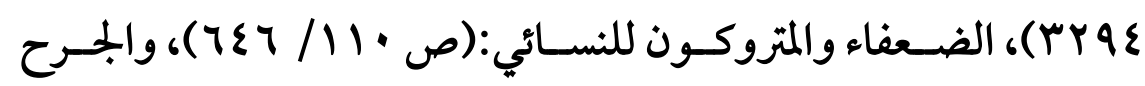

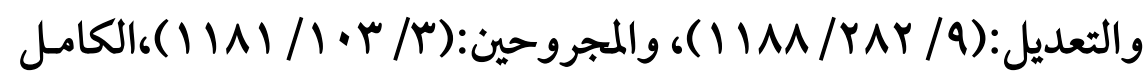

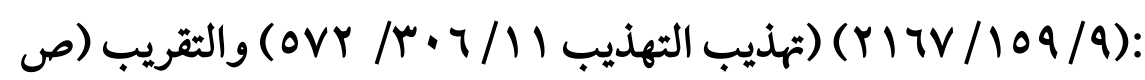

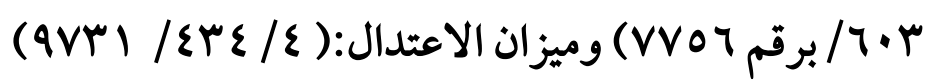

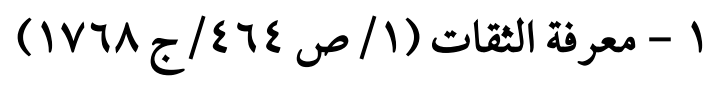


(19)

ويلتقي هذا مع وصف الإمام أمد- في إحدى الروايات عنه-

ليزيد بقوله: كان ثقة هو موله أبي عوانة من فوق مقارب الحمديث.

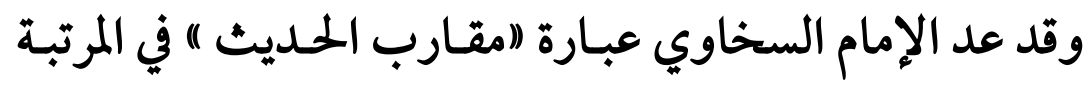

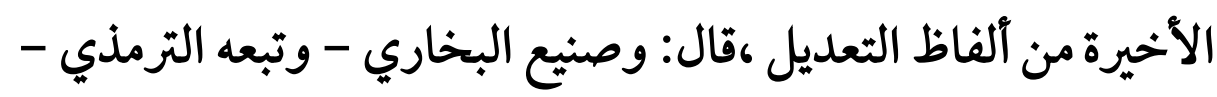

يؤيله (1)

النموذج التطبيقيَ

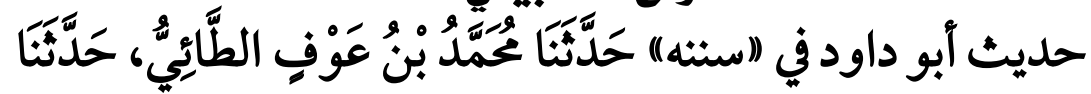

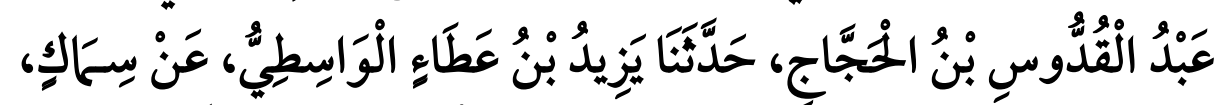

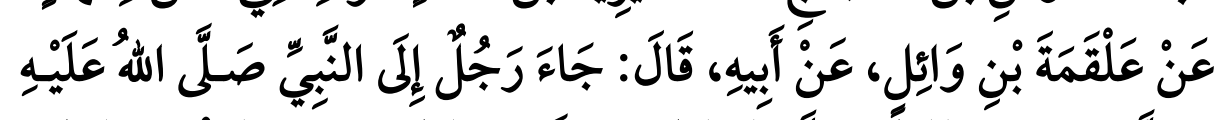

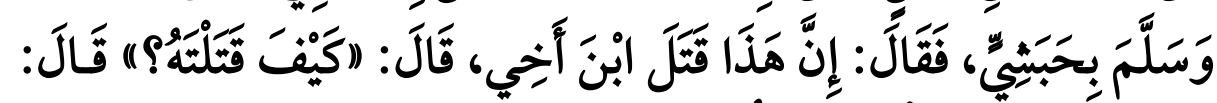

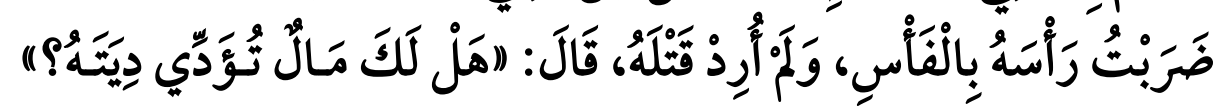

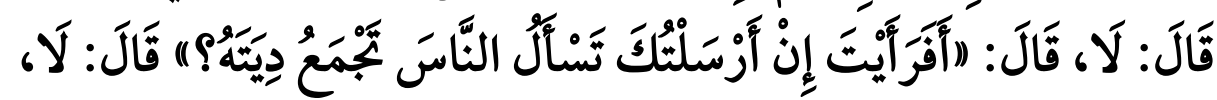

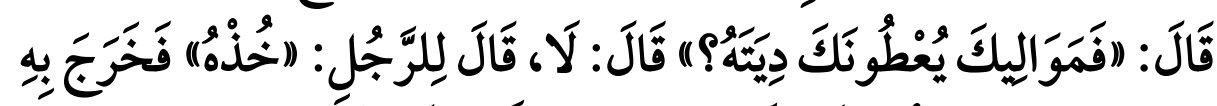

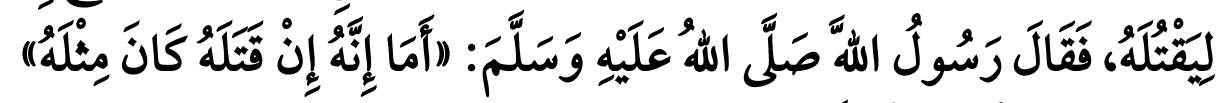

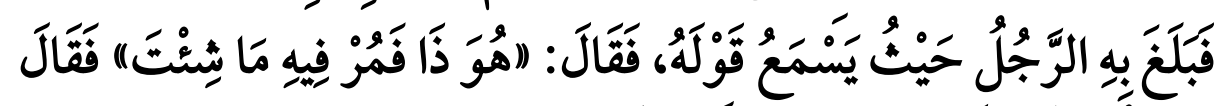

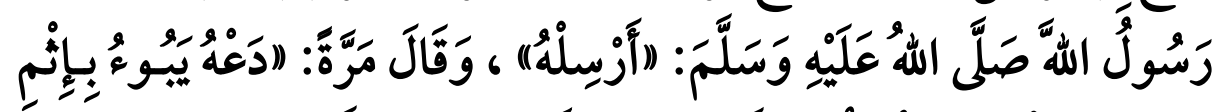

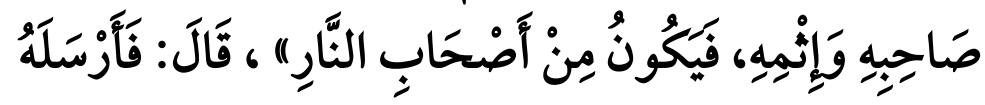

| - الغاية في شرح المداية في علم الرواية:(ج / ص ع Y ) 
أخرجه أبو داود في "سننه" ،كتاب الديات ، بـاب الإمام يأمر

\section{التخريج: - (التيج}

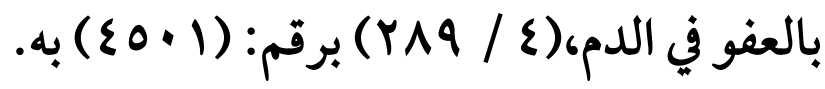

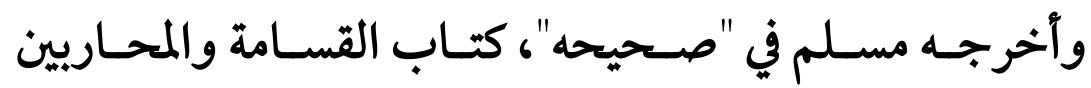

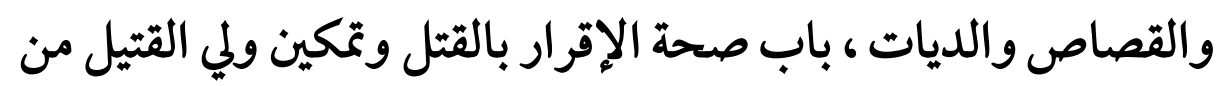

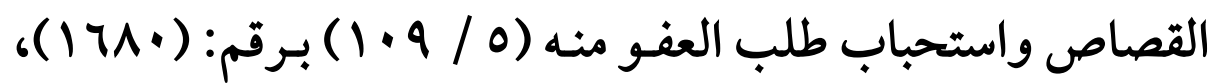

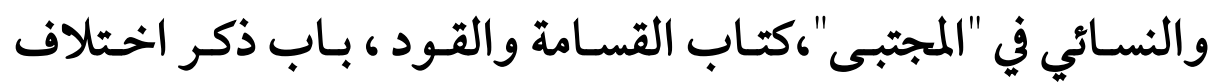

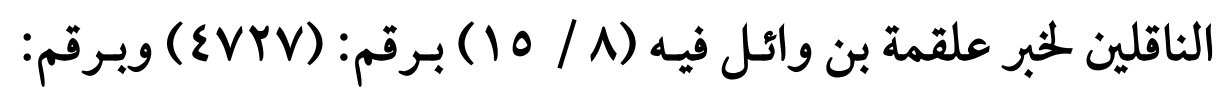

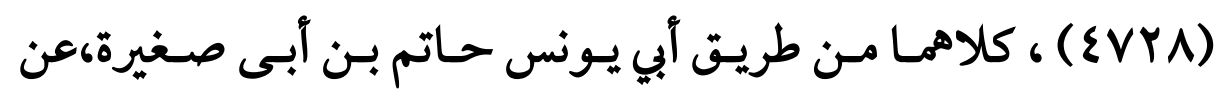
سملك،به، بمعناه مطولا.

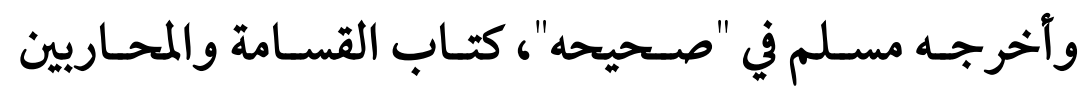

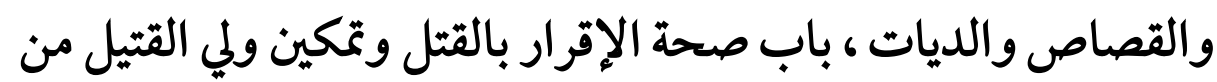

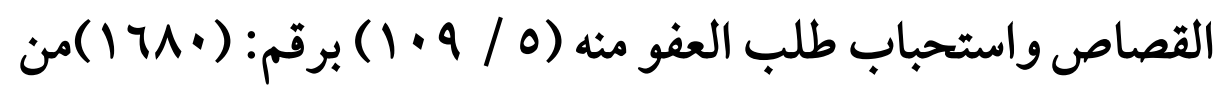

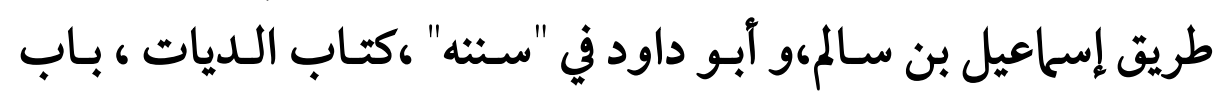

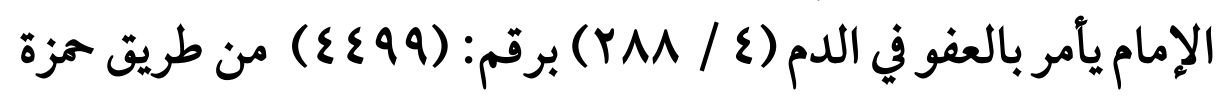

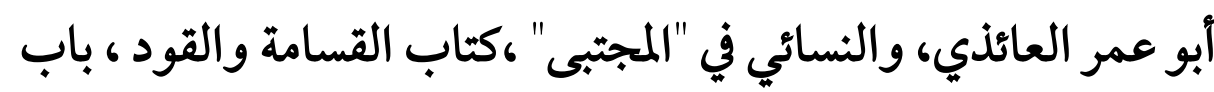

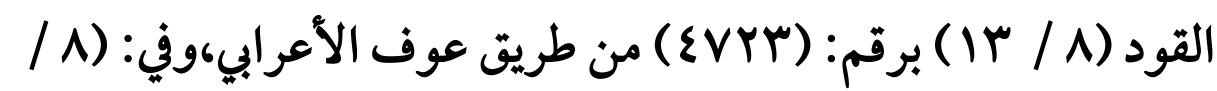

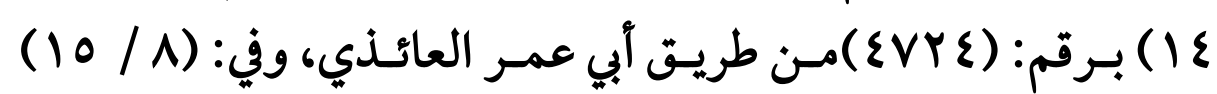

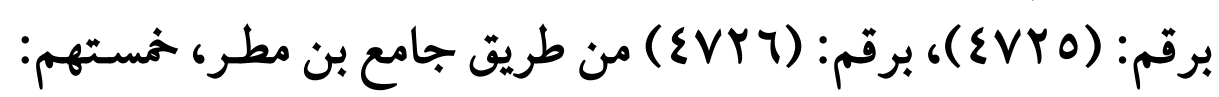




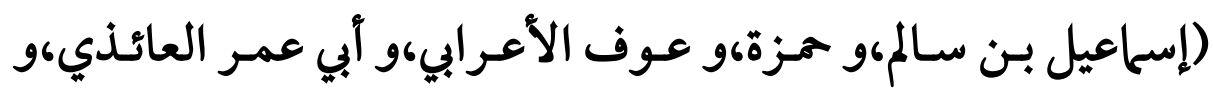
جامع بن مطر) عن علقمة، به ، بمعناه، وعند مسلم بمعناه غختصوفرا. دراسة الإسناد:

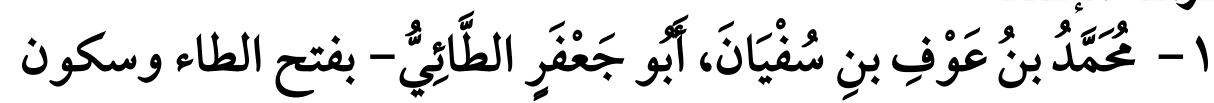

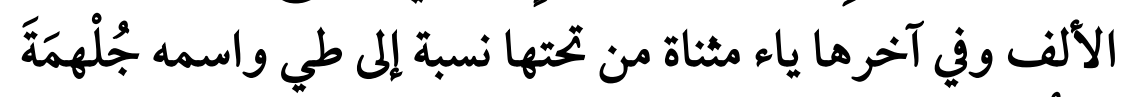

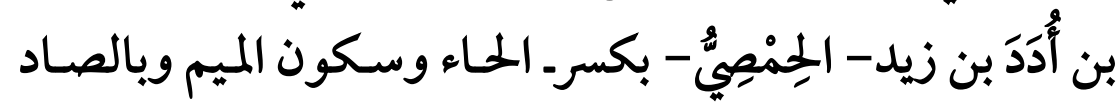

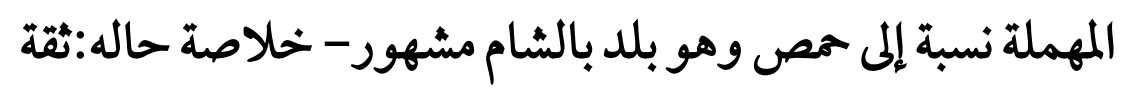

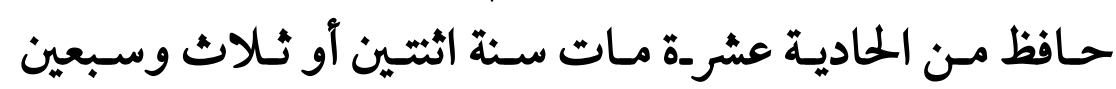

$$
\text { ومائتين. (د،عس) من (1) }
$$

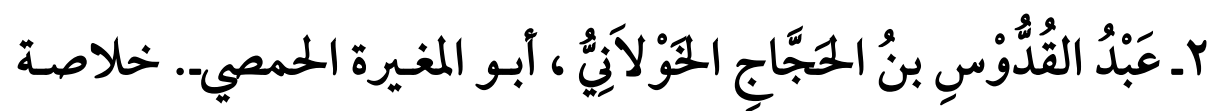

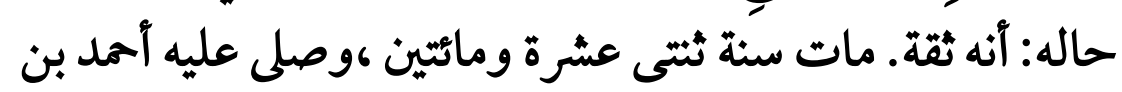

$$
\text { حنبل • (r) }
$$

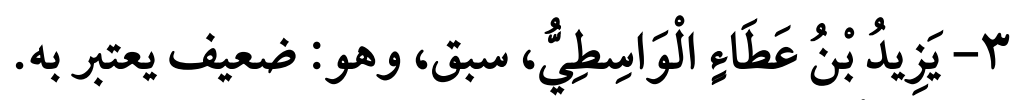

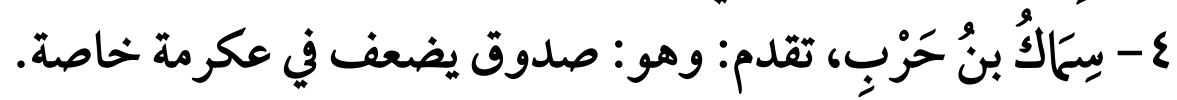

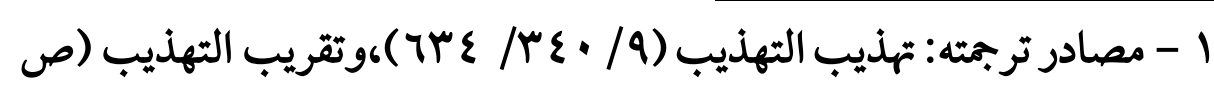

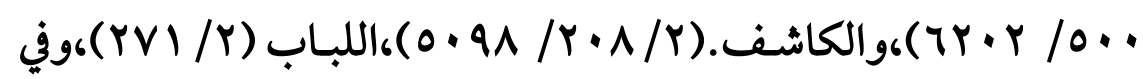

$$
(r \wedge 9 / 1)
$$

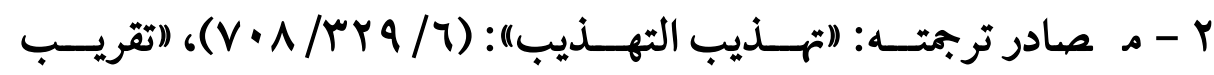

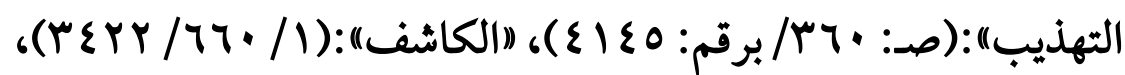


$(94)$

جائز الحديث عند الإمام العجلي ودلالته

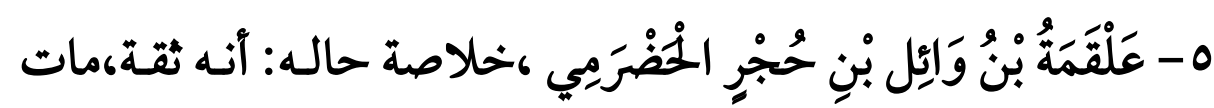

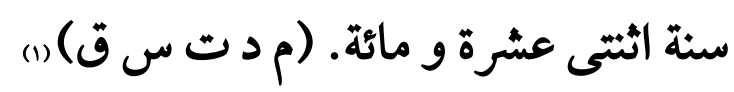

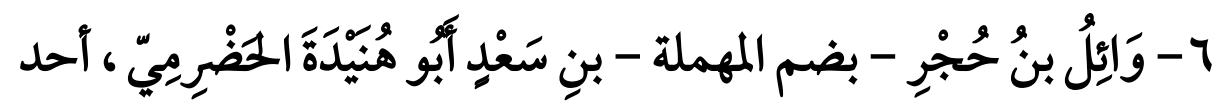
الأشراف، كان سيد قومه ، له: وفادة، وصحبة، ورواية، له أحد

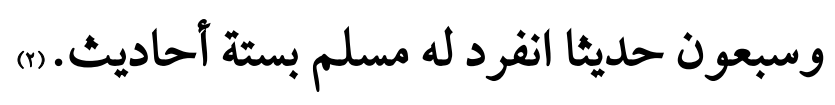

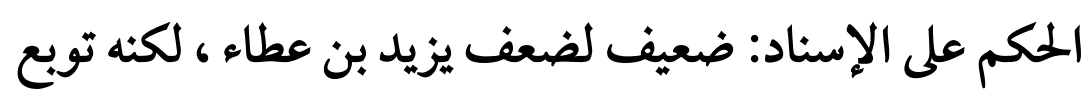

من غير وجه عند مسلم وغيره مما يرقيه للحسن لغيره. التوجمة الجادية عشرة

يَزيْيُدُ بُن أَبِي ِِيَادِ مولى بني هاشَم: "كوفي"، جائز الحديث، وكان

بآخرة يلقن.

\section{أقوال النقاد فيه:}

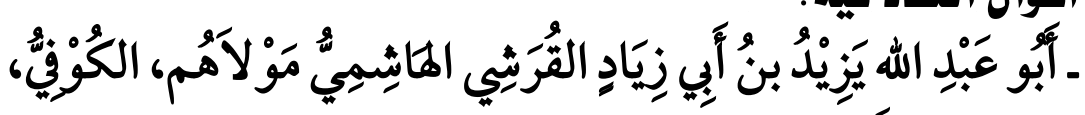

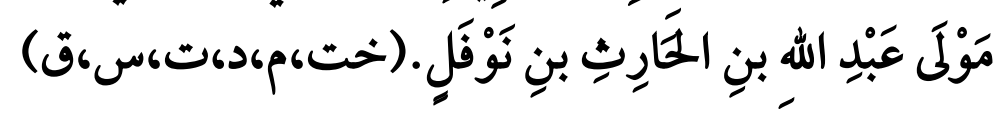

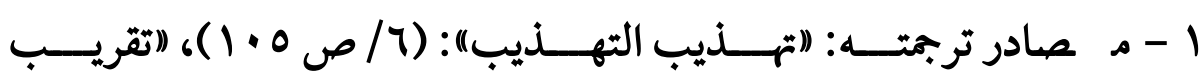

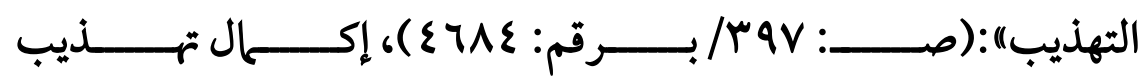

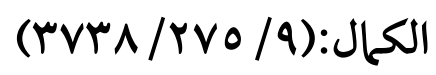

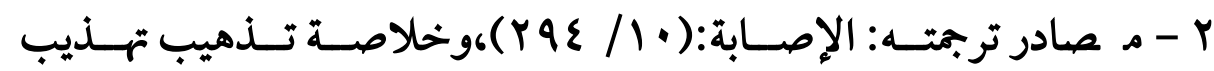

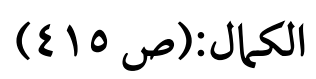

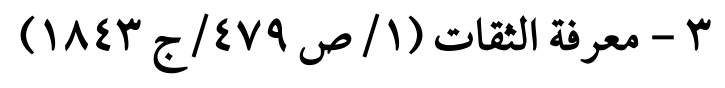




$$
\text { روى عن: بُجَاهِد، وأبي الأحوص وغيرهما. }
$$

وروى عنه: معمر بن راشد، وإسماعيل بن أبي خالد، وغيرهما. والها.

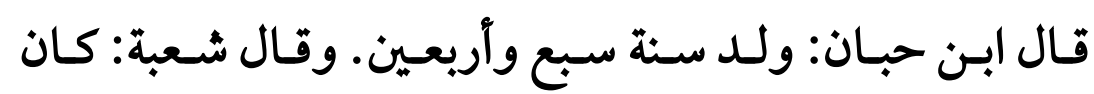

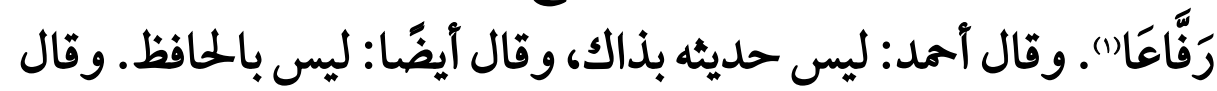

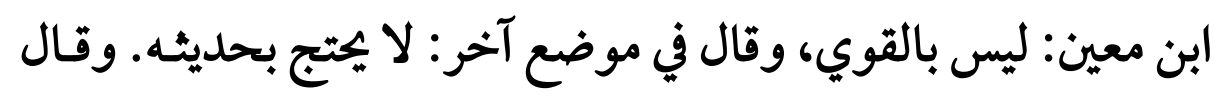

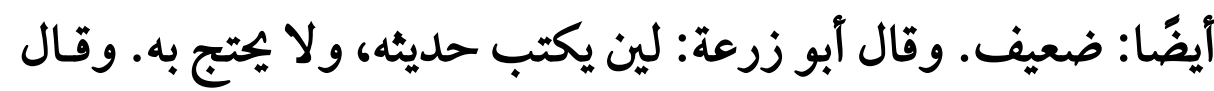

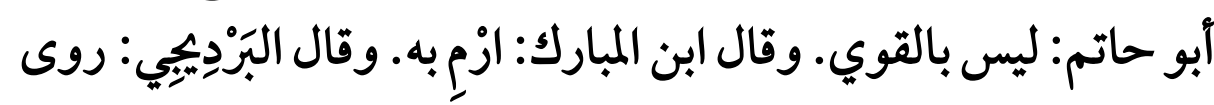
عن بجاهد، وفي سماعه منه نظر، وليس هو بالقوي. وقال النسائي: ليس

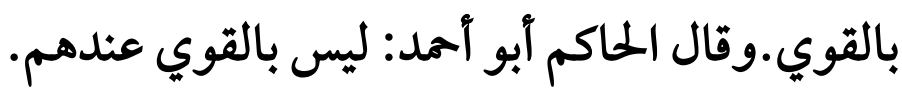

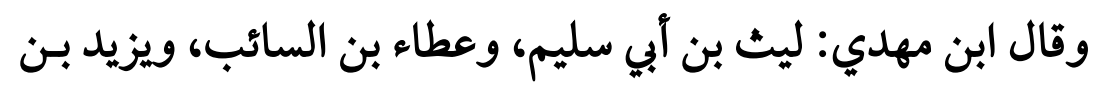

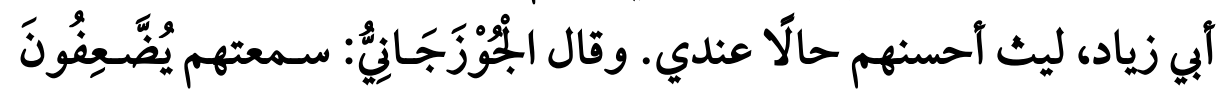

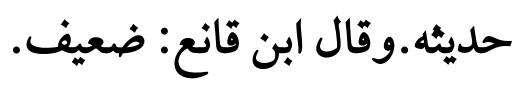

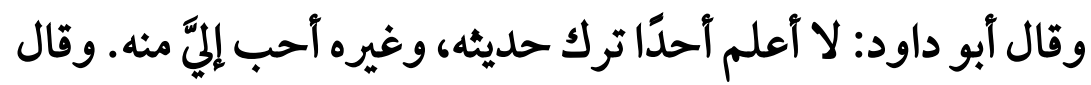

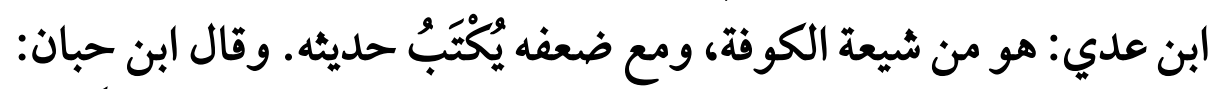

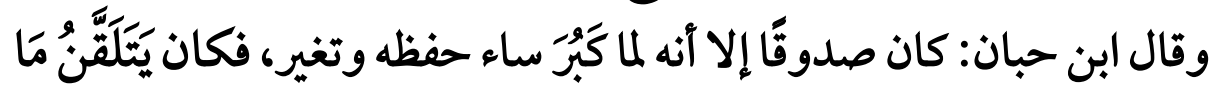
لُقِّنَ، فوقع المناكير في حديثه من تلقين غيره إياه وإجابته صئه

|) رَفَّاعَا: بفتح الراء وتشديد الفاء أي: كان يرفع الأحاديث الموقوفه كثيرَا؛ قال

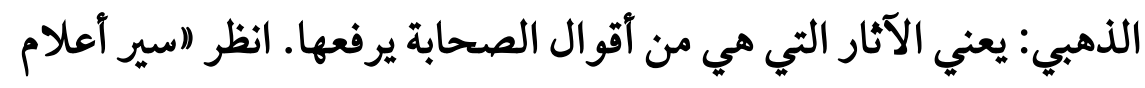

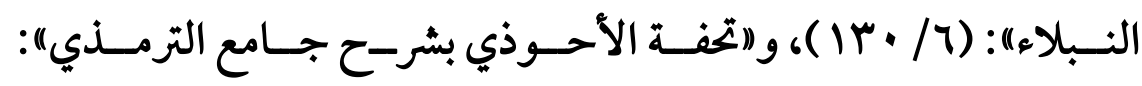




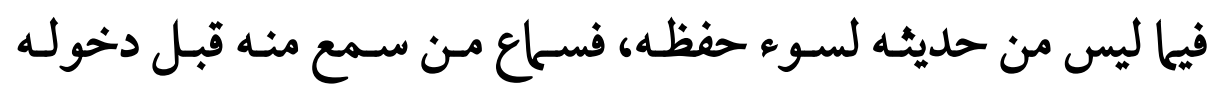

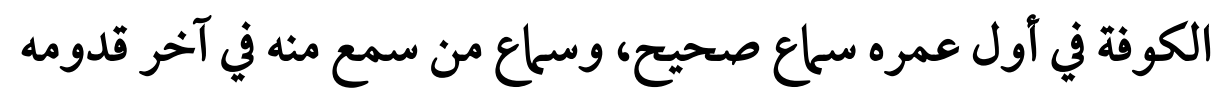
الكوفة بعد تغير حفظه وتلقنه ما يلقن سلحاع ليس بشيء. وقال يعقوب بن سفيان: ويزيد وإن كانوا يتكلمون فيه لتغيره،

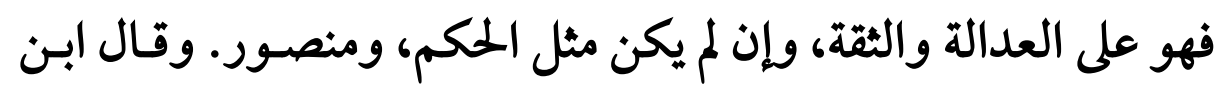

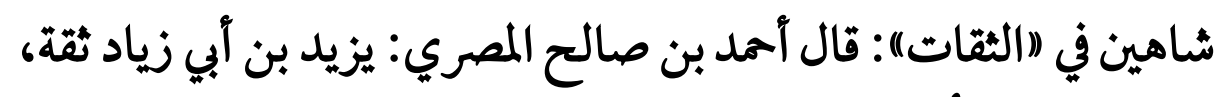

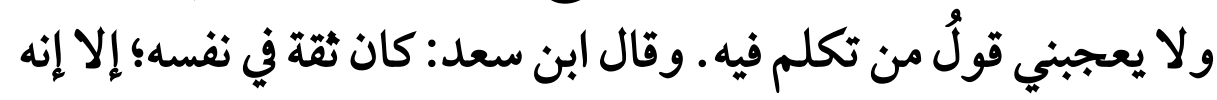

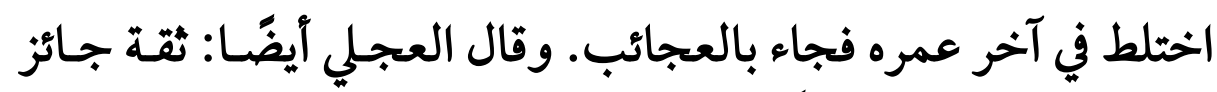
الحديث، وكان بآخره يُلَقَّن.

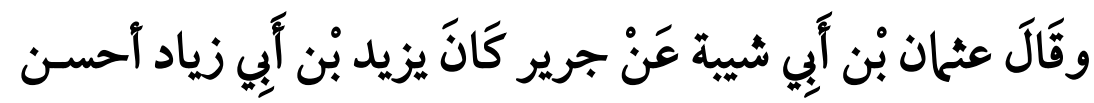
حفظا من عطاء بْن السائب.

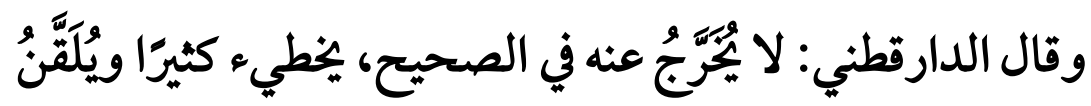

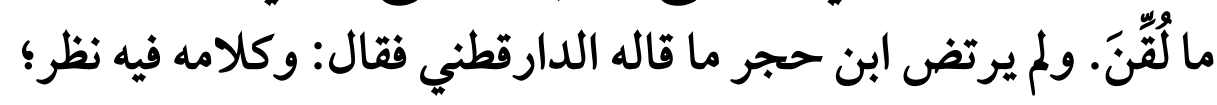

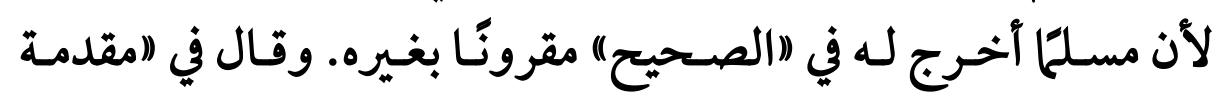

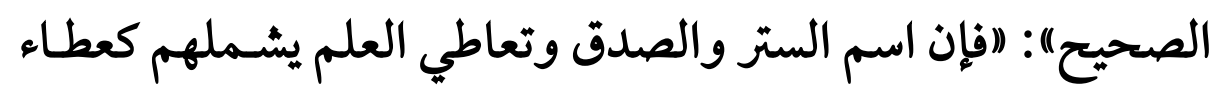

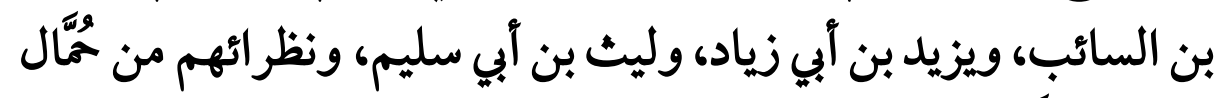

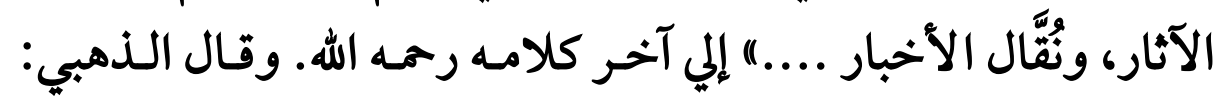

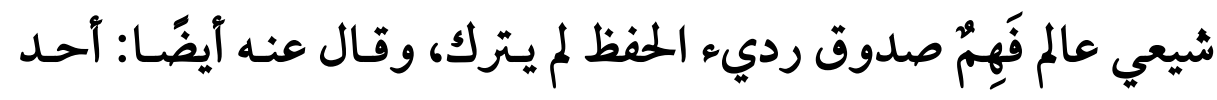


علماء الكوفة المشاهير علي سوء حفظه. وقال ابن حجر : ضسعيف كَبهر

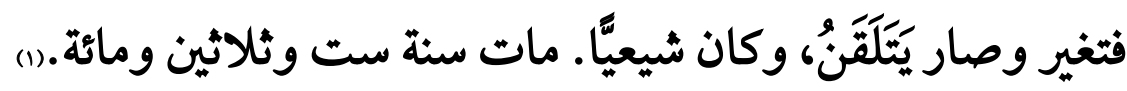

\section{المناقشة والترجيح}

بعد استعراض ومراجعة أقوال النقاد في يزيد بن أبي زياد، يظهر الثراد

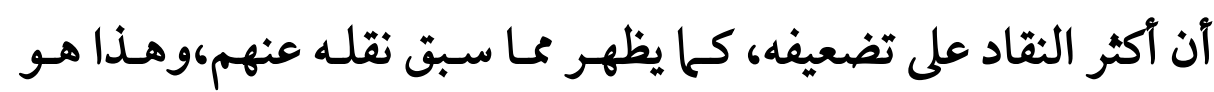

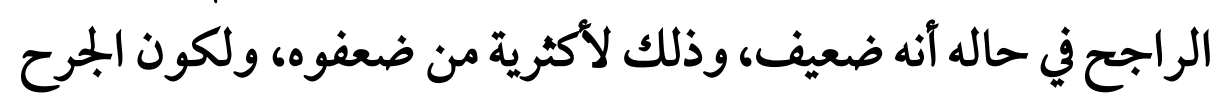
مفسر بتغيره وقبوله التلقين.

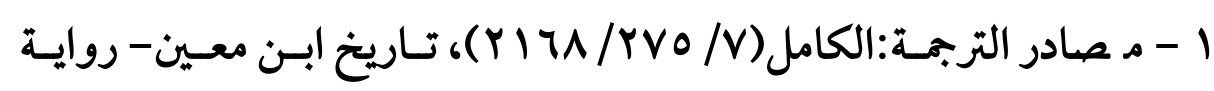

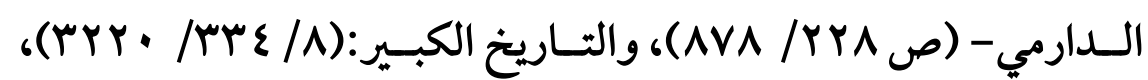

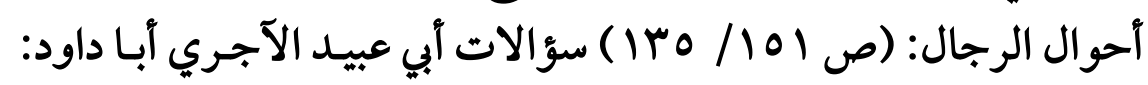

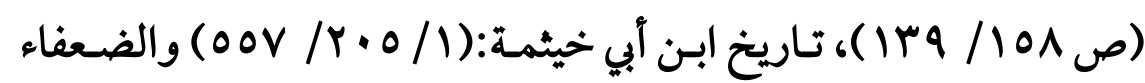

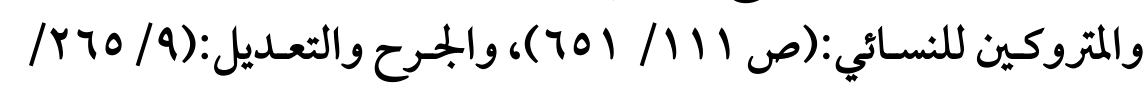

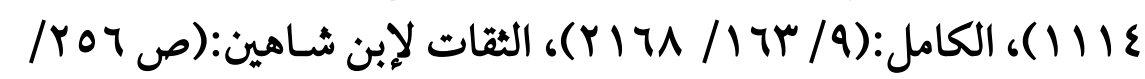

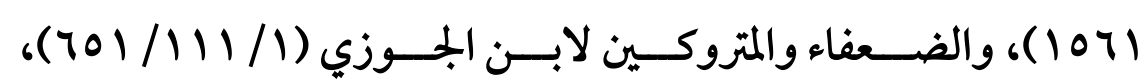

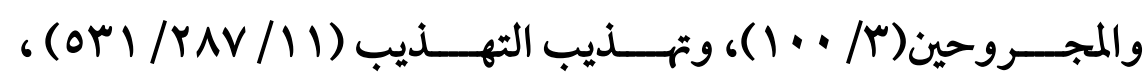

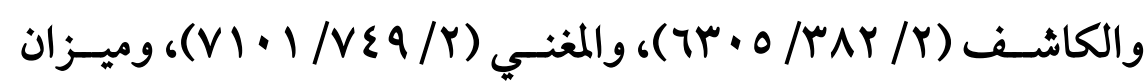

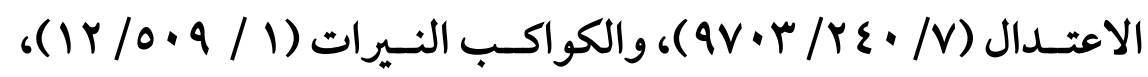

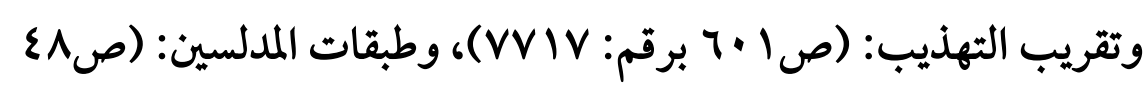

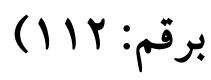


غير آن عبارة الإمام العجلي هنا لا تفيد تضعيفه، وإنها تدل على

أنه في مرتبة حسن الحديث ، وقرائن ذلك:

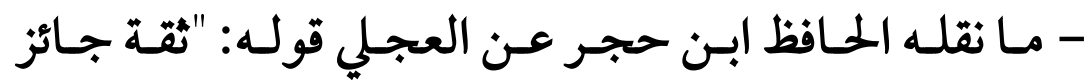

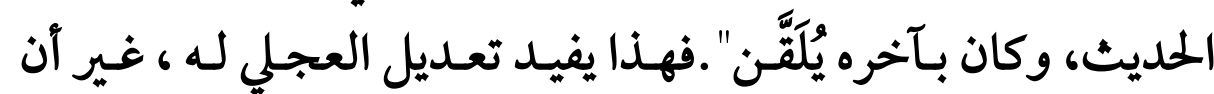

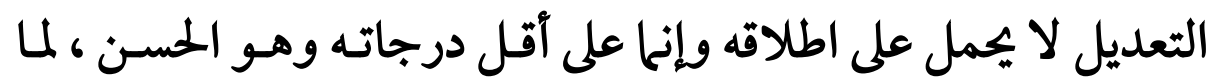

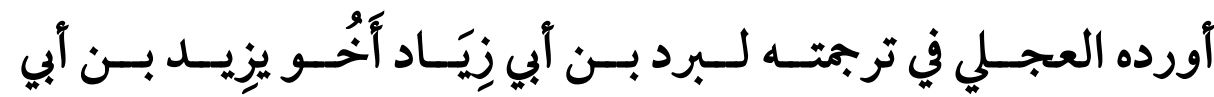

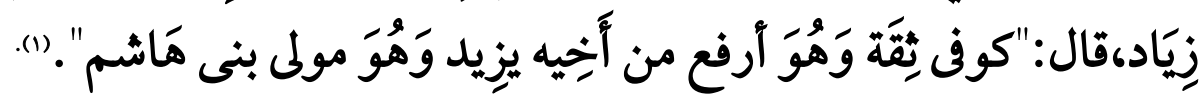

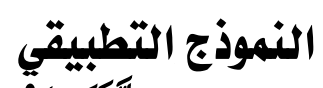

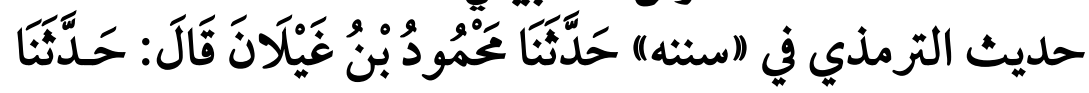

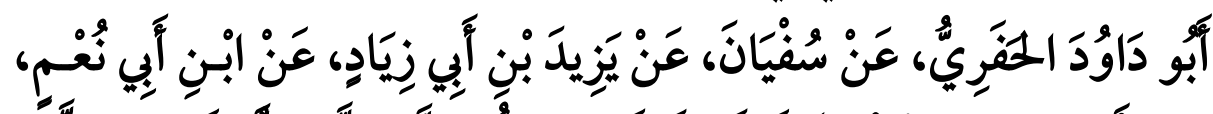

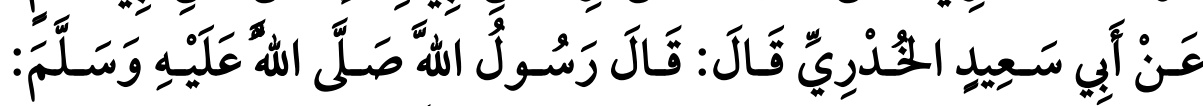

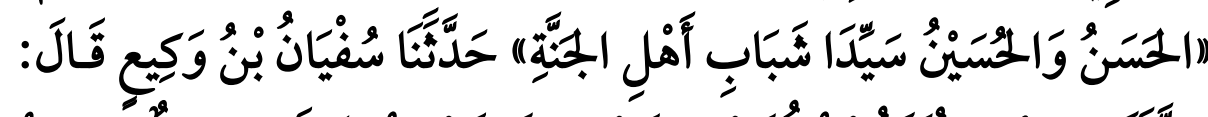

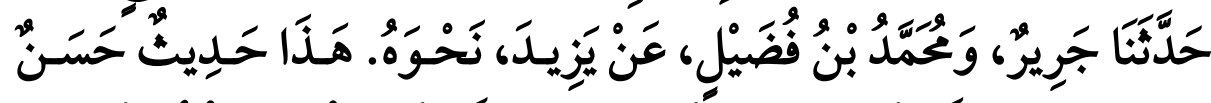

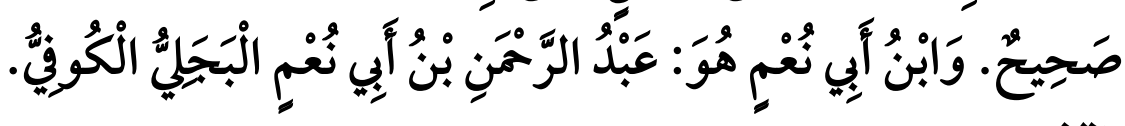

آخرجه الترمذي في "جامعه" أبواب المناقب عن رسول الله صلى وملى

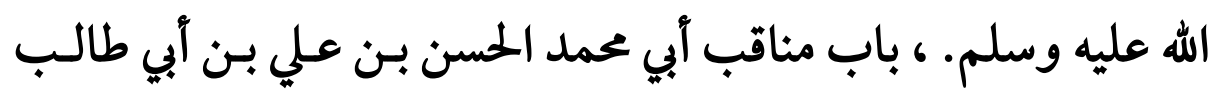

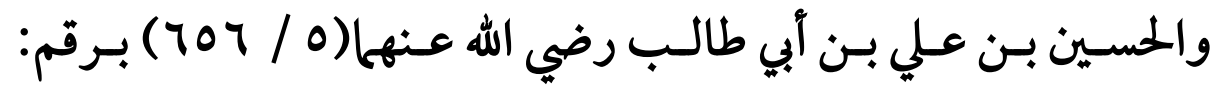

$$
1 \text { - معرفة الثقات (1/ص ص^/ ج qهו) }
$$


(9v)

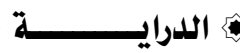

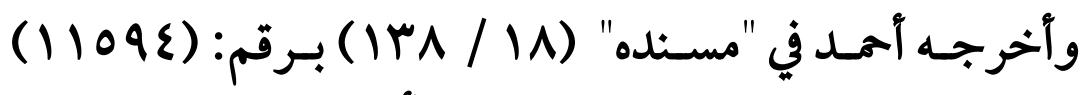

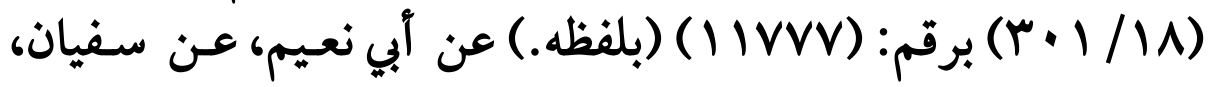

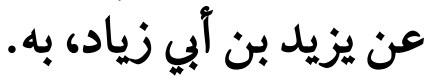

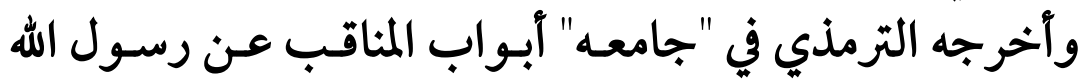

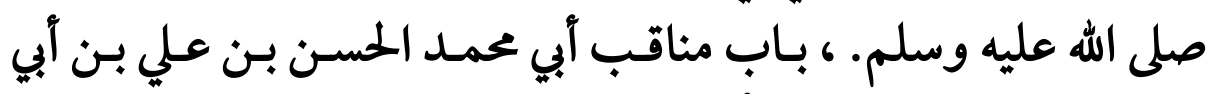

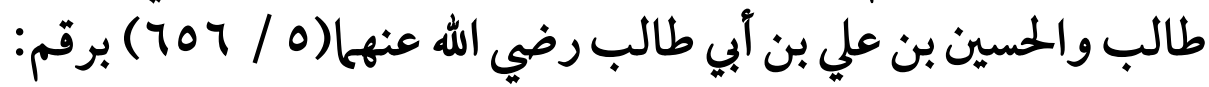

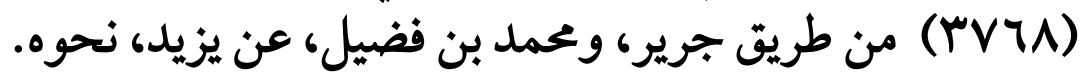

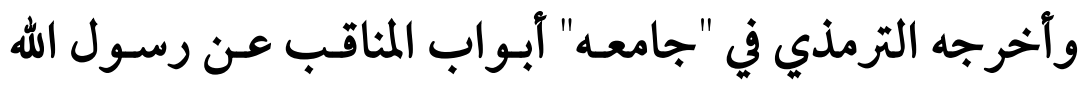

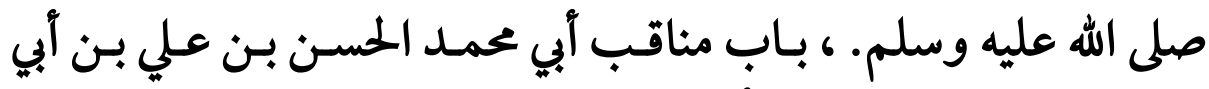

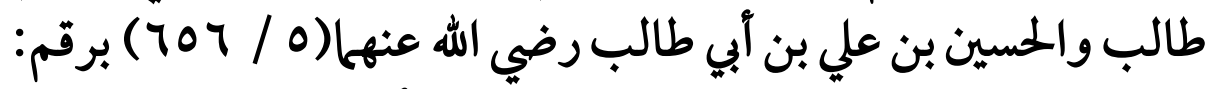

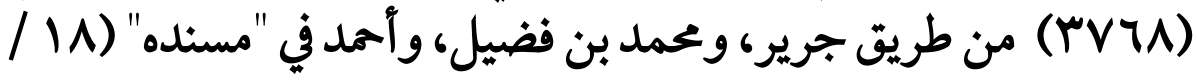

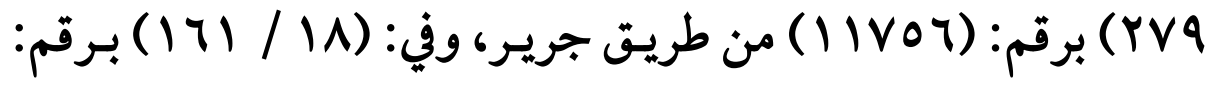

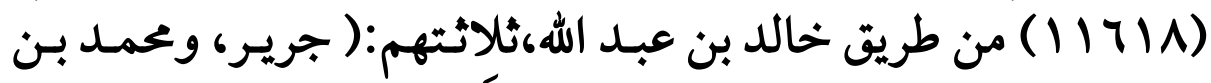

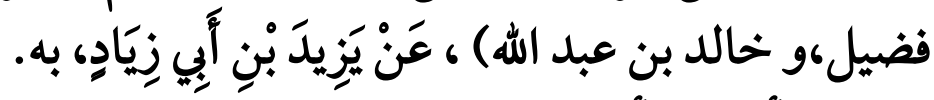

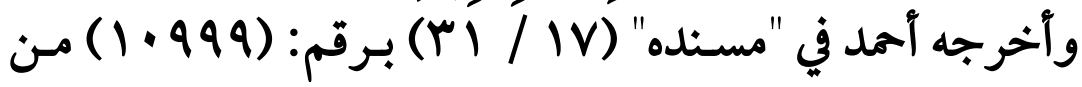

طريق يزيد بن مردانبة، قال: حدثنا ابن أبي نعم،به.

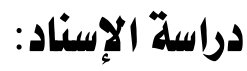

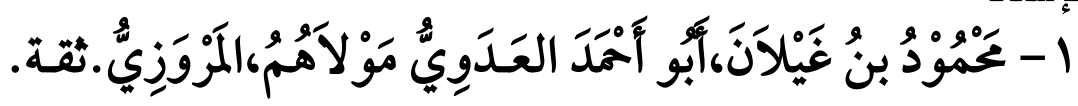

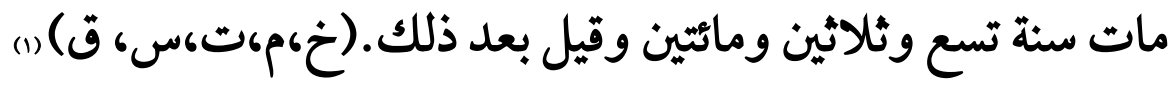

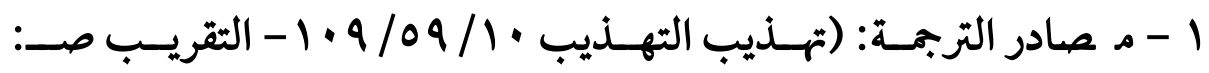

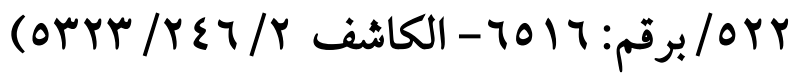


$(9 \wedge)$

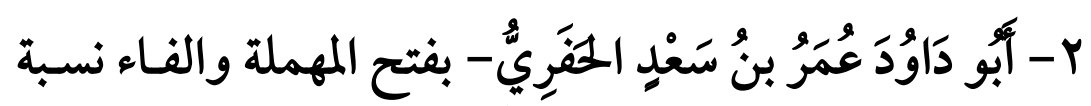

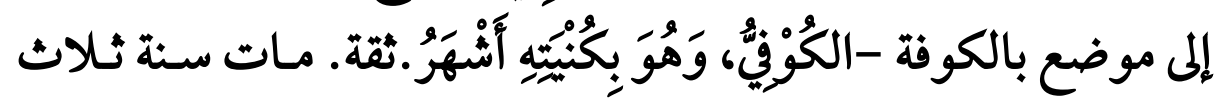

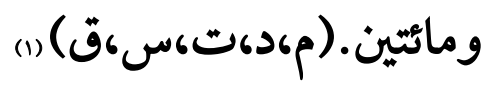

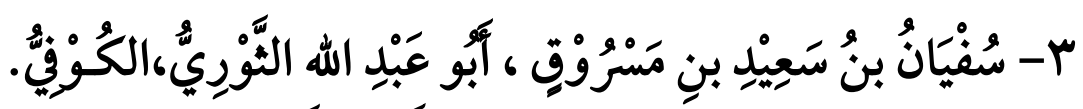

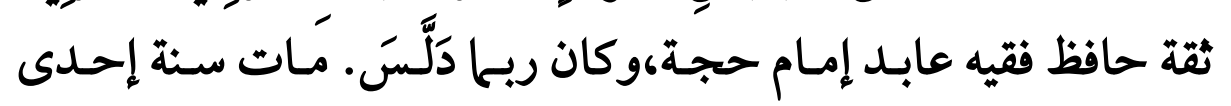

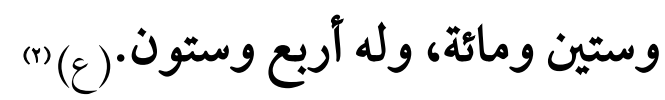

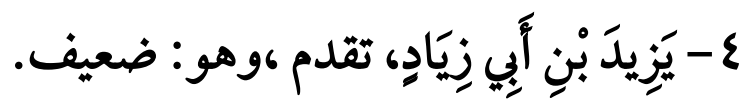

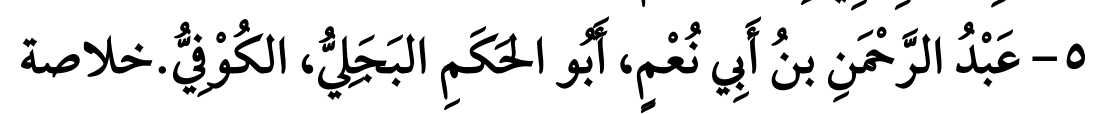

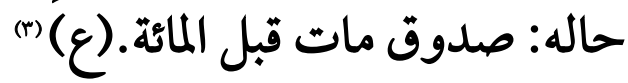

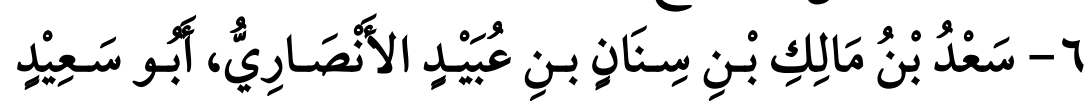

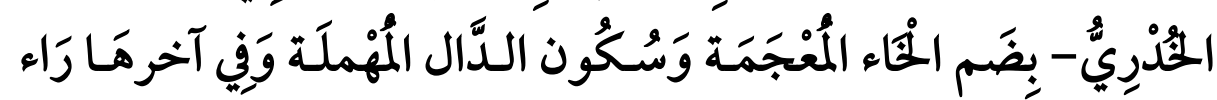

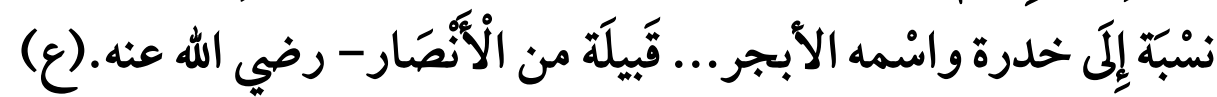

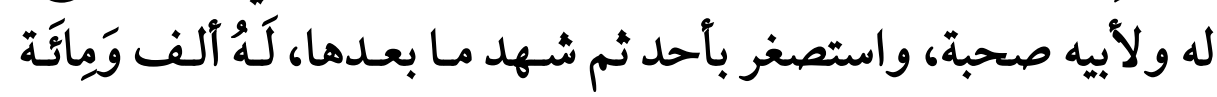

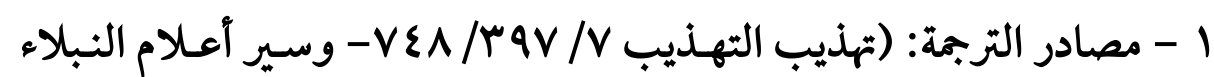

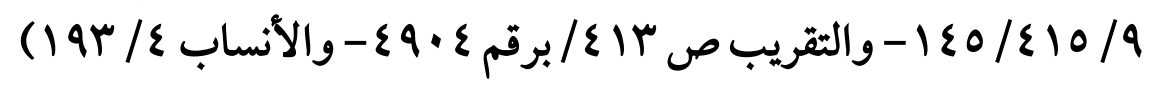

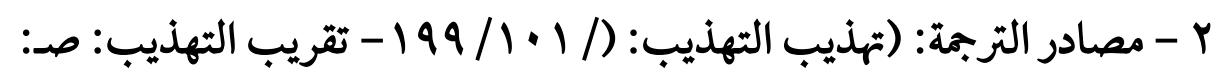

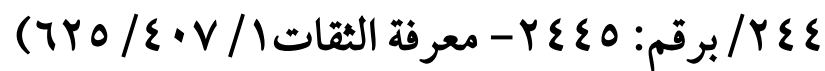

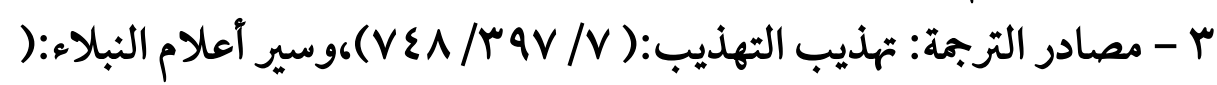

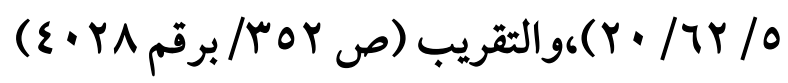




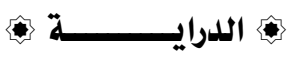

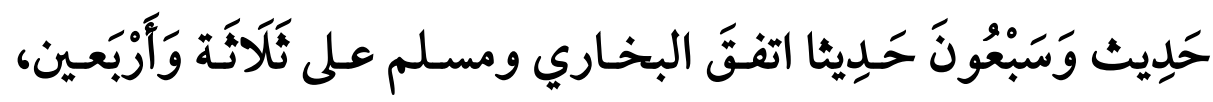

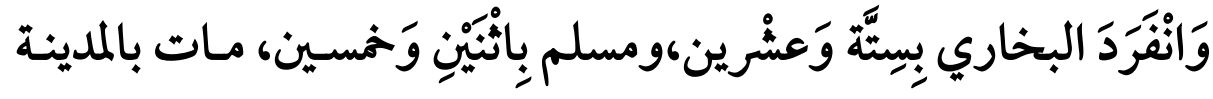

سنة ثلاث. (1)

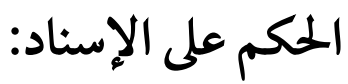

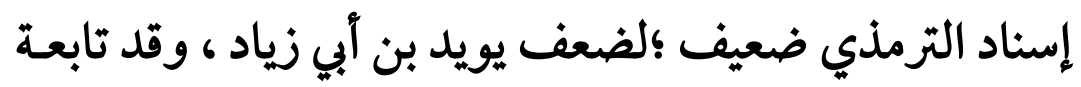

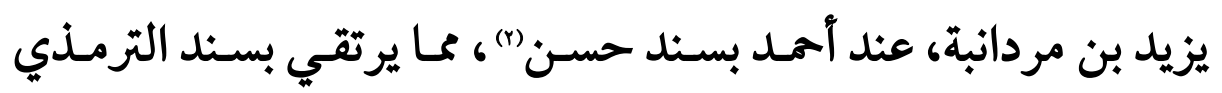

للحسن لغيره.

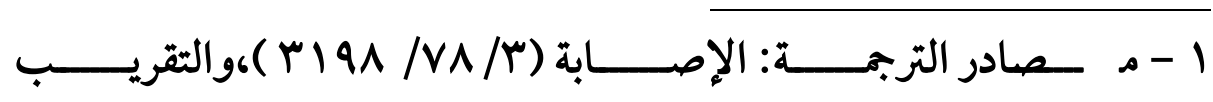

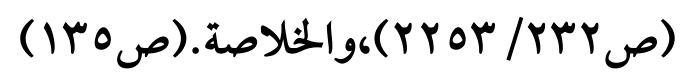

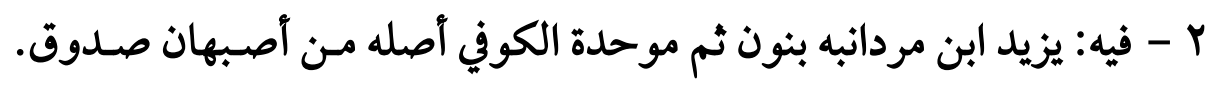

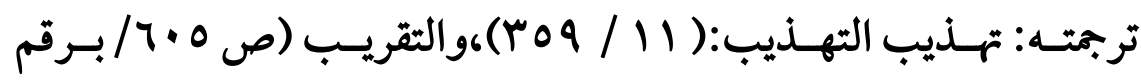

(VVV 


\section{الخاتثة والنتائج والتوصيات}

بعد هذه الجمولة العلمية الماتعة التي قمت فيها بترجمة موجزة التوميات للإمام

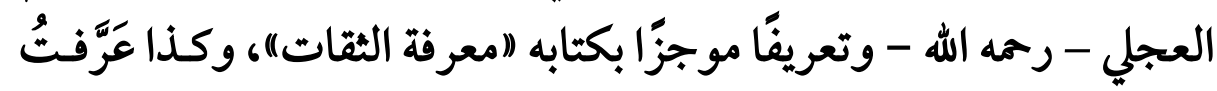

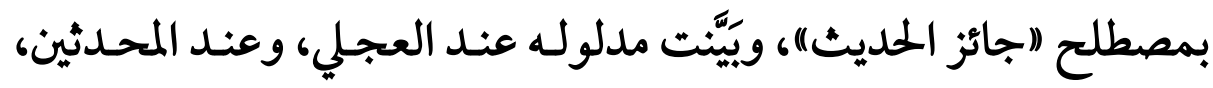

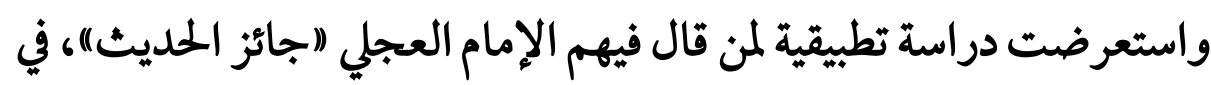

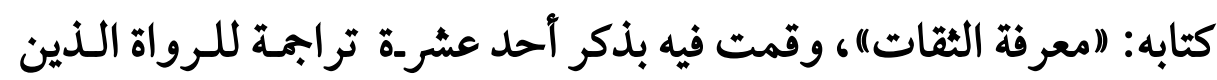

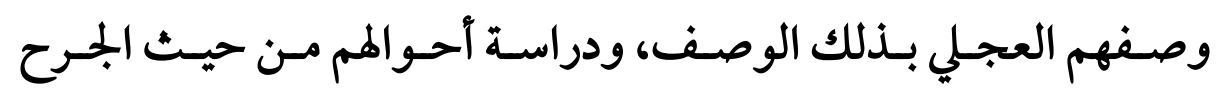

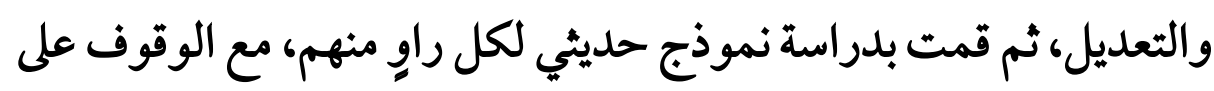
أحكام العلم)ء على هذه الأحاديث.

وأما عز أهم النتائج التي توصلت إليها من خلال بحثي هذا الادي فهي على النحو الآتي: ا ـ أن علم الجرح والتعديل من آجل العلوم الإسـلامية عامة،

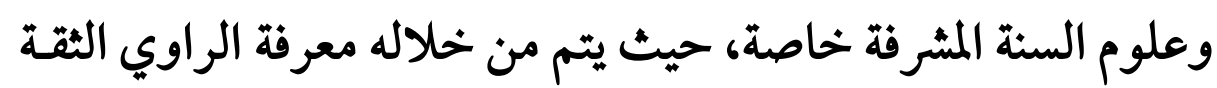

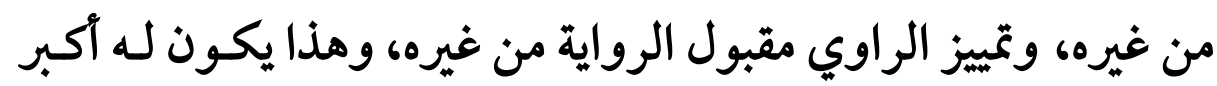

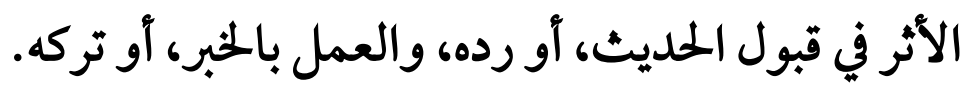

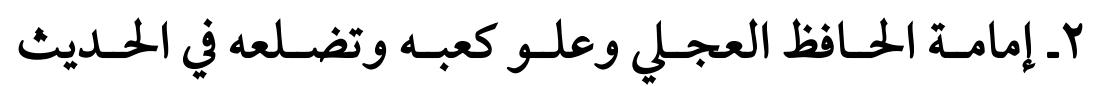

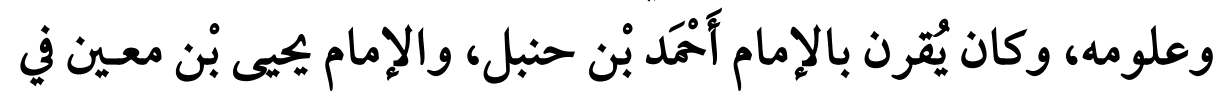
حفظه وإتقانه، وتمكنه في صنعة العلل ومعرفة الرجال. r- الاختلاف في اسم كتاب العجلي بين العلماء له آثر في تحديد

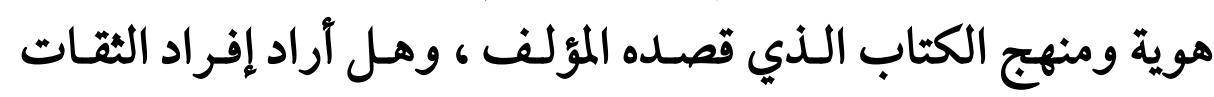


خاصة، أو هو بجرد سؤالات ،أو هل تصح تسميثه بـ"معرفة الثقات من

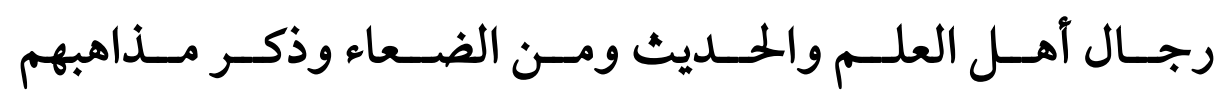

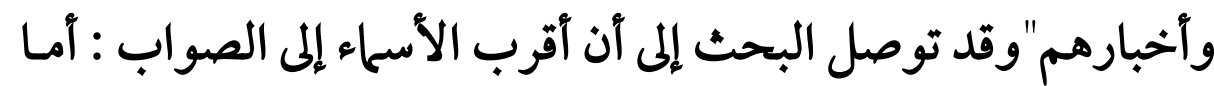

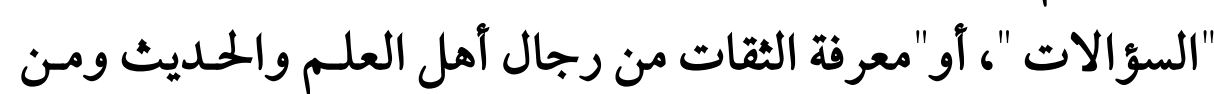

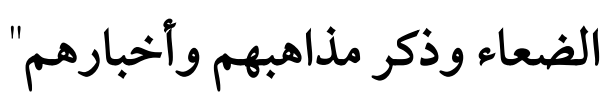

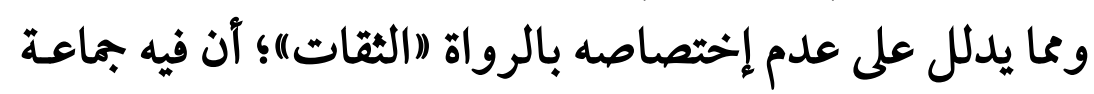

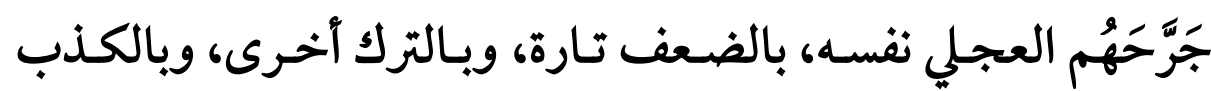
أحيانَا، وبالتهمة بالكذب في أحايين آخر، وبالزندقة أيضًا.

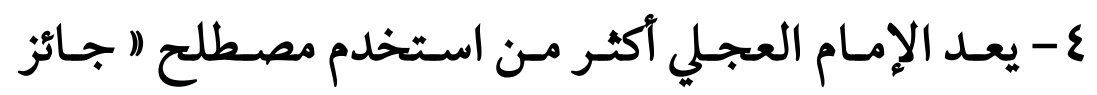

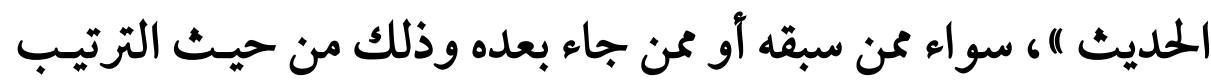

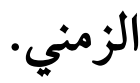
ـ استعمل الإمام العجلي مصطلح "جائز الحديث ) في رتبة من

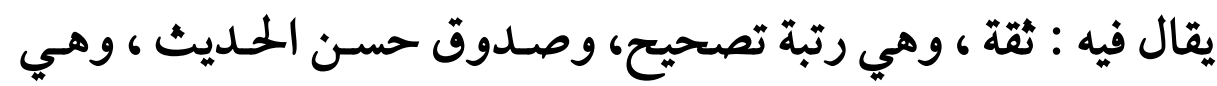

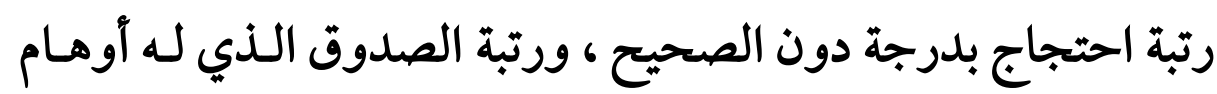
معدودة، ورتبة المعتبر به. 7- بلغ عدد الرواة الذين أطلق عليهم العجلي : (جائز الحديث ) )

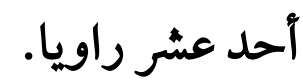


V- من خلال القرائن المباشرة وغير المباشرة تبين موافقة الإمام

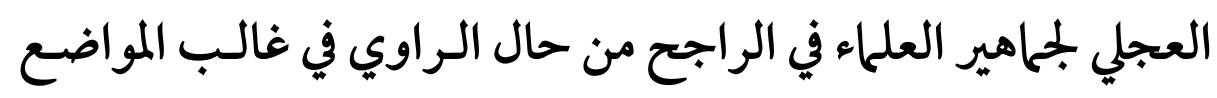
فيا خالفهم في موضعين.

وغير ذلك مـن التـائج التي يمكـن التوصل إليها مـن خـلال

فأوصي باجراء دراسات أنوات أخرى مقارنة لدراسة هذا المصطلح

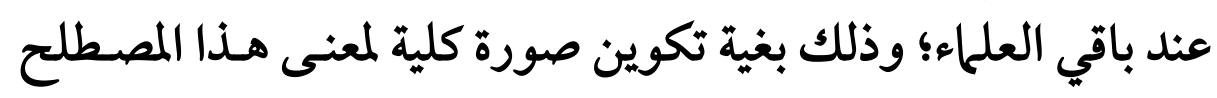

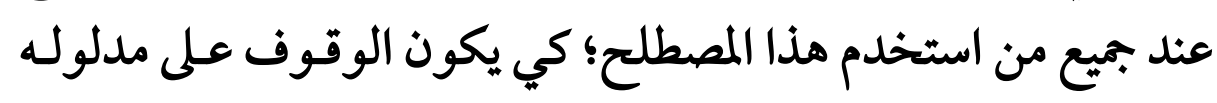
مبنيا على إستقراء تام.

والحمد لله الذي بنعمته تتم الصالحات.

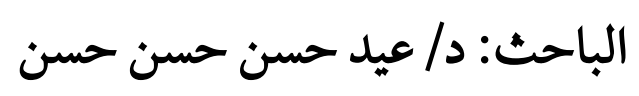

مدرس الحديث وعلومه بكلية أصول الدين بالقاهرة 


\section{(فهرس المصادر والمراجع)}

الإصابة في تمييز الصحابة. المؤلف: أحمد بن علي بـن حجر آبـو

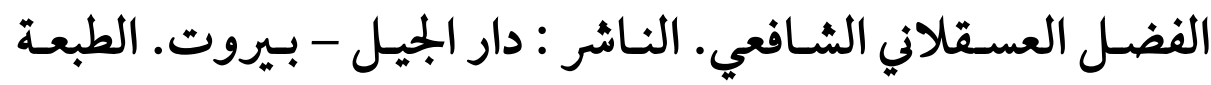
الأولى، Y | ا ا هـ. تحقيق : علي محمد البجاوي.

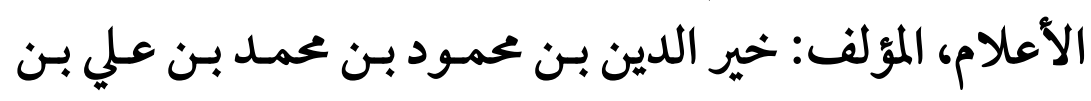

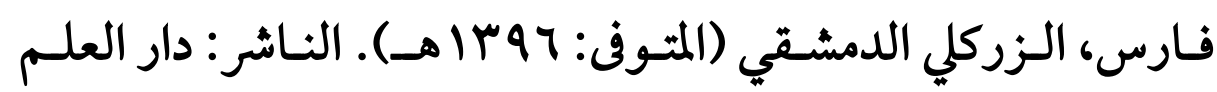

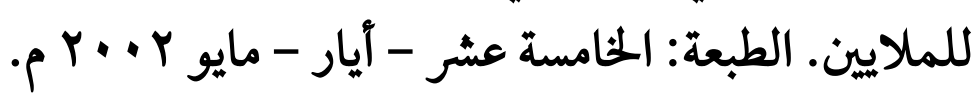
الاقتراح في بيان الاصطلاح، المؤلف: تقي الدين أبو الفتح محمد بن علي بن وهب بن مطيع القشيري، المعروف بابن دقيق العيد (المتوفى:

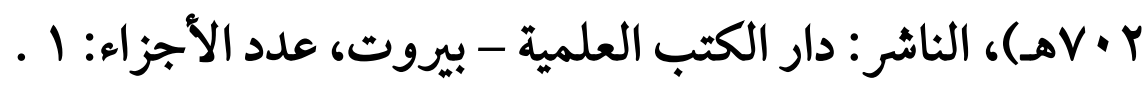

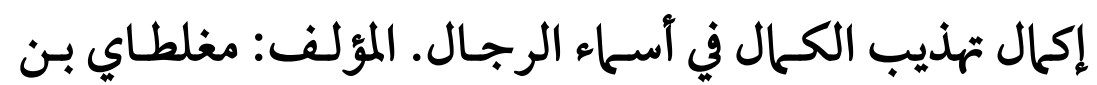

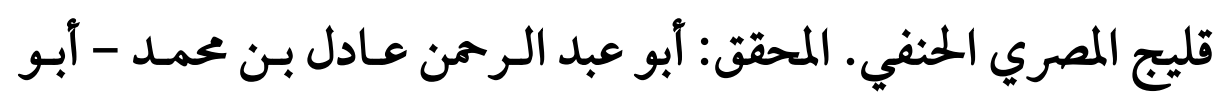

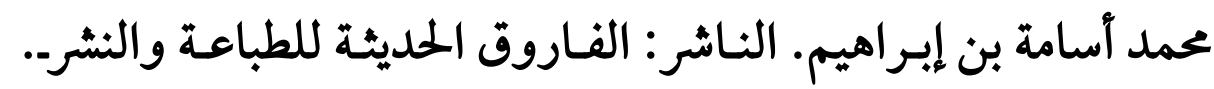

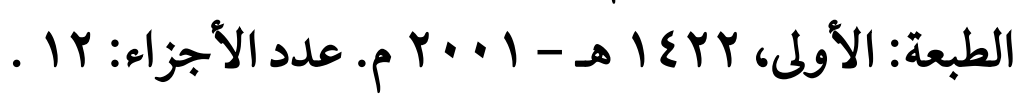
الأنساب. المؤلف: أبو سعد السمعاني. المحقق: عبد الرحمن بن

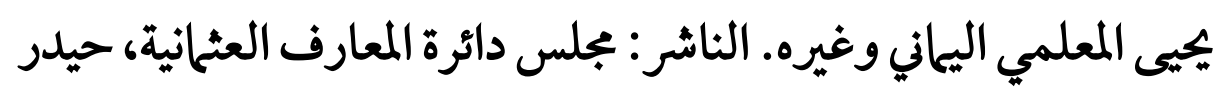

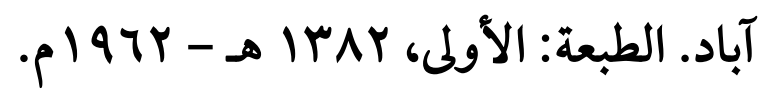
بحث حول توثيق العجلي للدكتور حاتم بن عارف العوني. 


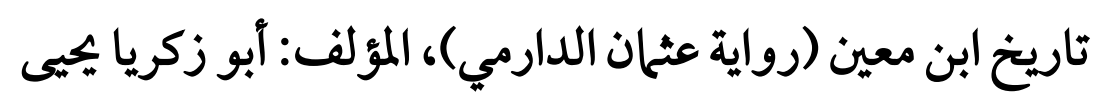

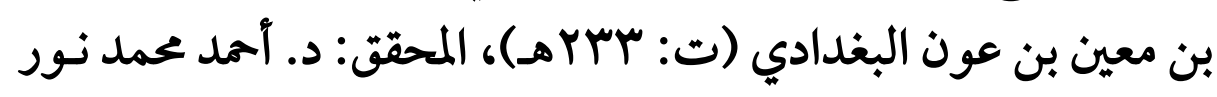
سيف، الناشر: دار المأمون للتراث - دمشق.

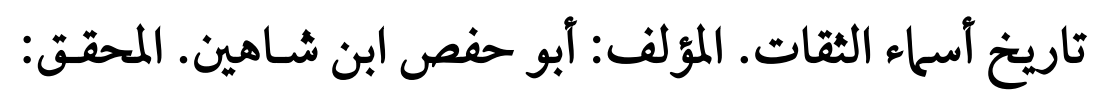
صبحي السامرائي. الناشر: الدار السلفية - الكويت. الطبعة: الأولى المانى .

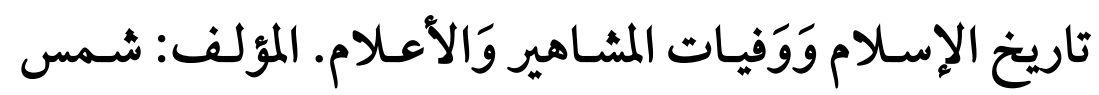

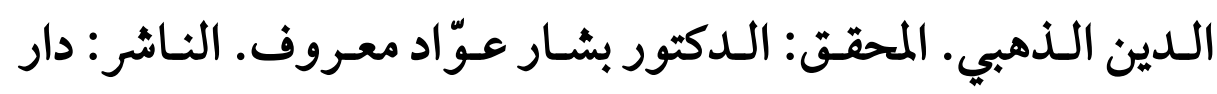

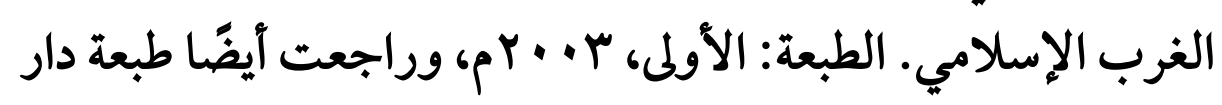

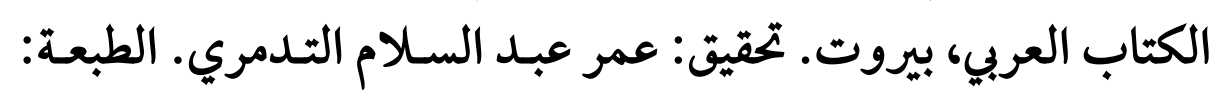

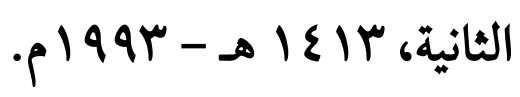

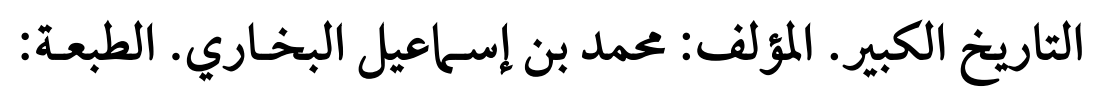

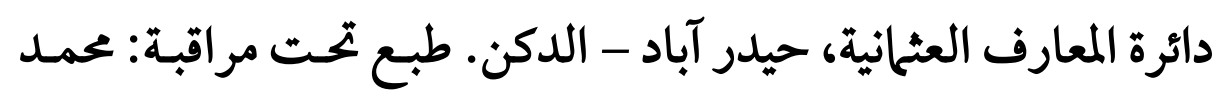

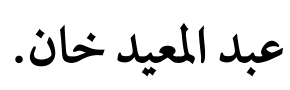

تاريخ بغـداد. المؤلف: أبو بكر الخطيب البغدادي. المحققق:

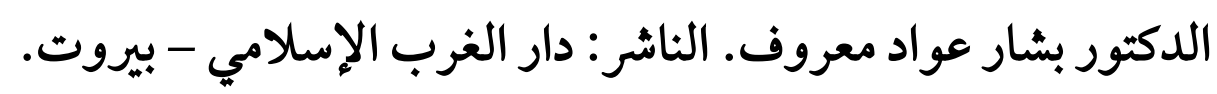

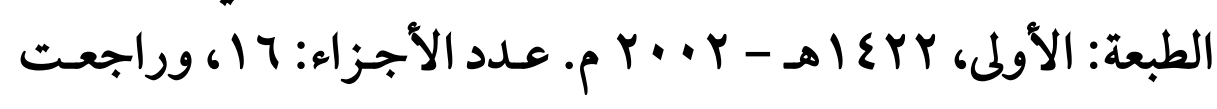

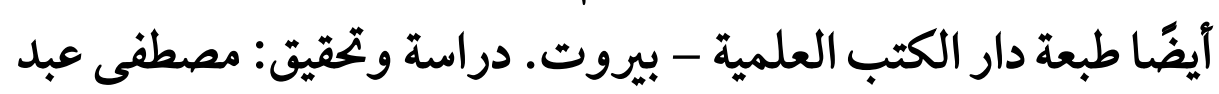
القادر عطا. الطبعة: الأولى، VIV I أهـ. 
تحرير تقريب التهذيب. المؤلف: د: بشار عواد معروف. الشيخ:

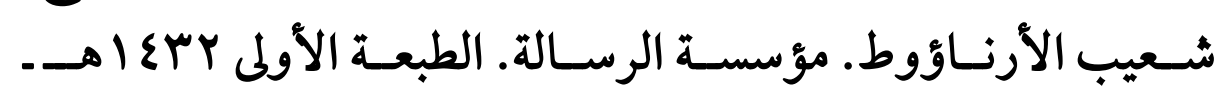
p $r \cdot 11$

تحفة التحصيل في ذكر رواة المراسيل، المؤلف: أحمـد بـن عبـد

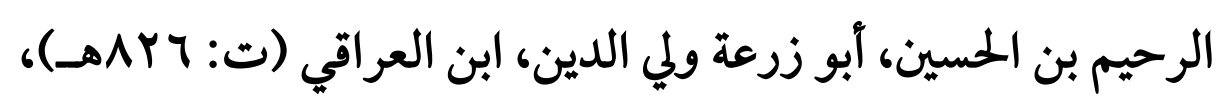

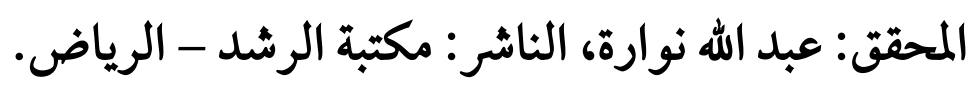

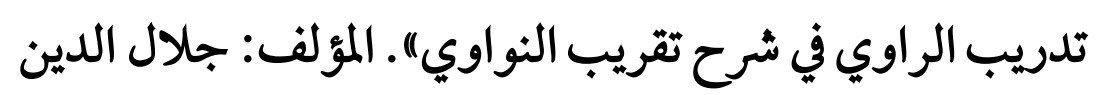

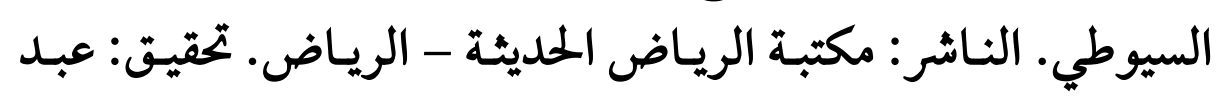

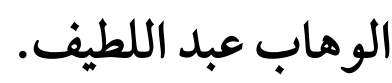
تذكرة الحفاظ. المؤلف: شمس الدين الذهبي (المتوفى: ^ع Vهـ).

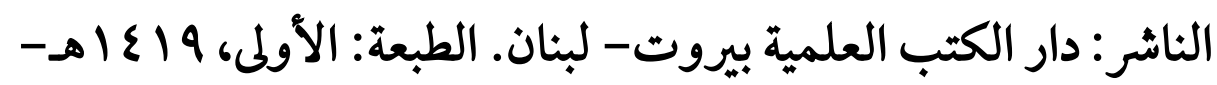

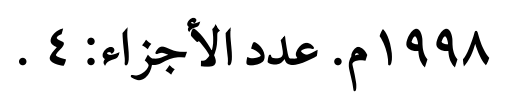

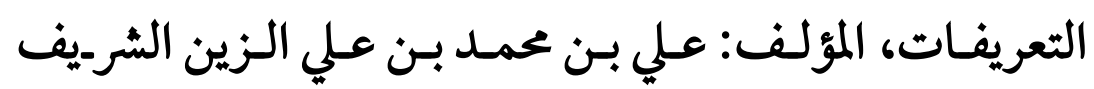

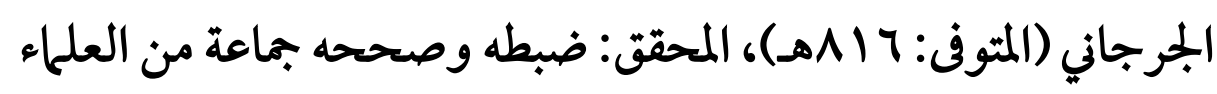

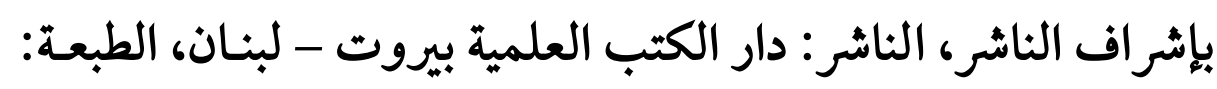

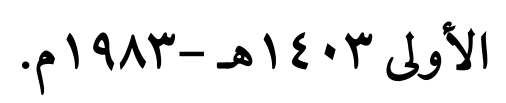

تقريب التهذيب. المؤلف: ابن حجر العسقلاني. المحقق: محمـد

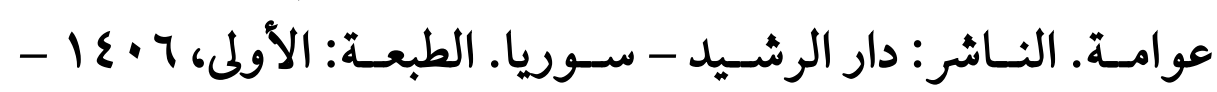

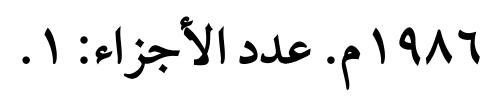


تنزيه الشريعة المرفوعة عن الأخبار الثـنيعة الموضسوعةالمؤلف:

نور الدين، علي بن محمد بـن علي بـن عبـد الرحمن ابـن عـراق الكنـاني

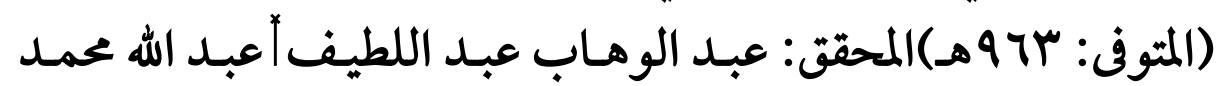
الصديق الغماري الناشر: دار الكتب العلمية - بيروت. تهذيب التهذيب. المؤلف: ابن حجر العسقلاني. الناشر : مطبعة

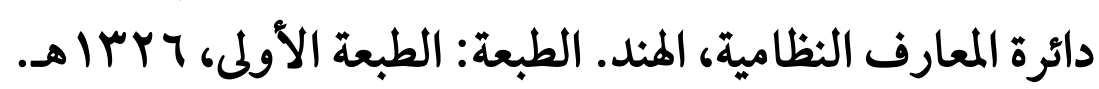
تهذيب الكمال في أسهاء الرجـال. المؤلف: أبـو الحجـاج المزي.

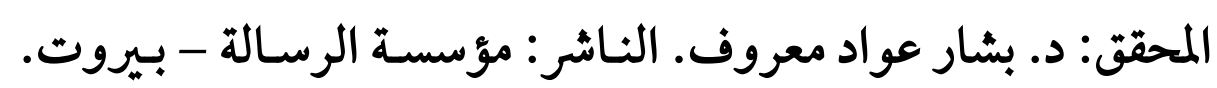

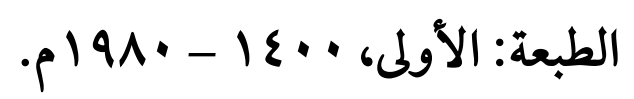

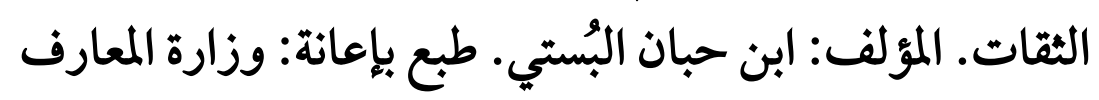
للحكومة العالية المندية. تحت مراقبة: الدكتور محمد عبد المعيد خدان المبان

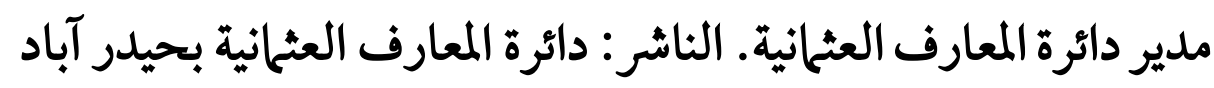

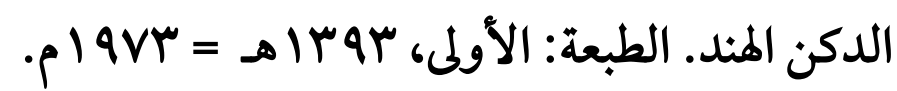

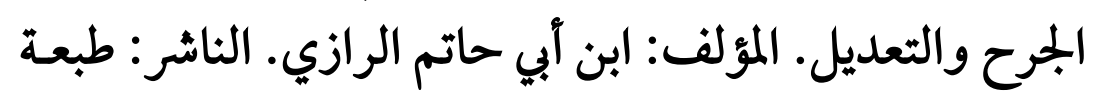

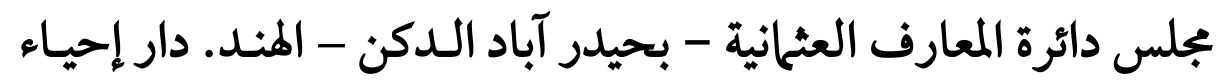

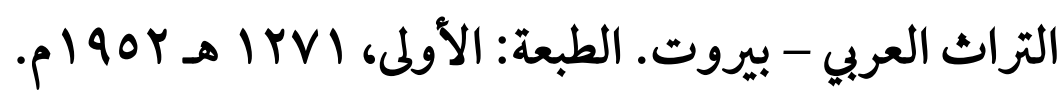

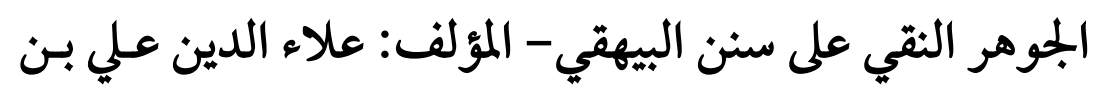

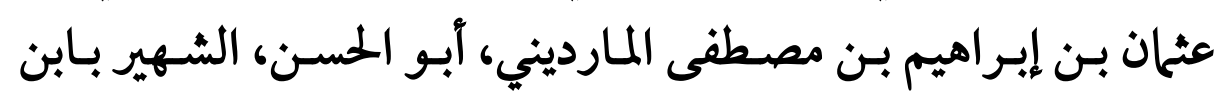

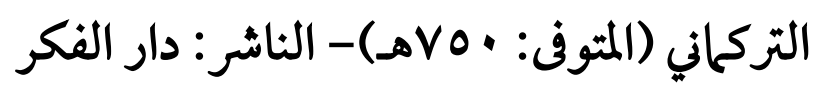


خلاصة تذهيب تهذيب الكمال في أسهاء الرجال. المؤلف: أحمد

بن عبد الله بن أبي الخير الخزرجي اليمني. المحقق: عبد الفتاح أبو غدة.

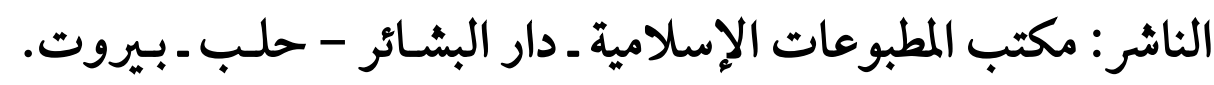

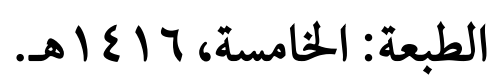

ذكر من يعتمد قوله في الجرح والتعديل (مطبوع ضـمن كتاب

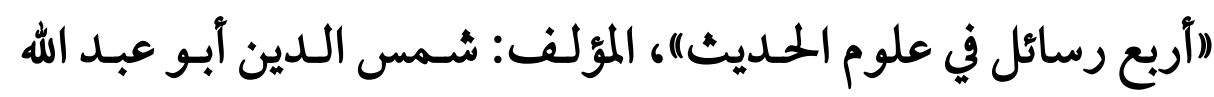

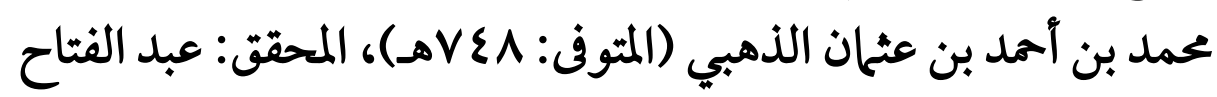

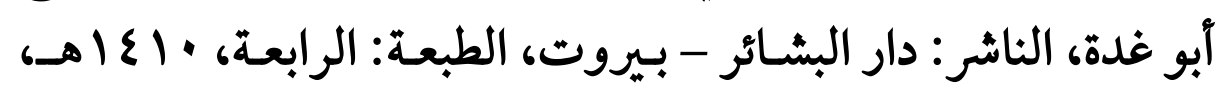
p 199. الرواة الثقات المتكلم فيهم بـا لا يوجب ردهم. المؤلف: الإمام

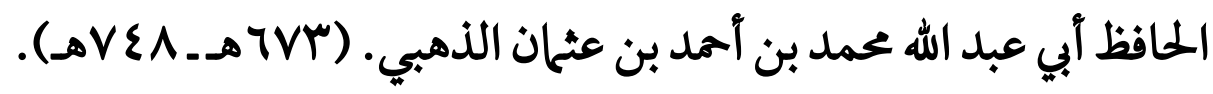
تحقيق: محمد إبـراهيم الموصلي. النـاشر: دار البشـائر الإسـلامية. سـنة

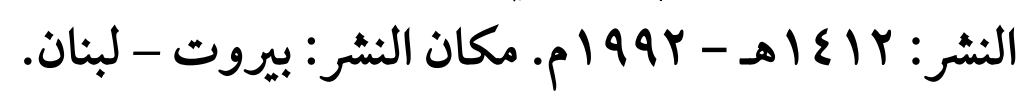
سنن ابن ماجه، تأليف: محمد بن يزيد أبو عبداله القزويني، دار النشر: دار الفكر - بيروت. تحقيق: محمد فؤاد عبد الباقي.

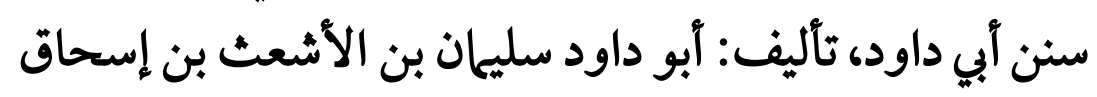

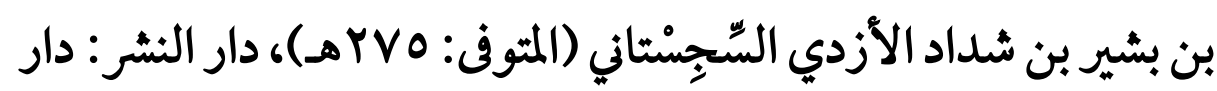
الفكر، تحقيق: محمد محيي الدين عبد الحميد. 
سنن البيهقي الكبرى، تـأليف: أمــد بـن الحسبين بـن علي بـن

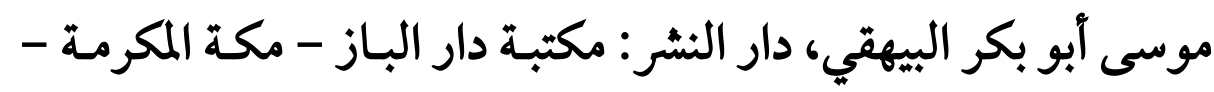

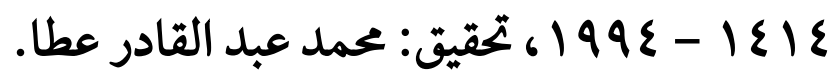

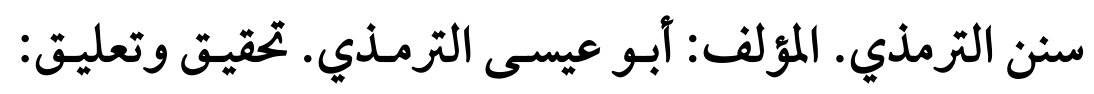

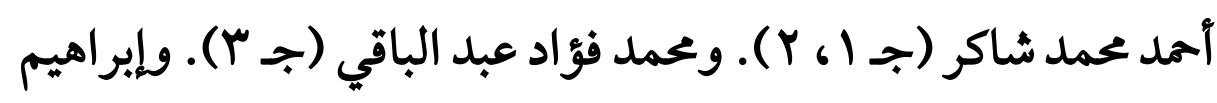

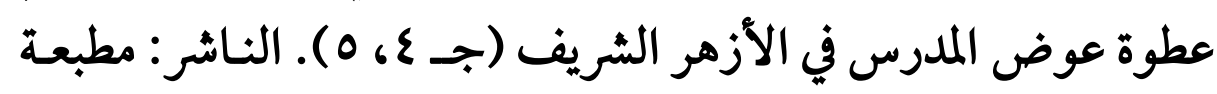

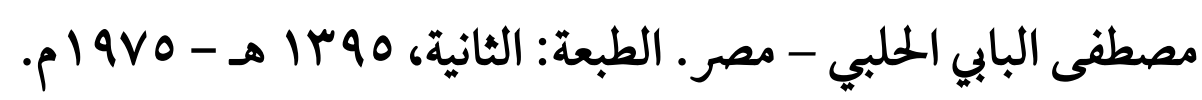

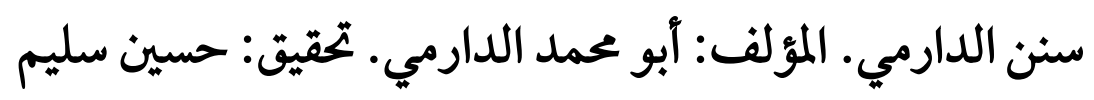

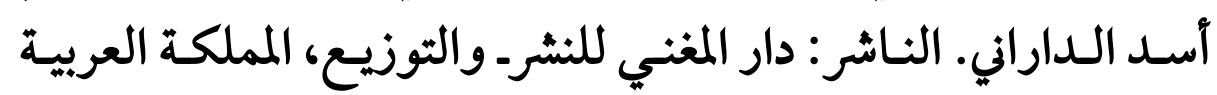

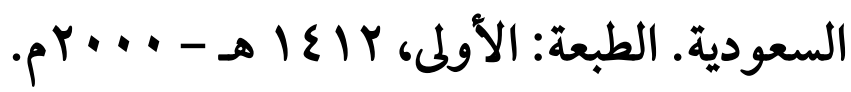

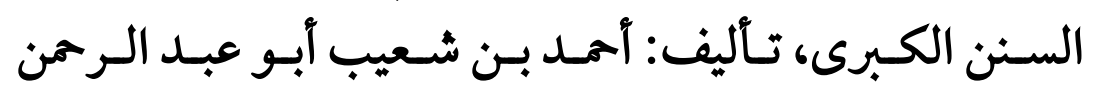

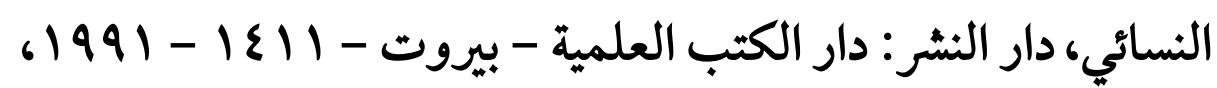

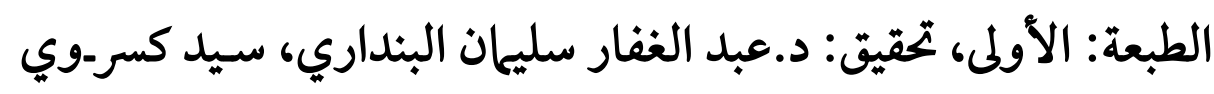

سير أعلام النبلاء. المؤلف : شـمس الدين الذهبي. المحقـق :

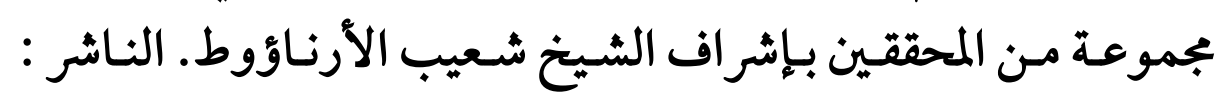

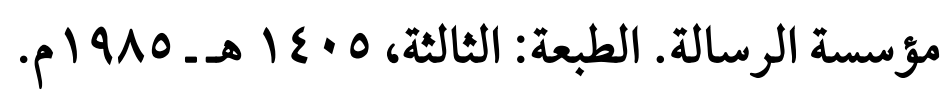
شذرات الذهب في آخبار من ذهب. المؤلف: ابن العجاد الحنبلي.

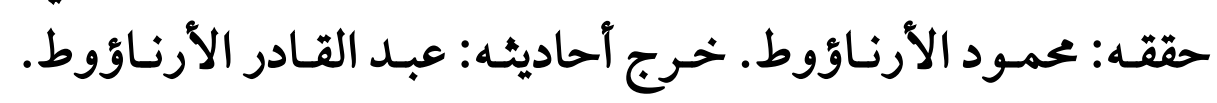


الناشر: دار ابن كثير، دمشق - بيروت. الطبعة: الأولى، 7 + ع ا هـ - 1917

شرح النووي على صحيح مسلم. المؤلف: ميي الدين النووي.

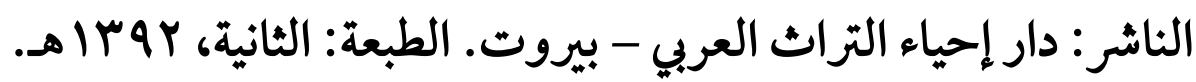
شرح علل الترمذي، المؤلف: زين الدين عبد الرحن بن أحمد بن رجب بن الحسن، السَلامي، البغدادي، ثم الدمشقي، الحنبلي (المتوفى: VA VO)، المحقق: الدكتور همام عبد الرحيم سعيد، الناشر : مكتبة المنار

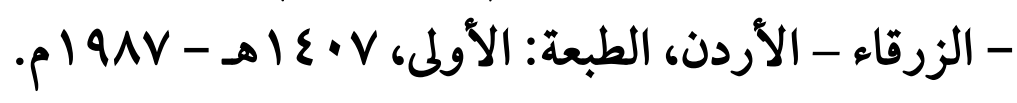
صحيح ابن حبان بترتيب ابن بلبان. المؤلف: ابن حبان البُستي

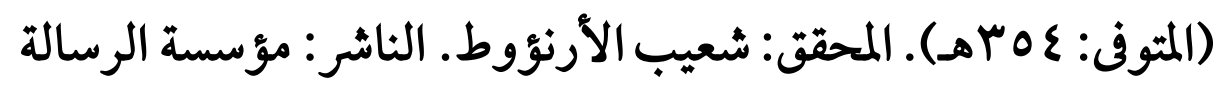

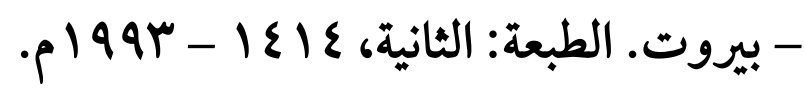
صحيح البخاري. المؤلف: محمد بن إسهاعيل البخاري. المحقق:

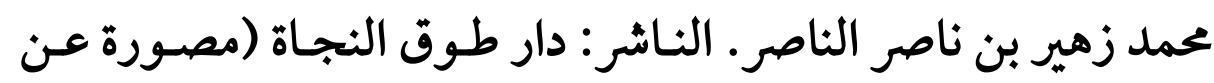

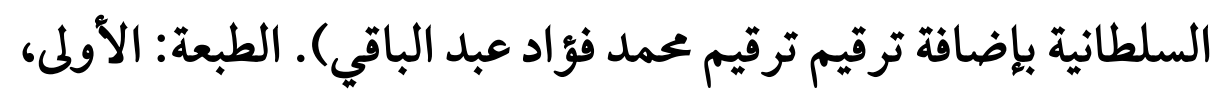
أه

صحيح مسلم. المؤلف: مسلم بن الحجاج أبو الحسن القشيري

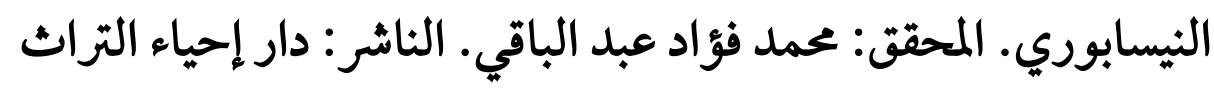

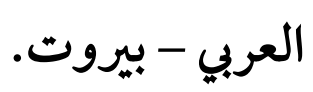


الضعفاء الكبير. المؤلف: أبو جعفر العقيلي المكي. المحقق: عبد

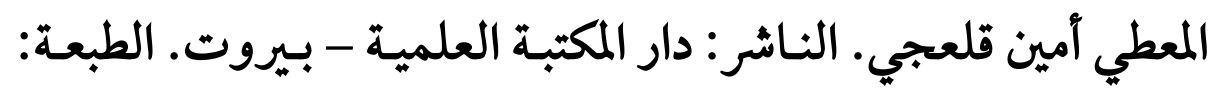

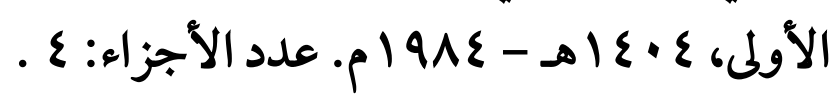

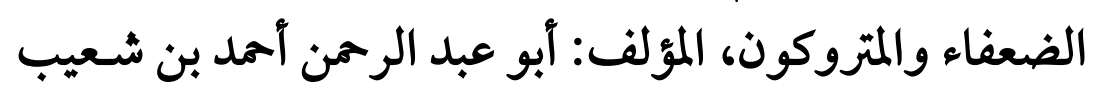

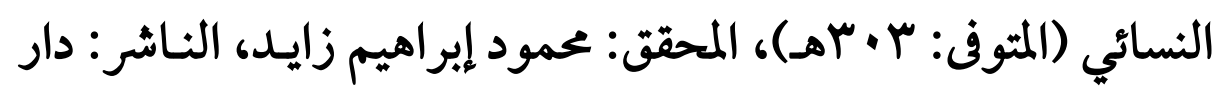
الوعي - حلب، الطبعة: الأولى، 97 با هـ. طبقات الحفاظ، المؤلف: عبد الرحمن بن أبي بكر، جلال الدول الدين

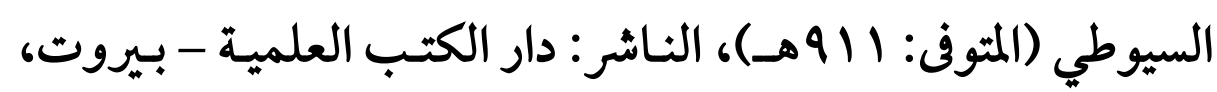

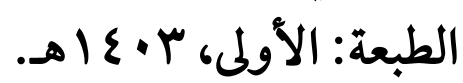

طبقات المدلسين. المؤلف: ابـن حجر العسـلاني. المحقق: د. د.

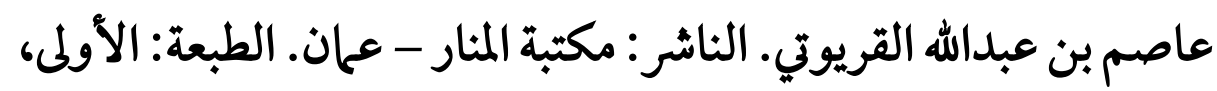

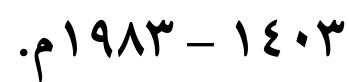

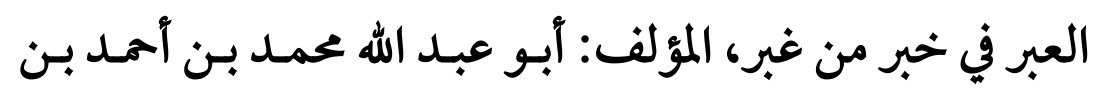

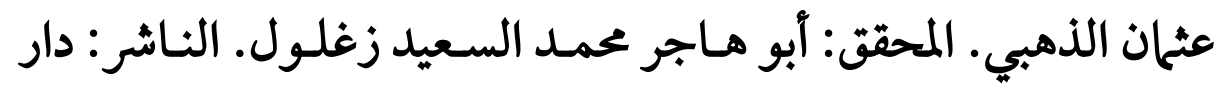
الكتب العلمية - بيروت. علوم الحديث، ويسمى بـ "(مقدمة ابن الصلاح)" ـ المؤلف: عثهان بن عبد الرحمن، أبوعمرو، تقي الدين المعروف بابن الصلاح (المتوفى:

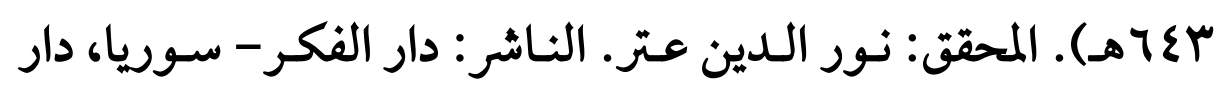

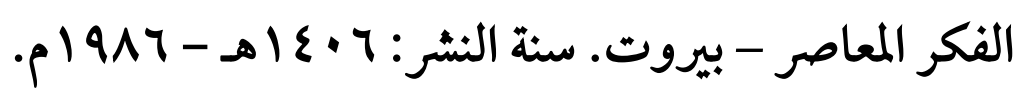




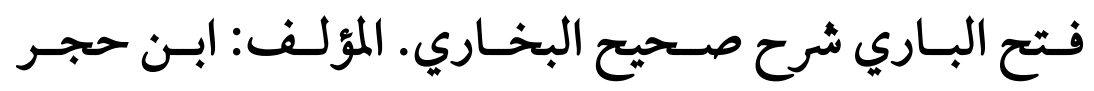

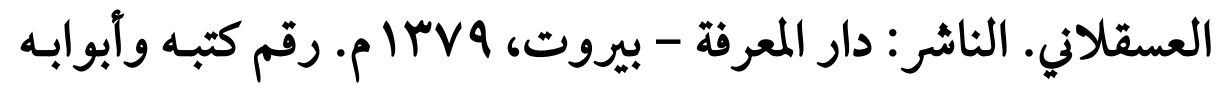

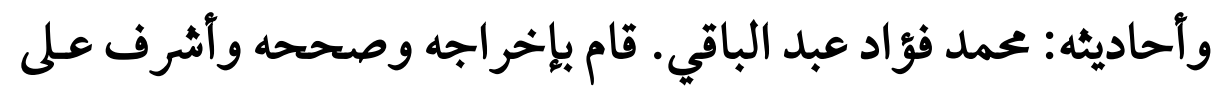

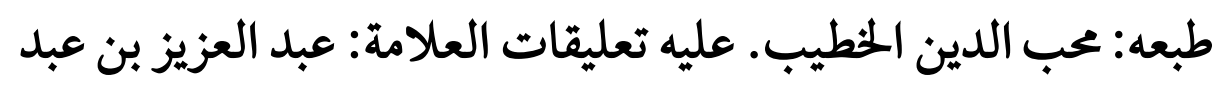

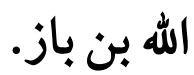

الكاشف في معرفة من له رواية في الكتب الستة. المؤلف: شمس

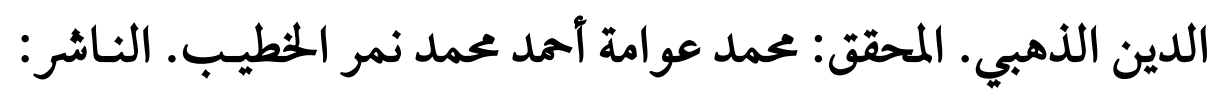

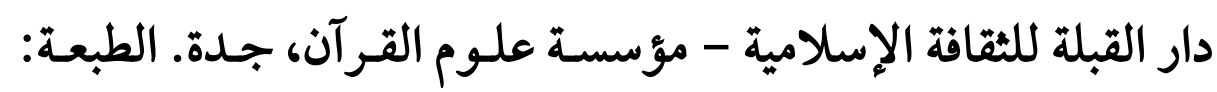

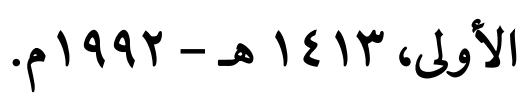

الكامل في ضعفاء الرجال. المؤلف: أبو أحمد بن عدي الجمان الجرجاني.

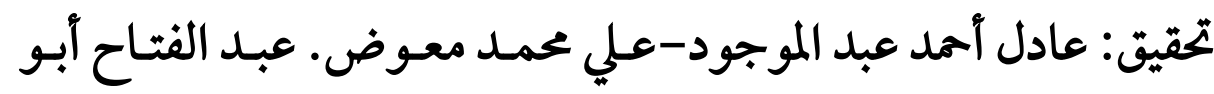

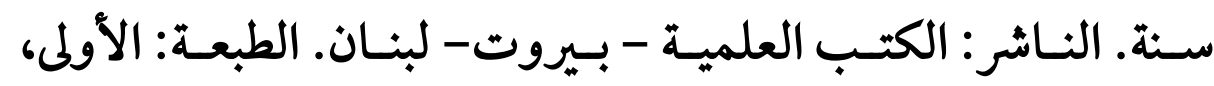
(1)

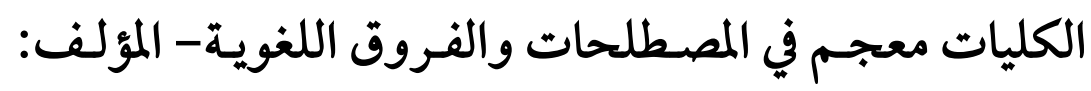
أيوب بن موسى الحسيني القريمي الكفوي، أبو البقاء الحنفي (المثوفى:

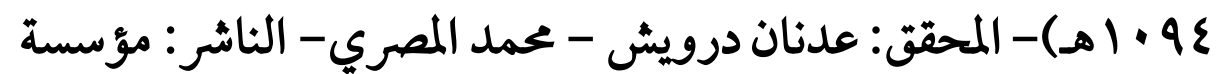

$$
\text { الرسالة - بيروت }
$$


الكواكب الثيرات في معرفة مـن الرواة الثقـات، المؤلف: أبـو

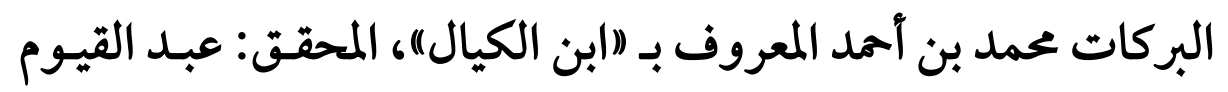

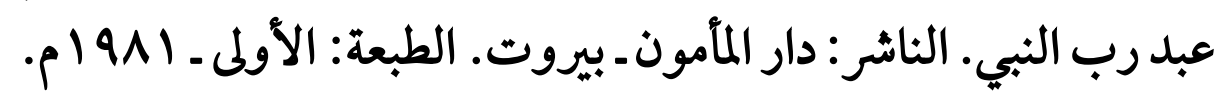

لسـان العـرب. المؤلف: جمـال الـدين ابـن منظـور الأنصـاري الماني

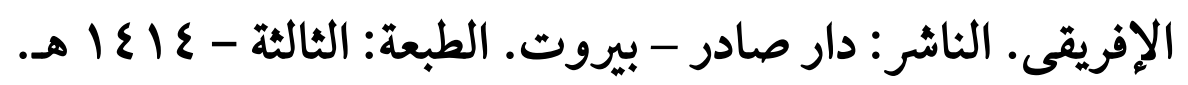

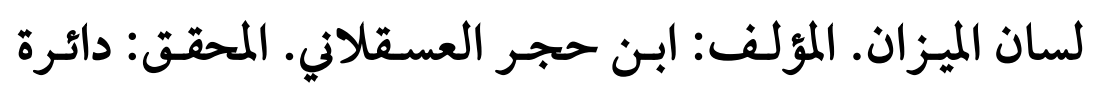

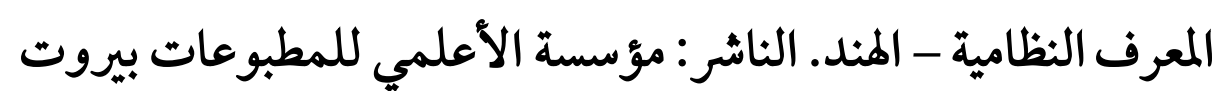

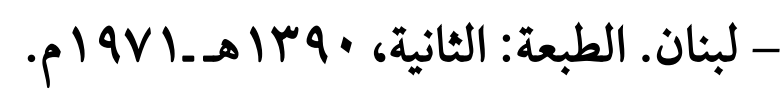

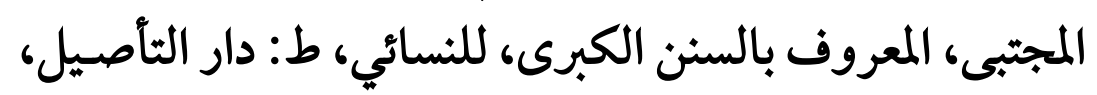

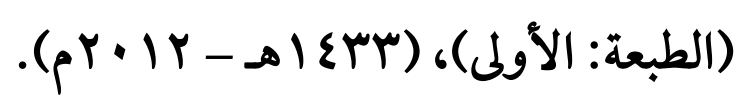

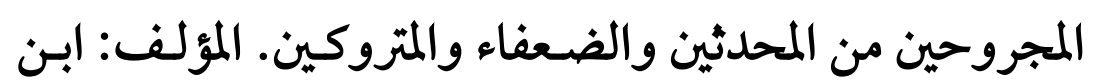

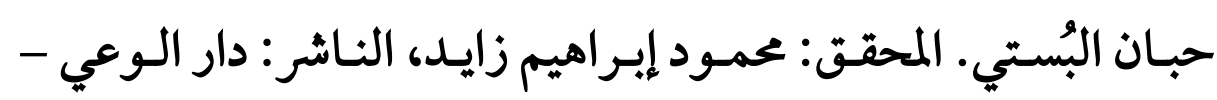

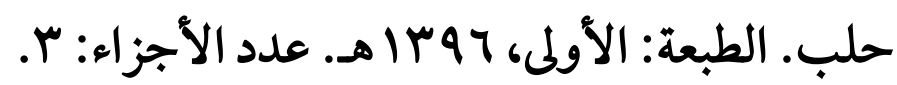

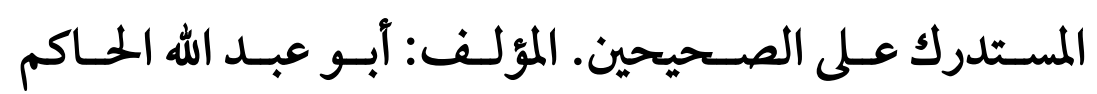

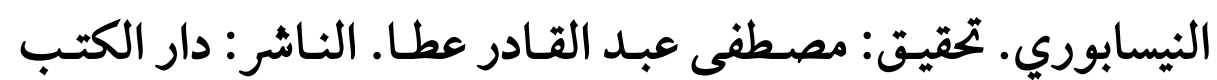

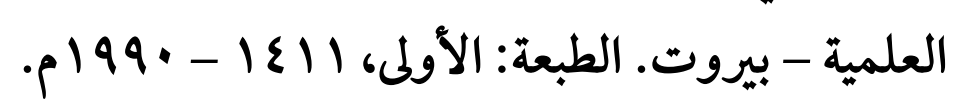

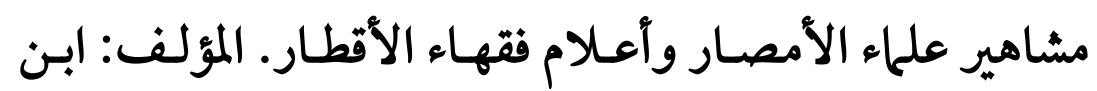

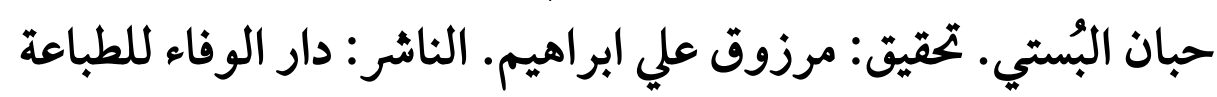

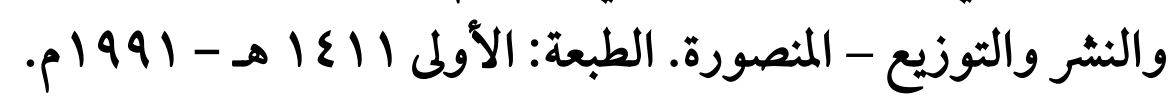


مشيخة النسائي، المؤلف: أبو عبد الرحمن أحمد بـن شعيب بـن علي النسائي. المحقق: الشريف حاتم بن عارف العوني. الناشر : دار عالم

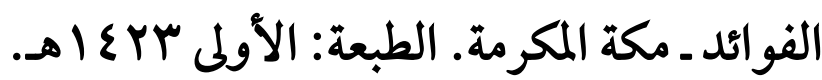

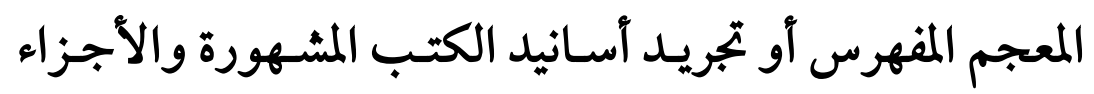
المنثورة، المؤلف: أبو الفضل أحمد بن علي بن حجر العسقلاني (المتوفى:

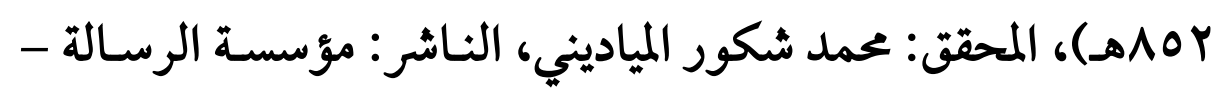

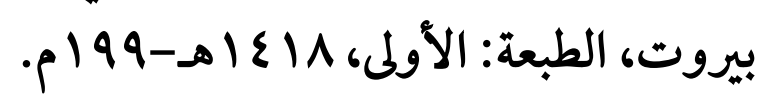
المعجم الوسيط. المؤلف: بجمع اللغة العربية بالقاهرة (إبراهيم

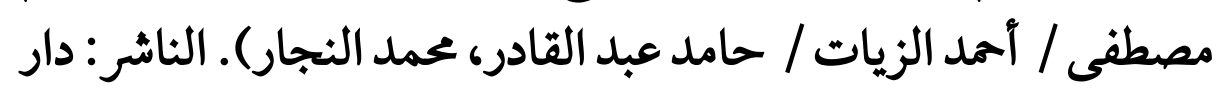

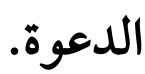
معرفة الثقات من رجال أهـل العلـم والحـديث ومـن الضـعفاء

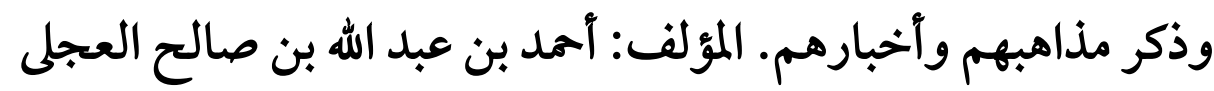
الكوفى. المحقق: عبد العليم عبد العظيم البستوي. الناشر : مكتبة الدار

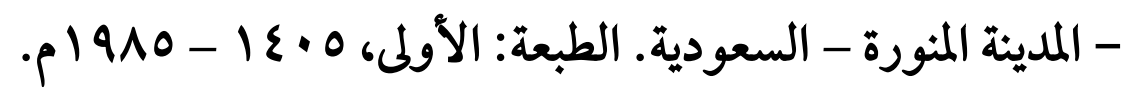

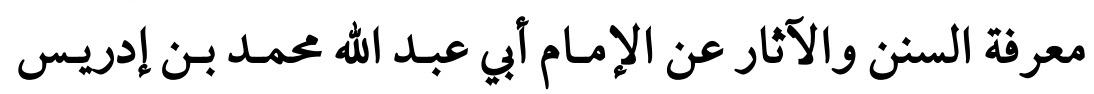

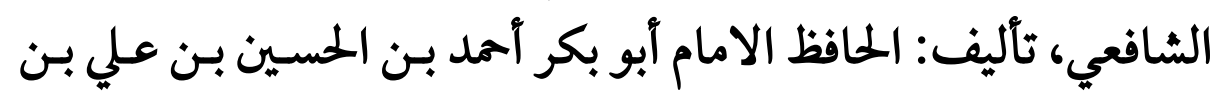

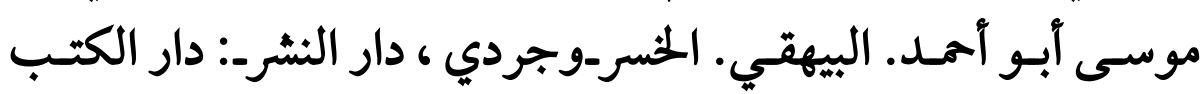

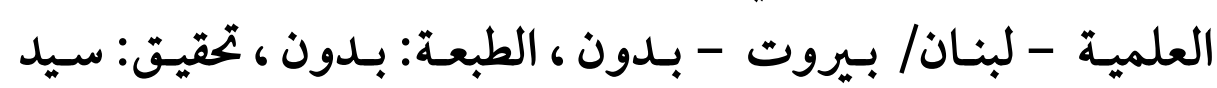
كسروي حسن. 
المغني في الضعفاء. المؤلف: شمس الدين الذهبي. المحققق:

$$
\text { الدكتور نور الدين عتر. }
$$

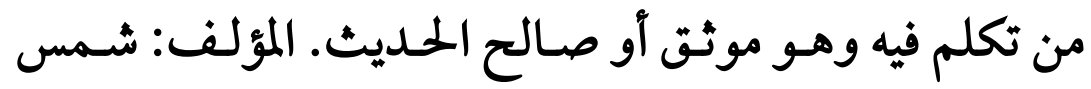
الدين الذهبي. المحقق: عبد الله بن ضيف الله الرحيلي. الطبعة: الأولي

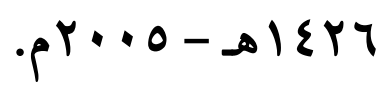

منهج العجلي في كتابه الثقات، لمحمد الرعود، بحث منشور في

$$
\text { المجلة الأردنية، كلية الدراسات الإسلامية. }
$$

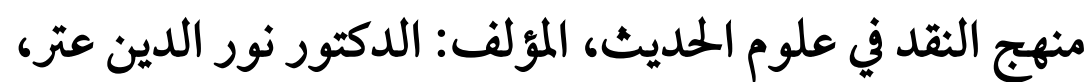

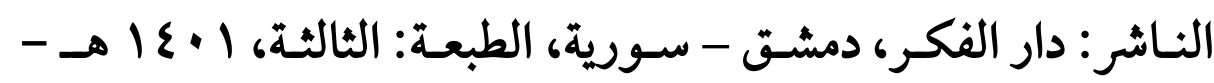

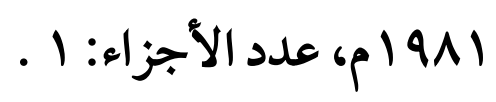

موسوعة أقوال أبي الحسن الدارقطني في رجال الحديث المديث وعلله.

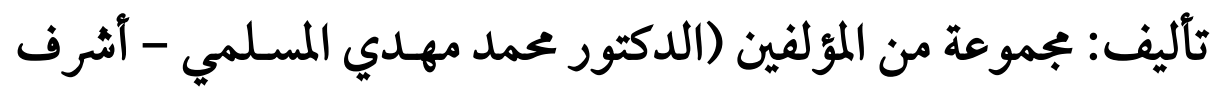

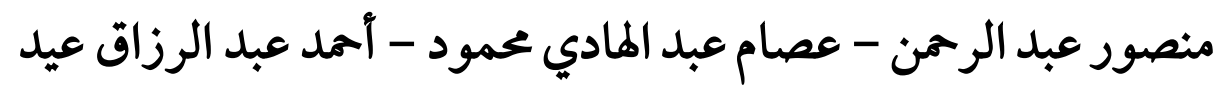

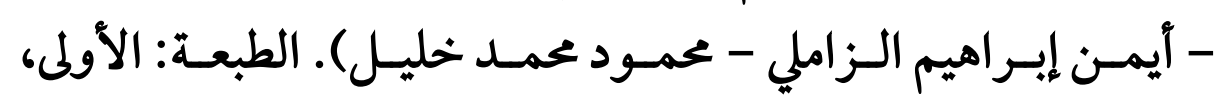

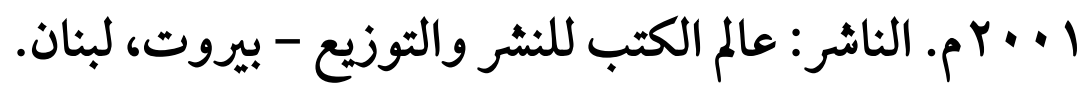

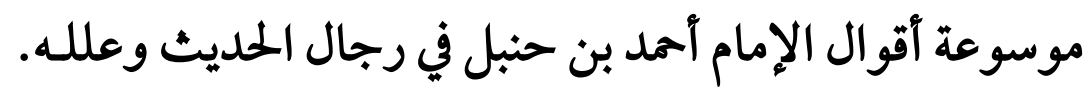

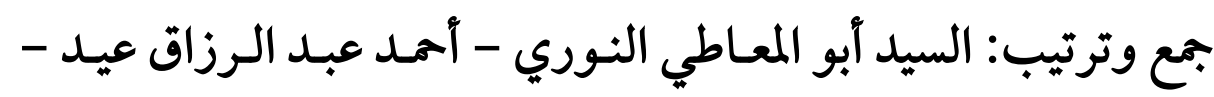

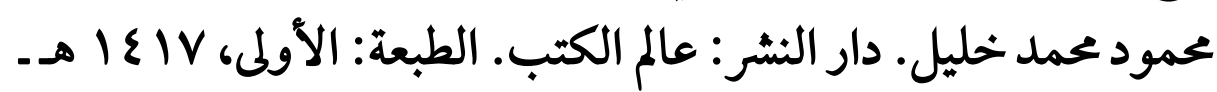


الموقظة في علم مصطلح الحديث، المؤلف: شمس الدين أبو عبد

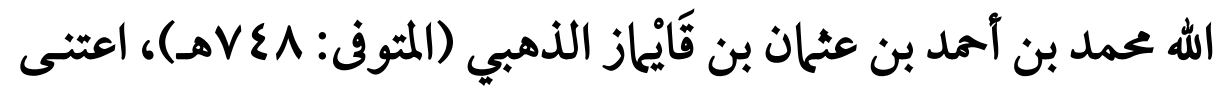

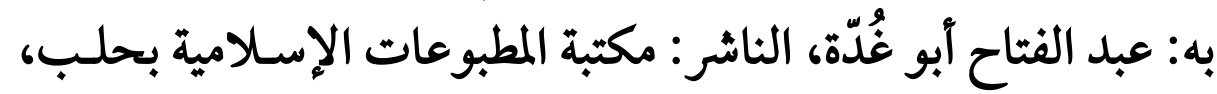

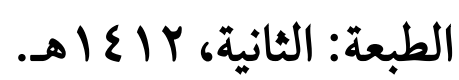
ميزان الاعتدال في نقد الرجال. المؤلف: شمس الدين الذهبي.

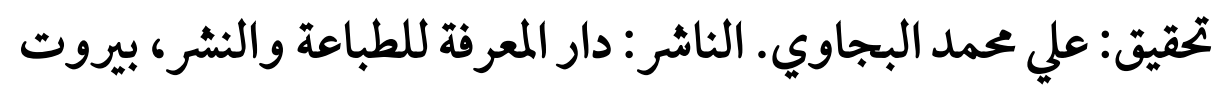

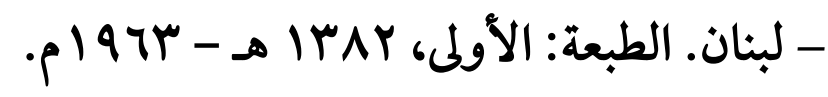

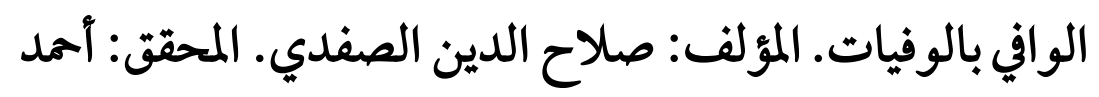

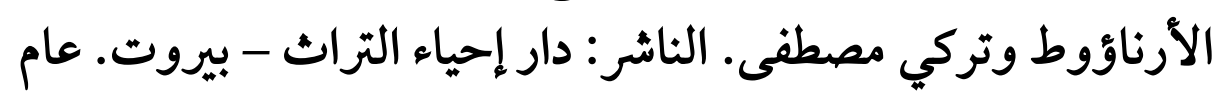

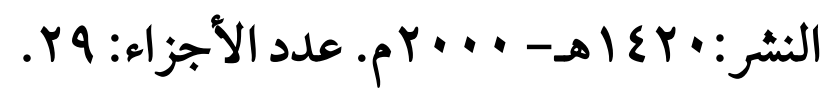


(117)

فهرس المحتويات

\begin{tabular}{|c|c|}
\hline الصفحة & 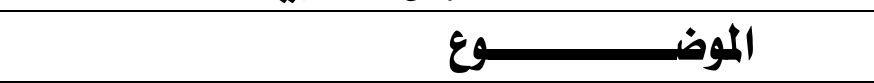 \\
\hline$\varepsilon$ & 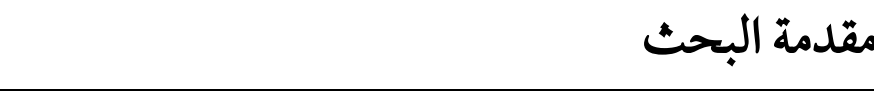 \\
\hline 0 & أهمية البحث ودوافع اختياره \\
\hline 0 & 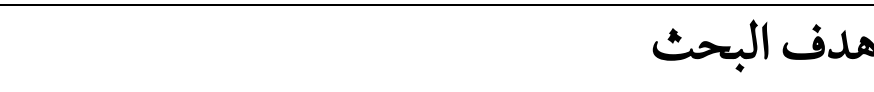 \\
\hline 7 & 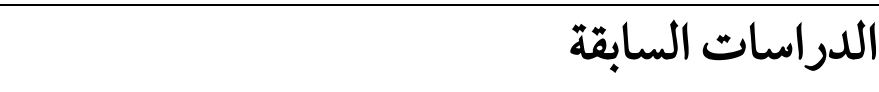 \\
\hline 7 & 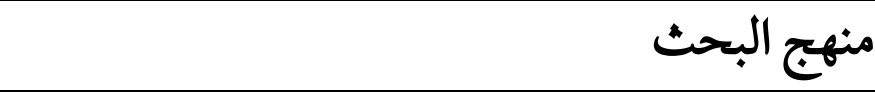 \\
\hline 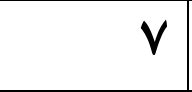 & خطة البحث \\
\hline 9 & التعريف بالإمام العجلي - رحمه الله \بايايجاز \\
\hline ir & التعريف بكتاب ((معرفة الثقات)، للإمام العجلي \\
\hline ir & تسميت القول في اسم الكتاب، وسبب الاختلاف في \\
\hline IV & 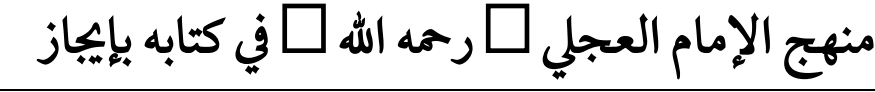 \\
\hline$r Y$ & تعريف مصطلح "(جائز الحديث)، ومدلوله، \\
\hline$r$. & الدراسة التطبيقية \\
\hline$r$. & 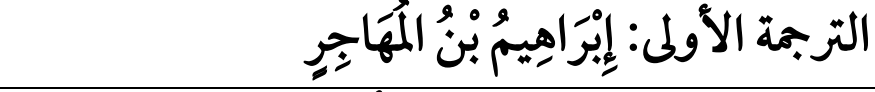 \\
\hline rV & الترجمة الثانية: إِسْرَرَائيل بن يُونُس \\
\hline$\varepsilon r$ & الترجمة الثالثة: حجاج بن أَزطًَاة \\
\hline
\end{tabular}


(IIV)

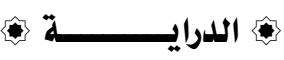

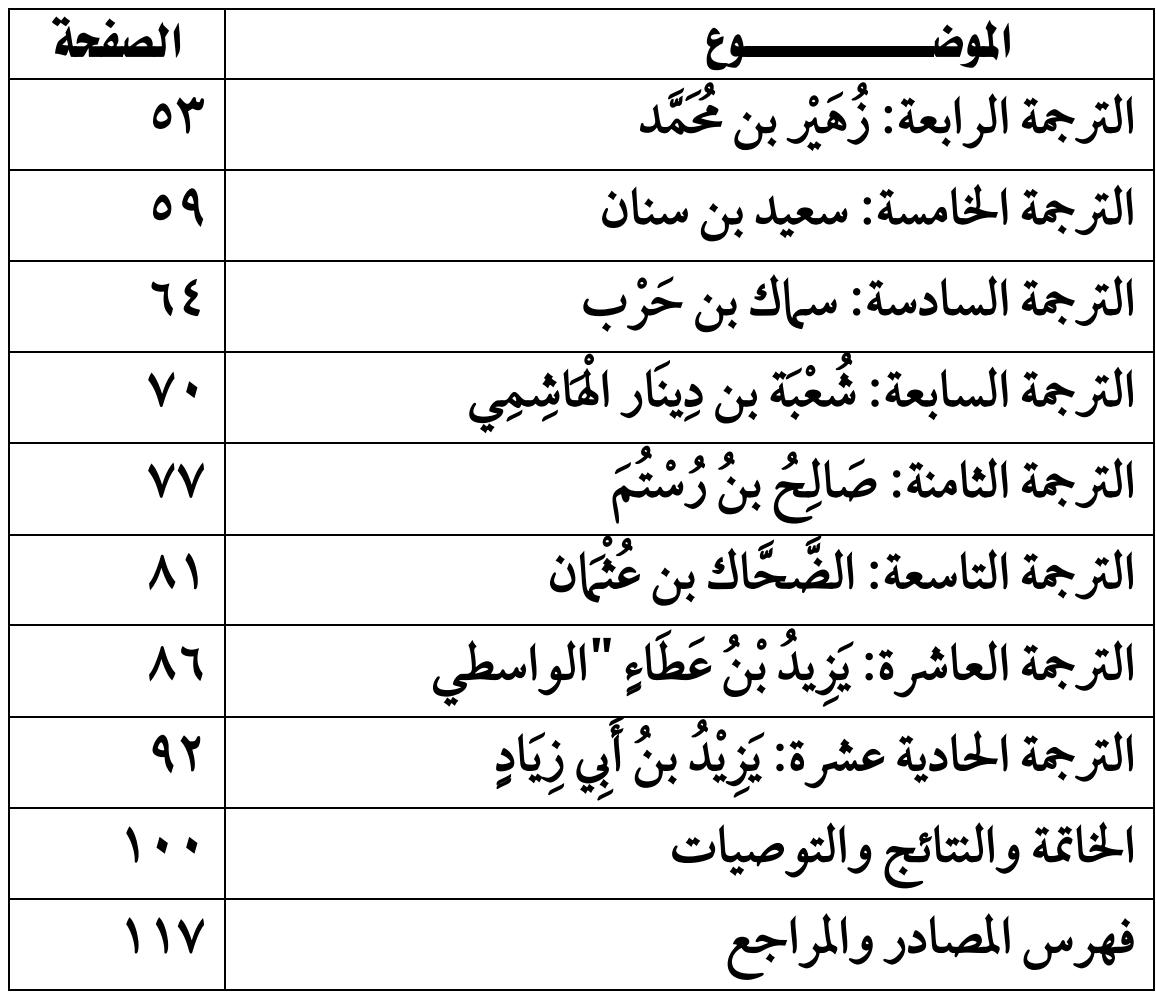

